\title{
Expedition 330 summary ${ }^{1}$
}

\author{
Expedition 330 Scientists $^{2}$
}

\section{Chapter contents}

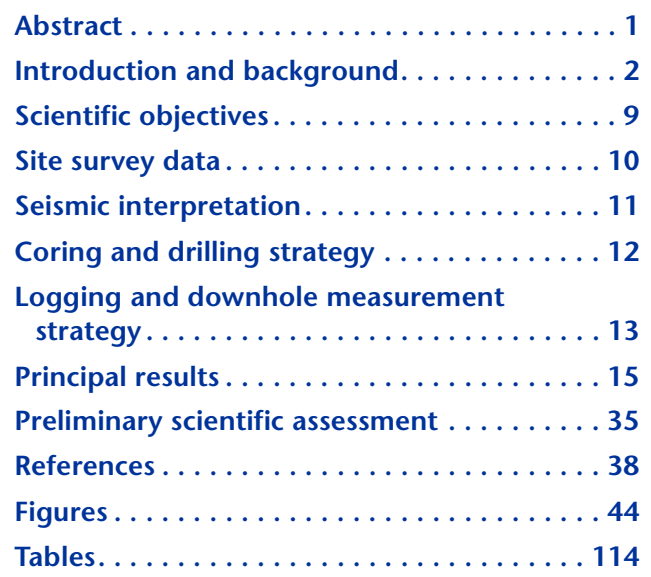

${ }^{1}$ Expedition 330 Scientists, 2012. Expedition 330 summary. In Koppers, A.A.P., Yamazaki, T., Geldmacher, J., and the Expedition 330 Scientists, Proc. IODP, 330: Tokyo (Integrated Ocean Drilling Program Management International, Inc.). doi:10.2204/iodp.proc.330.101.2012

'Expedition 330 Scientists' addresses.

\section{Abstract}

The Louisville Seamount Trail is a $4300 \mathrm{~km}$ long volcanic chain that has been built in the past $80 \mathrm{~m} . \mathrm{y}$. as the Pacific plate moved over a persistent mantle melting anomaly or hotspot. Because of its linear morphology and its long-lived age-progressive volcanism, Louisville is the South Pacific counterpart of the much better studied Hawaiian-Emperor Seamount Trail. Together, Louisville and Hawaii are textbook examples of two primary hotspots that have been keystones in deciphering the motion of the Pacific plate relative to a set of "fixed" deep-mantle plumes. However, drilling in the Emperor Seamounts during Deep Sea Drilling Project Leg 55 and Ocean Drilling Program Legs 145 and 197 documented a large $\sim 15^{\circ}$ southward motion of the Hawaiian hotspot prior to $\sim 50 \mathrm{Ma}$. Is it possible that the Hawaiian and Louisville hotspots moved in concert and thus constitute a moving reference frame for modeling plate motion in the Pacific? Alternatively, could they have moved independently, as predicted by mantle flow models that reproduce the observed latitudinal motion for Hawaii but that predict a largely longitudinal shift for the Louisville hotspot? These two end-member geodynamic models were tested during Integrated Ocean Drilling Program Expedition 330 to the Louisville Seamount Trail.

Existing data from dredged lava suggest that the mantle plume source of the Louisville hotspot has been remarkably homogeneous for as long as $80 \mathrm{~m}$.y. This lava is composed of predominantly alkalic basalt and likely represents a mostly alkalic shieldbuilding stage, which contrasts sharply with the massive tholeiitic shield-building stage of Hawaiian volcanoes. Geochemical and isotopic data for core samples recovered during Expedition 330 will provide insights into the magmatic evolution and melting processes of individual Louisville volcanoes, their progression from shield-building to postshield and perhaps posterosional stages, the temperature and depth of partial melting of their mantle plume source, and the enigmatic long-lived and apparent geochemical homogeneity of the Louisville mantle source. Collectively, this will enable us to characterize the Louisville Seamount Trail as a product of one of the few global primary hotspots, to better constrain its plume-lithosphere interactions, and to further test the hypothesis that the Ontong Java Plateau formed from the plume head of the Louisville mantle plume around $120 \mathrm{Ma}$. 
The drilling strategy of Expedition 330 replicated that of Leg 197, the first expedition to provide compelling evidence for the motion of the Hawaiian mantle plume between $\sim 80$ and $50 \mathrm{Ma}$. For that reason drilling targeted seamounts in the Louisville Seamount Trail equivalent in age to Detroit, Suiko, Nintoku, and Koko Seamounts in the Hawaiian-Emperor Seamount Trail. In total, six sites were drilled on five seamounts: Canopus, Rigil, Burton, Achernar, and Hadar Guyots (from oldest to youngest). Analysis of a large number of time-independent in situ lava flows (and other volcanic eruptive products) from these seamounts using modern paleomagnetic, ${ }^{40} \mathrm{Ar} /{ }^{39} \mathrm{Ar}$ geochronological, and geochemical techniques will allow direct comparison of the paleolatitude estimates and geochemical signatures of the two longest-lived hotspot systems in the Pacific Ocean.

In all cases, the summits of the flat-topped seamounts (i.e., guyots) were drilled, and volcanic basement was reached at four of these drilling targets. In two cases larger seamount structures were targeted and drilled near their flanks; in the other three cases smaller edifices were selected and drilled closer to their centers. Drilling and logging plans for each of these sites were similar, with coring reaching 522.0 meters below seafloor (mbsf) for Site U1374 and 232.9, 65.7, 11.5, 182.8, and $53.3 \mathrm{mbsf}$ for Sites U1372, U1373, U1375, U1376, and U1377, respectively. Some Expedition 330 drill sites were capped with a thin layer of pelagic ooze between 6.6 and $13.5 \mathrm{~m}$ thick, which was cored using a gravity-push approach with little or no rotation of the rotary core barrel assembly to maximize recovery. However, at Sites U1373 and U1376 no pelagic ooze was present, and the holes needed to be started directly into cobble-rich hardgrounds. In all cases, the bulk of the seamount sedimentary cover comprised sequences of volcanic sandstone and various kinds of basalt breccia or basalt conglomerate that often were interspersed with basaltic lava flows, the spatter/tephra products of submarine eruptions, or other volcanic products, including autobrecciated lava flows or peperites. Also, several intervals of carbonate were cored, with the particularly interesting occurrence of a $\sim 15 \mathrm{~m}$ thick algal limestone reef at Site U1376 on Burton Guyot. In addition, some condensed pelagic limestone units were recovered on three of the other seamounts, but these did not exceed $30 \mathrm{~cm}$ in thickness. Despite limited presence in the drilled sediments, these limestone occurrences provide valuable insights for the paleoclimate record at high $\sim 50^{\circ}$ southern latitudes since the Cretaceous.

Several Louisville sites progressed from submarine to subaerial eruptive environments at the top of the volcanic basement. However, at Sites U1376 and U1377 on Burton and Hadar Guyots, igneous base- ment immediately began with submarine volcanic sequences. More than $100 \mathrm{~m}$ of igneous basement was cored at three sites: $187.3 \mathrm{~m}$ at Site U1372, 505.3 $\mathrm{m}$ at Site U1374, and $140.9 \mathrm{~m}$ at Site U1376. At the other sites basement was not cored (Site U1375) or recovery was limited to only $38.2 \mathrm{~m}$ (Site U1377) because of unstable hole conditions. Even so, drilling during Expedition 330 resulted in a large number of in situ lava flows, pillow basalts, or other types of volcanic products such as autobrecciated lava flows, intrusive sheets or dikes, and peperites. In particular, the three holes on Canopus and Rigil Guyots, with probable eruption ages estimated at $\sim 75-77$ and 73 $\mathrm{Ma}$, respectively, likely have adequate numbers of in situ lava flows to average out paleosecular variations of the geomagnetic field. Remarkably, at all drill sites large quantities of hyaloclastites, volcanic sandstone, and basaltic breccia were also recovered, and in many cases these show consistent paleomagnetic inclinations compared to the intercalated lava flows. In the cored sequence for Site U1374 on Rigil Guyot both normal and reversed polarity was documented. Overall, the cored basement sequences are very promising for determining a reliable paleolatitude record for the Louisville Seamounts following detailed postexpedition examinations.

Deeper penetrations of several hundred meters required bit changes and reentries using free-fall funnels. Basement penetration rates were $1.8-2.5 \mathrm{~m} / \mathrm{h}$ depending on drill depth. In total, $1114 \mathrm{~m}$ of sediment and igneous basement was drilled at five seamounts, with an average recovery of $72.4 \%$. At Site U1374 on Rigil Guyot, a total of $522 \mathrm{~m}$ was drilled, with a record-breaking $87.8 \%$ recovery. Importantly, a significant proportion of Expedition 330 core material is characterized by low degrees of alteration, providing a large quantity of samples of mostly wellpreserved basalt containing, for example, pristine olivine crystals with melt inclusions, fresh volcanic glass, unaltered plagioclase, carbonate, various micro- and macrofossils, and in one case mantle xenoliths and xenocrysts. The large quantity and excellent quality of the recovered sample material will allow all of the scientific objectives of this expedition to be addressed.

\section{Introduction and background}

Understanding the nature of mantle plumes is a critical goal of modern Earth sciences. The extent to which hotspots conform to the Wilson-Morgan fixed plume hypothesis (Wilson, 1963; Morgan, 1971) fundamentally constrains the assumptions used in models of mantle convection. To date, studies of the Hawaiian-Emperor Seamount Trail have dominated our thinking about hotspot volcanism, and as a con- 
sequence models for the construction and evolution of intraplate volcanoes, plate motion, and hotspot motion are strongly biased toward the Hawaiian hotspot. Without comparable data from any other important Pacific hotspot trail, many key questions remain unanswered. The Louisville Seamount Trail (Fig. F1) is the product of one of only three primary hotspots in the Pacific (together with Hawaii and Easter; Courtillot et al., 2003) and has great potential for providing these answers. New results from Integrated Ocean Drilling Program (IODP) drilling of the Louisville Seamount Trail during Expedition 330, together with existing data and future drilling of other hotspot trails in the Atlantic and Indian Oceans, will provide the best available opportunity to assess the importance of the motion between hotspots (or groups of hotspots) and true polar wander. These data, in turn, will provide some of the most valuable information on Earth's convection regime and a crucial calibration of current mantle flow models and global plate circuit reconstructions.

Hotspots and the (deep) mantle plumes that are presumed to be their underlying cause (e.g., Morgan, 1971) are essential features in contemporary geodynamic models of the Earth's mantle. One of the attributes frequently assigned to mantle plumes is fixity in the mantle. This fixity contrasts sharply with the motion rates of the overlying plates, which can be as high as $100 \mathrm{~mm} / \mathrm{y}$. However, plume theory does not demand fixity (e.g., Steinberger and O'Connell, 1998; Koppers et al., 2001), and paleomagnetic evidence collected during Ocean Drilling Program (ODP) Legs 145 and 197 at Detroit, Suiko, Nintoku, and Koko Seamounts in the Emperor Seamount Trail indicates that the Hawaiian hotspot has moved at a speed similar to that of plate motion for tens of millions of years (Kono, 1980; Petronotis et al., 1994; Tarduno and Cottrell, 1997; Tarduno et al., 2003, 2009; Duncan et al., 2006). Three-dimensional mantle convection computations confirm this notion by generating mantle plumes with long, narrow thermal conduits that are anchored (deep) in the mantle (Davies and Davies, 2009) but that may migrate at rates of $10 \mathrm{~mm} / \mathrm{y}$ and higher, primarily depending on the assumed viscosity contrast between the lower and upper mantle and the configuration of the subducting plates (Lowman et al., 2004).

These observations raise critical questions. Is the rapid motion documented for the Hawaiian hotspot an isolated event or does it happen to other hotspots as well? If so, do these hotspots move in a sufficiently coherent fashion that subsets can be used as a moving reference frame for reconstructing past plate motion? To address these questions we must distinguish between the following geodynamic end-member models:
1. The three primary hotspots in the Pacific (Hawaii, Louisville, and Easter) have moved coherently over geological time and thus show minimal interhotspot motion (Wessel and Kroenke, 1997; Courtillot et al., 2003).

2 . These primary hotspots show very different patterns of motion, resulting in increased interhotspot motion, as predicted by mantle flow model calculations (Steinberger, 2002; Steinberger et al., 2004; Koppers et al., 2004; Steinberger and Antretter, 2006; Steinberger and Calderwood, 2006).

The first model predicts that the motion of the Louisville hotspot should be equivalent to the $15^{\circ}$ of southern motion documented for the Hawaiian hotspot between 80 and $50 \mathrm{Ma}$. The second model predicts an essentially eastward motion for the Louisville hotspot over the last 120 m.y., with a maximum shift in paleolatitude not exceeding $6^{\circ}$ between $80 \mathrm{Ma}$ and the present day, depending on various assumptions used in the mantle flow models (Fig. F2). Both models can be tested by drilling the Louisville Seamount Trail and accurately determining the paleolatitudes (from detailed paleomagnetic measurements on individual lava flows) and ${ }^{40} \mathrm{Ar} /{ }^{39} \mathrm{Ar}$ age dates for a small number of seamounts between 80 and $50 \mathrm{Ma}$. For this purpose Expedition 330 provided a direct comparative test by mimicking Leg 197 drilling in the Emperor Seamounts as closely as possible (Tarduno et al., 2003; Duncan and Keller, 2004; Duncan et al., 2006, 2007), targeting guyots equivalent in age to Detroit (76-81 Ma), Suiko (61 $\mathrm{Ma})$, Nintoku (56 Ma), and Koko (49 Ma) Seamounts (Fig. F1).

Although determining paleolatitudes in the context of a high-resolution ${ }^{40} \mathrm{Ar} /{ }^{39} \mathrm{Ar}$ age framework was the main objective of Expedition 330, this project also afforded the opportunity to constrain the eruptive cycle and geochemical evolution of typical Louisville volcanoes. The Hawaiian and Louisville hotspots have been labeled as primary hotspots in the Pacific on the basis of obvious linear age progressions, longlived and continuous volcanism, large buoyancy fluxes, and high (in the case of Hawaii) ${ }^{3} \mathrm{He} /{ }^{4} \mathrm{He}$ ratios (Courtillot et al., 2003; Koppers et al., 2003). Such hotspots are theorized to represent the locales at which plumes are rising from deep in the mantle, perhaps from near the core/mantle boundary (Clouard and Bonneville, 2001; Davaille et al., 2002; Courtillot et al., 2003). Unlike earlier studies that postulated many (or even all) hotspots represent plumes originating from the core/mantle boundary, Courtillot et al. (2003) have argued that most hotspots arise from relatively shallow levels and that only a small number of primary plumes ascend from the core/mantle boundary. Nonetheless, among the 
primary hotspots of the Pacific Ocean, some marked differences in geochemistry and volcanic evolution are apparent. For example, the near-exclusive recovery of alkalic basalt in the Louisville Seamount Trail (Hawkins et al., 1987; Vanderkluysen et al., 2007; Beier et al., 2011) raises the question of whether Louisville volcanoes have an alkalic shield-building phase instead of the tholeiitic shield-building phase that is a trademark of Hawaiian volcanoes. One possibility is that the shield stage of a Louisville volcano reflects systematically lesser amounts of partial melting than in the Hawaiian case, caused by deeper melting under a uniformly thicker lithosphere. In addition, isotopic and trace element data from Louisville suggest a long-lived and remarkably homogeneous mantle source (Cheng et al., 1987; Hawkins et al., 1987; Vanderkluysen et al., 2007; Beier et al., 2011). If these volcanoes have entirely alkalic shieldbuilding phases that are isotopically homogeneous over $80 \mathrm{~m} . \mathrm{y}$. of volcanic activity, this has major implications for how we think volcanism works for the Louisville hotspot and intraplate volcanism in general.

\section{Mantle geodynamics and hotspot motion}

Recently, it has been proposed that plume conduits may become strongly tilted at times because of largescale mantle flow (e.g., Steinberger and O'Connell, 1998), which possibly may explain the fast southward hotspot motion observed for the Hawaiian hotspot ( 40 mm/y) between 80 and $50 \mathrm{Ma}$ (Tarduno et al., 2003). Such strong tilts may happen if the conduit is affected by a lower mantle return flow between cold downwellings associated with subduction and large-scale upwellings in the neighborhood of "superplumes." Alternatively, the capturing, bending, and releasing of the Hawaiian mantle plume by an ancient ridge system may also explain these observations (Tarduno et al., 2009). For the Hawaiian hotspot, all of these ingredients are present-a zone of past subduction to the north, a large-scale upwelling related to the Superswell to the south (Tarduno et al., 2003), and the waning of the Kula-Pacific ridge system to the north of the hotspot-allowing a possibly captured Hawaiian plume to quickly return to its original straight position in a dominantly southward flow (Tarduno et al., 2009). However, because the Louisville hotspot lies south of the Superswell, the closest subduction system has always been located to its west, and no spreading center has been located north and in close proximity for most of its geological history, this pattern is not compatible with a similar rapid southward motion for the Louisville hotspot.
Modeling by Steinberger et al. (2004) shows the expected results of this configuration, whereby the Hawaiian hotspot indeed moves $15^{\circ}$ south from 80 to $50 \mathrm{Ma}$, but the Louisville hotspot moves primarily in an easterly direction between 130 and $60 \mathrm{Ma}$, and only $\sim 2.5^{\circ}$ south since $60 \mathrm{Ma}$ (Fig. F2A). In these models a large-scale mantle flow field is first calculated from mantle density heterogeneities (as derived from seismic $S$-wave speed anomalies) by applying a radial mantle rheology structure (with a lower mantle assumed to be more viscous) and by using tectonic plate motions as boundary conditions (Steinberger and O'Connell, 2000; Steinberger and Calderwood, 2006). Within the modeled mantle flow field, a vertical plume conduit is inserted that gets advected over time, resulting in the sometimes strong tilting of mantle plumes and the drifting of hotspots (Steinberger and O'Connell, 2000; Steinberger and Antretter, 2006). Advection dominates the motion of a plume at depths where it rises relatively slowly in comparison to the overall mantle flow field, typically in the lower mantle. As a result, hotspot motion seems in many cases (including Louisville) to be similar to the predicted horizontal flow in the mid-mantle, at which depth the transition occurs from motion dominated by advection in the lower mantle to a more vertical motion dominated by the buoyant rising of the mantle plumes in the upper mantle (Steinberger, 2000). These characteristics remain the same regardless of whether mantle plumes originate at the core/mantle or $670 \mathrm{~km}$ boundary layers. In spite of the large uncertainties in the data and the assumptions on which they are built, these mantle flow models provide an excellent basis for placing the geological data derived from Louisville and other seamount trails into a more complex geodynamic context.

Mantle flow models using the modeling approach of Steinberger et al. (2004) thus show a largely eastward motion for the Louisville hotspot, which is very different from the $\sim 15^{\circ}$ southward motion for Hawaii during the same time interval. This longitudinal motion for the Louisville hotspot is followed by only a minor latitudinal shift over the last 60 m.y. (Fig. F2B, Model 5 in Fig. F2C). These models, however, show large variations in their predictions depending on the assumptions made, such as plume initiation age, root depth, viscosity structure, plume buoyancy, plume rising speed, plate motion history, and mantle viscosity. Antretter et al. (2004) and Steinberger and Antretter (2006) have considered the possible effects of these assumptions in more detail for the Louisville hotspot and predict paleolatitude shifts between almost none and $\sim 8^{\circ}$ to the south, as integrated over 
the last $80 \mathrm{Ma}$. However, the majority of their model runs (see Fig. F2C for six representative examples) show a latitudinal motion for Louisville that is significantly less than that observed for Hawaii. Also, for models that show a faster Louisville hotspot motion, the increased motion is always more eastward, in a direction away from the subduction zone and toward the spreading ridge.

Paleolatitude shifts of Pacific hotspots also can be estimated by transferring plate motion from IndoAtlantic hotspots to the Pacific plate using global plate circuits, assuming fixity of Indo-Atlantic hotspots. For example, Doubrovine and Tarduno (2008a, 2008b) showed that the Late Cretaceous to Paleogene apparent polar wander path transferred from the paleomagnetic data of the Atlantic-bordering continents to the Pacific plate is consistent with the $\sim 15^{\circ}$ paleolatitude shift observed in the Hawaiian-Emperor Seamount Trail. Shifts in paleolatitude of the Louisville hotspot can be predicted by the same approach (Fig. F3), although a large uncertainty still remains in the global plate circuit, which may go through East and West Antarctica (Cande et al., 1995) or, alternatively, through the Lord Howe Rise (Steinberger et al., 2004). Also critical is the current location of the Louisville hotspot, which still is a matter of debate because of its faint expression at the younger end of this seamount trail (Lonsdale, 1988; Raymond et al., 2000; Wessel and Kroenke, 1997; Koppers et al., 2011). All plate reconstructions (using different combinations of plate circuits and present-day hotspot locations) yield predictions that become significantly different from the position of the Louisville Seamount Trail prior to 45 Ma (Fig. F3). As with mantle flow models, a large longitudinal shift is apparent at $78 \mathrm{Ma}$ when comparing the oldest seamounts in the trail to the reconstructed position for Chron C33, which all plot markedly west of the Louisville Seamount Trail. It is interesting to note that the predicted potential southward shift in these plate tectonic reconstructions seems less pronounced for the oldest seamounts $\left(3.8^{\circ}\right.$ and $4.0^{\circ}$, depending on the plate circuit used), is largest for the $\sim 53 \mathrm{Ma}$ seamounts $\left(8.9^{\circ}\right.$ and $9.8^{\circ}$, which actually indicates a possible $4^{\circ}-5^{\circ}$ northward motion of the plume between 80 and $50 \mathrm{Ma}$ ), and is nonexistent for seamounts younger than $\sim 45 \mathrm{Ma}$.

The above geodynamic and plate tectonic models thus provide different predictions for the latitudinal (and longitudinal) history of the Louisville hotspot. These models were ground truthed during IODP Expedition 330, which should allow us to distinguish between the following possibilities:

1. The Louisville hotspot shows a pronounced southward motion (up to $15^{\circ}$ ) that is comparable to the southward motion of the Hawaiian hotspot from 80 to $50 \mathrm{Ma}$, providing evidence for a common motion of the mantle underlying the Pacific plate with respect to Earth's spin axis;

2. The Louisville hotspot shows an insignificant cumulative latitudinal shift $\left(<2^{\circ}-6^{\circ}\right)$, supporting the Steinberger et al. (2004) mantle flow models that predict minimal latitudinal motion and a pronounced easterly longitudinal motion; or

3. The Louisville hotspot shows a variable latitudinal motion between 80 and $50 \mathrm{Ma}$ in combination with a large longitudinal shift (that we cannot constrain), reconciling the observations made with global plate circuit models.

By comparing paleolatitudes from the paleomagnetic measurements on cored basalt flows and high-precision ${ }^{40} \mathrm{Ar} /{ }^{39} \mathrm{Ar}$ ages for the Hawaiian and Louisville Seamount Trails, drilling results from Expedition 330 will offer strong constraints for one of these possibilities. Finding a large latitudinal shift between 80 and $50 \mathrm{Ma}$ clearly would indicate that current assumptions in the mantle flow models are wrong. Finding no appreciable shift, on the other hand, would indicate significant interhotspot motion between the Hawaiian and Louisville hotspots and a stronger local control on the mantle flow regime.

Paleolatitude measurements of the Louisville Seamount Trail can also be used for comparisons of interocean motion between hotspots in the Pacific, Indian, and Atlantic Oceans. In previous studies, large discrepancies of up to $20^{\circ}$ in motion have been reported between hotspot groups in the Pacific and Atlantic/Indian Oceans (Cande et al., 1995; DiVenere and Kent, 1999; Raymond et al., 2000). These observations have led to models of large-scale motion of the mantle underneath each ocean or to explanations involving true polar wander, which is defined as a coherent shift of the entire mantle relative to the spin axis (Goldreich and Toomre, 1969; Gordon, 1987; Besse and Courtillot, 1991, 2002; Torsvik et al., 2002). Drilling of the Louisville Seamount Trail helped to expand the necessary global paleolatitude and ${ }^{40} \mathrm{Ar} /{ }^{39} \mathrm{Ar}$ age databases needed to evaluate the above scenarios. In fact, Expedition 330 will allow us to determine paleolatitude data for a time interval similar to that sampled in the Emperor Seamount Trail during Leg 197 and earlier expeditions (Kono, 1980; Tarduno et al., 2003), and future ocean drilling expeditions to the Chagos-Laccadive and Ninetyeast Ridges in the Indian Ocean and Walvis Ridge in the Atlantic Ocean may refine the existing paleolatitude record for other volcanic chains. These expeditions may provide a state-of-the-art paleolatitude database covering five major hotspot trails in three oceans, all between 80 and $50 \mathrm{Ma}$ in age. At that point it will be 
clear whether the observed paleolatitude shifts in hotspots are best explained by coherent motion of all hotspots, by coherent motion of hotspot groups within each ocean domain (but with relative motion between these groups), by incoherent motion of all individual hotspots, or by true polar wander.

\section{Age relations along the Louisville Seamount Trail}

Using high-resolution ${ }^{40} \mathrm{Ar} /{ }^{39} \mathrm{Ar}$ age data, Koppers et al. (2004) found that the age progression for the Louisville Seamount Trail is overall nonlinear (blue squares in Fig. F4A). Site survey ${ }^{40} \mathrm{Ar} /{ }^{39} \mathrm{Ar}$ age data from the SO167 and AMAT02RR expeditions underline the nonlinear character of the Louisville age progression (Fig. F4A), yet they also show a very systematic age-progressive trend from $\sim 20$ to $80 \mathrm{Ma}$ (Koppers et al., 2011). Deviations from earlier reported ages and a hypothesized $64 \mathrm{~mm} / \mathrm{y}$ linear age progression (Watts et al., 1988) become noticeable around $35 \mathrm{Ma}$ and are most significant toward the old end of the trail, where some guyots are now dated $\sim 15$ m.y. older than previously reported (Koppers et al., 2004). For now, the age progression for the Louisville Seamount Trail seems best approximated by the purple line in Fig. F4A, which simply envelops the oldest ages and follows the model of Koppers et al. (2004). Interestingly, new age information from the SO167 dredges reveals a more complex age distribution in the older portion of the Louisville Seamount Trail, with some seamounts showing ages considerably younger than the age-progressive volcanism, which is the first evidence of late-stage or rejuvenated volcanic activity for this trail ( $\mathrm{O}^{\prime}$ Connor et al., submitted). Understanding the evolution of a typical Louisville seamount through state-of-the-art ${ }^{40} \mathrm{Ar} /{ }^{39} \mathrm{Ar}$ age dating (Fig. F4B) therefore will be crucial in evaluating models predicting relative motion between hotspots. For example, Wessel and Kroenke (2009) examined the temporal variations in the geographical separation between the Louisville and Hawaiian hotspots, as measured by any change in their great-circle distance over time. By considering both the geometry and the ${ }^{40} \mathrm{Ar} /{ }^{39} \mathrm{Ar}$ ages of the seamounts constituting these two primary seamount trails, they concluded that the Louisville hotspot may have moved several degrees to the south relative to Hawaii before $\sim 55$ Ma because congruent seamounts in both trails formed at a larger great-circle distance from each other during that time. However, they also showed that the Louisville and Hawaiian hotspots kept a very constant separation after that episode of interhotspot motion. Between $55 \mathrm{Ma}$ and the present day, both hotspot systems seemingly have been moving in tandem, or more likely have been stationary, without any significant interhotspot motion for a prolonged period of time.

The age, and hence lithospheric thickness, of the seafloor at the time of seamount formation in the Louisville Seamount Trail is poorly constrained for seamounts west of the Wishbone Scarp. Early studies suggested that Louisville volcanoes generally erupted onto seafloor that was $\sim 40-50$ Ma (Lonsdale, 1988; Watts et al., 1988; Lyons et al., 2000). These estimates are best constrained east of the Wishbone Scarp, where magnetic anomalies provide crustal ages. Watts et al. (1988) noted a smaller effective elastic thickness, and thus a smaller age difference, for seamounts west of the Wishbone Scarp. A recent seismic refraction study of the oceanic lithosphere beneath the $27.6^{\circ} \mathrm{S}$ Guyot ( 1.1 ${ }^{\circ}$ south of Site U1372; Fig. F5) delineates flexure of the Mohorovicic seismic discontinuity $(\mathrm{MOHO})$, which has been interpreted as reflecting volcano growth on $\sim 10$ m.y. old lithosphere (Contreras-Reyes et al., 2010). This smaller age difference appears generally consistent with the age of Osbourn Guyot (76-79 Ma) and its distance from the Osbourn Trough paleospreading center. The age at which spreading at the Osbourn Trough ceased is not well constrained because it occurred within Chron C34 (a 37 m.y. long interval of normal polarity), but recent estimates suggest that spreading may have continued until between $~ 86$ and $\sim 93$ Ma (Downey et al., 2007; Worthington et al., 2006). Thus, the oldest seamounts in the Louisville Seamount Trail may have formed on relatively young, thin lithosphere.

Seafloor ages beneath younger Louisville volcanoes that lie west of the Wishbone Scarp are also highly uncertain, although the crustal age (and lithospheric thickness) may increase significantly toward the Wishbone Scarp. Mortimer et al. (2006) report a U/ $\mathrm{Pb}$ zircon age of $115 \mathrm{Ma}$ from a dacite sample recovered along the western extension of the Wishbone Scarp (i.e., southwest of the bend in the Louisville Seamount Trail at $\sim 169^{\circ} \mathrm{W}$. Together with the estimated age of $\sim 86$ to $\sim 93$ Ma for Osbourn Trough spreading, it appears that crustal ages may increase from the northwestern end of the Louisville chain toward the Wishbone Scarp (Müller et al., 2008). The difference between ocean crust and seamount ages may be only 10 m.y. at Osbourn Guyot (78 Ma), the oldest seamount in the Louisville Seamount Trail, and this age difference may systematically increase to as much as 65 m.y. near the Wishbone Scarp. Variations in lithospheric thickness along the older portion of the Louisville chain (west of the Wishbone Scarp) consequently may be important for the geochemical evolution of the volcanoes, as discussed below. 


\section{Geochemical evolution of the Louisville hotspot}

The construction and geochemical history of an intraplate seamount often is envisioned to resemble that of a typical Hawaiian hotspot volcano (Clague and Dalrymple, 1988). There is, however, little empirical evidence for a similar evolutionary sequence in the Louisville Seamount Trail. Essentially, all igneous rocks dredged from the Louisville Seamount Trail are alkalic basalt, basanites, or tephrites containing normative nepheline (Fig. F6A) (Hawkins et al., 1987; Vanderkluysen et al., 2007; Beier et al., 2011). In addition, isotopic and trace element data from this seamount trail suggest a long-lived and remarkably homogeneous mantle source equivalent to the proposed "common" components FOZO (Focal Zone) or C (Fig. F6B) (Cheng et al., 1987; Hawkins et al., 1987; Vanderkluysen et al., 2007; Beier et al., 2011). The minor variations in major and trace elements appear to be controlled mostly by variable extents of melting and fractional crystallization but with little influence from mantle source heterogeneities (Vanderkluysen et al., 2007; Beier et al., 2011).

This raises important questions that will be addressed by geochemical studies of the samples cored during Expedition 330. For example, do Louisville volcanoes evolve through geochemically distinct shield, postshield, and rejuvenated stages, similar to Hawaiian volcanoes? If so, is the dominant shield stage characterized by the eruption of tholeiites or rather by alkalic lava? Tholeiites generally represent greater amounts of partial melting than does more alkalic lava. One possibility is that the typical shield stage of a Louisville volcano reflects a systematically lesser amount of partial melting than in the Hawaiian case. It is also possible that dredging may have sampled only later stage lavas that cover the shieldstage flows. Interestingly, the least alkalic lava obtained by dredging is from Osbourn Guyot near the Kermadec Trench, where extensive faulting may have exposed older shield-building lava (Hawkins et al., 1987). The basement penetration achieved during Expedition 330 may have allowed direct sampling of the waning part of the shield-building stage, providing key constraints on the geochemical and magmatic evolution of the Louisville volcanoes in this primary hotspot system.

Hawaiian shield-stage lava flows possess a wide range of isotopic and incompatible element compositions, which is even greater when data for postshield and posterosional lava are included. In contrast, incompatible element ratios (e.g., $\mathrm{Zr} / \mathrm{Y}$ and $\mathrm{Nb} / \mathrm{Y}$ ) and radiogenic isotope ratios for the Louisville Seamount Trail are surprisingly homogeneous (Fig. F6B).
Lithospheric thickness is a key control on partial melting-and thus on the composition of the produced magma-because it determines the minimum depth of the top of the melting column and limits the extent of decompressional melting that occurs in the upwelling mantle (e.g., McKenzie and Bickle, 1988). Other things being equal, greater amounts of partial melting occur under thin lithosphere, and, in a mantle containing isotopically and chemically distinct lithologies, different mantle components are likely to begin to melt at different depths (Sun and Hanson, 1976; Ellam, 1992; Phipps Morgan and Morgan, 1999; Hoernle et al., 2000; Niu et al., 2002; Ito and Mahoney, 2005; Devey et al., 2003). For the Emperor Seamounts, much of the observed isotopic and chemical variation may be related to changing proximity to a spreading center and related changes in lithospheric thickness (Keller et al., 2004; Regelous et al., 2003). In contrast, for most of the Louisville Seamount Trail, the limited geochemical variation could reflect relatively uniform melting conditions over 80 m.y. or a remarkably homogeneous plume source. Uniform melting conditions could be a result of limited variation in lithospheric thickness; however, as noted above, along-chain variations in lithospheric thickness at the time of volcanism are still being debated.

\section{Louisville as a primary hotspot}

Courtillot et al. (2003) have argued that most hotspots arise from relatively shallow levels and that no more than three primary plumes (Hawaii, Easter, and Louisville) ascend from the core/mantle boundary in the Pacific Basin. These authors suggest several criteria by which primary plumes may be assessed, the chief geochemical criterion being high ${ }^{3} \mathrm{He} /{ }^{4} \mathrm{He}$ ratios in hotspot lavas. Although agreement is not universal (e.g., Meibom et al., 2003), high ${ }^{3} \mathrm{He} /{ }^{4} \mathrm{He}$ ratios are considered by the great majority of scientists to be a sign of a deep-mantle origin (e.g., Allègre et al., 1983; O'Nions, 1987; Farley and Neroda, 1998). Hawaiian basalt, for example, has ${ }^{3} \mathrm{He} /{ }^{4} \mathrm{He}$ values as high as $35 R_{A}$ (where $R_{A}$ is the atmospheric ${ }^{3} \mathrm{He} /{ }^{4} \mathrm{He}$ ratio), and even higher values have been reported for samples from Iceland. In comparison, mid-ocean-ridge basalt (MORB) typically has values of only 7-10 $\mathrm{R}_{\mathrm{A}}$ (e.g., Graham, 2002). No He isotope data have been published for the Louisville Seamount Trail. Another geochemical indicator of a deep-mantle origin is high ${ }^{186} \mathrm{Os} /{ }^{188} \mathrm{Os}$, which is interpreted by some workers to signify Os derived from the outer core. Only a few studies of Os isotopes in oceanic hotspot lava have yet been performed, but anomalously high ${ }^{186} \mathrm{Os} /{ }^{188} \mathrm{Os}$ and ${ }^{187} \mathrm{Os} /{ }^{188} \mathrm{Os}$ ratios 
have been discovered in at least some of the primary hotspots, such as Hawaii (e.g., Brandon et al., 1999). Although interpretation of the elevated Os isotope ratios is debated (e.g., Smith, 2003), combined studies of Os and He isotopes have the highest potential to reveal any deep-mantle signature in oceanic lava. Drilling during Expedition 330 recovered a high number of basalt flows with relatively unaltered olivine crystals and oxide minerals that will allow us to assess the applicability of these geochemical criteria to the Louisville volcanic chain. If these tests indicate that Louisville does not have a deep (lower) mantle origin, this outcome will place limits on mantle flow models by forcing a shallower root for its mantle plume. Although geodynamic modeling likely cannot resolve the depth of origin between primary and secondary hotspots, geochemical results possibly can on the basis of characteristically high ${ }^{3} \mathrm{He} /{ }^{4} \mathrm{He}$ and ${ }^{186} \mathrm{Os} /{ }^{188} \mathrm{Os}$ deep-mantle plume ratios.

\section{Relation between the Louisville hotspot and the Ontong Java Plateau}

The Ontong Java Plateau has been proposed to be a large igneous province that is the product of the Louisville hotspot's initial plume-head phase (e.g., Richards and Griffiths, 1989; Mahoney and Spencer, 1991; Tarduno et al., 1991). However, existing isotopic data for Louisville dredge samples (Cheng et al., 1987; Vanderkluysen et al., 2007; Beier et al., 2011) offer no strong support for such a connection (Mahoney et al., 1993; Tejada et al., 1996). Ontong Java and Louisville samples have similar age-corrected $\mathrm{Nd}$ and $\mathrm{Sr}$ isotope values, but Louisville lava has significantly higher $\mathrm{Pb}$ isotope ratios than Ontong Java basalt (Fig. F6B), and the difference is more than can be accounted for by ingrowth of radiogenic $\mathrm{Pb}$ in the mantle source between 120 and $80 \mathrm{Ma}$ (Vanderkluysen et al., 2007). Expedition 330 drill sites will provide a much more rigorous test of any geochemical connection between the Ontong Java Plateau and the Louisville Seamount Trail to address this possible genetic relation.

\section{Mantle temperatures of the Louisville hotspot}

Comparable to other primary hotspots, potential temperatures of the Louisville mantle plume sources are expected to be $100^{\circ}-300^{\circ} \mathrm{C}$ higher than the $1350^{\circ}$ $\pm 50^{\circ} \mathrm{C}$ temperature of an upper-mantle MORB source (Putirka, 2008; Courtier et al., 2007). Fresh olivine-phyric basalt was encountered at all Expedition 330 drill sites. The alkalic (shield) lavas of the Louisville Seamounts drilled are excellent candidates for determining the $\mathrm{Mg}$-Fe compositions of the olivine phenocrysts and melt-inclusions therein. In turn, these compositions will yield information about source temperatures by relating the $\mathrm{Mg} / \mathrm{Fe}$ ratio of the olivines directly to that of the liquid from which they crystallized (e.g., Putirka et al., 2007). The challenge here is to make these determinations on the most Mg-rich olivines that also come closest to equilibration with the parental magma compositions, a task that may be more complicated for the Louisville Seamounts because all samples studied so far are relatively evolved.

\section{Melt inclusions and volatiles in volcanic glasses}

Melt inclusions can provide key insights into the "true" compositional variability of the mantle source from which the Louisville magmas were generated. Because melt inclusions are small (tens to a few hundreds of micrometers in diameter) volumes of melt trapped in phenocrysts, they can remain isolated from differentiation and alteration affecting the external bulk magma, thereby preserving more primitive liquid compositions compared to those determined from groundmass glass or bulk-rock analyses (Sobolev, 1996; Kent, 2008). If trapped in an early crystallizing phase, such as olivine, they may even reveal primary magma compositions and can provide insights into the mantle source of these magmas (Saal et al., 1998; Hauri, 2002). These inclusions often span a range of compositions wider than those exhibited by groundmass glass or bulk rock when they are being trapped at different stages in the evolution of the magma (Frezzotti, 2001; Danyushevsky et al., 2002). Melt inclusion studies will therefore complement bulk-rock analyses of Louisville basaltic rocks because potential heterogeneities are more likely to be recorded by melt inclusions. In addition, if melt inclusions are trapped before or during volatile degassing, suitable crystalline host phases (without cleavage or any other imperfections) may act as pressure vessels, which can isolate the trapped melt from pressure changes affecting the bulk magma. Melt inclusion volatiles therefore may preserve the initial magma volatile concentration and speciation and the degassing path undertaken by the magma (Wallace, 2005).

\section{Hydrothermal and seawater alteration}

Seamounts may rival mid-ocean-ridge flanks in terms of the total mass of seawater fluxed through their basement. They therefore are likely to play a critical role in regulating chemical crust-ocean exchange fluxes. In this regard, ocean-ridge-flank systems have been studied by several authors (Alt and Teagle, 1999, 2003; Bach et al., 2003), but the alteration and veining history of seamounts has not yet 
been studied in any detail. During Expedition 330, five seamounts having crustal ages between 50 and $80 \mathrm{Ma}$ and only thin sedimentary covers were drilled, providing a unique opportunity for investigating exchange fluxes between these seamounts and the ocean. Whole-rock geochemical studies as well as $\mathrm{Sr}, \mathrm{O}, \mathrm{H}$, and $\mathrm{C}$ isotopic analyses of carbonate veins and alteration minerals will provide the basis for reconstructing seawater-rock interaction through the lifetime of hydrologic activity on these seamounts. Because of the thin sedimentary cover on the Louisville Seamounts it is likely that seawater access to these volcanic basements has been long term, and thus they are excellent targets for assessing the magnitude of carbonate vein formation in aging oceanic crust and its role as a global $\mathrm{CO}_{2}$ sink.

\section{Geomicrobiology and fossil microbial traces}

Since the 1990s, microbiologists on ODP and IODP expeditions have documented the presence of microbial life in deeply buried sediments and the basaltic basement (Fisk et al., 1998; Parkes et al., 1994). Active microbial life has been detected as far below the seafloor as $1626 \mathrm{~m}$ (Roussel et al., 2008), and the introduction of molecular biology into marine ecology has led to great advances in our understanding of microbial life below the seafloor (Cowen et al., 2003; Inagaki et al., 2006; Mason et al., 2010). To date, however, microbiology studies have concentrated on sediments, with the notable exception of expeditions to the Juan de Fuca Ridge (Cowen et al., 2003) and the Atlantis Massif (Mason et al., 2010), both of which sampled oceanic crust younger than 3.5 Ma. Stable isotope evidence (Rouxel et al., 2008) and microbial fossils (Fisk et al., 1998) indicate that there is a subsurface biosphere in older basement rocks as well. Microbial fossil traces found there are believed to result from the boring activity of microorganisms that mostly colonized the volcanic glass to which the bacterial cells and filaments are connected (Thorseth et al., 1995; Fisk et al., 1998; Furnes et al., 2001). A different type of boring activity is recorded in carbonates precipitated in the veins, vesicles, and void spaces of volcanic rocks (Peckmann et al., 2008; Eickmann et al., 2009; Ivarsson et al., 2008). These carbonate cements have enclosed filaments that very closely resemble budding and branching microbial structures. Expedition 330 provides an excellent opportunity to study both living and extant microbial residents within the old, 50-80 Ma subseafloor volcanic rocks sampled at the Louisville Seamounts. Differences in microbial population between the overlying (pelagic) sediments and volcaniclastic layers and the basaltic basement are of keen interest, as is variation between lava flows with depth in the seamount structures and between seamounts of different age.

\section{Scientific objectives Primary objectives}

\section{Determine the paleolatitude change (if any) over time} for the Louisville hotspot

High-quality paleolatitude data are required to establish the Louisville hotspot's potential motion between 80 and 50 Ma relative to the Earth's spin axis and to compare this to the $15^{\circ}$ shift in paleolatitude observed for the Hawaiian-Emperor Seamount Trail during the same time period. Together with the measurement of high-resolution ${ }^{40} \mathrm{Ar} /{ }^{39} \mathrm{Ar}$ age dates for the cored lava flows, these paleolatitude data will help us distinguish between the possibilities that these primary Pacific hotspots moved coherently before $50 \mathrm{Ma}$ or, as predicted by geodynamic mantle flow models, that they show significant interhotspot motion, with the Louisville hotspot showing less or no discernible latitudinal motion and a considerable longitudinal shift toward the east. Comparison of these results with predictions from geodynamic mantle flow and plate circuit models will allow us to critically test, calibrate, and improve these models. These comparisons are of fundamental importance for understanding the nature of hotspots, the convection of the Earth's mantle, and true polar wander.

\section{Determine the volcanic history of individual seamounts and the age progression along the Louisville Seamount Trail through ${ }^{40} \mathrm{Ar} /{ }^{39} \mathrm{Ar}$ age dating}

Because volcanic activity for a single hotspot volcano can span up to $10 \mathrm{~m}$.y. when including the possibility of posterosional volcanism, establishing an accurate framework of ${ }^{40} \mathrm{Ar} /{ }^{39} \mathrm{Ar}$ ages is essential to successfully determine the paleolatitude change over time and map out the magmatic evolution within single seamounts and along the Louisville Seamount Trail. Shield-building and postshield lavas typically form over short periods of 1-2 m.y. for Hawaiiantype volcanoes and can be readily distinguished from overlying posterosional sequences (if present) because of state-of-the-art ${ }^{40} \mathrm{Ar} /{ }^{39} \mathrm{Ar}$ age determinations. The high precision of incremental heating ${ }^{40} \mathrm{Ar} /{ }^{39} \mathrm{Ar}$ age dating will allow us to establish age histories within each drill core that can be used to establish the cessation of volcanism at the end of the shield-building phase and to determine the starting time (and minimal duration) of the postshield capping and posterosional stages. 


\section{Determine the magmatic evolution of the Louisville Seamounts and their mantle source through major and trace element and isotope geochemistry}

Existing data from dredged lava suggest that the mantle source of the Louisville hotspot has been remarkably homogeneous for as long as 80 m.y. In addition, dredged lava is predominantly alkalic and likely represents a mostly alkalic shield-building stage, which contrasts sharply with the predominant tholeiitic shield-building stage of volcanoes and seamounts in the Hawaiian-Emperor Seamount Trail. Therefore, geochemical and isotopic data for basaltic lava from the five seamounts cored during Expedition 330 will provide key insights into the magmatic evolution and melting processes that produced and constructed the Louisville volcanoes while they progressed from shield to postshield (and possibly posterosional) volcanic stages. In turn, these data will help us to characterize the Louisville Seamount Trail as a product of one of only three primary hotspots in the Pacific and to test the apparently long-lived homogeneous geochemical character of its mantle source. Detailed analyses of melt inclusions, volcanic glass samples, and high-Mg olivine pheno- and xenocrysts will provide further constraints on the asserted homogeneity of the Louisville mantle plume source and the compositional evolution of this source between 80 and $50 \mathrm{Ma}$. Together, these geochemical and isotopic studies will allow us to document any fundamental differences between primary Hawaiian and Louisville hotspot volcanism.

\section{Secondary objectives}

\section{Determine whether the Ontong Java Plateau formed from the plume head of the Louisville mantle plume around $120 \mathrm{Ma}$}

One hypothesis states that the Ontong Java Plateau formed from massive volcanism around $120 \mathrm{Ma}$, when the plume head of the Louisville mantle upwelling initially reached the base of the Pacific lithosphere and started extensive partial melting (e.g., Richards and Griffiths, 1989; Mahoney and Spencer, 1991). If the Louisville Seamount Trail corresponds to the plume tail stage of the Louisville mantle plume and the Ontong Java Plateau to the plume head, the new paleolatitude estimates, ${ }^{40} \mathrm{Ar} /{ }^{39} \mathrm{Ar}$ ages, and geochemical data obtained from the recovered drill cores will help us to decide whether the oldest seamounts in the Louisville Seamount Trail were formed close to the $18^{\circ}-28^{\circ} \mathrm{S}$ paleolatitude determined from ODP Leg 192 basalt for the Ontong Java Plateau (Riisager et al., 2003) and whether they are genetically linked or not. The outcome of this hypothesis test will have significant implications for the origin of the Ontong Java Plateau and large igneous provinces in general.
2. Determine the potential temperature and degree and depth of partial melting at which Louisville seamount magmas were generated

Characterizing Louisville as one of the primary hotspots in the Pacific requires estimation of the minimum potential temperature of its mantle plume source, the degree of partial melting in this source, and the depth of the melting zone beneath the oceanic lithosphere in order to distinguish this model from alternate models, such as intraplate volcanism originating in the upper mantle from more "fertile" (i.e., more refractory) materials (e.g., Foulger and Anderson, 2005). Evidence for temperatures higher than the mean $1350^{\circ} \pm 50^{\circ} \mathrm{C}$ temperature of an upper-mantle MORB source (Courtier et al., 2007; Putirka, 2008) will be important to prove the deep thermal origin of the Louisville mantle plume. Evidence for changes in the degree and depth of partial melting, on the other hand, will be important to document the changing plume-lithosphere interactions along the Louisville Seamount Trail.

\section{Provide paleoceanographic and paleoclimate data at $40^{\circ}-50^{\circ} \mathrm{S}$ paleolatitudes in the southern ocean from cored Louisville pelagic sediments}

Thin packages of pelagic sediments cap the flattopped Louisville Seamounts. These sediments contain abundant calcareous microfossils (e.g., foraminifers and nannofossils) because they were deposited in shallow waters and above the carbonate compensation depth. Limestone sequences including a wellrecovered algae reef and macrofossils also were recovered on top of the volcanic basement or intercalated between lava flows. The fossil records can be compared with the ${ }^{40} \mathrm{Ar} /{ }^{39} \mathrm{Ar}$ radiometric age dates measured on basement samples. The timing of reef formation, and eventually the drowning of such carbonate banks, is of considerable interest because it provides evidence from the southeast Pacific for the expansion of tropical climates during past warm periods (Adams, 1967, 1983; Premoli Silva et al., 1995; Huber et al., 1995; Wilson et al., 1998; Jenkyns and Wilson, 1999). These sediments may provide a unique data set, adding to the very sparse paleoclimate record in the South Pacific at such high southern-latitude sites (Corfield and Cartlidge, 1992; Corfield and Norris, 1996; Barrera and Savin, 1999; Norris et al., 2001).

\section{Site survey data}

Three cruises surveyed and sampled the Louisville Seamount Trail before and in preparation for Expedition 330. In 1984 Lonsdale (1988) made a transit along the entire trail while collecting $3.5 \mathrm{kHz}$ and magnetic anomaly data as well as the first multi- 
beam swath bathymetry along the chain. In that cruise 25 guyots and 12 other large volcanoes were mapped, and at least one single-channel seismic reflection profile was collected across their summits. Following that initial cruise, a limited set of dredge samples (blue circles in Fig. F1B) were used for total fusion ${ }^{40} \mathrm{Ar} /{ }^{39} \mathrm{Ar}$ age dating (squares and triangles in Fig. F4A) and geochemistry (triangles in Fig. F6A).

In November 2002, Cruise 167 of the F/S Sonne (SO167; Stoffers, 2003) surveyed the Louisville Seamount Trail between the Tonga Trench and the $169^{\circ} \mathrm{W}$ bend. Subaerial lava and volcaniclastics were dredged from 11 guyots at 39 different stations (gray circles in Fig. F1B). Inductively coupled plasma-mass spectroscopy results indicate that the dredged basalt is alkalic basalt, whereas preliminary ${ }^{40} \mathrm{Ar} /{ }^{39} \mathrm{Ar}$ age data indicate a sometimes complex age history for the oldest seamounts in the trail (circles in Fig. F4A) (O'Connor et al., submitted). These samples reveal little geochemical variation along the Louisville Seamount Trail, except for a single large guyot that overlies the Wishbone fracture zone in the Pacific plate (Beier et al., 2011).

During the 2006 AMAT02RR site survey cruise the SIMRAD EM-120 echo-sounding system was used to map 72 seamounts and guyots, many with full coverage and all with at least $80 \%$ multibeam coverage. Multichannel seismic reflection data were collected along the oldest one-third of the seamount trail (Fig. F1B) using two 45-105 in ${ }^{3}$ generator-injector air guns and an $800 \mathrm{~m} \mathrm{48-channel} \mathrm{streamer,} \mathrm{resulting} \mathrm{in}$ 79 seismic lines with 69 crossing points on 22 seamounts. From these data we selected four primary and seven alternate drill sites on seven seamounts that (1) fall within the age constraints of the comparative Leg 197 experiment we proposed to carry out, (2) have a sufficient sedimentary cover of at least $10 \mathrm{~m}$, based on $3.5 \mathrm{kHz}$ subbottom profiling and side-scan reflection data, and (3) show consistent reflectors below these sediments representing basaltic basement. In addition, 29 sites were dredged on 21 seamounts and guyots (green circles in Fig. F1B). From these dredge hauls 42 groundmass and mineral separates from 17 seamounts were successfully age dated using the ${ }^{40} \mathrm{Ar} /{ }^{39} \mathrm{Ar}$ incremental heating technique (diamonds and plateau diagrams in Fig. F4) (Lindle et al., 2008; Koppers et al., 2011). Major and trace element concentrations were determined for 61 samples, and Sr-Nd-Pb isotope analyses were carried out for 49 samples (circles in Fig. F6A) (Vanderkluysen et al., 2007).

Magnetic surveys were also conducted of two seamounts and the small guyot at $168.6^{\circ} \mathrm{W}$ that was targeted for drilling (Site U1377 on Hadar Guyot). The magnetic anomaly pattern for Hadar Guyot unfortunately has very low amplitude (Fig. F7) and yields an unreasonable paleopole position, but the complexity of the anomaly pattern suggests that dual polarities might be present within this volcanic structure. In contrast, the $35.8^{\circ} \mathrm{S}$ seamount (located $1.1^{\circ}$ north of prospectus Site LOUI-3B) has a well-defined (root mean square crossover error $=3 \mathrm{nT}$ ) and simple magnetic anomaly pattern with the normal polarity, presumably reflecting formation during Chron 26n at 57.5-57.9 Ma (Cande and Kent, 1995). Seminorm inversions (Parker et al., 1987) yield paleopole positions that are relatively stable over a range of misfits (Fig. F8) and generally compatible with the Pacific apparent polar wander path (Sager and Pringle, 1987). Finally, these inversions give a paleolatitude of $\sim 49^{\circ} \pm 7^{\circ} \mathrm{S}$, similar to the present-day $50.9^{\circ} \mathrm{S}$ latitude of the Louisville hotspot. Despite the ambiguity in the interpretation of seamount magnetic anomalies (Parker, 1991) and its relatively large $1 \sigma$ uncertainty, this result may suggest that no (or little) discernible paleolatitude shift has occurred since this Louisville seamount formed around $58 \mathrm{Ma}$ and over a time interval in which the contemporary Suiko Seamount in the Emperor Seamounts showed at least a $6^{\circ}$ paleolatitude shift.

\section{Seismic interpretation}

Interpretation of the multichannel seismic data collected during the AMAT02RR site survey is complicated because the Louisville Seamounts have never been sampled by piston coring or drilling, and the seismic survey itself provided only limited velocity information. In fact, samples and data collected during Expedition 330 are essential in ground truthing the seismic interpretation and improving the final seismic images of this group of intraplate seamounts. Despite some ambiguity in interpretation, the available data provided us with the first-order information needed to successfully meet the objectives and goals of Expedition 330.

Seismic imaging and $3.5 \mathrm{kHz}$ data show that the overall thickness of the pelagic sediment cap is $<20 \mathrm{~m}$ at all primary sites, underlain by a $<55 \mathrm{~m}$ thick sequence of volcaniclastics and followed by what largely appears to be "opaque" volcanic basement with no significant reflectors. The intermediary volcaniclastic sequences show strong reflectors dipping outward from the centers of the targeted seamounts and are interpreted to represent intercalated lava flows and sediments. Many of the larger guyots (not targeted for drilling) in the Louisville Seamount Trail show a substantial thickness (up to several hundred meters) in these sequences that sim- 
ilarly dip and thicken toward their margins. Dredge samples from depths corresponding to outcrops of this unit recovered various volcaniclastic sediments, including rounded cobbles from supposedly shallow beach deposits (SO167 cruise report). On the basis of Leg 197 observations of the Emperor Seamounts, the bases of these dipping volcaniclastic sequences were taken as the contacts with lava flow-dominated basaltic basement (Kerr et al., 2006).

The thickening of the volcaniclastic sequence also has been imaged by a seismic refraction experiment carried out during the German SO195 cruise (Grevemeyer and Flüh, 2008). During this experiment a single $370 \mathrm{~km}$ long refraction line was carried out orthogonal to the overall northwest trend of the Louisville Seamount Trail and crossing the summit of the $27.6^{\circ} \mathrm{S}$ guyot, which is located $\sim 1.1^{\circ}$ south of Site U1372. On the basis of the outcome of this refraction experiment (with 35 ocean-bottom seismometer stations, spaced every $\sim 10 \mathrm{~km}$ ), Contreras-Reyes et al. (2010) were able to image the internal structure of this seamount, the oceanic crust underneath it, and the flexed shape of the MOHO (Fig. F5). Even though their data do not provide sufficient resolution for the uppermost $500 \mathrm{~m}$ of this seamount, the data give us a good idea of the velocity structure of the $27.6^{\circ} \mathrm{S}$ guyot, with (1) a sequence of "basaltic extrusives" (i.e., lava flows and $4.0-6.0 \mathrm{~km} / \mathrm{s}$ seismic velocities) extending to shallower regions and reaching $<0.5 \mathrm{~km}$ basement depth in the seamount center and (2) a sequence of "volcaniclastic infill" (i.e., 2.0$3.0 \mathrm{~km} / \mathrm{s}$ seismic velocities) starting with a very thin layer on top of the seamount and substantially thickening outward, particularly on the seamount flanks and in its flexural moat. This outcome provided confidence in our interpretation of the AMAT02RR seismic reflection profiles and our placement of drill sites away from the shelf edges of the guyots and toward the center of the smaller volcanic structures.

\section{Coring and drilling strategy}

The drilling strategy used during Expedition 330 was the same as that used during Leg 197, which provided compelling evidence for the motion of the Hawaiian mantle plume between 80 and 50 Ma (Tarduno, Duncan, Scholl, et al., 2002). Louisville seamounts equivalent in age to Detroit, Suiko, Nintoku, and Koko Seamounts in the Emperor Seamount Trail were targeted to provide the most direct comparison of the paleolatitude records of the two chains. Our principal drilling goal was to drill $350 \mathrm{~m}$ (or deeper) into the igneous basement of these seamounts in order to core and recover as many individual lava flows or cooling units as possible (see be- low). Analysis of these flows using modern paleomagnetic, ${ }^{40} \mathrm{Ar} /{ }^{39} \mathrm{Ar}$ geochronological, and geochemical techniques will allow direct comparison of paleolatitude estimates and geochemical signatures between seamounts in these two longest-lived hotspot systems in the Pacific.

\section{Paleosecular variation}

Although the time-averaged magnetic field is well approximated by a geocentric axial dipole, secular variations in the magnetic field occurring on timescales as long as $\sim 10^{5}$ y (e.g., Constable and Johnson, 2005) result in significant deviations from this simple dipolar structure. Because a paleomagnetic direction preserved in a lava flow as thermal remanent magnetization is a geologically instantaneous recording of the fluctuating geomagnetic field, robust paleolatitude estimates based on the geocentric axial dipole model require us to average out these paleosecular variations by sampling a sufficiently large number of individual lava flows. This can be achieved by sampling multiple lava flows spanning a longer geological time interval, on the order of $10^{4}$ $10^{5}$ y (Butler, 1992; Tauxe, 2010).

Planned penetration depths into the volcanic basement were therefore primarily dictated by the need for a sufficient number of lava flows to provide accurate paleolatitude data. The expected errors on paleolatitude estimates at a $\sim 50^{\circ}$ southern latitude, appropriate for the Louisville hotspot, can be illustrated via Monte Carlo simulations of field directions as drawn from two widely used paleosecular variation models-Model G of McElhinny and McFadden (1997) and TK03 of Tauxe and Kent (2004) —based on a global database of directions from lava flows of $0-5$ Ma in age, assuming that the magnitude and timescale of paleosecular variations did not change with time. These simulations suggest that $>42$ independent flow units must be recovered to achieve a nominal $2 \sigma$ uncertainty of $4^{\circ}$ in the paleolatitude estimates (Fig. F9A), and 25-30 units must be recovered if we aim more conservatively for $5^{\circ}$ uncertainty. These results also can be compared to a compilation of Deep Sea Drilling Project (DSDP)/ODP drilling statistics from other expeditions to seamount trails and large igneous provinces (Fig. F9B) that on average recovered $>20$ flow groups for $\sim 200-300 \mathrm{~m}$ of coring into volcanic basement. Measured uncertainties (Fig. F9C) in these DSDP/ODP drill cores are generally compatible with the Monte Carlo simulations, but the data scatter significantly between $3^{\circ}$ and $7^{\circ}$ uncertainties for paleolatitude estimates based on 5 or more flow units. Because the mantle flow models and global plate circuit reconstructions predict small 
paleolatitude shifts for the Louisville hotspot, a basement penetration of at least $350 \mathrm{~m}$ was required to achieve a paleolatitude uncertainty better than $5^{\circ}$.

\section{Hydrothermal and seawater alteration}

Most of the dredged samples from the Louisville Seamount Trail were highly to completely altered by hydrothermal and seawater alteration. Even though drilling during Expedition 330 provided us with much fresher basaltic material, alteration remains problematic and thus requires special analytical attention in order to maximize the amount and quality of data on rock ages and their original (erupted) compositions. Holocrystalline groundmass samples that have been carefully hand-picked and acidleached to remove alteration have been shown to provide ages concordant with ${ }^{40} \mathrm{Ar} /{ }^{39} \mathrm{Ar}$ ages of comagmatic minerals and can be interpreted as eruption ages (Koppers et al., 2000, 2004). Recent data on basalt from the AMAT02RR site survey emphasize the suitability of this technique for the Louisville Seamount Trail (Fig. F4B) (Koppers et al., 2011).

Many studies also established that altered rocks can be effectively used for determining geochemical source characteristics, particularly data for elements (lanthanides, $\mathrm{Nb}, \mathrm{Ta}, \mathrm{Zr}, \mathrm{Ti}, \mathrm{Fe}$, and $\mathrm{Al}$ ) and isotopic systems (Sm-Nd and Lu-Hf) that are largely resistant to seawater alteration. In addition, useful data can be obtained for the more sensitive $\mathrm{Sr}$ and $\mathrm{Pb}$ isotopic systems by applying mineral separation or acidleaching to remove secondary minerals (Cheng et al., 1987; Mahoney et al., 1998; Koppers et al., 2003; Regelous et al., 2003). Additionally, magmatic compositions can be inferred from the (laser) microanalysis of major and trace elements, as well as isotopic ratios, in unaltered portions of various phenocrystic phases and melt inclusions.

\section{Site selection and coring plan}

Our principal science objectives were to acquire accurate paleolatitudes, geochemistry and isotope compositions, and ${ }^{40} \mathrm{Ar} /{ }^{39} \mathrm{Ar}$ age dates for seamounts in the Louisville Seamount Trail having formation ages similar to those drilled in the Emperor Seamount Trail during Leg 197. In addition, drill sites were selected where seismic lines cross midway between the centers of the targeted guyots and their margins, a compromise designed to avoid eruptive centers (which may have fewer lava units) and marginal sites with potentially thicker volcaniclastic units and higher potential for tectonic disruption. The five seamounts targeted for drilling are relatively small edifices and typically have thinner sedimentary covers and fewer subsidiary peaks and pinnacles that may represent late-stage (posterosional) lava.
In preparation for Expedition 330, four primary sites (Fig. F1; Table T1) were selected on four flat-topped seamounts at the older end of the Louisville Seamount Trail. On the basis of new ${ }^{40} \mathrm{Ar} /{ }^{39} \mathrm{Ar}$ ages from the AMAT02RR and SO167 site surveys, the ages of these dormant volcanic structures were estimated to be 75-77 Ma (prospectus Site LOUI-1C on Canopus Guyot at $26.5^{\circ} \mathrm{S}$ ), $58.5 \mathrm{Ma}$ (prospectus Site LOUI-2B on Achernar Guyot at $33.7^{\circ} \mathrm{S}$ ), $54 \mathrm{Ma}$ (prospectus Site LOUI-3B at $36.9^{\circ} \mathrm{S}$ ), and $50.1 \mathrm{Ma}$ (prospectus Site LOUI-4B on Hadar Guyot at $168.6^{\circ} \mathrm{W}$ ). In addition, eight alternate sites (prospectus Sites LOUI-1B, LOUI6A, LOUI-6B, LOUI-7A, LOUI-7B, LOUI-8A, LOUI-8B, and LOUI-9A) were selected (Table T2). Except for the $26.5^{\circ} \mathrm{S}$ and $36.9^{\circ} \mathrm{S}$ Guyots, which both have a second set of crossing lines close to primary prospectus Sites LOUI-1C and LOUI-3B, most alternate sites are located on different but closely neighboring seamounts (also surveyed during AMATO2RR) in order to stay as near as possible to our original age-selection criterion and our overall drilling strategy. The eighth alternate site (Site LOUI-6B on Rigil Guyot at $28.6^{\circ} \mathrm{S}$ ) was added during Expedition 330.

\section{Logging and downhole measurement strategy}

Downhole logging aided in achieving the objectives of Expedition 330 by assisting in lithologic identification and recognition of structural characteristics (particularly cored volcanic basement sequences) and by providing detailed magnetic anomaly data that may allow monitoring of changes in magnetic properties and paleomagnetic directions within and between lava flows. Wireline logs provided a continuous record to aid in detecting lava flow boundaries, interlayered (baked) sediments, and alteration zones in the basement section and enabled evaluation of lava flow tilting. Determining the number of lava flow units has implications for how well geomagnetic secular variation has been sampled and hence the extent to which paleomagnetic paleolatitudes can be constrained most precisely. These logging measurements complement shipboard core measurements by recording the characteristics of lithologic units in intervals of poor core recovery and by allowing comparison of logging data to discrete sample analyses.

Combinations of four wireline logging tool strings were deployed during Expedition 330: (1) the triple combination (triple combo) tool string, (2) the Formation MicroScanner (FMS)-sonic tool string, (3) the Ultrasonic Borehole Imager (UBI), and (4) the third-party Göttingen Borehole Magnetometer $(\mathrm{GBM})$. These tools and their applications are fur- 
ther described in the sections below; additional information is available at iodp.ldeo.columbia.edu/ TOOLS_LABS/index.html.

\section{Triple combo, FMS-sonic, and UBI tool strings}

The triple combo tool string consists of several probes that record geophysical measurements of the penetrated formations and measures total and spectral natural gamma ray, density, porosity, and resistivity of the formation. These measurements enable assessment of changes in lithology and variations in alteration. The FMS-sonic tool string acquires oriented high-resolution electrical resistivity images of the borehole wall and measures compressional and shear wave forms. The high-resolution images allow small-scale fractures and lithologic variations to be detected, enable the tilt of lava flows to be evaluated, and may allow some core pieces to be reoriented. The sonic and density logs from this tool string can be used together to create synthetic seismograms, allowing correlation between the regional seismic data and lithologic units recovered from the boreholes. Two full uplog FMS runs were done for each logged hole, resulting in eight individual pad tracks, producing an electrical image that can cover $>65 \%$ of the $360^{\circ}$ borehole wall. In the case of Site U1374 the UBI was deployed as well, providing high-resolution acoustic amplitude images with 100\% coverage of the borehole wall.

FMS images, in conjunction with the UBI, can provide a comprehensive overview of structure, virtual hardness, and variation in lithofacies. Images collected with the FMS-sonic tool string are extremely helpful in picking out formation features such as vesicles, breccia, and coherent units (Bartetzko et al., 2003). To most accurately reorient the core pieces using FMS and UBI images, these tool strings are run with a General Purpose Inclinometry Tool (GPIT). However, in formations characterized by a strong remanent magnetization these orientation data can be affected. By running the GBM (see below) and comparing its data with those collected with the GPIT, more accurate image orientation can be accomplished, which in turn allows for more accurate reorientation of core pieces using FMS and UBI images (Gaillot et al., 2004).

\section{Göttingen Borehole Magnetometer (third-party tool)}

High-quality paleolatitude data are required to document the motion of the Louisville hotspot and to compare it with the $15^{\circ}$ shift observed for the Hawaiian hotspot over the same time interval. These data, in concert with detailed radiometric ages, will provide the basis for calibrating and testing various geodynamic models. The most robust paleolatitude information will be derived from detailed demagnetization studies of the cored-but azimuthally unorientedbasaltic basement samples. However, the GBM (Fig. F10) provides valuable complementary data that can significantly enhance these paleomagnetic directional studies that are critical expedition objectives.

The GBM allows fully oriented component magnetic anomalies to be determined by measuring three orthogonal components of the magnetic field (Steveling et al., 2003). The GBM includes three optical gyroscopes, which record the tool's overall rotation since the start of measurement, allowing the cumulative rotation of the tool to be compensated for in the data using a Matlab software program (S. Ehmann, Technische Universität, Braunschweig, Germany). This allows for independent determination of the intensity, inclination, and declination of the magnetization in the lava flow formations. For optimum data quality the GBM requires centralization during logging and the addition of a nonmagnetic sinker bar just above the GBM.

The GBM was developed in Göttingen, Germany, by Drs. M. Leven and E. Steveling at the Institut für Geophysik of the Georg-August-Universität (e.g., Steveling et al., 2003) to measure all three magnetic components in the walls of a borehole during downhole logging runs. This tool is currently housed at the Technische Universität in Braunschweig, Germany, and is maintained and deployed under the supervision of Professor A. Hoerdt. The GBM was successfully deployed for the first time in ODP Hole 1203A (Leg 197) in the Emperor Seamounts, although the results were used primarily to test filtering algorithms for the fluxgate sensors on the GPIT (Gaillot et al., 2004). The GBM was subsequently deployed during IODP Expedition 304/305, but shortperiod oscillations in the gyro data prevented recovery of component anomaly data. More recently, the GBM was successfully deployed in the $2.5 \mathrm{~km}$ deep Outokumpu hole in eastern Finland of the International Continental Scientific Drilling Program (Virgil et al., 2010) and now during IODP Expedition 330.

The ability of the GBM to make in situ three-component determinations of the magnetic anomalous field in the borehole and estimate both the inclination and declination of penetrated lava flows allows for the following important improvements. First, magnetization declination data from logging using the GBM may aid in recognizing temporally distinct flow units in the core, usually judged by inclination differences alone. This is an important first-order application because the number of distinct flow units is 
critical in establishing the uncertainty in paleolatitude estimates as measured from discrete core samples (by averaging out secular variation). Second, high-quality determination of the vertical and horizontal magnetic anomalies will allow in situ magnetization inclinations to be determined, which will provide complementary in situ data that may help in determining the paleolatitude history of the Louisville hotspot. And, finally, even though the fluxgate magnetometers incorporated in the GPIT are sufficient for orienting the FMS system, these sensors have relatively poor sensitivity (50 nT) and, more importantly, show substantial ( 1000 nT) offsets that limit interpretation of the data (e.g., Ito et al., 1995). The fluxgate magnetometers in the GBM have a better resolution (12 nT) and are well calibrated. For example, when the ambient field was measured with the GBM above the HSDP-2 drill hole on Hawaii (Steveling et al., 2003), the inclination of $36.5^{\circ}$ compared well with the International Geomagnetic Reference Field inclination of $36.6^{\circ}$, and the measured total field was compatible with that determined by aeromagnetic surveys.

\section{Principal results Site U1372}

Canopus Guyot is one of the oldest seamounts in the Louisville Seamount Trail, with an estimated age of 75-77 Ma (Table T1). Its volcanic edifice is located at $26.5^{\circ} \mathrm{S}, 174.7^{\circ} \mathrm{W}$ and, with a second guyot at $26.6^{\circ} \mathrm{S}$, forms two coalesced volcanic centers that span $\sim 60 \mathrm{~km}$. Site U1372 was placed on the summit plain of the northern volcanic center, close to its southern shelf edge at $1957.6 \mathrm{~m}$ water depth (Fig. F11). A $\sim 14 \mathrm{~m}$ package of soft pelagic sediment was cored using a gravity-push approach with little or no rotation of the rotary core barrel assembly, followed by standard coring into $\sim 32 \mathrm{~m}$ of basaltic breccia and coarser conglomerate materials and $\sim 187 \mathrm{~m}$ into the igneous basement. Unfortunately, the targeted depth of $350 \mathrm{~m}$ into basement could not be reached because the drill string became irretrievably stuck in rubbly volcaniclastic breccia with cobble-size fragments of basaltic lava. This required the hole to be abandoned at 232.9 meters below seafloor (mbsf) with no attempted downhole logging.

The recovered sequence of volcanic and sedimentary rocks (Fig. F12) covers the latter part of the constructional phase of the seamount at Site U1372, a brief subaerial phase, and its final subsidence below sea level, as evidenced by the overlying sedimentary rocks. From the bottom up, the sequence starts with a hyaloclastite-rich sequence, indicative of submarine explosive volcanism of alkalic basalt composition. Over time this changed to a shallow-marine and subaerial eruption environment, as evidenced by oxidized red-brown peperitic flow tops and the more massive lava flows on top of the volcanic basement. An erosional unconformity was found on top of the volcanic basement, overlain by a bluish-gray basalt conglomerate likely deposited in a nearby rocky shore environment of a volcanic island emerging in the Cretaceous. This early sedimentary cover predominantly consists of basalt breccia and contains a single horizon of foraminiferal limestone of late Campanian to early Maastrichtian age. This breccia likely formed in neritic to hemipelagic shallow-water conditions and is itself unconformably overlain by early Pliocene to Holocene foraminiferal ooze, which is evidence for sedimentation in a deep pelagic environment.

\section{Lithostratigraphy and biostratigraphy}

Two stratigraphic units predominantly composed of sedimentary deposits were recognized at the top of Hole U1372A (Fig. F12A). Stratigraphic Unit I extends to 13.50 mbsf and represents the youngest record of pelagic sedimentation on top of the seamount. Its lower boundary is defined by the first occurrence downhole of consolidated basalt breccia in Unit II. Unit I is composed of unconsolidated sandy foraminiferal ooze with local occurrences of reworked glass and pumice fragments. Analysis of grain morphology and paleontological observations indicate the influence of strong oceanic currents during deposition of the unit. The occurrence of pumice and fresh glass fragments suggests that the sandy foraminiferal ooze includes a minor tephra component, most likely derived from the nearby Tonga-Kermadec volcanic arc. Calcareous nannofossils and planktonic foraminiferal assemblages from Unit I are typically late Pleistocene-Holocene, mid-Pleistocene, and late Miocene-early Pleistocene in age.

Unit II extends from 13.50 to $45.58 \mathrm{mbsf}$ and represents an older sedimentary deposit, which we interpret to have formed under relatively shallow neritic to hemipelagic water conditions. Its lower boundary is defined by the first downhole occurrence of lava flows in the volcanic basement. Unit II is composed of basalt breccia (Fig. F13A) and conglomerate, with a minor interval of foraminiferal limestone that includes a small number of ferromanganese encrustations and inoceramid shell fragments. Petrographic description shows that the composition of the basalt clasts is similar to that of volcanic deposits in the underlying volcanic basement. Within Unit II five stratigraphic subunits were defined on the basis of clast angularity and composition of the intercobble and interboulder matrix. From top to bottom, Unit II is composed of multicolor basalt breccia (Subunit IIA); foraminiferal limestone with basalt clasts, ferroman- 
ganese encrustations, and abundant inoceramid shell fragments (Subunit IIB); multicolor basalt breccia (Subunit IIC); multicolor basalt conglomerate (Subunit IID); and a boulder-bearing bluish-gray basalt conglomerate deposited on top of volcanic basement (Subunit IIE). Bioclasts of shallow-water origin (calcareous algae and annelids; Fig. F14A) and basalt clasts occur throughout Unit II. However, clast roundness and the amount of shallow-water bioclasts increase with depth into the sequence, whereas the amount of planktonic fossils (foraminifers and calcispheres) decreases. Repeated occurrences of inoceramid shell fragments and foraminifers in the consolidated micrites and limestone of Unit II provide preliminary age estimates ranging from early Paleogene to Cretaceous (Fig. F14B). Because the breccia and conglomerates are dominantly of igneous origin and are mostly composed of aphyric and olivine-phyric basaltic cobbles and boulders, Unit II is surmised to represent a nearby rocky shore environment of a Cretaceous volcanic island. Interestingly, the entire sedimentary sequence of the late Paleogene and early Neogene is missing in Hole U1372A; Unit II therefore is unconformably overlain by Unit I.

\section{Igneous petrology}

Below the sedimentary succession of Units I and II, $187.3 \mathrm{~m}$ of volcanic rocks was penetrated from 45.6 mbsf to the bottom of Hole U1372A at 232.9 mbsf (Fig. F12B). The igneous basement section of the hole can be divided broadly into an upper $(83 \mathrm{~m}$ thick) part consisting of lava flows and a lower (104 $\mathrm{m}$ thick) part mostly composed of volcaniclastic rocks. The lava flows of Units III-X range from aphyric to highly olivine-phyric. Flows in the topmost $27.2 \mathrm{~m}$ of the succession (to $63.7 \mathrm{mbsf}$ ) have peperitic tops, implying interaction between lava and carbonate mud, whereas those in the following $28.7 \mathrm{~m}$ (to $92.4 \mathrm{mbsf}$ ) have scoriaceous tops. Together with the occurrence of oxidized flow tops, these lava flows likely erupted subaerially or in very shallow marine conditions.

The first downhole appearance of hyaloclastic material in Unit VI, which contains altered glass between two lava flows at 92.4 mbsf, marks a change to submarine conditions deeper in the seamount sequence. Volcaniclastic rocks dominate the succession from 128.9 to $228.4 \mathrm{mbsf}$ in Units XI-XVI. The volcaniclastic deposits can be divided into seven individual eruptive packages on the basis of the phenocryst content of the basaltic clasts. Three of these packages (Units XII, XIV, and XV) were separated from their underlying packages by short intervals $(0.13,0.16$, and $3.3 \mathrm{~m}$ in thickness, respectively) of vitric-lithic volcanic sandstone. In all cases the sandstone was inferred to form the basal part of the overlying package, either through similarity of phenocryst abundance (Units XIV and XV) or through a graded contact (Unit XII). Within the volcaniclastic units no unequivocal pillow lava or lava lobes were recovered, but several intervals included basalt fragments with curved surfaces, glassy selvages, and a hint of radial vesicle trains. In a few cases small pods were recovered that have delicate lobate lava contacts, indicating that they may have been emplaced in situ within the volcaniclastic deposits and were not displaced (much) afterward (Fig. F13B). Drilling terminated in Unit XVII, a thick ( $4.3 \mathrm{~m}$ penetrated), massive, and essentially unaltered olivine-augite-plagioclase-phyric basalt lava flow.

The igneous rocks in Hole U1372A typically have phenocryst assemblages of olivine, olivine + plagioclase + augite, or plagioclase + augite (Fig. F15). Olivine phenocrysts were found throughout all basement units and also in the basaltic clasts of the breccia and conglomerates of Unit II. Pyroxene phenocrysts and microphenocrysts are always titaniferous (Fig. F15D). Olivine is present in the groundmass in several of the upper series of lava flows but not in those from the lower part of the succession, implying an increase in alkalinity with time. The presence of titanaugite shows that these rocks are not tholeiitic.

\section{Alteration petrology}

The entire igneous section in Hole U1372A has undergone various degrees of secondary alteration by low-temperature water-rock interaction and weathering, ranging from slight to complete alteration. Two main intervals showing different dominant colors of alteration (Fig. F16) can be directly related to the oxidation state of the alteration processes. Down to 90 mbsf the volcanic basement has a dominantly reddish alteration color, pointing toward an oxidizing environment under likely subaerial or shallow submarine conditions. From 90 to 232.9 mbsf the alteration becomes more greenish, pointing toward more reducing conditions related to a deeper submarine environment.

Typically, basaltic lava flow units are more fresh and only moderately altered. In many cases fresh olivine phenocrysts (Fig. F15A-F15C) were encountered, as were zones with fresh volcanic glass, particularly in the hyaloclastites of Units VI and XII (Fig. F15B, F15C). Primary magmatic plagioclase and augite are generally well preserved, both as phenocrysts and in the groundmass. Plagioclase shows only minor alteration to sericite or illite in some rocks but is charac- 
teristically fresh. Augite is almost always unaltered (Fig. F15D). Usually, olivine is completely altered to iddingsite and Fe oxyhydroxide in the uppermost $90 \mathrm{~m}$ of the hole, except for a few intervals where fresh to moderately altered olivine was recovered. Olivine is absent in Units VII-XV from 90 to 200 mbsf, where mostly aphyric basalt was recovered. From $\sim 200$ to 233 mbsf the original olivine phenocrysts largely have been replaced by green clay, serpentine, Fe oxyhydroxide, and carbonates (calcite/ magnesite). Throughout Hole U1372A three main groups of alteration phases were distinguished: carbonates (Mg calcite and siderite), clay minerals (saponite, nontronite, glauconite, montmorillonite, and celadonite), and other secondary phases (e.g., zeolite, iddingsite, glauconite, Fe oxyhydroxide, and pyrite). Although these rocks have high porosity and often open void spaces, vesicles (if filled) and veins are variously filled with carbonates, clay minerals, and zeolites.

\section{Structural geology}

Structural features at Site U1372 are veins, vein networks, joints, fractures, aligned vesicles, and geopetal structures. Fractures and veins are relatively common in the upper lava flow Units III-X but are rare to absent in volcaniclastic units lower in the succession that must have deformed relatively uniformly via compaction. Veins that are present within the volcaniclastic units are concentrated along unit boundaries. Several of the lava flows (particularly in the subaerial portion above $92 \mathrm{mbsf}$ ) display moderate to strong magmatic flow alignment in an approximately horizontal direction, including the elongation and alignment of titanomagnetite. Geopetal structures in the upper part of the sequence are all horizontal, indicating that the drilled succession has not been tilted by partial flank collapse or as a result of the incipient subduction of Canopus Guyot into the Tonga-Kermadec Trench.

\section{Geochemistry}

Major and trace element analysis of igneous rocks by inductively coupled plasma-atomic emission spectroscopy (ICP-AES) indicates that alteration has not significantly obscured magmatic signatures, with the exception of $\mathrm{K}_{2} \mathrm{O}$ in some samples and $\mathrm{CaO}$ in two samples. The data indicate that most samples are alkalic basalt, although several are transitional basalt. Their compositions overlap those measured for dredge samples from other sites along the Louisville Seamount Trail but cover a smaller range of variation. Nevertheless, a sizeable range of compositions is present, with $\mathrm{Mg}$ numbers ranging from 34.9 to 73.5, $\mathrm{K}_{2} \mathrm{O}$ abundances ranging from 0.46 to 1.94 wt\% (Fig. F17A), and $\mathrm{Ni}$ abundances ranging from 46 to $472 \mathrm{ppm}$ (Fig. F17C). Zr/Ti ratios, on the other hand, lack significant downhole variation (Fig. F17B). Two samples appear to contain excess olivine phenocrysts. Much of the chemical variation in the other samples appears to be explainable as a product of (rather large) variable amounts of crystal fractionation involving olivine and lesser amounts of clinopyroxene and plagioclase. In general, the Site U1372 basalt is similar to oceanic island lava elsewhere and dredge samples from the Louisville Seamount Trail (Fig. F18). No distinction between shield and postshield stages of volcanism can be made on the basis of ICP-AES results for Site U1372.

\section{Physical properties}

Physical property data sets correlate well with the primary distinctions between the sedimentary sequence (Units I-II), units dominated by lava flows (Units III-X and XVII), and volcaniclastic intervals dominated by hyaloclastites (Units XI-XVI). The transition from oxidative alteration in the uppermost $90 \mathrm{~m}$ of Hole U1372A to dominantly green alteration indicative of more reducing submarine conditions is reflected in a gradual change from positive $\mathrm{a}^{*}$ color reflectance values to negative values downhole (Fig. F16A). Volcaniclastic Units XII and XV, in particular, show markedly lower density, $P$-wave velocity, and magnetic susceptibility and higher porosity than the surrounding units. Unit XV is also distinctive, with larger $a^{*}$ and $b^{*}$ color reflectance values and an uphole-increasing trend in natural gamma ray counts that contrasts with very low values in Unit XVI, below.

\section{Paleomagnetism}

The natural remanent magnetization (NRM) of archive halves from Cores 330-U1372A-4R through $38 \mathrm{R}$ was measured using the cryogenic magnetometer at $2 \mathrm{~cm}$ intervals (Fig. F19). The intensity measured spans a very broad range, from $3 \times 10^{-5} \mathrm{~A} / \mathrm{m}$ to $39 \mathrm{~A} / \mathrm{m}$ (median $=1.7 \mathrm{~A} / \mathrm{m}$ ), with the lowest values associated with volcaniclastic units. Most of the lava flows and a few volcaniclastic sequences also have relatively high magnetic coercivities, as reflected in high median destructive field $\left(\mathrm{MDF}^{\prime}\right)$ values, indicating that a strong peak alternating field is required to demagnetize these samples. This in turn suggests that the majority of the lithologies have retained their original remanent magnetization. Pronounced susceptibility variations mainly reflect variations in magnetic mineral content between various lava flows, volcanic breccia, and finer grained volcaniclastic sediments. The consequent use of nonmagnetic core barrels during Expedition 330 had a posi- 
tive influence on data quality because there is evidence of only minimal drilling-induced magnetic overprinting on the core samples.

The remanent magnetization directions were calculated and filtered using an automated procedure consisting of typically 6-8 demagnetization steps for each of the 3393 measured $2 \mathrm{~cm}$ intervals on the archive halves. This automatic technique selected the best-fit direction on the basis of scatter in the data, the percentage of remanence used in the calculation, and whether the resulting direction is likely to represent the primary magnetization. This fitting procedure allowed us to identify 1364 intervals with the most reliable magnetization directions. The results show a pattern of negative (normal polarity) inclinations in multiple lava flows (Fig. F20). These inclinations are usually consistent with stepwise alternating-field (AF) and thermal demagnetization results from 100 discrete samples (Fig. F21).

Documentation of the paleolatitude of Site U1372 at Canopus Guyot requires a sufficient number of flow units to provide a robust estimate of the time-averaged geomagnetic field at the site. In addition, these units must also be in situ; otherwise, the effects of later tilting or reorientation must be quantifiable from independent information. The presence of predominantly volcaniclastic material in Units XI-XVI and the limited core recovery in this interval make the recognition of in situ lava flow units challenging. In total, 81 lithologic units were defined for the basement sequence in Hole U1372A on the basis of shipboard descriptions. Approximately 20 of these units are in situ cooling units. Even though directions from the conglomerate, breccia, and hyaloclastite units are more scattered in their inclinations, reflecting the fact that some of the basalt pieces recovered from these intervals are random breccia or conglomerate clasts, several intervals may represent in situ lava flows and pods. This would further increase the number of flow units that can be used for determining the paleolatitude of Canopus Guyot around 75-77 Ma. Shore-based studies may provide additional constraints for whether these intercalated units are indeed in situ, time-independent cooling units.

\section{Microbiology}

Fifteen whole-round samples were collected for microbiological analysis from more altered rocks and rocks with higher porosities, including unconsolidated sediments (2), volcaniclastic breccia (3), and basaltic lava flows (10). These samples cover nearly all lithologic units recovered from Hole U1372A. All samples were preserved for shore-based DNA analy- sis, cell counting analysis, and $\delta^{34} \mathrm{~S}$ and $\delta^{13} \mathrm{C}$ isotope analysis. Four samples were used to inoculate culturing experiments with up to 10 different types of cultivation media, and one sample was collected for shipboard analysis to test for possible contamination via fluorescent microsphere analysis.

\section{Site U1373}

Rigil Guyot is one of the older seamounts in the Louisville Seamount Trail and has an interpolated age of 72-73 Ma, only a few million years younger than Canopus and Osbourn Guyots to the northwest (Fig. F1). This seamount is located at $28.6^{\circ} \mathrm{S}, 173.3^{\circ} \mathrm{W}$ and is part of a small cluster of two guyots and one small seamount to the south (Fig. F22). Rigil Guyot itself consists of a single volcanic center with two small topographic highs, possibly representing eruption of posterosional lavas on the western portion of its summit. During Expedition 330 two sites were drilled on the summit platform of Rigil Guyot: Site U1373 was placed close to the northern shelf edge at $1447.0 \mathrm{~m}$ water depth and Site U1374 was placed near the western rift zone at $1559.0 \mathrm{~m}$ water depth (Fig. F22). No soft sediment was present at Site U1373, and a hardground entry was made using the rotary core barrel assembly, followed by coring into a $\sim 34 \mathrm{~m}$ cover of consolidated sediments and latestage lava flows and then $31.8 \mathrm{~m}$ into igneous basement. Because reentry using a free-fall funnel failed, Hole U1373A had to be abandoned at only 65.7 mbsf. No downhole logging was carried out.

The short sequence of volcanic and sedimentary rocks recovered at Site U1373 (Fig. F23) is part of the subaerial phase in the life cycle of Rigil Guyot, characterized by late-stage volcanism and erosion in a shallow-marine or beach environment. In contrast to Site U1372 on Canopus Guyot and Site U1374 on the western flank of Rigil Guyot, the absence of volcaniclastic deposits containing submarine hyaloclastites reinforces the observation that all Site U1373 lava flow units formed during a later subaerial period following the main constructional phase of Rigil Guyot. From the bottom up, the sequence begins with a massive inflated lava flow of basaltic composition at least $22 \mathrm{~m}$ thick, followed by a series of thinner lava flows, all of which have blocky peperitic or brecciated flow tops. Only a thin cover of sediment overlies the igneous basement, with sedimentation being interrupted by the eruption of three autobrecciated basalt lava flows. The conglomerate and breccia that make up this cover are likely formed by "catastrophic" emplacement of two debris flow deposits during a late-stage volcanic period. No evidence for subsidence or any other eustatic change was found 
at Site U1373, and no significant sequence of soft pelagic sediment was encountered. Only a small sample of sand- to granule-size cuttings with remnants of modern nannofossil and foraminiferal fauna was recovered, which suggests that all pelagic sediment deposited since the Cretaceous has been removed from the seamount summit plain by strong subbottom ocean currents.

\section{Lithostratigraphy and biostratigraphy}

Stratigraphic Units I and III at the top of Hole U1373A consist of sediments, whereas the intermediary Unit II is predominantly composed of autobrecciated basalt lava flows with two minor sedimentary interbeds (Fig. F23A). Unit I extends to 9.60 mbsf and is divided into three subunits. Subunit IA is composed of a $15 \mathrm{~cm}$ thick multicolor polymict bioclast basalt conglomerate. Cement textures and bioclast composition (planktonic foraminifers, calcispheres, sponge spicules, echinoderms, annelids, algae, bryozoans, and bivalves) indicate that deposition took place in a shallow-marine environment. Subunit IB is composed of a $2.51 \mathrm{~m}$ thick matrix-supported brown basalt breccia with a few shallowmarine bioclasts (Fig. F24A). The conglomerate has a heterogeneous clast composition and a calcareousclayey matrix, interpreted as a mudflow deposit emplaced in a marine shallow-water environment. Subunit IC is a $0.39 \mathrm{~cm}$ thick multicolor bioclast basalt conglomerate similar to Subunit IA.

Unit II is predominantly a late-stage volcanic interval that is $6.10 \mathrm{~m}$ thick and includes two $<50 \mathrm{~cm}$ thick sedimentary deposits between three lava flows. The sedimentary deposits consist of fossil-free, heterolithic, multicolor basalt breccia and are interpreted as proximal debris flows.

Unit III is another sedimentary interval that was divided into four subunits. Subunit IIIA is a $1.37 \mathrm{~m}$ thick multicolor bioclast-rich basalt conglomerate similar in terms of composition and environment of deposition to Subunits IA and IC. Subunit IIIB is composed of a $6.73 \mathrm{~m}$ thick well-sorted multicolor bioclast-rich basalt conglomerate with distinctive cross-bedding and bedding structures and a heterogeneous assemblage of basalt clasts. Cement textures, fossil assemblages, and sedimentary structures indicate that Subunit IIIB was likely deposited in a beach environment. Subunit IIIC is composed of a $5.37 \mathrm{~m}$ thick multicolor bioclast basalt conglomerate and a bluish-gray basalt conglomerate. This subunit is believed to have been deposited in a shallowmarine environment. Subunit IIID includes a $4.73 \mathrm{~m}$ thick matrix-supported dark multicolor basalt breccia devoid of bioclasts, which we interpreted as a matrix-supported debris flow deposit. Similar sediments were found as interbeds in the underlying volcanic basement sequence.

Thin section investigations of microfossils were conducted on consolidated samples from Units I-III, but no age-diagnostic species could be identified (Fig. F25). Nonetheless, macrofossils of Flemingostrea sp. were found in Subunit IIIB (Fig. F25A), leading to a preliminary age for Subunit IIIB of latest Cretaceous to Miocene.

\section{Igneous petrology}

Hole U1373A penetrated a total of $37.9 \mathrm{~m}$ of igneous rocks comprising a $6.1 \mathrm{~m}$ thick sequence of volcanic breccia (including three autobrecciated volcanic flows) that makes up Unit II in the sedimentary cover and $31.8 \mathrm{~m}$ of igneous basement from the base of the sedimentary succession at $33.9 \mathrm{mbsf}$ to the bottom of the hole at 65.7 mbsf (Fig. F23B). Sedimentary Units I and III are breccia and conglomerates composed largely of pebble- to boulder-size basaltic clasts in a sandy matrix. Some basaltic clasts in Unit I have lobate margins with delicate protrusions and therefore cannot have been transported far from their source of origin. They may indicate syndepositional interaction of lava and sediment (i.e., peperite), implying a later phase of volcanism simultaneous with the formation of Unit I (Fig. F24B). Coarse-clastic sedimentation was interrupted by the emplacement of aphyric to olivine-phyric lava flows of Unit II. These flows are almost entirely brecciated, but in places the fragments appear to fit together in a jigsaw-fit texture, which is a common feature of "blocky peperites" and is widely thought to reflect in situ quench fragmentation. The top of the volcanic basement in Unit IV consists of subaerial lava flows of highly olivine-titanaugite-phyric basalt with wellpreserved olivine phenocrysts. Unit $\mathrm{V}$ consists of aphyric basalt that was also erupted in a subaerial environment, but the base of the lowest flow shows peperite mingling with sediment, as do the flows of Unit VI and the top of Unit VII. Drilling stopped within a $>22 \mathrm{~m}$ thick inflated sheet flow in Unit VII composed of fine-grained aphyric basalt (Fig. F26A).

The volcanological features of the igneous sequence drilled at Site U1373 suggest lava flowing into an area where water or water-saturated sediment is present but not fully submarine. The emplacement of lava flows in an intertidal or fluvial environment provides a plausible scenario that is consistent with sedimentologic observations. The presence of titanaugite and olivine-titanaugite phenocryst assemblages (Fig. F26B-26D) is characteristic of alkalic basalt. 


\section{Alteration petrology}

The igneous basement section recovered from Hole U1373A has undergone secondary alteration by lowtemperature water-rock interactions or weathering. The alteration of the volcanic rocks, including basalt and hyaloclastite deposits, ranges from slight to high (between 10\% and 95\%). The $>22 \mathrm{~m}$ thick massive basaltic lava flow (Unit VII) is relatively well preserved (10\% alteration). Two main intervals showing different dominant colors of alteration can be identified and directly related to the oxidation state during the alteration processes (Fig. F27). From the top of Hole U1373A to $\sim 45 \mathrm{mbsf}$ the sequence has a dominantly reddish alteration color, pointing toward an oxidizing environment under likely subaerial conditions. From $\sim 45$ to 66.2 mbsf the nearly fresh basalt is faintly greenish, pointing to more reducing conditions related to the submarine environment of lava flow emplacement.

Primary magmatic plagioclase and augite are generally well preserved, both as phenocrysts and in the groundmass. Plagioclase shows minor alteration to sericite/illite in some rocks, but is generally well preserved. Augite is almost always unaltered. Olivine is typically completely altered to iddingsite, hematite, and Fe oxyhydroxide in the uppermost $35 \mathrm{~m}$ of hole. From $\sim 35$ to 65.7 mbsf the original olivine phenocrysts are largely replaced by green clay, Fe oxyhydroxide, or carbonates (calcite/magnesite). Fresh olivine was found in a clast in Unit I, and moderately fresh olivine phenocrysts occur in Units IV and V. No fresh volcanic glass was encountered in Hole U1373A. Throughout Hole U1373A three main groups of alteration phases can be distinguished: carbonates ( $\mathrm{Mg}$ calcite and aragonite), clay minerals (saponite, nontronite, glauconite, montmorillonite, and celadonite), and other secondary phases (e.g., zeolites, iddingsite, Fe oxyhydroxide, goethite, and pyrite/chalcopyrite). Numerous vesicles and veins were observed; many are filled with carbonates and clay minerals and other secondary minerals.

\section{Structural geology}

Structural features observed at Site U1373 are generally similar to those at Sites U1372 and U1374 in terms of number and types of fractures, veins, magmatic foliations, and geopetals. Geopetal structures are horizontal, indicating that this part of the seamount has not tilted since its formation. Fractures and veins are common in the basaltic lava flows. Fractures are especially abundant in the lowermost Unit VII, a $>22 \mathrm{~m}$ thick massive lava flow with up to 11 fractures per meter, more than twice the density observed in other fractured rocks at Sites U1372, U1373, and U1374. Unit VII also has moderate to strong macro- and microscopic magmatic foliation, with directions ranging from subhorizontal to subvertical, indicating that this thick flow likely underwent several episodes of lava injection and flow inflation (Fig. F26A).

\section{Geochemistry}

Igneous samples from Site U1373 that were analyzed chemically are closely similar in both major and trace element composition to basalt from Site U1372. With the exception of one highly altered lava flow in Unit II, Site U1373 samples are only moderately altered, with weight loss on ignition (LOI) values of $<2.40 \mathrm{wt} \%$. Total alkalis $\left(\mathrm{Na}_{2} \mathrm{O}+\mathrm{K}_{2} \mathrm{O}\right)$ and $\mathrm{SiO}_{2}$ concentrations indicate that all Site U1373 samples are alkalic basalt, except one sample classified as transitional basalt. This sample is a highly olivine-augite-phyric basalt clast from Unit I with high $\mathrm{MgO}$ and $\mathrm{Ni}$ and likely hosting excess olivine phenocrysts (Fig. F28A, F28B). Its liquid composition thus may have been slightly more alkalic than the composition of the bulk rock. In addition, two other samples of high-MgO, highly olivine-augite-phyric basalt were analyzed (both from Unit IV), and they too appear to contain excess olivine. Evidence that all three high-MgO samples contain excess augite is seen in the variation of $\mathrm{Sc}$ with $\mathrm{MgO}$ and in their $\mathrm{CaO}$ contents and $\mathrm{CaO} / \mathrm{Al}_{2} \mathrm{O}_{3}$ ratios, which are higher than those of their high-MgO counterparts at Site U1372. Overall, Site U1373 data largely overlap with the data arrays of Site U1372 in diagrams of $\mathrm{MgO}$ vs. $\mathrm{Al}_{2} \mathrm{O}_{3}, \mathrm{Na}_{2} \mathrm{O}$, and $\mathrm{K}_{2} \mathrm{O}$ and in diagrams plotting incompatible elements $\mathrm{TiO}_{2}$ vs. Sr and Y (Fig. F29). Likewise, the $\mathrm{Zr} / \mathrm{Ti}$ ratio is within the same restricted range as that found at Site U1372 (Fig. F28C). Despite the general compositional similarity of Site U1373 and U1372 basalt, the two high-MgO samples from Unit IV at Site U1373 have relatively high Sr and $\mathrm{Ba}$ contents for their $\mathrm{TiO}_{2}$ values (Fig. F29). This characteristic does not appear to be caused by alteration, and thus these samples may represent a slightly different magma type than that represented by Site U1372 basalt and the majority of Site U1373 basalt.

\section{Physical properties}

The different physical property data sets from Site U1373 samples are mutually consistent and tend to correlate primarily with distinctions between conglomerate units, brecciated lava flows, peperitic basalt, and massive basalt. The brecciated lava flows of Unit II and the peperitic basalt found in Units V, VI, and VII exhibit similar, more consistent physical property values and trends, whereas conglomeratic Units I and III exhibit varying properties depending 
on the proportion of matrix and clasts. The massive basalt flows of Units IV and VII have consistently high densities, $P$-wave velocities, porosities, and natural gamma radiation (NGR) but show moderate internal variation in magnetic susceptibility and color reflectance. The variation in color reflectance agrees well with observed alteration colors across all units (Fig. F27A).

\section{Paleomagnetism}

The NRM of archive halves from Hole U1373A cores was measured using the cryogenic magnetometer at $2 \mathrm{~cm}$ intervals (Fig. F30). The intensities range from 0.08 to $20.46 \mathrm{~A} / \mathrm{m}$ (median $=2.99 \mathrm{~A} / \mathrm{m}$ ), with the highest values exclusively associated with stratigraphic Unit VII at the base of the hole. Compared to Site U1372 on Canopus Guyot, the basaltic rocks of Site U1373 have more variable $\mathrm{MDF}^{\prime}$ values, indicating that in some cases (e.g., lithologic Unit 15 in stratigraphic Unit VII) only a small peak alternating field was required to demagnetize these rock types. Other lava flows, however, are expected to have retained their original remanent magnetization, in particular in Units IV-VI (lithologic Units 6-13) that have $\mathrm{MDF}^{\prime}$ values of $34.9 \mathrm{mT}$ and higher. The more stable nature of these remanent magnetizations is evident in the demagnetization data of both archivehalf pieces and discrete samples (Figs. F31, F32). Low-coercivity components are unlikely to be related to drilling-induced magnetic overprinting, which would result in a subvertical component of magnetization, suggesting that the use of a nonmagnetic core barrel during Expedition 330 had a positive influence on data quality. Pronounced susceptibility variations seem to reflect variations in magnetic mineral content between lava flows, volcanic breccia, and also within individual peperitic lava flow tops, as shown for Unit VI and the uppermost part of Unit VII, in particular (Fig. F30C).

Best-fit remanent magnetization directions were calculated for 1436 measured $2 \mathrm{~cm}$ intervals on the archive-half cores using an automated procedure. This automatic technique selected the best-fit direction (typically 6-8 demagnetization steps) on the basis of scatter of the data, the percentage of the remanence used in the calculation, and whether the resulting direction was likely to represent the primary magnetization. This fitting procedure allowed us to identify 576 intervals with the most reliable magnetization directions (Fig. F30). These best-fit directions are consistent with stepwise AF and thermal demagnetization results from 34 discrete samples (Fig. F32). The range of inclinations recorded in Hole U1373A is broader and generally shallower than that found in Hole U1372A, with a downhole pattern of mostly negative (normal polarity) inclinations. The dis- persed inclination distribution for Hole U1373A may result from including a large number of positive inclinations (reversed polarity) recorded in the uppermost units, which comprise sediments and volcanic breccia, but also by including measurements from Unit VII, which is characterized by lower magnetic stability.

Good agreement between archive-half core and discrete sample data suggests it might be possible to obtain reliable inclinations for 10 in situ cooling units. Augmentation of this data set with results from Site U1374 on the western rift zone of Rigil Guyot is needed to increase the number of in situ cooling units to average out secular variation and achieve a more precise inclination estimate for this $\sim 72-73 \mathrm{Ma}$ seamount.

\section{Microbiology}

Five whole-round samples (5-10 cm long) were collected from Site U1373 for microbiological analysis, including samples from sedimentary conglomerate (one), basaltic breccia (one), and aphyric basaltic lava flows (three). All samples were preserved for shore-based cell counting, and four were preserved for shore-based DNA analyses and $\delta^{34} S$ and $\delta^{13} \mathrm{C}$ analyses. One sample was used to inoculate culturing experiments with six different types of cultivation media, one sample was collected for shipboard analysis of contamination via fluorescent microsphere analysis, and one sample was used to set up a stable isotope addition bioassay. Fluorescent microsphere counts were practically zero, indicating that the microspheres were not able to penetrate the core and therefore that the chance for microbial contamination is low.

\section{Site U1374}

Site U1374 was the third site drilled during Expedition 330 (Table T3) and the second of two sites drilled on Rigil Guyot (Sites U1373 and U1374). This site targeted one of the older seamounts with an interpolated age of $\sim 72-73 \mathrm{Ma}$, likely only a few million years younger than Site U1372 on Canopus Guyot to the northwest. This drill site was placed near the western rift zone of this guyot, about 10.3 $\mathrm{km}$ west of Site U1373 and west of two small, possibly posterosional topographic highs on the western portion of its summit (Fig. F22). Site U1374 was drilled at 1559.0 mbsl. About $\sim 6.6 \mathrm{~m}$ of sandy foraminiferal ooze was present, and drilling at Site U1374 was started using a gravity-push approach with little or no rotation of the rotary core barrel assembly. Following careful coring of the soft sedimentary cover, the rotary coring continued into an older $\sim 10.1 \mathrm{~m}$ thick sediment layer consisting of consoli- 
dated volcanic sandstone, a thin layer of limestone, and grayish basalt conglomerate. Following drilling through this sedimentary cover, $505.3 \mathrm{~m}$ of igneous basement was cored. Coring was particularly successful, with a record-breaking $88 \%$ average recovery in the igneous basement. Operations were completed with a downhole logging series consisting of a triple combination (triple combo) run, two runs with the Formation MicroScanner (FMS)-sonic tool string, one run with the Ultrasonic Borehole Imager (UBI), and two runs with the third-party Göttingen Borehole Magnetometer (GBM).

As at Site U1373, the upper sedimentary and volcanic sequence at Site U1374 (Fig. F33) is part of a subaerial phase in the evolution of Rigil Guyot. Both sites are characterized by late-stage volcanism, strong erosion, and sedimentation in a shallow-marine or beach environment. Because of the deep penetration at Site U1374, a deeper submarine series of sediment and volcanic rock was recovered on this western rift zone location. From the bottom up, the sequence starts with submarine volcanism, producing a predominant series of volcanic breccia units with an increasing number of in situ lava lobes and more massive flows upward in the sequence. This series is occasionally interrupted by the deposition of finegrained volcanic sandstone, particularly at the top of the volcanic breccia units, and in the bottom $186 \mathrm{~m}$ it is frequently interrupted by a series of intrusive sheets or dikes of mainly aphyric basalt. The entire lower sequence has a normal magnetic polarity, which above $\sim 45$ mbsf is overlain by a package of reversely magnetized lava flows and volcaniclastics. This difference in magnetic polarity may indicate a break in volcanic activity and a simultaneous progression to a shallow-marine environment and, in its later stages, a subaerial eruptive environment. This progression is particularly evident in the various breccia types recovered at this site, which range from green hyaloclastite breccia with frothy basaltic clasts (marine) through blocky breccia (shallower marine) to scoriaceous (near sea level or subaerial). A dramatic increase in the thickness of the sedimentary intervals above $\sim 150$ mbsf likely indicates the point at which parts of Rigil Guyot started to emerge above sea level and erosion proceeded more rapidly. Both petrography and geochemistry show that the magma that erupted at Site U1374 was alkalic throughout the entire drilled interval.

\section{Lithostratigraphy and biostratigraphy}

Sediment at Site U1374 occurs in the uppermost sedimentary cover of Rigil Guyot, in three intervals in a predominantly volcanic basement, and in various basalt breccias (volcanic or sedimentary in origin) as finer grained interclast infill deposits, thin-bedded sedimentary layers, or peperitic intervals. In total, 14 stratigraphic units and subunits were defined in the uppermost $116.45 \mathrm{~m}$ of the succession, and five sediment interbeds were identified in the lower igneous basement sequence on the basis of macro- and microscopic observations (Fig. F33).

The uppermost part of the seamount (0-6.64 mbsf) includes a very young sedimentary cover (Unit I) composed of sandy foraminiferal ooze that was deposited in a pelagic environment on the flat-topped seamount. Identification of calcareous nannofossils and planktonic foraminifers shows that this unit formed in the Pleistocene-Holocene. An older sedimentary cover showing subhorizontal bedding (Unit II; 6.64-16.70 mbsf) includes five subunits from top to bottom. Subunit IIA is a multicolor volcanic sandstone with ferromanganese-phosphate encrustations at $\sim 6.64 \mathrm{mbsf}$ (Fig. F34A). Subunit IIB (6.64-13.59 mbsf) is a layered monomict volcanic sandstone without fossils. Subunit IIC (13.59-15.05 mbsf) consists of late Maastrichtian bioturbated volcanic sandstone with abundant gastropods and shell fragments and rare (possible) ammonite fragments. Subunit IID (15.05-15.31 mbsf) is characterized by highly condensed upper Campanian bioclast foraminiferal limestone with ferromanganese-phosphate encrustations, some ammonite fragments, and burrows filled with upper Maastrichtian volcanic sandstone (probably from Subunit IIC). And, finally, Subunit IIE (15.31-16.70 mbsf) comprises upper Campanian (or older) basalt conglomerate with shallow-marine bioclasts (e.g., shell fragments, calcareous algae, and bryozoans) (Fig. F34B).

The underlying volcanic sequence, starting at 16.70 mbsf, is composed of minor basalt lava flows and abundant basalt breccia. The interclast spaces in the basalt breccia are partly filled with finer grained basalt and volcanic sandstone with a local shallow-marine bioclast component. Three thick-bedded sedimentary intervals were identified between 37.60 and 116.45 mbsf. Unit VII (37.60-41.84 mbsf) is the first such interval and is composed of polymict basalt sandstone with abundant vitric fragments and only a few shallow-marine bioclasts, layered volcanic sandstone with rare fossils, and monomict basalt breccia with larger shallow-marine bioclasts. Unit IX (63.67-84.70 mbsf) is the second sedimentary interval and is devoid of fossils. It includes two samples of polymict basalt breccia and an intermediary single interval of volcanic sandstone. The third sedimentary interval occurs at Unit XI (109.87-116.45 mbsf). The upper portion of this interval is volcanic sand- 
stone with few bioclasts, and the lower portion is grayish basalt conglomerate with abundant shallowmarine fossils.

Volcanic deposits below 116.45 mbsf include only minor occurrences of thin-bedded layers of grainsupported, poorly sorted basalt sandstone breccia interpreted as sedimentary intervals. The last occurrences of shallow-water fossils in Hole U1374A were found in two intervals of sedimentary basalt breccia at 256.75-257.49 and 290.32-291.27 mbsf, respectively. These intervals correlate with downhole changes in the nature of the volcanic deposits to decidedly submarine. Contrary to the subhorizontal bedding in the sedimentary cover, bedding orientations in the volcanic basement are locally characterized by moderately dipping $\sim 20^{\circ}-25^{\circ}$ values (Fig. F34C). Because of the small core size it is not obvious whether these dips reflect initial sedimentary dips (e.g., moderate scale cross-bedding) or tilting; the presence of horizontal geopetal structures deeper in the volcanic basement indicates that these deeper layers were not tilted.

Eight lithofacies were defined in the sedimentary cover and thicker sedimentary intervals of the volcanic basement, which permits overall characterization of the environment of deposition at Site U1374. The volcanic basement below $116.45 \mathrm{mbsf}$ is interpreted to have been deposited in a submarine environment on the slope of a former oceanic island. Within this basement the lowermost occurrence of fossil-bearing sediment at 291.27 mbsf possibly corresponds to the first-time shoaling of the island representing today's Rigil Guyot. Higher in the sequence the volcanic interval between 116.45 and $16.70 \mathrm{mbsf}$ is interpreted to have been deposited in a shallow-marine to subaerial environment on the slope of this former island. A major erosional surface likely occurs at $16.70 \mathrm{mbsf}$ at the base of Unit II, as suggested by changes in the dip of sediment bedding between the volcanic basement and sedimentary cover (see above), and is interpreted to be the result of summit erosion and the original flattening of the drilled guyot. The erosional surface is capped by a shallow-marine basalt conglomerate between 16.70 and $15.31 \mathrm{mbsf}$ and a condensed interval with ferromanganese encrustations from 15.31 to 15.05 mbsf. The age of limestone in this condensed interval of Subunit IID was assigned to the late Campanian and is interpreted to record the initial drowning of Rigil Guyot during the Maastrichtian (Fig. F35). The volcaniclastic sediment deposited on top of this limestone likely represents a record of posterosional volcanism in the latest Cretaceous, as suggested by the occurrence of ammonoid specimen fragments. A second (undated) condensed interval occurs at $\sim 6.64$ mbsf and is capped by much younger Pleistocene pe- lagic sediment. This latter unconformity represents at least 50 m.y. of missing sediment deposition.

\section{Igneous petrology}

Hole U1374A on Rigil Guyot penetrated $505.3 \mathrm{~m}$ of igneous basement comprising a succession of volcaniclastic breccia capped by lava flows and intruded, in its lower part, by a suite of intrusive sheets or dikes. The igneous sequence (Fig. F33) was divided into 148 lithologic units, which were grouped into 15 stratigraphic units (Units III-VI, VIII, X, and XIIXIX). The basement succession also includes three $4.24,21.03$, and $6.59 \mathrm{~m}$ thick sedimentary intervals (stratigraphic Units VII, IX, and XI, respectively). Magmatism recorded at Site U1374 started in a submarine environment and progressed to a shallowmarine and then subaerial environment. This progression is clearly seen in the various breccia types recovered at this site (Fig. F34D-F34G). Abundant blocky breccia probably accumulated as talus deposits through the transportation downslope of volcaniclastic debris that was shed from the fronts of submarine lava flows. In other intervals scoriaceous breccia is probably the product of hydrovolcanic eruptions resulting from the interaction of magma with water (in a shallow submarine environment) or wet sediment, whereas toward the top of Hole U1374A the number of lava flows increases and peperites are found at both the bottom and top margins of these lava flow units. Distinct eruptive packages are often separated by intervals of background sedimentation, five of which were identified at Site U1374. A dramatic increase in the thickness of these intervals in Unit XI indicates the point in time at which parts of the seamount near Site U1374 emerged above sea level and erosion proceeded more rapidly, forming more extensive deposits of basalt conglomerate, basalt breccia, and volcanic sandstone. The phenocryst assemblage in the breccia and lava flows changed from plagioclase-dominated in the lower part of the succession (Units XIV-XIX) to olivine-dominated in the upper part (Units III-XIV), suggesting that the magmas became generally more basic with time (Fig. F36). The magma erupted at Site U1374 was alkalic throughout the drilled interval. The lower $186 \mathrm{~m}$ of the succession drilled in Hole U1374A was intruded by sheets of aphyric basalt, which we interpret as dikes (Fig. F34H). Similar rocks were not encountered at higher levels, so these dike units could have extended to levels higher than the present guyot surface, where they were eroded away, or they have been truncated at a yet-unrecognized erosion surface higher in the succession.

\section{Alteration petrology}

The entire section of Hole U1374A has undergone secondary alteration by low-temperature water-rock interactions or weathering. The alteration of the volcanic rocks ranges from slight to high (5\%-95\%), 
whereas several basaltic lava flows and intrusive sheets are relatively well preserved (10\% or less). Two main but overlapping alteration intervals were identified on the basis of different dominant alteration colors, which mainly are related to oxidation state during the alteration processes. From the top of Hole U1374A to $\sim 300$ mbsf the sequence has dominantly reddish or brown alteration colors, indicative of oxidizing conditions in subaerial to transitional shallow-marine environments (Fig. F37). Deeper than $370 \mathrm{mbsf}$ the basalt ranges from slightly to highly altered and is predominantly greenish in color, indicative of more reducing conditions related to a more submarine eruptive environment (Fig. F37). Occurrences of gray and relatively unaltered basalt were encountered throughout Hole U1374A.

Plagioclase and augite are generally well preserved as phenocrysts and in the groundmass throughout the entire igneous portion of the core. Plagioclase shows minor alteration to sericite/illite in some rocks but is generally well preserved. Augite is almost always unaltered. Olivine is typically completely altered to iddingsite, hematite, carbonates, and Fe oxyhydroxide, but some sections in the core contain slightly to moderately altered olivine. Some olivine in altered rocks below $\sim 370$ mbsf is replaced by green clay, Fe oxyhydroxide, or carbonates (calcite/magnesite). Throughout Hole U1374A three main groups of alteration phases can be distinguished: carbonates $(\mathrm{Mg}$ calcite), clay minerals (saponite, nontronite, and celadonite), and zeolites and other secondary phases (iddingsite, Fe oxyhydroxides, goethite, pyrite/chalcopyrite, and thaumasite). The types of zeolite vary from phillipsite in the upper portion of the hole to analcite and gmelinite at depth, indicating a possible thermal alteration gradient. Vesicles, veins, and voids are mainly filled with carbonates and clay minerals below 300 mbsf and with zeolites below 380 mbsf.

\section{Structural geology}

Structural features at Site U1374 are dominated by veins $(N=1229)$, vein networks $(N=515$, with 3225 individual veinlets), and fractures $(N=356)$. Veins are found mostly within lava flows, although veins also occur in larger fragments within volcanic breccia units. The maximum vein width is $25 \mathrm{~mm}$, but most are considerably smaller, with average widths of $0.8 \mathrm{~mm}$. Fractures are also most common in lava units, especially the lowermost $14 \mathrm{~m}$ of the hole, with $>14$ fractures per meter recorded. Structural measurements were also undertaken for intervals with sedimentary bedding $(N=46), 35$ geopetals, 18 igneous contacts, 35 vesicle bands, and 80 instances of magmatic flow textures. The orientation of the sedimentary bedding changes significantly downhole from subhorizontal in Units I-II to dips of up to $20^{\circ}-25^{\circ}$ below $16.70 \mathrm{mbsf}$. Although inclined sedimentary layers are present, all geopetal structures are horizontal (Fig. F35B), indicating that this part of Rigil Guyot has not been tilted since deposition of the geopetal infilling material. Excellent examples of baked contacts and chilled margins were recorded from $\sim 335$ to 500 mbsf from a series of steeply dipping sheet intrusions or subvertical dikes. These dikes also contain steeply inclined vesicle bands or flow textures, which also indicate mostly near-vertical magma flow.

\section{Geochemistry}

Major and trace element data for igneous samples from Site U1374 overlap considerably with data for Sites U1372 and U1373. However, Site U1374 samples tend to have slightly lower $\mathrm{SiO}_{2}$ at similar total alkali $\left(\mathrm{Na}_{2} \mathrm{O}+\mathrm{K}_{2} \mathrm{O}\right)$ contents and thus are slightly more alkalic as a group. A diagram of total alkalis vs. $\mathrm{SiO}_{2}$ shows that most Site U1374 samples are classified as alkalic basalt, but nearly one-third of the samples are basanite or tephrite. No transitional compositions were found, in contrast to Sites U1372 and U1373. Most of the Site U1374 samples are relatively evolved (Fig. F38), with $\mathrm{MgO}$ concentrations between 2.78 and $8.54 \mathrm{wt} \%$. Major element and Sc variations indicate that olivine and clinopyroxene were the main mineralogical controls on magmatic differentiation. Incompatible element concentrations display somewhat greater overall variability relative to $\mathrm{TiO}_{2}$ than that seen for Sites U1372 and U1373, consistent with greater variability in the amount of partial melting or in source composition at Site U1374 (Fig. F39). Despite the compositional overlap and close proximity of Sites U1373 and U1374 (which are located just $10.4 \mathrm{~km}$ apart on Rigil Guyot), the rocks from the two sites cannot be correlated and probably represent distinct eruptive events. Likewise, the intrusive sheets occurring in the deeper submarine interval at Site U1374 cannot be correlated with any specific lava flow or eruption package higher up in the drilled sequence.

\section{Physical properties}

Physical property characterizations for samples recovered from Site U1374 show clear contrasts between unconsolidated sediments, massive basalt, and volcanic breccia. The intrusive sheets or dikes recovered in the lowermost $186 \mathrm{~m}$ have a characteristic physical property signature, distinct from the majority of the basalt flows, lobes, and clasts, and are marked by high NGR, magnetic susceptibility, den- 
sity, and $P$-wave velocity and low porosity. More subtle contrasts between olivine- and plagioclase-dominated units are observed in NGR and magnetic susceptibility. The downhole appearance of hyaloclastites at 327 mbsf is marked by a subtle decrease in $\mathrm{L}^{*}$ (lightness) and a more marked decrease in $P$-wave velocity and an increase in porosity. The changes in both $P$-wave velocity and porosity are more pronounced below 470 mbsf, where a shift in color reflectance (Fig. F37) toward more green and yellow spectra is also observed, correlating with the occurrence of a high proportion of fragments of "frothy" basalt glass.

\section{Paleomagnetism}

The NRM of archive-half cores from Hole U1374A was measured using the cryogenic magnetometer at $2 \mathrm{~cm}$ intervals (Figs. F40, F41). NRM intensities range from $10^{-3}$ to $\sim 20 \mathrm{~A} / \mathrm{m}$ (geometric mean $=0.82$ $\mathrm{A} / \mathrm{m}$ ), with the highest values associated with lava flows, intrusive sheets or dikes, and basalt clasts in the volcanic breccia/conglomerate units. Similar to Site U1372 on Canopus Guyot but different from the basaltic rocks of Site U1373, the paleomagnetic measurements from archive-half cores at Site U1374 show typically high $\mathrm{MDF}^{\prime}$ values, indicating that the magnetizations were largely stable and a large peak alternating field was required to demagnetize these rocks. The stable nature of these remanent magnetizations is evident in the demagnetization data of both archive-half pieces and discrete samples, which show little evidence for drilling-induced remanent magnetization, likely because a nonmagnetic core barrel was used. Several lithologic units (e.g., dikes or lava flows) and stratigraphic units are associated with changes in NRM intensity or magnetic susceptibility, and some of these changes (e.g., stratigraphic Unit XV) are also evident from the GBM logs.

Best-fit remanent magnetization directions were calculated for 13,704 measured $2 \mathrm{~cm}$ intervals on the archive-half cores using an automated procedure. This automatic technique selected the best-fit direction (typically 6-8 demagnetization steps) on the basis of the scatter of the data, the percentage of the remanence used in the calculation, and whether the resulting direction trends toward the origin of the $\mathrm{Zi}$ jderveld demagnetization diagrams. This fitting procedure allowed us to identify 5496 intervals with the most reliable magnetization directions. These best-fit directions are consistent with stepwise AF and thermal demagnetization results from 236 discrete samples (Fig. F42). Both archive-half core and discrete sample data reveal a normal polarity zone from $\sim 45$ to $522 \mathrm{mbsf}$, which is remarkably consistent for long intervals containing a wide range of lithologies in- cluding basaltic lava flows, dikes, and volcanic breccia. Both data sets also reveal a small interval of reversed polarity magnetization in the uppermost $\sim 45 \mathrm{~m}$ of the hole. Interestingly, the range of inclinations recorded in Hole U1374A is narrower and generally steeper than that found in Hole U1373A on Rigil Guyot, though possibly statistically indistinguishable pending further investigation. Both sites also show a group of positive inclinations in their uppermost units, suggesting that sediments and volcanic breccia formed during the latest-stage volcanism and deposition on Rigil Guyot recorded a reversed polarity, in contrast to the normal polarity recorded during the earlier constructional phase of this seamount edifice.

Nineteen in situ cooling units were recognized at Site U1374, providing a consistent estimate of inclination during the formation of Rigil Guyot. Importantly, similar consistency was observed in many of the volcaniclastic units, especially in the lower half of the cored igneous basement, which provided inclination values similar to intercalated lava flows or lobes. In addition, many of the intrusive sheets intruding these volcaniclastic units also have comparable negative inclinations. The good agreement between both archive-half and discrete sample data and among the lava flows, volcanic breccia, and intrusive sheets at Site U1374 suggests that a reliable inclination estimate for Site U1374 is obtainable, particularly when combining these results with the 10 in situ and (likely) contemporary lava flows recovered at Site U1373. Further augmentation of this data set with inclination data from Site U1372 on Canopus Guyot may be considered necessary to increase the number of cooling units sampled in order to better average out secular variations.

\section{Microbiology}

Twenty-nine whole-round samples (5-13 cm long) were collected for microbiological analysis at Site U1374. The lithologies of the collected samples include unconsolidated sediments (1), sedimentary conglomerate (2), volcanic breccia (24), and aphyric basaltic lava flows (2). All samples were preserved for shore-based cell counting, DNA analyses, and $\delta^{34} \mathrm{~S}$ and $\delta^{13} \mathrm{C}$ analyses. Eleven samples were used to inoculate culturing experiments with up to seven different types of cultivation media. Growth was detected in samples as deep as 400 mbsf, with media targeting sulfur-oxidizing bacteria and general heterotrophs. Five samples were used to set up stable isotope addition bioassays to determine rates of carbon and nitrogen utilization by subsurface microbes at Rigil Guyot. Two cores were seeded with fluorescent microspheres. Samples from these cores were collected 
for shipboard analysis of contamination via fluorescent microsphere counts, which revealed that microspheres are released into the drill fluid. However, all counts were reduced to zero after the three sterile seawater rinses to which all microbiology wholeround samples were subjected. This indicates that the microspheres were not able to penetrate the whole-round samples, and therefore the chance for microbial contamination is low in these samples.

\section{Downhole logging}

Four tool strings were deployed in Hole U1374A on Rigil Guyot. Three of these tool strings took measurements of natural gamma ray radioactivity, density, neutron porosity, elastic wave velocity, and acoustic and resistivity images of the borehole. The fourth specialized tool string, the third-party GBM, measured three-component magnetic field that may allow determination of the in situ inclination and declination of the eruptive units in the drilled seamount formation. Measurement depths were adjusted to obtain a common wireline log matched depth below seafloor (WMSF) scale across different logging runs. The logged depth interval for Hole U1374A was 128.1-520 m WMSF.

The downhole log measurements (resistivity, density, velocity, and neutron porosity) were used to identify nine $\log$ units in Hole U1374A: two in the section covered by the bottom-hole assembly and seven in the volcanic sequences in the open hole interval (Fig. F43). Log Unit I (0-20 m WMSF) shows a spike in gamma ray coinciding with the sedimentary cover in the drilled sequence. Log Unit II (20-128.1 m WMSF) has generally low gamma ray values while still logging inside the drill pipe. Log Unit III (128.1$240 \mathrm{~m}$ WMSF) exhibits fluctuating values for density, resistivity, porosity, and velocity and is the first unit below the end of the drill pipe. Log Unit IV (240-278 $\mathrm{m}$ WMSF) shows more consistent values for density, velocity, porosity, and resistivity. Log Unit V (278$358 \mathrm{~m}$ WMSF) is characterized at its top by a dramatic decrease in resistivity and velocity and an increase in porosity. The uppermost $\sim 12 \mathrm{~m}$ of this unit also is characterized by one of the strongest magnetic anomaly patterns recorded with the GBM in both horizontal and vertical field components. Log Unit VI (358-380 m WMSF) exhibits a marked decrease in density, resistivity, and velocity. Log Unit VII (380-469 m WMSF) has relatively consistent density values, higher stable resistivity values, lower porosity values, and higher velocity values. At the bottom of this unit the highest GBM magnetic anomaly was observed over a short interval of $\sim 5 \mathrm{~m}$, with an uncorrected vertical magnetic field anomaly of $\sim 14,000 \mathrm{nT}$. Toward the bottom of the hole, log Unit
VIII (469-490 m WMSF) is characterized by a significant decrease in resistivity, density, and velocity and an increase in porosity, and the lowest log Unit IX (490-507 m WMSF) shows a marked increase in density, velocity, and resistivity and a decrease in porosity. The magnetic field intensities observed with the GBM are the lowest for these bottom two log units.

The GBM was run twice in Hole U1374A, collecting high-quality three-component magnetic data in conjunction with the tool's rotation history using three optical gyros mounted in the top of the instrument. Negative influences from strong magnetic sources higher up in the tool string were successfully minimized by inserting a truly nonmagnetic aluminum sinker bar immediately above the GBM. At the onset of each deployment the initial orientation of the tool string relative to the Earth's rotation axis was determined by aligning the GBM with the R/V JOIDES Resolution and then determining the ship's heading using a newly installed GPS system. With the recorded rotation history of the GBM, the measured vector components can be reoriented (postexpedition) and translated into geographic coordinates, allowing for determination of in situ inclinations and declinations in the seamount formation through modeling of the remanent magnetization. The uncorrected data appear to correlate very well with changes downhole in lithology, as observed in the recovered core and in the standard downhole logging data (Fig. F44). Examples of these are stratigraphic Unit XV, which can be clearly separated from the surrounding intervals in the magnetic data, and Unit XIX, where the magnetic readings of the vertical component drop considerably at $\sim 460$ mbsf, coinciding with a change from an interval of hyaloclastites with a high abundance of scoriaceous "frothy" glass fragments to an interval of large jigsaw-fit clasts of aphyric basalt. Both uplog and downlog data are consistent with each other and between two independent runs. Further detailed investigations of the GBM data collected will focus on the separation and identification of the magnetic signals of the different in situ flow units and the determination of both inclination and declination of their NRM, with the intention of estimating the paleolatitude of the Louisville hotspot and its past virtual geomagnetic pole positions.

To conclude, lithologic and structural features were successfully imaged with both the FMS-sonic and UBI tool strings. By combining the FMS and UBI data sets a complete picture of the borehole wall in terms of fractures, clast distribution, amount of alteration, and contrasts in both resistivity and "hardness" can be obtained. The FMS and UBI images are of high quality throughout the borehole, where they accu- 
rately reproduce breccia patterns and the outlines of the more solid and massive lava flow units. The images also highlight more clast-rich breccia areas compared to more matrix-dominated zones. Moreover, they show lithologic boundaries when such contacts are not recovered in the core. Because the FMS images can be oriented with respect to north (using GPIT data collected with the same tool string) and because important structural information on key boundaries, fractures, and other features of interest can be deciphered, postexpedition research will allow individual recovered rock pieces (used for paleomagnetic analyses on discrete samples) to also be oriented back to geographic coordinates. This is a key exercise in deciphering the past motion of the Louisville hotspot between 80 and $50 \mathrm{Ma}$.

\section{Site U1375}

Site U1375 on Achernar Guyot (Fig. F45) is estimated to have an age of $\sim 59-63 \mathrm{Ma}$, and compared to Rigil and Canopus Guyots to the northwest this guyot is relatively small, only $29 \mathrm{~km}$ long and $27 \mathrm{~km}$ wide. Achernar Guyot is part of a trail of seven small guyots and seamounts that starts with Burton Guyot at the northern end. Knowledge about this extinct volcano will fill an important gap in the age versus distance relationship of the Louisville Seamount Trail and therefore will provide key information to reconstruct past plate motion and the motion of the Louisville hotspot. Site U1375 (1258.0 m water depth) was targeted in the middle of this small edifice away from the guyot's shelf edges and the thick packages of dipping volcaniclastics on its flanks, in contrast to Sites U1372, U1373, and U1374, which targeted the flanks of these guyots. After Hole U1375A was spudded in $\sim 10 \mathrm{~m}$ of soft sediment, drilling became problematic because of instabilities in the uppermost sedimentary cover, most likely caused by the presence of unconsolidated cobble deposits. After Hole U1375A had to be abandoned, Hole U1375B was spudded $\sim 350 \mathrm{~m}$ to the northwest; however, severe hole instabilities were also encountered there. To avoid further delays, Hole U1375B was abandoned and a new site was established on Burton Guyot, 91 nmi to the northwest along the Louisville Seamount Trail. In total, three cores were recovered from Holes U1375A and U1375B before the holes were abandoned. The recovered material included $\sim 1.5 \mathrm{~m}$ of carbonate-cemented volcanic breccia from Hole $\mathrm{U} 1375 \mathrm{~A}$ and a $57 \mathrm{~cm}$ thick interval of microgabbro (dolerite) from Hole U1375B. No downhole logging could be carried out, and no microbiology samples were taken.

Foraminiferal ooze and volcanic breccia cored in Hole U1375A represent the pelagic cap and an older sedimentary cover at Achernar Guyot, similar to the sedimentary covers at all other sites in the Louisville Seamount Trail. The moderately olivine-augite-phyric microgabbro (dolerite) recovered from Hole $\mathrm{U} 1375 \mathrm{~B}$ is likely from a large boulder that is part of the sedimentary cover as well, even though no upper and lower contacts were recovered.

\section{Lithostratigraphy and biostratigraphy}

Sediment at Site U1375 was mostly restricted to Hole U1375A and represents a pelagic cap and an older sedimentary cover of Achernar Guyot. Two stratigraphic units were defined on the basis of compositional and textural characteristics of the sediment at macro- and microscopic scales. The uppermost part of Hole U1375A (Unit I) was retrieved with only poor $(\sim 2 \%)$ recovery and a few cuttings retrieved in the core catcher (CC) of Core 330-U1375A-1R. Calcareous nannofossils and planktonic foraminifers observed in the sandy foraminiferal ooze of Unit I display an age range of latest Miocene-Holocene. This young sediment resembles foraminiferal ooze recovered in the uppermost parts of Sites U1372 on Canopus Guyot and U1374 on Rigil Guyot and is interpreted to represent a pelagic cap on top of the drowned seamount. An older sedimentary cover (Unit II) in Hole U1375A occurs between 8.50 and 10.11 mbsf (Fig. F46). From top to bottom this stratigraphic unit includes a ferromanganese-phosphate encrustation at $~ 8.50$ mbsf; a lower to middle Paleocene grain-supported, poorly sorted multicolor basalt conglomerate between $\sim 8.50$ and 9.34 mbsf; and an altered monolithic, matrix-supported, poorly sorted multicolor basalt breccia between 9.34 and 10.11 mbsf. The composition and texture of the sediment suggest that Unit II in Hole U1375A includes a hemipelagic interval (Subunit IIA) that was probably deposited after the drowning of Achernar Guyot on top of an older debris flow deposit (Subunit IIB; Fig. F46B). Calcareous nannofossils and planktonic foraminifers observed in Section 330-U1375A-2R-1 (Fig. F47) give a preliminary age of Paleocene for the Subunit IIA breccia, indicating a >55 m.y. interval represented by the unconformity between Units I and II.

\section{Igneous petrology}

Hole U1375A was drilled to $11.5 \mathrm{mbsf}$ and recovered $1.5 \mathrm{~m}$ of sedimentary rocks containing five types of volcanic clasts. The clast types found in Subunits IIA and IIB include aphyric basalt, moderately olivineaugite-phyric basalt, moderately augite-olivine-plagioclase-phyric basalt, and highly olivine-augite-phyric basalt. Hole U1375B was drilled to 8.5 mbsf and recovered $57 \mathrm{~cm}$ of igneous rock. Unit I, the only unit to be defined for Hole U1375B, is composed of 
moderately olivine-augite-phyric microgabbro (dolerite) with olivine and augite phenocrysts that are $>10 \mathrm{~mm}$ (Fig. F48).

\section{Alteration petrology}

The entire succession recovered from Holes U1375A and $\mathrm{U} 1375 \mathrm{~B}$ has undergone secondary alteration by low-temperature water-rock interactions or weathering. The overall alteration of the volcanic clasts in sedimentary units from Hole U1375A ranges from slight to high $(10 \%-60 \%)$, whereas the moderately olivine-augite-phyric microgabbro (dolerite) from Hole U1375B varies from moderate to high (55\%). Plagioclase and augite are generally well preserved as phenocrysts and in the groundmass throughout the entire igneous portion of the core. Olivine is typically completely altered to iddingsite, hematite, Fe oxyhydroxides, and carbonates. Alteration phases are mostly carbonates (Mg calcite), brown clay minerals, and other secondary phases (iddingsite, Fe oxyhydroxides, and goethite). Additionally, the microgabbro from Hole U1375B is characterized by millimeter-thick veins of goethite.

\section{Structural geology}

Structural features in Hole U1375A are veins and vein networks in sedimentary clasts and geopetal structures in the surrounding sediments. The geopetals are horizontal, indicating that this part of Achernar Guyot has not been tilted since deposition of the geopetal infilling material. Veins and vein networks are common within the clasts and are as wide as $8 \mathrm{~mm}$, although they are typically much thinner. In Hole U1375B several veins are present in the microgabbro (dolerite). Most of these veins are steeply dipping, with thinner conjugate veins at shallow dips.

\section{Geochemistry}

One sample of the Unit I microgabbro from Hole U1375B was analyzed chemically. It is moderately altered and highly evolved and represents one of the most alkalic rocks recovered during Expedition 330. Data for the sample lie in the field of basanite and tephrite in a diagram of total alkalis $\left(\mathrm{Na}_{2} \mathrm{O}+\mathrm{K}_{2} \mathrm{O}\right)$ vs. $\mathrm{SiO}_{2}$. The microgabbro appears to be the product of crystal fractionation dominated by olivine and, to a lesser extent, augite. It has slightly lower $\mathrm{Zr}$ and $\mathrm{Y}$ for its $\mathrm{TiO}_{2}$ content than do igneous rocks from Sites U1372-U1374 and U1376, suggesting that it may represent a different magma type.

\section{Physical properties}

Physical property characterization was conducted for material recovered from Holes U1375A and U1375B.
The data sets are mutually consistent and fall within the ranges expected, based on the identified lithologies. In Hole U1375A, magnetic susceptibility, bulk density, and NGR all moderately decrease downhole, likely because of a reduction in basaltic clasts, though they may also be affected by the fragmented nature of the recovered material. The $57 \mathrm{~cm}$ of microgabbro recovered in Hole U1375B generally has higher magnetic susceptibility and bulk density values and similar NGR values compared to those observed in Hole U1375A. Material from both holes shows overall color reflectance characteristics that are more yellow than blue. In terms of redness versus greenness, the sedimentary rocks of Hole U1375A are consistently more red than green, whereas the single igneous unit from Hole U1375B has a more neutral color.

\section{Paleomagnetism}

Although there are no hints that the single $\sim 57 \mathrm{~cm}$ long microgabbro unit from Hole U1375B may be an in situ unit, it was nevertheless measured for remanent magnetization. The obtained average inclination for this single rock is $36.3^{\circ} \pm 1.6^{\circ}$ (determined from archive-half core data using Fisher statistics). A single discrete sample taken from the same unit was interpreted as having a broadly consistent (reversed polarity) direction.

\section{Site U1376}

Site U1376 on Burton Guyot was the fifth site drilled during Expedition 330 (Table T3). This site and seamount have an estimated age of $\sim 64 \mathrm{Ma}$, slightly older than Site U1375 on Achernar Guyot. Similar to Site U1375, new age data from Burton Guyot will fill an important gap in the age versus distance relationship of the Louisville Seamount Trail, providing key information to reconstruct past plate motion and the motion of the Louisville hotspot. This seamount is one of the smallest volcanoes in the Louisville Seamount Trail, having a base diameter of $<30 \mathrm{~km}$. Site U1376 was targeted in the middle of this small edifice (Fig. F49), away from its shelf edges and any packages of dipping volcaniclastics on its flanks; the latter sequences were specifically targeted at Sites U1372, U1373, and U1374. The summit of Burton Guyot is characterized by two small topographic highs on its eastern end. Site U1376 was placed between these highs at $\sim 1503 \mathrm{~m}$ water depth. Burton Guyot shows no evidence of tilting.

Hole U1376A was spudded into a sequence of consolidated sediment representing an almost complete section of the sedimentary cover of Burton Guyot, which is $\sim 42 \mathrm{~m}$ thick and formed toward the end of the Cretaceous. This ancient cover formed very late 
in the life cycle of this volcanic island and includes evidence of posterosional or rejuvenated volcanic activity. The sedimentary cover begins from the top with a sequence of volcanic sandstone and breccia with multiple ferromanganese and chalk encrustations that overlies a remarkable $\sim 15 \mathrm{~m}$ thick white algal boundstone. This sediment must have formed after the volcanic island was planed off and started to slowly subside. At its base, the sedimentary cover is composed of basalt conglomerate unconformably overlying igneous basement, into which drilling continued for $140.9 \mathrm{~m}$. The igneous basement is composed of a series of submarine volcanic products of predominantly alkalic basalt composition. Average recovery in igneous basement was remarkably high $(76 \%)$. Operations were completed after a series of downhole logging runs, including a triple combo run, one run with the third-party GBM tool, and two runs with the FMS-sonic tool string.

Record of a posterosional or rejuvenation phase of magmatism at Site U1376 is provided by the volcanic sand and breccia of sedimentary Unit I (Fig. F50). Clasts in these sediments imply at least two magma types. First, some of the sand layers contain fragments of hornblende and biotite, implying the eruption of magma more evolved than that represented by the more basic basement succession. Second, Subunit IC contains olivine-pyroxene aggregates that may be mantle xenoliths. This is supported by the occurrence in Subunit IC of partly resorbed orthopyroxene xenocrysts in basalt clasts with clear reaction coronas, suggesting that the rejuvenated stage magmas were strongly alkaline.

Drilling Hole U1376A into the center of Burton Guyot provided direct access to a deeper portion of the seamount, explaining why no subaerial eruptive products were encountered and why, instead, a sequence of submarine pillow basalts, hyaloclastites, and autobrecciated lava flows was cored (Fig. F50). The presence of olivine and augite phenocrysts in this basalt and the complete absence of plagioclase phenocrysts suggest that the seamount magma was alkaline and more basic than that at Sites U1372, U1373, and U1374, as indicated by most of the drilled volcanic rocks. Geochemical analyses show that the basalt at Site U1376 is slightly less alkaline, although it is still classified as transitional basalt rather than tholeiitic because it contains titanaugite or olivine in the groundmass throughout the entire drilled interval.

\section{Lithostratigraphy and biostratigraphy}

Sediments overlying the igneous basement at Site U1376 were divided into two stratigraphic units defined on the basis of compositional and textural characteristics at macro- and microscopic scales (Figs. F50A, F51A-F51D). Unit I represents a younger sedimentary cover that extends from the seafloor to 23.45 mbsf. This cover is mostly composed of monolithic juvenile volcaniclastic deposits that extend from 4.50 to 21.48 mbsf (Fig. F52A). These deposits are interpreted as a possible record of a rejuvenated volcanic stage of Burton Guyot in a hemipelagic or pelagic environment. Other deposits of Unit I include layered volcanic breccia and sandstone, which are interpreted as turbidites and possible hyperconcentrated flow deposits. Four thin $(<3 \mathrm{~cm}$ thick) ferromanganese crusts occur in the uppermost part of the drilled sequence, which also yielded a minor amount of nannofossil- and foraminifer-bearing chalk (Fig. F51A). Nannofossils found in the upper part of Subunit IA indicate a preliminary age of middle to late Miocene.

Unit II represents an older sedimentary cover of Burton Guyot that extends between 23.45 and 41.93 mbsf. Subunit IIA comprises a $15.15 \mathrm{~m}$ thick interval of limestone (classified as boundstone-rudstone; Fig. F51C) composed of abundant red algae and minor amounts of other shallow-marine fossils. This interval is interpreted to represent an algal reef that developed in very shallow marine conditions during subsidence of the drilled seamount. Subunit IIB between 38.60 and 41.93 mbsf is composed of basalt conglomerate with few shallow-marine bioclasts (Figs. F51D, F52B). The conglomerate was emplaced on top of an erosional surface that marks the boundary between the sedimentary cover and underlying volcanic basement of Burton Guyot. No age-diagnostic microfossils were identified in Subunit IB through Unit IV, but molluscan fossils may indicate a later Cretaceous age for Subunit IIB.

\section{Igneous petrology}

The $140.9 \mathrm{~m}$ basement section cored at Site U1376 on Burton Guyot comprises a succession of basaltic breccia, pillow lava, and massive lava flows. Two stratigraphic units were defined on the basis of different phenocryst content. Unit IV contains mostly olivine phenocrysts and is overlain by Unit III, which contains olivine and augite phenocrysts (Figs. F50B, F51E-F51G). From the bottom up the succession starts with $13.1 \mathrm{~m}$ of mostly olivine-phyric basalt breccia, but an interval of highly vesicular aphyric basalt (166.5-167.2 mbsf) on top of this breccia heralds the arrival of a second magma type producing aphyric basalt. The next $31.7 \mathrm{~m}$ comprises heterolithic breccia with olivine-phyric and aphyric basalt clasts and thin flows of aphyric basalt. This interval records a period when two types of magma were erupted in the area at the same time. The upper 
part of this interval (lithologic Unit 26) contains a number of highly vesicular fragments of aphyric and olivine-phyric basalt, which also are oxidized and may provide evidence for a period of shallow-water or subaerial volcanism. Two thin flows of aphyric basalt separated by a $24 \mathrm{~cm}$ thick interval of olivinephyric basalt breccia (lithologic Units 22-24) mark the highest occurrence of aphyric basalt in the recovered eruptive succession (127.57 mbsf).

The uppermost $17.35 \mathrm{~m}$ interval of Unit IV is composed of olivine-phyric hyaloclastite breccia containing a high proportion of fresh glass (Figs. F51F, F53C). Unit IV ends at an erosion surface that marks the beginning of Unit III and a change from magma crystallizing olivine alone to a slightly more evolved one that crystallized olivine and augite. Unit III includes a $33.11 \mathrm{~m}$ thick massive lava flow (lithologic Unit 15; Fig. F53A, F53B). The presence of pillow lava high in the Unit III succession suggests that most, if not all, of the basement section was erupted in a submarine environment.

Intrusive sheets (dikes) cutting Unit IV represent the last magmatic event recorded in the basement section of Burton Guyot (Fig. F51G). They were not seen in Unit III but may have extended through it. Because there are no aphyric basalt units in Unit III, these dikes cannot be linked directly to any of the recovered volcanic units above its highest occurrence in the top of Unit IV. It is possible, however, that the dikes penetrated Unit III and fed lava flows that have since been removed by erosion. Alternatively, they may have fed aphyric lava flows similar to those in Unit IV and have been truncated at a possible erosion surface between Units III and IV. The presence of what looks like a fragment of a dike at the postulated erosion surface between Units IV and III supports the latter hypothesis.

Unit I, on top of the drilled sequence, comprises four subunits of volcanic sand and breccia representing the products of a phase of volcanism that postdates the erosion and submergence of Burton Guyot. Clasts from Unit I, therefore, are the only certain materials from a posterosional or rejuvenation phase of magmatism that were recovered during Expedition 330. The clasts are mostly composed of fragments of basalt, but some layers are dominated by angular fragments of glass (Fig. F52A) with subordinate grains of plagioclase, augite, altered olivine, hornblende, and rare biotite. Basaltic clasts from Subunit IC contain anhedral crystals of orthopyroxene surrounded by coronas composed of tiny clinopyroxene crystals (Fig. F53D). These are most likely xenocrysts derived from disrupted mantle xenoliths.

\section{Alteration petrology}

Overall, the cored succession from Hole U1376A has undergone some degree of secondary alteration by low-temperature water-rock interactions or weathering, but large intervals are only slightly altered. The alteration of the volcanic rocks, consisting of basaltic flows, basaltic breccia, and hyaloclastite deposits, ranges from slight to high (2\%-95\%). Several basaltic lava flows are relatively well preserved (10\% or less).

Core descriptions and thin section observations show that rocks in Hole U1376A are defined by a single overall alteration type typical for submarine environments. From the top of Hole U1376A to the bottom, the sequence displays a greenish color indicative of reducing conditions related to the submarine emplacement environment (Fig. F54). Only minor and sporadic intervals in the uppermost $60 \mathrm{~m}$ of core show some reddish/brown alteration. Augite is well preserved as phenocrysts and in the groundmass throughout the entire igneous portion of the core. Some olivine is completely altered to iddingsite, hematite, and Fe oxyhydroxide near the top of the core, but large portions of core contain fresh to slightly altered olivine. Some olivine in the greenish altered rocks is replaced by green clay and carbonates (calcite/magnesite). Overall, three main groups of alteration phases could be distinguished, largely dominated by carbonates ( $\mathrm{Mg}$ calcite, aragonite, and siderite) and clay minerals (saponite and nontronite). Other secondary phases (iddingsite, Fe oxyhydroxides, hematite, and goethite) are present, and zeolites constitute only a minor amount of the alteration assemblage. Additionally, numerous vesicles and veins were observed that are mainly filled with carbonates and clay minerals.

\section{Structural geology}

Structural features at Site U1376 are dominated by veins ( $N=1190$, with 1489 individual features) and vein networks ( $N=280$, with 1995 individual veinlets). This site has the highest vein density of any Louisville site, with a maximum density of 39 veins per meter. Veins are also commonly wider than previously observed, with numerous veins between 5 and $10 \mathrm{~mm}$ wide, up to a maximum of $30 \mathrm{~mm}$, indicating higher fluid flow than at previous sites. In further contrast to other Louisville sites, veins and vein networks are abundant in breccia and hyaloclastites in addition to rheologically hard lava units, with the highest vein density actually occurring in hyaloclastite units at $\sim 62$ and 170 mbsf. The veins are dominantly shallowly dipping and often have subvertical fibrous mineral infills, both of which may indicate 
subvertical tension within this part of the seamount. The few fractures that are unfilled $(N=55)$, are present mostly in the rheologically hard lava flows and intrusive sheets. Geopetal structures $(N=26)$ are overall horizontal, indicating that this part of the seamount has not been tilted since deposition of the geopetal infilling material. Structural measurements were also undertaken for intervals with sedimentary bedding $(N=153)$ and seven igneous contacts.

\section{Geochemistry}

Major and trace element compositions of 13 igneous samples from Site U1376 on Burton Guyot show general similarities to those from Site U1372 on Canopus Guyot and, to a lesser extent, Sites U1373 and U1374 on Rigil Guyot (Figs. F55, F56). However, as a group, the Site U1376 rocks are less alkalic. Alteration is generally moderate, and on a diagram of total alkalis $\left(\mathrm{Na}_{2} \mathrm{O}+\mathrm{K}_{2} \mathrm{O}\right)$ vs. $\mathrm{SiO}_{2}$ most of the Site U1376 samples are classified as alkalic basalt, whereas four are transitional basalt. Olivine appears to have been the principal control on magmatic evolution. Seven highly olivine-phyric samples have high $\mathrm{MgO}$ (between 11.85 and 16.79 wt\%) and high Ni contents, likely because they contain excess olivine crystals. However, this high-MgO basalt is distinct from other high-MgO rocks recovered during Expedition 330 in having somewhat lower $\mathrm{Al}_{2} \mathrm{O}_{3}$ concentrations. In addition, downhole chemical variations indicate that three different magma types are represented among the lava samples from Site U1376, which is generally consistent with the petrographically defined stratigraphic units (Fig. F55). One of the two aphyric dikes encountered in Unit IV is chemically similar to samples of low-MgO olivine-phyric lava from Unit IV, but the other dike has a significantly higher $\mathrm{Ba} / \mathrm{Y}$ ratio than other Site U1376 basalt.

\section{Physical properties}

Physical property characterizations show clear contrasts between lithified volcanic sandstone and conglomerate, carbonates, lava flows, and pervasive volcanic hyaloclastites and breccia. In particular, the boundstone of Subunit IIA is characterized by very low magnetic susceptibility and NGR. These carbonate samples have higher $P$-wave velocities and lower porosities than predicted on the basis of their densities, reflecting their different chemical compositions when compared to basaltic lithologies. The $33 \mathrm{~m}$ thick massive lava flow in Unit III is characterized by a downhole increase in magnetic susceptibility, $P$-wave velocity, and density within the unit.

\section{Paleomagnetism}

The NRM intensity of archive-half core samples from Hole U1376A ranges from $10^{-4}$ to $\sim 10 \mathrm{~A} / \mathrm{m}$ (geomet- ric mean $=0.4 \mathrm{~A} / \mathrm{m})$. The lowest values are associated with the white algal boundstone in Subunit IIA and the hyaloclastite in Unit IV, and the highest values are from the lava flows, intrusive sheets, and basalt clasts in the volcanic breccia of Units III and IV (Fig. F57). The most abrupt variations in NRM intensity and magnetic susceptibility occur at the boundary of Unit I and Subunit IIA, where heterolithic volcanic breccia and volcanic sandstone at the base of Unit I are characterized by NRM intensities and susceptibilities that are roughly three orders of magnitude higher than for the algal boundstone of Subunit IIA. Both NRM intensity and magnetic susceptibility increase systematically with depth through the algal boundstone and into the heterolithic conglomerate of Subunit IIB. Significant NRM and susceptibility variations also occur in the volcanic basement (Units III and IV), with lava flows and dikes typically having NRM intensities in the range of $1-10 \mathrm{~A} / \mathrm{m}$. This same range of variations is also apparent in the $33 \mathrm{~m}$ thick massive lava flow at the bottom of Unit III (lithologic Unit 15; 72.21-105.32 mbsf). However, magnetization values for the volcanic breccia are quite variable, with the hyaloclastite breccia of lithologic Unit 21 ( 114-127 mbsf) having NRM values ranging from $>1$ to low values of $\sim 10^{-3} \mathrm{~A} / \mathrm{m}$, similar to that of the weakly magnetized limestone recovered at this site.

Best-fit remanent magnetization directions were calculated for 3947 measured $2 \mathrm{~cm}$ intervals on the archive-half cores using an automated procedure (Fig. F58). This automatic technique selected the best-fit direction (typically 6-8 demagnetization steps) on the basis of the scatter of the data, the percentage of the remanence used in the calculation, and whether the resulting direction trends toward the origin of the Zijderveld demagnetization diagrams. This fitting procedure allowed us to identify 1580 intervals with reliable magnetization directions. These best-fit directions are consistent with stepwise AF and thermal demagnetization results from 99 discrete samples (Fig. F59). Both data sets reveal very consistent reversed polarity magnetization throughout the hole, with $<1 \%$ having negative inclinations.

Eleven in situ cooling units were recognized at Site U1376. Importantly, as at Sites U1373 and U1374 on Rigil Guyot, very similar inclinations were measured for volcaniclastic and sedimentary units at Site U1376 on Burton Guyot, as well as for two intrusive dikes intruding Unit IV. Therefore, the good agreement between archive-half and discrete sample data and among lava flows, volcaniclastic materials, and dikes suggests it is possible to obtain a reliable paleolatitude for Site U1376. Detailed postexpedition measurements are required to better understand the processes causing a consistent magnetization across 
different lithologies and across the entire recovered seamount sequence.

\section{Downhole logging}

Three tool strings were deployed in Hole U1376A at Burton Guyot. Two tool strings took measurements of natural gamma ray radioactivity, density, neutron porosity, and elastic wave velocity and collected borehole resistivity images. The third tool string, containing the third-party GBM, measured the three-component magnetic field of the drilled seamount formation. Measurement depths were adjusted to match across different logging runs, obtaining a WMSF depth scale. The logged depth interval for Hole U1376A was 80.4-182.3 m WMSF. Resistivity, density, compressional wave velocity, and neutron porosity derived from downhole logging measurements were used to identify $13 \log$ units in Hole U1376A: 3 in the section covered by the bottomhole assembly and 10 in the volcanic sequences in the open hole interval (Fig. F60). These log units correlate with changes from massive basalt flows (stratigraphic Unit III) to units dominated by volcanic breccia and interlayered aphyric and olivine-phyric flow units (stratigraphic Unit IV).

The GBM was run once in Hole U1376A, collecting high-quality three-component magnetic data in conjunction with tool rotation history using three optical gyros mounted in the top of this instrument (Fig. F61). However, GBM data also show that the massive lava flow at the bottom of stratigraphic Unit III is not as homogeneous as it appears in the paleomagnetic data obtained from the recovered cores in Hole U1376A. Additionally, in the unrecovered section of hole between $~ 130$ and 140 mbsf the GBM shows strong variations. During postexpedition work the measured horizontal magnetic component will be split into north and east components, which should provide further insight into these observed variations. Further detailed investigations of the GBM data collected will focus on separation and identification of the magnetic signals of the different in situ flow units and determination of both the inclination and declination of their NRM, with the intention of accurately determining the paleolatitude of the Louisville hotspot and its past virtual geomagnetic pole positions.

Finally, many lithologic and structural features were imaged with the FMS-sonic tool string, in particular highlighting fractures, clast size, and the shape and distribution of massive basalt versus brecciated material. Of particular importance is FMS coverage of the unrecovered section between $\sim 130$ and 140 mbsf because this coverage will provide valuable information for reconstructing the lithology for this interval.
Because FMS images can be oriented with respect to north and because important structural information on key boundaries, fractures, and other features of interest can be deciphered, postexpedition research will allow individual recovered rock pieces (used for paleomagnetic analyses) to be oriented back to geographic coordinates. This is a key exercise in deciphering the past motion of the Louisville hotspot between 80 and $50 \mathrm{Ma}$.

\section{Microbiology}

Eleven whole-round samples $(5-13 \mathrm{~cm}$ long) were collected for microbiological analysis. The sample lithologies collected were volcanic sandstone (2), boundstone (2), volcanic breccia (3), and basaltic lava flows (4). All samples were preserved for shorebased cell counting, DNA analyses, and $\delta^{34} S$ and $\delta^{13} \mathrm{C}$ analyses. Five samples were used to inoculate culturing experiments with up to 10 different types of cultivation media. Media targeting sulfur-oxidizing bacteria and general heterotrophic bacteria were the most successful, and growth was detected in samples from as deep as 174 mbsf. Two samples were used to set up stable isotope addition bioassays to determine rates of carbon and nitrogen utilization by subsurface microbes at Burton Guyot. One core was seeded with fluorescent microspheres, from which samples were collected for shipboard analysis of contamination via fluorescent microsphere counts. No microspheres were detected on the outside or inside of the whole-round sample, indicating a low likelihood of microbial contamination.

\section{Site U1377}

Site U1377 at Hadar Guyot was the sixth and last site drilled during Expedition 330, and with a measured ${ }^{40} \mathrm{Ar} /{ }^{39} \mathrm{Ar}$ age of $50.1 \mathrm{Ma}$ (Koppers et al., 2011) it is the youngest Louisville seamount drilled and is similar in age to Koko Seamount in the Hawaiian-Emperor Seamount Trail (Fig. F1). Hadar Guyot shows no evidence of tilting and was formed just to the west of the Wishbone Scarp that marks the oceanic crust in that region of the Pacific plate. Hadar Guyot is the smallest seamount cored during Expedition 330 , consisting of a single volcanic center with an approximate base diameter of $25 \mathrm{~km}$, and like all of the seamounts drilled it has a flat summit. Site U1377 was placed near the middle of this small edifice (Fig. F62), away from its shelf edges and any packages of dipping volcaniclastics on its flanks. This approach is similar to that used at Sites U1375 and U1376 but contrary to that used at Sites U1372, U1373, and U1374, which targeted the volcaniclastic rocks from the flank sequences in particular. Our two attempts at drilling Site U1377 suffered from insta- 
bilities in the uppermost part of the seamount formation. As with drilling at Site U1375 on Achernar Guyot, these instabilities were caused by the predominance of more or less unconsolidated volcanic breccia in the sedimentary cover. As a result, drilling reached only 53.3 mbsf in Hole U1377A (16\% recovery) and 37 mbsf in Hole U1377B (39\% recovery). No logging could be carried out in these shallow holes.

Despite low recovery, Holes U1377A and U1377B provided enough core material to allow at least a partial reconstruction of the sedimentary cover on top of Hadar Guyot. This cover overlies an igneous basement of trachybasalt, a more evolved lithology than the alkalic basalt drilled at the other sites in the Louisville Seamount Trail (Fig. F63). Both holes start out with nannofossil foraminiferal ooze, followed by an older sedimentary cover including pelagic limestone and volcanic breccia. This middle-upper Eocene foraminiferal limestone contains abundant planktonic foraminifers, ferromanganese encrustations, and rare shallow-marine bioclasts and was likely deposited in a shallow-marine to hemipelagic-pelagic environment. The trachybasalt units in the igneous basement exhibit intervals of pronounced flow banding, suggesting that they formed as massive lava flows or smaller lobate flows. Lower in the sequence of Hole U1377B, however, much smaller individual cooling units with well-preserved curved glassy margins were encountered. These margins are diagnostic of small lobate flows or pillows and emplacement in a submarine environment.

\section{Lithostratigraphy and biostratigraphy}

Two units were recognized on the basis of macroand microscopic observations of the sediment (Fig. F63A). Unit I represents the uppermost sediment of Hadar Guyot and was recovered in Holes U1377A and $\mathrm{U} 1377 \mathrm{~B}$. The sediment is composed of nannofossil foraminiferal ooze, which strongly resembles the soft sediment recovered in the uppermost part of Sites U1372 on Canopus Guyot, U1374 on Rigil Guyot, and U1375 on Achernar Guyot. This ooze is considered to reflect recent pelagic sedimentation on top of the drilled seamount. Unit II corresponds to a few cuttings recovered in Section 330-U1377A-3R$\mathrm{CC}$ and 10 small ( $<20 \mathrm{~cm}$ thick) pieces recovered by drilling in situ sediment (in both Holes U1377A and U1377B) and the out-of-sequence material (caused by the partial collapse of Hole U1377B) of Core 330U1377A-3G. This unit also includes foraminiferal limestone with abundant planktonic foraminifers, some ferromanganese encrustations, and rare shallow-marine bioclasts (e.g., echinoderm fragments) (Figs. F64A, F65) that has been dated as middle-late Eocene. This limestone then seems to overlie an up- permost Paleocene to lower Eocene heterolithic multicolor basalt conglomerate, also with a few ferromanganese encrustations. The matrix of the conglomerate is composed of foraminiferal limestone with abundant planktonic foraminifers and sparse shallow-marine fossils (e.g., echinoderm fragments, larger foraminifers, shell fragments, and a gastropod). Faunal assemblages and sedimentary textures indicate that Unit II at Site U1377 represents one (or several) condensed section(s) likely to have been deposited in a shallow-marine to hemipelagicpelagic environment on top of Hadar Guyot. On the basis of preliminary age estimates, an unconformity representing $\sim 30$ m.y. exists between Units I and II.

\section{Igneous petrology}

Holes U1377A and U1377B penetrated $38.2 \mathrm{~m}$ and $27.9 \mathrm{~m}$ of igneous rocks after entering igneous basement at 15.1 mbsf and 9.1 mbsf, respectively (Fig. F63B). The igneous sequences were divided into 6 lithologic units in Hole U1377A and 18 lithologic units in Hole U1377B. The similarity of the rocks in both sequences led to the definition of only one stratigraphic unit in each hole (Unit III in both cases). The lithology in these two holes is broadly similar, consisting largely of aphyric trachybasalt, in places olivine-rich bands and, in Hole U1377B, intervals containing plagioclase-augite glomerocrysts. In Hole U1377A and the upper part of Hole U1377B the trachybasalt exhibits intervals of pronounced flow banding, suggesting that these parts of the successions formed as massive lava flows or smaller lobate flows (Fig. F64B, F64C). The lower part of the succession in Hole U1377B, however, consists of much smaller $(7 \mathrm{~cm}$ to $2.08 \mathrm{~m}$ ) individual cooling units with well-preserved curved glassy margins, diagnostic of small lobate flows or pillows and emplacement in a submarine environment. A curious feature of these margins is that in several instances the volcanic glass between adjacent pillows is seen to connect with the more massive interior of the unit below. It appears that lava in the still-molten interior of a pillow has broken out as a protrusion that filled the space between overlying pillows (Fig. F64D). Alternatively, magma may have been injected into a stack of pillows, but the similarity in appearance between the injected and pillow trachybasalt suggests that, in either case, both were part of the same eruptive event. The presence of glassy pillow margins that are distinct from the glass in the protrusions shows that the pillows must already have had glassy crusts when lava from below protruded into the space between them. In one case, fragments of the pillows are incorporated into the protrusion. Based on the very limited shipboard petrographic and geochemical in- 
vestigations possible at this late stage of the expedition, it seems likely that the magma represented by the rocks recovered at this site was generally alkalic and intermediate in composition. If postcruise petrographic and analytical studies confirm this, then the rocks recovered at Site U1377 will have the most evolved composition of all rocks drilled during Expedition 330 .

\section{Alteration petrology}

The rocks recovered from Holes U1377A and U1377B have undergone secondary alteration by low-temperature water-rock interactions and perhaps weathering (Fig. F66). The overall alteration of the volcanic rocks from Hole U1377A ranges from slight to high $(10 \%-$ $75 \%)$, whereas the rocks from Hole U1377B vary from moderate to complete (30\%-100\%). Brown to reddish-brown alteration indicates the prevalence of oxidizing conditions in both holes. Olivine is typically completely altered to white clay minerals in Hole U1377A and to iddingsite and Fe oxyhydroxides in Hole U1377B. Plagioclase is well preserved as phenocrysts and in the groundmass in several lithologic units in Hole U1377B. A few bands of relatively fresh volcanic glass are also present in margins of pillows or lava lobes toward the bottom of Hole U1377B. Alteration phases for both holes are primarily carbonates ( $\mathrm{Mg}$ calcite, siderite, and ankerite), white clay minerals, and Fe oxyhydroxides (goethite). Fe oxyhydroxides are also particularly abundant in veins in the rocks from both holes.

\section{Structural geology}

Structural features at Site U1377 are dominated by veins, vein networks, and vesicle bands. The highest vein density in Hole U1377A is at 15.1-16.6 mbsf (lithologic Unit 1), with 34 veins per meter, whereas most of the recovered intervals have 5-25 veins per meter. In Hole U1377B the maximum vein density is 26 veins per meter, which occurs at 20-21 mbsf (lithologic Unit 2), whereas other recovered intervals typically have lower values between 10 and 24 veins per meter. The veins in both holes have moderate to steep dips, and a single horizontal geopetal structure at 0.85 mbsf in Hole U1377B is evidence that this part of Hadar Guyot has not been tilted since deposition of the geopetal infilling material. Vesicle bands and chilled contacts in Hole U1377B are moderate to steep, with dips ranging from $45^{\circ}$ to $90^{\circ}$. Similarly, vesicle bands with either moderate or subhorizontal dips were recovered in Hole U1377A.

\section{Geochemistry}

Major and trace element concentrations were measured for one altered $(\mathrm{LOI}=3.0 \mathrm{wt} \%)$ igneous sample from Unit III of Hole U1377A. This sample is the most siliceous rock analyzed during Expedition 330, with $55.00 \mathrm{wt} \% \mathrm{SiO}_{2}$. It also has the highest $\mathrm{Al}_{2} \mathrm{O}_{3}$, lowest $\mathrm{Fe}_{2} \mathrm{O}_{3}{ }^{\top}$ (total iron as $\mathrm{Fe}_{2} \mathrm{O}_{3}$ ), and second-lowest $\mathrm{MgO}$ and $\mathrm{CaO}$ concentrations. In a diagram of total alkalis $\left(\mathrm{Na}_{2} \mathrm{O}+\mathrm{K}_{2} \mathrm{O}\right)$ vs. $\mathrm{SiO}_{2}$, data for the sample fall in the field of basaltic trachyandesite, near the dividing line between alkalic and tholeiitic compositions. However, alteration may have modified the rock's $\mathrm{K}_{2} \mathrm{O}$ and perhaps $\mathrm{Na}_{2} \mathrm{O}$ concentrations, whereas incompatible elements less susceptible to alteration are near the high end of values measured for other Expedition 330 rocks. This suggests that the sample represents highly differentiated transitional to alkalic magma that possibly evolved from a composition rather similar to that of most Expedition 330 basalt. However, other characteristics of the sample complicate any simple explanation of its origin. In particular, concentrations of the compatible trace elements $\mathrm{Cr}, \mathrm{Ni}$, and $\mathrm{Co}$ are anomalously high $(686,421$, and 122 ppm, respectively). This unusual combination of characteristics suggests that the sample may represent an evolved magma that was contaminated by a small amount of olivine-rich material from a mush zone or ultramafic wall rock during ascent.

\section{Physical properties}

Physical property characterization was conducted for material recovered from Holes U1377A and U1377B. The data sets are mutually consistent and fall within the ranges expected on the basis of identified lithologies. Several distinct intervals of high magnetic susceptibility in excess of $2.5 \times 10^{-2}$ SI were observed in the aphyric trachybasalt. In addition, the level of NGR is higher in both Holes U1377A and U1377B than at other Expedition 330 sites. This likely results from a combination of increased alteration and more evolved magma composition at this site. Increased alteration is also seen in the strongly red and yellow color reflectance spectrum in Hole U1377B. Densities and $P$-wave velocities are consistently lower at this site than they are for lava at earlier sites, possibly reflecting the more evolved composition.

\section{Paleomagnetism}

The NRM intensity of archive-half cores from Site $\mathrm{U} 1377$ is typically $<1 \mathrm{~A} / \mathrm{m}$, notably lower than that of other guyots sampled during Expedition 330. This lower value presumably reflects the higher degree of alteration observed. Both holes at Site U1377 had only shallow penetration and, particularly for Hole U1377A, poor core recovery. Nonetheless, samples from both holes appear to have positive inclinations, indicating Southern Hemisphere reversed polarity. Shipboard sampling at these holes was limited be- 
cause of the short time remaining for shipboard analysis at the end of the expedition (Fig. F67).

\section{Microbiology}

Two whole-round samples (8-11 cm long) were collected for microbiological analysis: moderately olivine-phyric trachybasalt from Hole U1377A and aphyric trachybasalt from Hole U1377B. Both samples were preserved for shore-based cell counting, DNA analyses, and $\delta^{34} \mathrm{~S}$ and $\delta^{13} \mathrm{C}$ analyses. The sample from Hole U1377A was used to inoculate culturing experiments with nine different types of cultivation media targeting sulfur- and iron-cycling microbes and general heterotrophic bacteria. Both samples were used to set up stable isotope addition bioassays to determine rates of carbon and nitrogen utilization by subsurface microbes at Hadar Guyot.

\section{Preliminary scientific assessment}

Expedition 330 to the Louisville Seamount Trail was a record-breaking hard rock expedition with an exceptionally high recovery of rocks of surprising freshness considering their age and long-term submarine residence. In total, $1114 \mathrm{~m}$ of sediment and igneous basement at five seamounts was cored, and $806 \mathrm{~m}$ was recovered (average $=72.4 \%$ ) $($ Table T3). At Site U1374 on Rigil Guyot, $522 \mathrm{~m}$ was drilled with a record-breaking $87.7 \%$ recovery. At all sites, most of the cored material is characterized by low degrees of alteration, providing a large quantity of samples of mostly well-preserved basalt containing, for example, pristine olivine crystals, fresh volcanic glass, unaltered plagioclase, and in one case mantle xenoliths and xenocrysts.

Extensive description and shipboard measurements of the recovered cores and downhole logging (at two sites) revealed some surprises about how the Louisville volcanoes were constructed. Although these flat-topped guyots once were volcanic islands like the Hawaiian and Easter Islands, drilling results provided only sparse signs of subaerial volcanism. Rather, primarily shallow to deeper submarine volcanic sequences were recovered after drilling through the thin sedimentary covers that now overlie these volcanoes. The Louisville volcanoes thus seem to have been smaller islands that remained above sea level for only a relatively short time before wave erosion planed off the upper part of the volcanoes to make them into flat-topped seamounts (i.e., guyots) at the end of their constructional phase. In the case of Site U1376 on Burton Guyot, evidence was found of an extensive algal reef and posterosional volcanism following the initial subsidence of this formerly volcanic island.
The good core quality provides a wide range of valuable seamount material for shore-based studies, including

- Many different kinds of unaltered alkaline basalt;

- Melt inclusions in fresh olivine crystals;

- Volcanic glass found on water-quenched contacts of lava flows and as part of hyaloclastite breccia;

- High-Mg olivine, clinopyroxene, and plagioclase phenocrysts;

- Carbonate, zeolite, and celadonite alteration minerals; and

- Various micro- and macrofossils.

The large quantity and excellent quality of the recovered sample material will allow all of the scientific objectives of this expedition to be addressed, including

1. Constraining the paleolatitude history of the Louisville hotspot between 80 and $50 \mathrm{Ma}$;

2. Reconstructing the age systematics along the Louisville Seamount Trail;

3. Characterizing the geochemical evolution of the Louisville mantle source;

4. Testing the relation between the Louisville hotspot and the 120 Ma Ontong Java Plateau;

5. Determining the degree, potential temperature, and depth at which partial melting occurred for Louisville magmas;

6. Adding crucial paleoceanography and paleoclimate data at $40^{\circ}-50^{\circ} \mathrm{S}$ paleolatitudes in the Southern Ocean; and

7. Exploring the unique geomicrobiology and fossil microbial traces in the igneous basement of the Louisville Seamounts.

\section{Paleolatitude record of the Louisville hotspot}

The main objective of Expedition 330 was to core deep in the igneous basement of several seamounts in the Louisville Seamount Trail in order to establish a record of the past motion of the Louisville hotspot between 80 and $50 \mathrm{Ma}$. This record will show whether the Louisville hotspot has undergone a large $\sim 15^{\circ}$ shift in paleolatitude, similar to the shift documented for the Hawaiian hotspot (Tarduno et al., 2003). If the Louisville and Hawaiian hotspots did not move in concert over time, it instead will indicate a considerable interhotspot motion between both primary Pacific hotspots, as predicted by mantle flow models (Steinberger et al., 2004; Koppers et al., 2004). Comparison of the Louisville and Hawaiian hotspots thus is of fundamental importance in determining whether these two primary hotspots have moved coherently or not, to understanding the 
nature of hotspots and convection in the Earth's mantle, and to evaluating the possibility of true polar wander.

Accurate determination of the paleolatitude record for the five seamounts drilled and comparison of these records to the current $\sim 50^{\circ}-51^{\circ} \mathrm{S}$ location of the Louisville hotspot requires recovery of a sufficient number of time-independent lava flows at each drill site. Preferably, these lava flows should have erupted over a period of perhaps tens of thousands to a few million years in order to effectively average out paleosecular variation of the Earth's magnetic field. Drilling during Expedition 330 resulted in a large amount of in situ lava flows, pillow basalts, and other types of volcanic products, such as autobrecciated lava flows, intrusive sheets or dikes, and peperites. In particular, the deeper holes on Canopus and Rigil Guyots, the two oldest seamounts drilled in the Louisville Seamount Trail, resulted in adequate numbers of in situ lava flows with (for now) eruption ages estimated to be $\sim 75-77$ and $72-73 \mathrm{Ma}$, respectively. Remarkably, all drill sites also recovered large quantities of hyaloclastites, volcanic sandstone, and basaltic breccia, which in many cases show consistent paleomagnetic inclinations when compared to lava flows bracketing these units, as shown by 9267 good-quality remanent magnetization measurements taken at $2 \mathrm{~cm}$ spacing from archive-half cores and by experiments on an additional 409 discrete shipboard samples that passed quality-control filters. However, most importantly, almost without exception the half-core data are in good agreement with the discrete measurements using either alternatingfield or thermal demagnetization. For Site U1374 on Rigil Guyot a magnetic polarity reversal was also observed in the cored sequence, providing antipodal inclinations for both the normal and reversed polarity intervals cored. Overall, this is very promising for determining a reliable paleolatitude record for the Louisville Seamounts, but in order to achieve that goal detailed postexpedition paleomagnetic experiments need to be carried out on multiple ( $>4$ per flow) discrete samples taken from all in situ lava flow units and from any other suitable lithology that may also reliably retain directional information. This will provide a more accurate and precise estimate of these paleolatitudes, particularly after a range of rock magnetic experiments have been carried out to study the character of the remanent magnetization held within both the basaltic lava flows and the large quantity of volcaniclastic sediments.

Importantly, analysis of the paleolatitude record for the Louisville hotspot will be supplemented by downhole logging data collected with the Göttingen Borehole Magnetometer (GBM). This third-party tool (Steveling et al., 2003) was run twice in Hole U1374A at Rigil Guyot and once in Hole U1376A at Burton Guyot, collecting continuous three-component magnetic data, together with the tool's rotation history, using three built-in optical gyros. The data quality was significantly improved by inserting a truly nonmagnetic aluminum sinker bar directly above the GBM to isolate the tool from other magnetic parts higher up in the tool string. This provided a highprecision record of the magnetic field inside the borehole that with the continuously recorded rotation history of the GBM can be accurately reoriented and translated into geographic coordinates, allowing for in situ determination of inclinations and declinations of the seamount formations. This set of measurements will provide an independent record of the paleolatitude history of the Louisville hotspot and unique estimates of the past virtual geomagnetic pole positions of the Pacific plate on which the Louisville Seamounts formed.

\section{Age systematics along the Louisville Seamount Trail}

Radiometric dating of Louisville Seamount rocks using ${ }^{40} \mathrm{Ar} /{ }^{39} \mathrm{Ar}$ geochronological techniques is a crucial objective of Expedition 330 because it will provide the necessary time framework for determining the volcanic history of individual seamounts and the age progression along the Louisville Seamount Trail. In turn, this age information will aid in determining an accurate paleolatitude history for the Louisville hotspot and will be crucial in evaluating the possible relative motion between different hotspot systems. However, high-precision age measurements are necessary to resolve, for example, the total time of volcanic activity captured between the lowest and highest in situ lava flows at each drilled seamount site. During Expedition 330 a large amount of relatively unaltered basalt was recovered with $\mathrm{K}_{2} \mathrm{O}$ concentrations between 0.3 and $1.4 \mathrm{wt} \%$ and low weight loss on ignition of mostly $<3 \%$. The ${ }^{40} \mathrm{Ar} /{ }^{39} \mathrm{Ar}$ geochronology of this basalt will therefore likely yield ages with a precision of $0.2-0.4 \mathrm{Ma}(2 \sigma)$, which will allow the duration of and potential time gaps between multiple eruptive units at each single drill site to be resolved.

Paleontological evidence from calcareous nannofossils and planktonic foraminifers and the occurrence of macrofossils in the sediments overlying the igneous basement provide strong indications that the cored lava is as old as that predicted by previous studies (Koppers et al., 2004) and in some cases apparently even older. This means that in all cases the main constructional phase of the drilled seamount volcanoes can be age-dated, which in turn will provide the age-progressive timing required for detailed 
analyses of the paleolatitude record, refinement of the age progression along the Louisville Seamount Trail, and geodynamic modeling of the past motion of the Louisville mantle plume relative to the Hawaiian hotspot.

\section{Geochemical evolution of the Louisville Seamounts}

Expedition 330 also aimed to provide an improved understanding of the magmatic evolution and melting processes that have produced the Louisville volcanoes. Existing dredge data suggest that the mantle source of the Louisville hotspot has been remarkably homogeneous for as long as 80 m.y. (Cheng et al., 1987; Hawkins et al., 1987) and that the Louisville volcanoes might be typified by an entirely alkalic shield-building stage, in contrast to the characteristic tholeiitic shield stage of the Hawaiian-Emperor volcanoes (Hawkins et al., 1987). Shipboard chemical analyses show that the drilled rocks of the Louisville Seamounts have all alkalic or transitional compositions and that indeed tholeiitic basalt was not encountered at any of the drill sites. Trace element shipboard data show that the drilled volcanic rocks fall within the compositional fields defined by previous studies on dredge samples, thus reinforcing the remarkably homogeneous character of this primary hotspot. However, a full range of shore-based analyses including isotope studies is needed to further characterize this unique hotspot system and to define the "true" compositional heterogeneity in the mantle source from which Louisville magmas have been generated.

Fresh olivine phenocrysts were recovered at four of the six Expedition 330 drill sites, which will allow measurement of ${ }^{3} \mathrm{He} /{ }^{4} \mathrm{He}$, an important noble gas isotope ratio that has never before been measured for the Louisville Seamount Trail but which may indicate whether this hotspot has a shallow- or deepmantle origin. The fresh olivines will also allow melt inclusions trapped in these phenocrysts to be analyzed for primitive magma compositions and to provide insights into the mantle sources of these Louisville magmas. Because these inclusions often span a range of compositions wider than those exhibited by groundmass glass or bulk rock (Frezzotti, 2001; Danyushevsky et al., 2002), melt inclusion studies will complement the bulk-rock analyses of Louisville basaltic rocks. In addition, melt inclusions may preserve initial magma volatiles and the degassing path undertaken by the magma (Wallace, 2005). Finally, the Louisville basalts are an excellent candidate for determining Mg-Fe compositions of olivine phenocrysts and melt inclusions therein, which in turn may yield information about the source tempera- tures by relating the $\mathrm{Mg} / \mathrm{Fe}$ ratio of olivine directly to that of the liquid from which it crystallized (Putirka et al., 2007).

\section{Relation between the Louisville hotspot and the Ontong Java Plateau}

The Ontong Java Plateau is proposed to have been formed by the initial plume-head phase of the Louisville hotspot (e.g., Mahoney and Spencer, 1991; Tarduno et al., 1991). Results from Expedition 330 postexpedition studies will provide a much more rigorous test of the potential genetic relationship between Louisville and the formation of the Ontong Java Plateau by looking for conjunctions in the Louisville and Ontong Java paleolatitude histories and geochemical signatures. Even though this is a secondary objective that can be addressed only after the three primary objectives described above have been resolved, this test nevertheless will provide key insights in the mantle plume debate, especially for the plume-head-plume-tail model.

\section{Paleoceanography and paleoclimate at high southern paleolatitudes}

During Expedition 330 several intervals of carbonate were cored from the Louisville Seamounts, in particular at Site U1376 on Burton Guyot, where a $\sim 15 \mathrm{~m}$ thick algal limestone reef was cored (66\% recovery). On three of the other four seamounts drilled during Expedition 330, condensed pelagic limestone intervals were also recovered, but these did not exceed 30 $\mathrm{cm}$ in thickness. Nonetheless, these limestones provide valuable insights in the paleoclimate record at high $\left(\sim 50^{\circ}\right)$ southern latitudes since the Cretaceous, in particular because the well-preserved Site U1376 limestone was likely formed toward the end of the Cretaceous or in the early Paleogene. It therefore might provide fundamental constraints on the ancient sea-surface temperatures and climate transitions in the greenhouse interval that are characteristic of this time period. Paleolatitudes, timing of formation, and eventually the drowning of such carbonate banks may provide evidence for a temperate climate during past warm periods at high latitudes in the southern Pacific Ocean, where paleoclimate data are mostly lacking (Premoli Silva et al., 1995; Wilson et al., 1998; Jenkyns and Wilson, 1999).

\section{Geomicrobiology and fossil microbial traces}

During Expedition 330, more than 60 microbiology samples were collected from four seamounts ranging in age between 80 and $50 \mathrm{Ma}$ and from a maximum depth of 516 mbsf. This collection of igneous basement samples for microbiology is the largest of any 
hard rock expedition, most of which have focused particularly on young mid-ocean-ridge settings. Expedition 330 thus provides an excellent opportunity to study both living and extant microbial residents in the old subseafloor volcanic rocks that make up the Louisville Seamounts. Differences in microbial population between overlying (pelagic) sediments and volcaniclastic layers and the basaltic basement are of great interest, as is variation between different kinds of lava flows, with depth into the seamount structures, and between seamounts of different age. Because of the high number of fresh volcanic glass occurrences at most Expedition 330 drill sites, the search for and study of microbial fossil traces will provide new information on the activity of and boring patterns generated by glass-metabolizing microorganisms (Thorseth et al., 1995; Fisk et al., 1998; Furnes et al., 2001) in the largely unstudied seamount subsurface environment.

\section{References}

Adams, C.G., 1967. Tertiary foraminifera in the Tethyan, American and Indo-Pacific provinces. In Adams, C.G., and Ager, D.V. (Eds.), Aspects of Tethyan Biogeography: A Symposium: London (Systematics Association), 7:195217.

Adams, C.G., 1983. Speciation, phylogenesis, tectonism, climate and eustasy: factors in the evolution of Cenozoic large foraminiferal bioprovinces. In Sims, R.W., Price, J.H., and Whalley, P.E.S. (Eds.), Evolution, Time and Space: Emergence of the Biosphere. Syst. Assoc. Spec. Vol. Ser., 23:255-289.

Allègre, C.J., Staudacher, T., Sarda, P., and Kurz, M., 1983. Constraints on evolution of Earth's mantle from rare gas systematics. Nature (London, U. K.), 303(5920):762766. doi:10.1038/303762a0

Alt, J.C., and Teagle, D.A.H., 1999. The uptake of carbon during alteration of ocean crust. Geochim. Cosmochim. Acta, 63(10):1527-1535. doi:10.1016/S00167037(99)00123-4

Alt, J.C., and Teagle, D.A.H., 2003. Hydrothermal alteration of upper oceanic crust formed at a fast-spreading ridge: mineral, chemical, and isotopic evidence from ODP Site 801. Chem. Geol., 201(3-4):191-211. doi:10.1016/S0009-2541(03)00201-8

Antretter, M., Riisager, P., Hall, S., Zhao, X., and Steinberger, B., 2004. Modeled palaeolatitudes for the Louisville hot spot and the Ontong Java Plateau. In Fitton, J.G., Mahoney, J.J., Wallace, P.J., and Saunders, A.D. (Eds.), Origin and Evolution of the Ontong Java Plateau. Geol. Soc. Spec. Publ., 229(1):21-30. doi:10.1144/ GSL.SP.2004.229.01.03

Antretter, M., Steinberger, B., Heider, F., and Soffel, H., 2002. Paleolatitudes of the Kerguelen hotspot: new paleomagnetic results and dynamic modeling. Earth Planet. Sci. Lett., 203(2):635-650. doi:10.1016/S0012821X(02)00841-5
Bach, W., Peucker-Ehrenbrink, B., Hart, S.R., and Blusztajn, J.S., 2003. Geochemistry of hydrothermally altered oceanic crust: DSDP/ODP Hole 504B-implications for seawater-crust exchange budgets and $\mathrm{Sr}$ - and $\mathrm{Pb}$-isotopic evolution of the mantle. Geochem., Geophys., Geosyst., 4(3):8904-8932. doi:10.1029/2002GC000419

Barrera, E., and Savin, S.M., 1999. Evolution of Campanian-Maastrichtian marine climates and oceans. In Barrera, E., and Johnson, C.C. (Eds.), Evolution of the Cretaceous Ocean-Climate System. Spec. Pap.-Geol. Soc. Am., 332:245-282. doi:10.1130/0-8137-2332-9.245

Bartetzko, A., Paulick, H., Iturrino, G., and Arnold, J., 2003. Facies reconstruction of a hydrothermally altered dacite extrusive sequence: evidence from geophysical downhole logging data (ODP Leg 193). Geochem., Geophys., Geosyst., 4(10):1087-1110. doi:10.1029/ 2003GC000575

Beier, C., Vanderkluysen, L., Regelous, M., Mahoney, J.J., and Garbe-Schönberg, D., 2011. Lithospheric control on geochemical composition along the Louisville Seamount Chain. Geochem., Geophys., Geosyst., 12:Q0AM01. doi:10.1029/2011GC003690

Besse, J., and Courtillot, V., 1991. Revised and synthetic apparent polar wander paths of African, Eurasian, North American and Indian plates, and true polar wander since 200 Ma. J. Geophys. Res., [Solid Earth], 96(B3):40294051. doi:10.1029/90JB01916

Besse, J., and Courtillot, V., 2002. Apparent and true polar wander and the geometry of the geomagnetic field over the last 200 Myr. J. Geophys. Res. [Solid Earth], 107(B11):2300-2330. doi:10.1029/2000JB000050

Brandon, A.D., Norman, M.D., Walker, R.J., and Morgan, J.W., 1999. ${ }^{186} \mathrm{Os}^{-187}$ Os systematics of Hawaiian picrites. Earth Planet. Sci. Lett., 174(1-2):25-42. doi:10.1016/ S0012-821X(99)00251-4

Butler, R.F., 1992. Paleomagnetism: Magnetic Domains to Geologic Terranes: Boston (Blackwell).

Cande, S.C., and Kent, D.V., 1995. Revised calibration of the geomagnetic polarity timescale for the Late Cretaceous and Cenozoic. J. Geophys. Res., [Solid Earth], 100(B4):6093-6095. doi:10.1029/94JB03098

Cande, S.C., Raymond, C.A., Stock, J., and Haxby, W.F., 1995. Geophysics of the Pitman Fracture Zone and Pacific-Antarctic plate motions during the Cenozoic. Science, 270(5238):947-953. doi:10.1126/science.270.5238.947

Cheng, Q., Park, K.-H., Macdougal, J.D., Zindler, A., Lugmair, G.W., Hawkins, J., Lonsdale, P., and Staudigel, H., 1987. Isotopic evidence for a hot spot origin of the Louisville Seamount Chain. In Keating, B.H., Fryer, P., Batiza, R., and Boehlert, G. (Eds.), Seamounts, Islands and Atolls. Geophys. Monogr., 43:283-296.

Clague, D.A., and Dalrymple, G.B., 1988. Age and petrology of alkalic postshield and rejuvenated-stage lava from Kauai, Hawaii. Contrib. Mineral. Petrol., 99(2):202218. doi:10.1007/BF00371461

Clouard, V., and Bonneville, A., 2001. How many Pacific hotspots are fed by deep-mantle plumes? Geology, 29(8):695-698. doi:10.1130/00917613(2001)029<0695:HMPHAF>2.0.CO;2 
Constable, C., and Johnson, C., 2005. A paleomagnetic power spectrum. Phys. Earth Planet. Int., 153(1-3):61-73. doi:10.1016/j.pepi.2005.03.015

Contreras-Reyes, E., Grevemeyer, I., Watts, A.B., Planert, L., Flueh, E.R., and Peirce, C., 2010. Crustal intrusion beneath the Louisville hotspot track. Earth Planet. Sci. Lett., 289(3-4):323-333. doi:10.1016/

j.epsl.2009.11.020

Corfield, R.M., and Cartlidge, J.E., 1992. Oceanographic and climatic implications of the Paleocene carbon isotope maximum. Terra Nova, 4(4):443-455. doi:10.1111/ j.1365-3121.1992.tb00579.x

Corfield, R.M., and Norris, R.D., 1996. Deep water circulation in the Paleogene Ocean. In Knox, R.W., Corfield, R.M., and Dunay, R.E. (Eds.), Correlation of the Early Paleogene in Northwest Europe. Geol. Soc. Spec. Publ., 101(1):443-456. doi:10.1144/GSL.SP.1996.101.01.21

Courtier, A.M., Jackson, M.G., Lawrence, J.F., Wang, Z., Lee, C.-T.A., Halama, R., Warren, J.M., Workman, R., Xu, W., Hirschmann, M.M., Larson, A.M., Hart, S.R., Lithgow-Bertelloni, C., Stixrude, L., and Chen, W.-P., 2007. Correlation of seismic and petrologic thermometers suggests deep thermal anomalies beneath hotspots. Earth Planet. Sci. Lett., 264(1-2):308-316. doi:10.1016/ j.epsl.2007.10.003

Courtillot, V., Davaille, A., Besse, J., and Stock, J., 2003. Three distinct types of hotspots in Earth's mantle. Earth Planet. Sci. Lett., 205(3-4):295-308. doi:10.1016/S0012821X(02)01048-8

Cowen, J.P., Giovannoni, S.J., Kenig, F., Johnson, H.P., Butterfield, D., Rappé, M.S., Hutnak, M., and Lam, P., 2003. Fluids from aging ocean crust that support microbial life. Science, 299(5603):120-123. doi:10.1126/science. 1075653

Danyushevsky, L.V., Sokolov, S., and Falloon, T.J., 2002. Melt inclusions in olivine phenocrysts: using diffusive re-equilibration to determine the cooling history of a crystal, with implications for the origin of olivine-phyric volcanic rocks. J. Petrol., 43(9):1651-1671. doi:10.1093/petrology/43.9.1651

Davaille, A., Girard, F., and Le Bars, M., 2002. How to anchor hotspots in a convecting mantle? Earth Planet. Sci. Lett., 203(2):621-634. doi:10.1016/S0012821X(02)00897-X

Davies, D.R., and Davies, J.H., 2009. Thermally driven mantle plumes reconcile multiple hotspot observations. Earth Planet. Sci. Lett., 278(1-2):50-54. doi:10.1016/ j.epsl.2008.11.027

Devey, C.W., Lackschewitz, K.S., Mertz, D.F., Bourdon, B., Cheminée, J.-L., Dubois, J., Guivel, C., Hékinian, R., and Stoffers, P., 2003. Giving birth to hotspot volcanoes: distribution and composition of young seamounts from the seafloor near Tahiti and Pitcairn islands. Geology, 31(5):395-398. doi:10.1130/0091-

7613(2003)031<0395:GBTHVD>2.0.CO;2

DiVenere, V., and Kent, D.V., 1999. Are the Pacific and Indo-Atlantic hotspots fixed? Testing the plate circuit through Antarctica. Earth Planet. Sci. Lett., 170(12):105-117. doi:10.1016/S0012-821X(99)00096-5
Doubrovine, P.V., and Tarduno, J.A., 2008a. A revised kinematic model for the relative motion between Pacific oceanic plates and North America since the Late Cretaceous. J. Geophys Res., [Solid Earth], 113(B12):B12101B12120. doi:10.1029/2008JB005585

Doubrovine, P.V., and Tarduno, J.A., 2008b. Linking the Late Cretaceous to Paleogene Pacific plate and the Atlantic bordering continents using plate circuits and paleomagnetic data. J. Geophys Res., [Solid Earth], 113(B7):B07104-B07127. doi:10.1029/2008JB005584

Downey, N.J., Stock, J.M., Clayton, R.W., and Cande, S.C., 2007. History of the Cretaceous Osbourn spreading center. J. Geophys. Res., [Solid Earth], 112(B4):B04102B04119. doi:10.1029/2006JB004550

Duncan, R., Arndt, N., Hanyu, T., Harada, Y., Harpp, K., Hoernle, K., Kellogg, L., Kent, D., Koppers, A., Sager, W., Steinberger, B., Tarduno, J., and Xu, Y.-G., 2007. Report from the Hotspot Geodynamics Detailed Planning Group [from Hotspot Geodynamics Detailed Planning Group Meeting, University of Hawaii, Manoa, 12 and 13 January 2007].

Duncan, R.A., and Keller, R.A., 2004. Radiometric ages for basement rocks from the Emperor Seamounts, ODP Leg 197. Geochem., Geophys., Geosyst., 5(8):Q08L03-Q08L15. doi:10.1029/2004GC000704

Duncan, R.A., Tarduno, J.A., and Scholl, D.W., 2006. Leg 197 synthesis: southward motion and geochemical variability of the Hawaiian hotspot. In Duncan, R.A., Tarduno, J.A., Davies, T.A., and Scholl, D.W. (Eds.), Proc. ODP, Sci. Results, 197: College Station, TX (Ocean Drilling Program), 1-39. doi:10.2973/ odp.proc.sr.197.001.2006

Eickmann, B., Bach, W., and Peckmann, J., 2009. Authigenesis of carbonate minerals in modern and Devonian ocean-floor hard rocks. J. Geol., 117(3):307-323. doi:10.1086/597362

Ellam, R.M., 1992. Lithospheric thickness as a control on basalt geochemistry. Geology, 20(2):153-156. doi:10.1130/0091-7613(1992)020<0153:LTA$\mathrm{ACO}>2.3 . \mathrm{CO} ; 2$

Epp, D., 1978. Relationships between plate/plate and plate/mantle motion in the Pacific. Eos, Trans. Am. Geophys. Union, 59(12):1203.

Farley, K.A., and Neroda, E., 1998. Noble gases in the Earth's mantle. Annu. Rev. Earth Planet. Sci., 26(1):189218. doi:10.1146/annurev.earth.26.1.189

Fisk, M.R., Giovannoni, S.J., and Thorseth, I.H., 1998. Alteration of oceanic volcanic glass: textural evidence of microbial activity. Science, 281(5379):978-980. doi:10.1126/science.281.5379.978

Foulger, G.R., and Anderson, D.L., 2005. A cool model for the Iceland hotspot. J. Volcanol. Geotherm. Res., 141(12):1-22. doi:10.1016/j.jvolgeores.2004.10.007

Frezzotti, M.-L., 2001. Silicate-melt inclusions in magmatic rocks: applications to petrology. Lithos, 55(1-4):273299. doi:10.1016/S0024-4937(00)00048-7

Furnes, H., Staudigel, H., Thorseth, I.H., Torsvik, T., Muehlenbachs, K., and Tumyr, O., 2001. Bioalteration of basaltic glass in the oceanic crust. Geochem., Geophys., Geosyst., 2(8):1049-1078. doi:10.1029/2000GC000150 
Gaillot, P., Einaudi, F., Stoll, J., and Leven, M., 2004. General-purpose inclinometry modules in highly magnetized formations: are borehole wall microresistivity images properly oriented? In Duncan, R.A., Tarduno, J.A., Davies, T.A., and Scholl, D.W. (Eds.), Proc. ODP, Sci. Results, 197: College Station, TX (Ocean Drilling Program), 1-22. doi:10.2973/odp.proc.sr.197.005.2004

Goldreich, P., and Toomre, A., 1969. Some remarks on polar wandering. J. Geophys. Res., [Solid Earth], 74(10):2555-2567. doi:10.1029/JB074i010p02555

Gordon, R.G., 1987. Polar wandering and paleomagnetism. Annu. Rev. Earth Planet. Sci., 15:567-593. doi:10.1146/annurev.ea.15.050187.003031

Graham, D.W., 2002. Noble gas isotope geochemistry of mid-ocean ridge and ocean island basalts: characterization of mantle source reservoirs. In Porcelli, D., Wieler, R., and Ballentine, C. (Eds.), Noble Gases in Geochemistry and Cosmochemistry. Rev. Mineral. Geochem., 47(1):247-317. doi:10.2138/rmg.2002.47.8

Grevemeyer, I., and Flüh, E.R., 2008. Cruise Report SO195: Tonga Thrust earthquake asperity at Louisville Ridge. IFM-GEOMR Rep., 14.

Hauri, E., 2002. SIMS analysis of volatiles in silicate glasses, 2: isotopes and abundances in Hawaiian melt inclusions. Chem. Geol., 183(1-4):115-141.doi:10.1016/ S0009-2541(01)00374-6

Hawkins, J.W., Lonsdale, P., and Batiza, R., 1987. Petrologic evolution of the Louisville Seamount Chain. In Keating, B.H., Fryer, P., Batiza, R., and Boehlert, G.W. (Eds.), Seamounts, Islands, and Atolls. Geophys. Monogr., 43:235254.

Hoernle, K., Werner, R., Phipps Morgan, J., Garbe-Schönberg, D., Bryce, J., and Mrazek, J., 2000. Existence of complex spatial zonation in the Galápagos plume. Geology, 28(5):435-438. doi:10.1130/0091-

7613(2000)028<0435:EOCSZI >2.3.CO;2

Huber, B.T., Hodell, D.A., and Hamilton, C.P., 1995. Middle-Late Cretaceous climate of the southern high latitudes: stable isotopic evidence for minimal equator-topole thermal gradients. Geol. Soc. Am. Bull.,

107(10):1164-1191. doi:10.1130/

0016-7606(1995)107<1164:MLCCOT>2.3.CO;2

Inagaki, F., Nunoura, T., Nakagawa, S., Teske, A., Lever, M., Lauer, A., Suzuki, M., Takai, K., Delwiche, M., Colwell, F.S., Nealson, K.H., Horikoshi, K., D'Hondt, S., and Jørgensen, B.B., 2006. Biogeographical distribution and diversity of microbes in methane hydrate-bearing deep marine sediments on the Pacific Ocean margin. Proc. Natl. Acad. Sci. U. S. A., 103(8):2815-2820. doi:10.1073/ pnas.0511033103

Inokuchi, H., and Heider, F., 1992. Paleolatitude of the southern Kerguelen Plateau inferred from the paleomagnetic study of Late Cretaceous basalts. In Wise, S.W., Jr., Schlich, R., et al., Proc. ODP, Sci. Results, 120: College Station, TX (Ocean Drilling Program), 89-96. doi:10.2973/odp.proc.sr.120.129.1992

Ito, G., and Mahoney, J.J., 2005. Flow and melting of a heterogeneous mantle: 1 . Method and importance to the geochemistry of ocean island and mid-ocean ridge basalts. Earth Planet. Sci. Lett., 230(1-2):29-46.

doi:10.1016/j.epsl.2004.10.035

Ito, H., Nogi, Y., and Larson, R.L., 1995. Magnetic reversal stratigraphy of Jurassic oceanic crust from Hole 801C downhole magnetometer measurements. In Haggerty, J.A., Premoli Silva, I., Rack, F., and McNutt, M.K. (Eds.), Proc. ODP, Sci. Results, 144: College Station, TX (Ocean Drilling Program), 641-647. doi:10.2973/ odp.proc.sr.144.024.1995

Ivarsson, M., Lindblom, S., Broman, C., and Holm, N.G., 2008. Fossilized microorganisms associated with zeolite-carbonate interfaces in sub-seafloor hydrothermal environments. Geobiology, 6(2):155-170. doi:10.1111/ j.1472-4669.2007.00139.x

Jenkyns, H.C., and Wilson, P.A., 1999. Stratigraphy, palaeoceanography, and evolution of Cretaceous Pacific guyots: relics from a greenhouse Earth. Am. J. Sci., 299(5):341-392. doi:10.2475/ajs.299.5.341

Keller, R.A., Graham, D.W., Farley, K.A., Duncan, R.A., and Lupton, J.E., 2004. Cretaceous-to-recent record of elevated ${ }^{3} \mathrm{He} /{ }^{4} \mathrm{He}$ along the Hawaiian-Emperor volcanic chain. Geochem., Geophys., Geosyst., 5(12):Q12L05Q12L14. doi:10.1029/2004GC000739

Kent, A.J.R., 2008. Melt inclusions in basaltic and related volcanic rocks. Rev. Mineral. Geochem., 69(1):273-331. doi:10.2138/rmg.2008.69.8

Kerr, B.C., Scholl, D.W., and Klemperer, S.L., 2006. Data report: seismic reflection surveys of the Emperor Seamounts: ODP Leg 197. In Duncan, R.A., Tarduno, J.A., Davies, T.A., and Scholl, D.W. (Eds.), Proc. ODP, Sci. Results, 197: College Station, TX (Ocean Drilling Program), 1-17. doi:10.2973/odp.proc.sr.197.006.2006

Klootwijk, C.T., Gee, J.S., Peirce, J.W., and Smith, G.M., 1991. Constraints on the India-Asia convergence: paleomagnetic results from Ninetyeast Ridge. In Weissel, J., Peirce, J., Taylor, E., Alt, J., et al., Proc. ODP, Sci. Results, 121: College Station, TX (Ocean Drilling Program), 777882. doi:10.2973/odp.proc.sr.121.121.1991

Kono, M., 1980. Magnetic properties of DSDP Leg 55 basalts. In Jackson, E.D., Koizumi, I., et al., Init. Repts. DSDP, 55: Washington, DC (U.S. Govt. Printing Office), 723-736. doi:10.2973/dsdp.proc.55.134.1980

Koppers, A.A.P., Duncan, R.A., and Steinberger, B., 2004. Implications of a nonlinear ${ }^{40} \mathrm{Ar} /{ }^{39} \mathrm{Ar}$ age progression along the Louisville Seamount Trail for models of fixed and moving hot spots. Geochem., Geophys., Geosyst., 5(6):Q06L02-Q06L23. doi:10.1029/2003GC000671

Koppers, A.A.P., Gowen, M.D., Colwell, L.E., Gee, J.S., Lonsdale, P.F., Mahoney, J.J., and Duncan, R.A., 2011. New ${ }^{40} \mathrm{Ar} /{ }^{39} \mathrm{Ar}$ age progression for the Louisville hotspot trail and implications for inter-hotspot motion. Geochem., Geophys., Geosyst., 12:Q0AM02. doi:10.1029/ 2011GC003804

Koppers, A.A.P., Phipps Morgan, J., Morgan, J.W., and Staudigel, H., 2001. Testing the fixed hotspot hypothesis using ${ }^{40} \mathrm{Ar} /{ }^{39} \mathrm{Ar}$ age progressions along seamount trails. Earth Planet. Sci. Lett., 185(3-4):237-252. doi:10.1016/ S0012-821X(00)00387-3

Koppers, A.A.P., Staudigel, H., Pringle, M.S., and Wijbrans, J.R., 2003. Short-lived and discontinuous intraplate vol- 
canism in the South Pacific: hot spots or extensional volcanism? Geochem., Geophys., Geosyst., 4(10):10891137. doi:10.1029/2003GC000533

Koppers, A.A.P., Staudigel, H., and Wijbrans, J.R., 2000. Dating crystalline groundmass separates of altered Cretaceous seamount basalts by the ${ }^{40} \mathrm{Ar} /{ }^{39} \mathrm{Ar}$ incremental heating technique. Chem. Geol., 166(1-2):139-158. doi:10.1016/S0009-2541(99)00188-6

Koppers, A.A.P., Yamazaki, T., and Geldmacher, J., 2010. Louisville Seamount Trail: implications for geodynamic mantle flow models and the geochemical evolution of primary hotspots. IODP Sci. Prosp., 330. doi:10.2204/ iodp.sp.330.2010

Le Bas, M.J., Le Maitre, R.W., Streckeisen, A., Zanettin, B., and the IUGS Subcommission on the Systematics of Igneous Rocks, 1986. A chemical classification of volcanic rocks based on the total alkali-silica diagram. J. Petrol., 27(3):745-750. http://petrology.oxfordjournals.org/content/27/3/745.abstract

Lindle, M.E., Colwell, L.E., Koppers, A.A., and Duncan, R.A., 2008. Evidence for differential Hawaiian and Louisville plume motions based on ${ }^{40} \mathrm{Ar} /{ }^{39} \mathrm{Ar}$ geochronology. Eos, Trans. Am. Geophys. Union, 89(53):0S41E-1263. (Abstract) http://www.agu.org/meetings/fm08/ waisfm08.html

Lonsdale, P., 1988. Geography and history of the Louisville hotspot chain in the Southwest Pacific. J. Geophys. Res., [Solid Earth], 93(B4):3078-3104. doi:10.1029/ JB093iB04p03078

Lowman, J.P., King, S.D., and Gable, C.W., 2004. Steady plumes in viscously stratified, vigorously convecting, three-dimensional numerical mantle convection models with mobile plates. Geochem., Geophys., Geosyst., 5(1):Q01L01. doi:10.1029/2003GC000583

Lyons, S.N., Sandwell, D.T., and Smith, W.H.F., 2000. Three-dimensional estimation of elastic thickness under the Louisville Ridge. J. Geophys. Res., [Solid Earth], 105(B6):13239-13252. doi:10.1029/2000JB900065

Macdonald, G.A., and Katsura, T., 1964. Chemical composition of Hawaiian lavas. J. Petrol., 5(1):82-133. http:// petrology.oxfordjournals.org/content/5/1/ 82.abstract

Mahoney, J.J., Frei, R., Tejada, M.L.G., Mo, X.X., Leat, P.T., and Nägler, T.F., 1998. Tracing the Indian Ocean Mantle domain through time: isotopic results from old west Indian, east Tethyan and South Pacific seafloor. J. Petrol., 39(7):1285-1306. http://petrology.oxfordjournals.org/cgi/content/abstract/39/7/1285

Mahoney, J.J., and Spencer, K.J., 1991. Isotopic evidence for the origin of the Manihiki and Ontong Java oceanic plateaus. Earth Planet. Sci. Lett., 104(2-4):196-210. doi:10.1016/0012-821X(91)90204-U

Mahoney, J.J., Storey, M., Duncan, R.A., Spencer, K.J., and Pringle, M.S., 1993. Geochemistry and age of the Ontong Java Plateau. In Pringle, M.S., Sager, W.W., Sliter, W.V., and Stein, S. (Eds.), The Mesozoic Pacific: Geology, Tectonics, and Volcanism. Geophys. Monogr., 77:233-262.

Mason, O.U., Nakagawa, T., Rosner, M., Van Nostrand, J.D., Zhou, J., Maruyama, A., Fisk, M.R., and Giovan- noni, S.J., 2010. First investigation of the microbiology of the deepest layer of ocean crust. PLoS One, 5(11):e15399. doi:10.1371/journal.pone.0015399

Mayer, H., and Tarduno, J.A., 1993. Paleomagnetic investigation of the igneous sequence, Site 807, Ontong Java Plateau, and a discussion of Pacific true polar wander. In Berger, W.H., Kroenke, L.W., Mayer, L.A., et al., Proc. ODP, Sci. Results, 130: College Station, TX (Ocean Drilling Program), 51-59. doi:10.2973/ odp.proc.sr.130.034.1993

McElhinny, M.W., and McFadden, P.L., 1997. Palaeosecular variation over the past $5 \mathrm{Myr}$ based on a new generalized database. Geophys. J. Int., 131(2):240-252. doi:10.1111/j.1365-246X.1997.tb01219.x

McKenzie, D., and Bickle, M.J., 1988. The volume and composition of melt generated by extension of the lithosphere. J. Petrol., 29(3):625-679.

Meibom, A., Anderson, D.L., Sleep, N.H., Frei, R., Chamberlain, C.P., Hren, M.T., and Wooden, J.L., 2003. Are high ${ }^{3} \mathrm{He} /{ }^{4} \mathrm{He}$ ratios in oceanic basalts an indicator of deep-mantle plume components? Earth Planet. Sci. Lett., 208(3-4):197-204. doi:10.1016/S0012821X(03)00038-4

Morgan, W.J., 1971. Convection plumes in the lower mantle. Nature (London, U. K.), 230(5288):42-43. doi:10.1038/230042a0

Mortimer, N., Hoernle, K., Hauff, F., Palin, J.M., Dunlap, W.J., Werner, R., and Faure, K., 2006. New constraints on the age and evolution of the Wishbone Ridge, southwest Pacific Cretaceous microplates, and ZealandiaWest Antarctica breakup. Geology, 34(3):185-188. doi:10.1130/G22168.1

Müller, R.D., Sdrolias, M., Gaina, C., and Roest, W.R., 2008. Age, spreading rates, and spreading asymmetry of the world's ocean crust. Geochem., Geophys., Geosyst., 9(4):Q04006-Q04024. doi:10.1029/2007GC001743

Nakanishi, M., and Gee, J.S., 1995. Paleomagnetic investigations of volcanic rocks: paleolatitudes of the northwestern Pacific guyots. In Haggerty, J.A., Premoli Silva, I., Rack, F., and McNutt, M.K. (Eds.), Proc. ODP, Sci. Results, 144: College Station, TX (Ocean Drilling Program), 585-604. doi:10.2973/ odp.proc.sr.144.022.1995

Niu, Y., Regelous, M., Wendt, I.J., Batiza, R., and O'Hara, M.J., 2002. Geochemistry of near-EPR seamounts: importance of source vs. process and the origin of enriched mantle component. Earth Planet. Sci. Lett., 199(3-4):327-345. doi:10.1016/S0012821X(02)00591-5

Norris, R.D., Klaus, A., and Kroon, D., 2001. Mid-Eocene deep water, the Late Palaeocene Thermal Maximum and continental slope mass wasting during the CretaceousPalaeogene impact. In Kroon, D., Norris, R.D., and Klaus, A. (Eds.), Western North Atlantic Paleogene and Cretaceous Paleoceanography. Geol. Soc. Spec. Publ., 183(1):23-48. doi:10.1144/GSL.SP.2001.183.01.02 O'Connor, J.M., Regelous, M., Koppers, A.A.P., Wijbrans, J.R., Haase, K., Stoffers, P., Steinberger, B., and Mahoney, J.J., submitted. Past mantle and plate motion from hotspot trails and bends, 1 . A combination of age pro- 
gressive and secondary volcanism in the Louisville Seamount Chain. Earth Planet. Sci. Lett.

O’Nions, R.K., 1987. Relationships between chemical and convective layering in the Earth. J. Geol. Soc. (London, U. K.), 144(2):259-274. doi:10.1144/gsjgs.144.2.0259

Parker, R.L., 1991. A theory of ideal bodies for seamount magnetization. J. Geophys. Res., [Solid Earth], 96(B10):16101-16112. doi:10.1029/91JB01497

Parker, R.L., Shure, L., and Hildebrand, J.A., 1987. The application of inverse theory to seamount magnetism. Rev. Geophys., 25(1):17-40. doi:10.1029/ RG025i001p00017

Parkes, R.J., Cragg, B.A., Bale, S.J., Getliff, J.M., Goodman, K., Rochelle, P.A., Fry, J.C., Weightman, A.J., and Harvey, S.M., 1994. Deep bacterial biosphere in Pacific Ocean sediments. Nature (London, U. K.), 371(6496):410-413. doi:10.1038/371410a0

Peckmann, J., Bach, W., Behrens, K., and Reitner, J., 2008. Putative cryptoendolithic life in Devonian pillow basalt, Rheinisches Schiefergebirge, Germany. Geobiology, 6(2):125-135. doi:10.1111/j.14724669.2007.00131.x

Petronotis, K.E., Gordon, R.G., and Acton, G.D., 1994. A 57 Ma Pacific plate paleomagnetic pole determined from a skewness analysis of crossings of marine magnetic Anomaly 25r. Geophys. J. Int., 118(3):529-554. doi:10.1111/j.1365-246X.1994.tb03983.x

Phipps Morgan, J., and Morgan, W.J., 1999. Two-stage melting and the geochemical evolution of the mantle: a recipe for mantle plum-pudding. Earth Planet. Sci. Lett., 170(3):215-239. doi:10.1016/S0012-821X(99)00114-4

Premoli Silva, I., Nicora, A., Arnaud Vanneau, A., Budd, A.F., Camoin, G.F., and Masse, J.-P., 1995. Paleobiogeographic evolution of shallow-water organisms from the Aptian to the Eocene in the western Pacific. In Haggerty, J.A., Premoli Silva, I., Rack, F., and McNutt, M.K. (Eds.), Proc. ODP, Sci. Results, 144: College Station, TX (Ocean Drilling Program), 887-893. doi:10.2973/ odp.proc.sr.144.015.1995

Putirka, K., 2008. Excess temperatures at ocean islands: implications for mantle layering and convection. Geology, 36(4):283-286. doi:10.1130/G24615A.1

Putirka, K.D., Perfit, M., Ryerson, F.J., and Jackson, M.G., 2007. Ambient and excess mantle temperatures, olivine thermometry, and active vs. passive upwelling. Chem. Geol., 241(3-4):177-206. doi:10.1016/j.chemgeo.2007.01.014

Raymond, C.A., Stock, J.M., and Cande, S.C., 2000. Fast Paleogene motion of the Pacific hotspots from revised global plate circuit constraints. In Richards, M.A., Gordon, R.G., and van der Hilst, R.D. (Eds.), The History and Dynamics of Global Plate Motions. Geophys. Monogr., 121:359-375.

Regelous, M., Hofmann, A.W., Abouchami, W., and Galer, S.J.G., 2003. Geochemistry of lavas from the Emperor Seamounts, geochemical evolution of Hawaiian magmatism from 85 to 42 Ma. J. Petrol., 44(1):113-140. doi:10.1093/petrology/44.1.113
Richards, M.A., and Griffiths, R.W., 1989. Thermal entrainment by deflected mantle plumes. Nature (London, $U$. K.), 342(6252):900-902. doi:10.1038/342900a0

Riisager, P., Hall, S., Antretter, M., and Zhao, X., 2003. Paleomagnetic paleolatitude of Early Cretaceous Ontong Java Plateau basalts: implications for Pacific apparent and true polar wander. Earth Planet. Sci. Lett., 208(3-4):235-252. doi:10.1016/S0012821X(03)00046-3

Roussel, E.G., Bonavita, M.-A.C., Querellou, J., Cragg, B.A., Webster, G., Prieur, D., and Parkes, R.J., 2008. Extending the subseafloor biosphere. Science, 320(5879):1046. doi:10.1126/science.1154545

Rouxel, O., Ono, S., Alt, J., Rumble, D., and Ludden, J., 2008. Sulfur isotope evidence for microbial sulfate reduction in altered oceanic basalts at ODP Site 801. Earth Planet. Sci. Lett., 268(1-2):110-123. doi:10.1016/ j.eps1.2008.01.010

Saal, A.E., Hart, S.R., Shimizu, N., Hauri, E.H., and Layne, G.D., 1998. Pb isotopic variability in melt inclusions from oceanic island basalts, Polynesia. Science, 282(5393):1481-1484. doi:10.1126/science.282.5393.1481

Sager, W.W., and Pringle, M.S., 1987. Paleomagnetic constraints on the origin and evolution of the Musicians and South Hawaiian Seamounts, central Pacific Ocean. In Keating, B.H., Fryer, P., Batiza, R., and Boehlert, G.W. (Eds.), Seamounts, Islands and Atolls. Geophys. Monogr., 43:133-162.

Smith, A.D., 2003. Critical evaluation of Re-Os and Pt-Os isotopic evidence on the origin of intraplate volcanism. J. Geodyn., 36(4):469-484. doi:10.1016/S02643707(02)00108-4

Smith, W.H.F., and Sandwell, D.T., 1997. Global sea floor topography from satellite altimetry and ship depth soundings. Science, 277(5334):1956-1962. doi:10.1126/science.277.5334.1956

Sobolev, A.V., 1996. Melt inclusions in minerals as a source of principle petrological information. Petrology, 4(3):209-220.

Steinberger, B., 2000. Plumes in a convecting mantle: models and observations for individual hotspots. J. Geophys. Res., [Solid Earth], 105(B5):11127-11152. doi:10.1029/ 1999JB900398

Steinberger, B., 2002. Motion of the Easter hot spot relative to Hawaii and Louisville hot spots. Geochem., Geophys., Geosyst., 3(11):8503-8529. doi:10.1029/ 2002GC000334

Steinberger, B., and Antretter, M., 2006. Conduit diameter and buoyant rising speed of mantle plumes: implications for the motion of hot spots and shape of plume conduits. Geochem., Geophys., Geosyst., 7(11):Q11018Q11042. doi:10.1029/2006GC001409

Steinberger, B., and Calderwood, A., 2006. Models of largescale viscous flow in the Earth's mantle with constraints from mineral physics and surface observations. Geophys. J. Int., 167(3):1461-1481. doi:10.1111/j.1365246X.2006.03131.X

Steinberger, B., and O'Connell, R.J., 1998. Advection of plumes in mantle flow: implications for hotspot 
motion, mantle viscosity and plume distribution. Geophys. J. Int., 132(2):412-434. doi:10.1046/j.1365246x.1998.00447.x

Steinberger, B., and O'Connell, R.J., 2000. Effects of mantle flow on hotspot motion. In Richards, M.A., Gordon, R.G., and Van der Hist, R.D. (Eds.), The History and Dynamics of Global Plate Motions. Geophys. Monogr., 121:377-398.

Steinberger, B., Sutherland, R., and O'Connell, R.J., 2004. Prediction of Emperor-Hawaii Seamount locations from a revised model of global plate motion and mantle flow. Nature (London, U. K.), 430(6996):167-173.

doi:10.1038/nature02660

Steveling, E., Stoll, J.B., and Leven, M., 2003. Quasi-continuous depth profiles of rock magnetization from magnetic logs in the HSDP-2 borehole, Island of Hawaii. Geochem., Geophys., Geosyst., 4(4):8708-8734. doi:10.1029/2002GC000330

Stoffers, P., 2003. Cruise Report SONNE 167, Louisville SuvaWellington 12 Oct.-02 Dec. 2002: Kiel (Univ. Kiel, Inst. Geowiss.).

Sun, S.S., and Hanson, G.N., 1976. Rare earth element evidence for differentiation of McMurdo volcanics, Ross Island, Antarctica. Contrib. Mineral. Petrol., 54(2):139155. doi:10.1007/BF00372120

Tarduno, J., Bunge, H.-P., Sleep, N., and Hansen, U., 2009. The bent Hawaiian-Emperor hotspot track: inheriting the mantle wind. Science, 324(5923):50-53. doi:10.1126/science.1161256

Tarduno, J.A., and Cottrell, R.D., 1997. Paleomagnetic evidence for motion of the Hawaiian hotspot during formation of the Emperor Seamounts. Earth Planet. Sci. Lett., 153(3-4):171-180. doi:10.1016/S0012821X(97)00169-6

Tarduno, J.A., Duncan, R.A., Scholl, D.W., Cottrell, R.D., Steinberger, B., Thordarson, T., Kerr, B.C., Neal, C.R., Frey, F.A., Torii, M., and Carvallo, C., 2003. The Emperor Seamounts: southward motion of the Hawaiian hotspot plume in Earth's mantle. Science, 301(5636):1064-1069. doi:10.1126/science.1086442

Tarduno, J.A., Duncan, R.A., Scholl, D.W., et al., 2002. Proc. ODP, Init. Repts., 197: College Station, TX (Ocean Drilling Program). doi:10.2973/odp.proc.ir.197.2002

Tarduno, J.A., and Sager, W.W., 1995. Polar standstill of the mid-Cretaceous Pacific plate and its geodynamic implications. Science, 269(5226):956-959. doi:10.1126/science.269.5226.956

Tarduno, J.A., Sliter, W.V., Kroenke, L., Leckie, M., Mayer, H., Mahoney, J.J., Musgrave, R., Storey, M., and Winterer, E.L., 1991. Rapid formation of Ontong Java Plateau by Aptian mantle plume volcanism. Science, 254(5030):399-403. doi:10.1126/science.254.5030.399

Tauxe, L., 2010. Essentials of Paleomagnetism: La Jolla, California (Univ. California Press). http:// www.ucpress.edu/book.php?isbn=9780520260313

Tauxe, L., and Kent, D.V., 2004. A simplified statistical model for the geomagnetic field and the detection of shallow bias in paleomagnetic inclinations: was the ancient magnetic field dipolar? Geophys. Monogr., 145:101-115.

Tejada, M.L.G., Mahoney, J.J., Duncan, R.A., and Hawkins, M.P., 1996. Age and geochemistry of basement and alkalic rocks of Malaita and Santa Isabel, Solomon Islands, southern margin of Ontong Java Plateau. J. Petrol., 37(2):361-394. doi:10.1093/petrology/37.2.361

Thorseth, I.H., Torsvik, T., Furnes, H., and Muehlenbachs, K., 1995. Microbes play an important role in the alteration of oceanic crust. Chem. Geol., 126(2):137-146. doi:10.1016/0009-2541(95)00114-8

Torsvik, T.H., Van der Voo, R., and Redfield, T.F., 2002. Relative hotspot motions versus true polar wander. Earth Planet. Sci. Lett., 202(2):185-200. doi:10.1016/S0012821X(02)00807-5

Vanderkluysen, L., Mahoney, J.J., Koppers, A.A., and Lonsdale, P.F., 2007. Geochemical evolution of the Louisville Seamount Chain. Eos, Trans. Am. Geophys. Union, 88(52)(Suppl.):V42B-06. http://www.agu.org/meetings/fm07/waisfm07.html

Virgil, C., Hördt, A., Klein, T., Kück, J., Leven, M., and Steveling, E., 2010. High-precision orientation of threecomponent magnetic downhole logs. Sci. Drill., 9:3740. doi: 10.2204/iodp.sd.9.07.2010

Wallace, P.J., 2005. Volatiles in subduction zone magmas: concentrations and fluxes based on melt inclusion and volcanic gas data. J. Volcanol. Geotherm. Res., 140(13):217-240. doi:10.1016/j.jvolgeores.2004.07.023

Watts, A.B., Weissel, J.K., Duncan, R.A., and Larson, R.L., 1988. Origin of the Louisville Ridge and its relationship to the Eltanin Fracture Zone. J. Geophys. Res., [Solid Earth], 93(B4):3051-3077. doi:10.1029/ JB093iB04p03051

Wessel, P., and Kroenke, L.W., 1997. A geometric technique for relocating hotspots and refining absolute plate motions. Nature (London, U. K.), 387(6631):365-369. doi:10.1038/387365a0

Wessel, P., and Kroenke, L.W., 2009. Observations of geometry and ages constrain relative motion of Hawaii and Louisville plumes. Earth Planet. Sci. Lett., 284(3-4):467472. doi:10.1016/j.epsl.2009.05.012

Wilson, J.T., 1963. A possible origin of the Hawaiian Islands. Can. J. Phys., 41(6):863-870. doi:10.1139/p63094

Wilson, P.A., Jenkyns, H.C., Elderfield, H., and Larson, R.L., 1998. The paradox of drowned carbonate platforms and the origin of Cretaceous Pacific guyots. Nature (London, U. K.), 392(6679):889-894. doi:10.1038/31865

Worthington, T.J., Hekinian, R., Stoffers, P., Kuhn, T., and Hauff, F., 2006. Osbourn Trough: structure, geochemistry and implications of a mid-Cretaceous paleospreading ridge in the South Pacific. Earth Planet. Sci. Lett., 245(3-4):685-701. doi:10.1016/j.epsl.2006.03.018

Publication: 11 February 2012 MS 330-101 
Figure F1. A. Louisville Seamount Trail with its narrow $75 \mathrm{~km}$ wide chain of guyots and seamounts. The five seamounts drilled during Expedition 330 are indicated by pink circles. B. Available dredge samples from Watts et al. (1988), R/V Sonne cruise SO167, and AMAT02RR site survey.

\section{A}

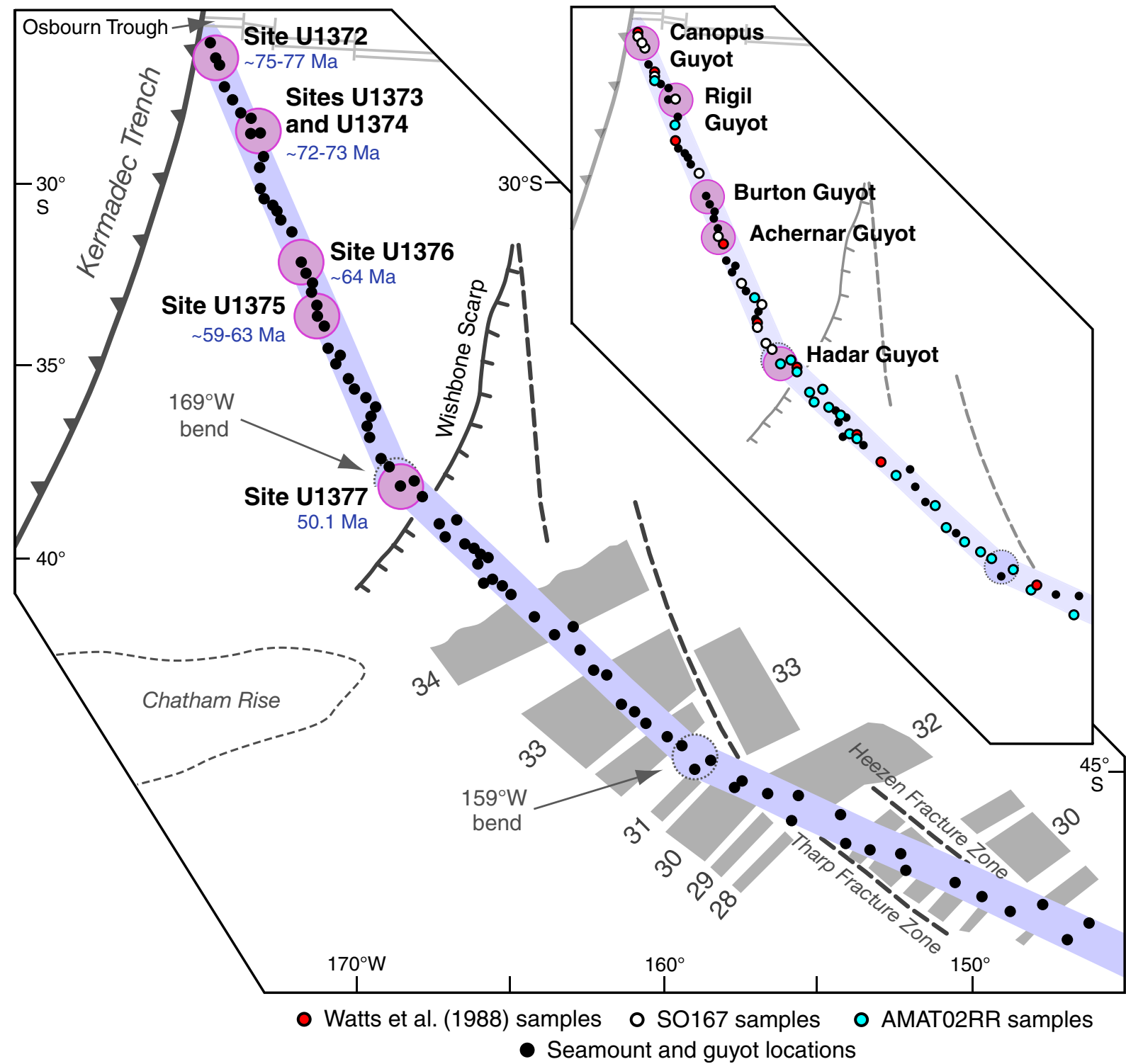


Figure F2. A. Results of mantle flow modeling for the Louisville hotspot, showing a maximum paleolatitude shift of only $\sim 2.5^{\circ}$ at $60 \mathrm{Ma}$ (after Steinberger et al., 2004). B. Revised model constrained by plume initiation age of $90 \mathrm{Ma}$ and new ${ }^{40} \mathrm{Ar} /{ }^{39} \mathrm{Ar}$ ages (Koppers et al., 2004). C. Variations in the predicted motion of the Louisville hotspot based on a range of model assumptions, such as location of present-day hotspot, mantle plume initiation ages, and mantle viscosity models (Steinberger and Antretter, 2006).

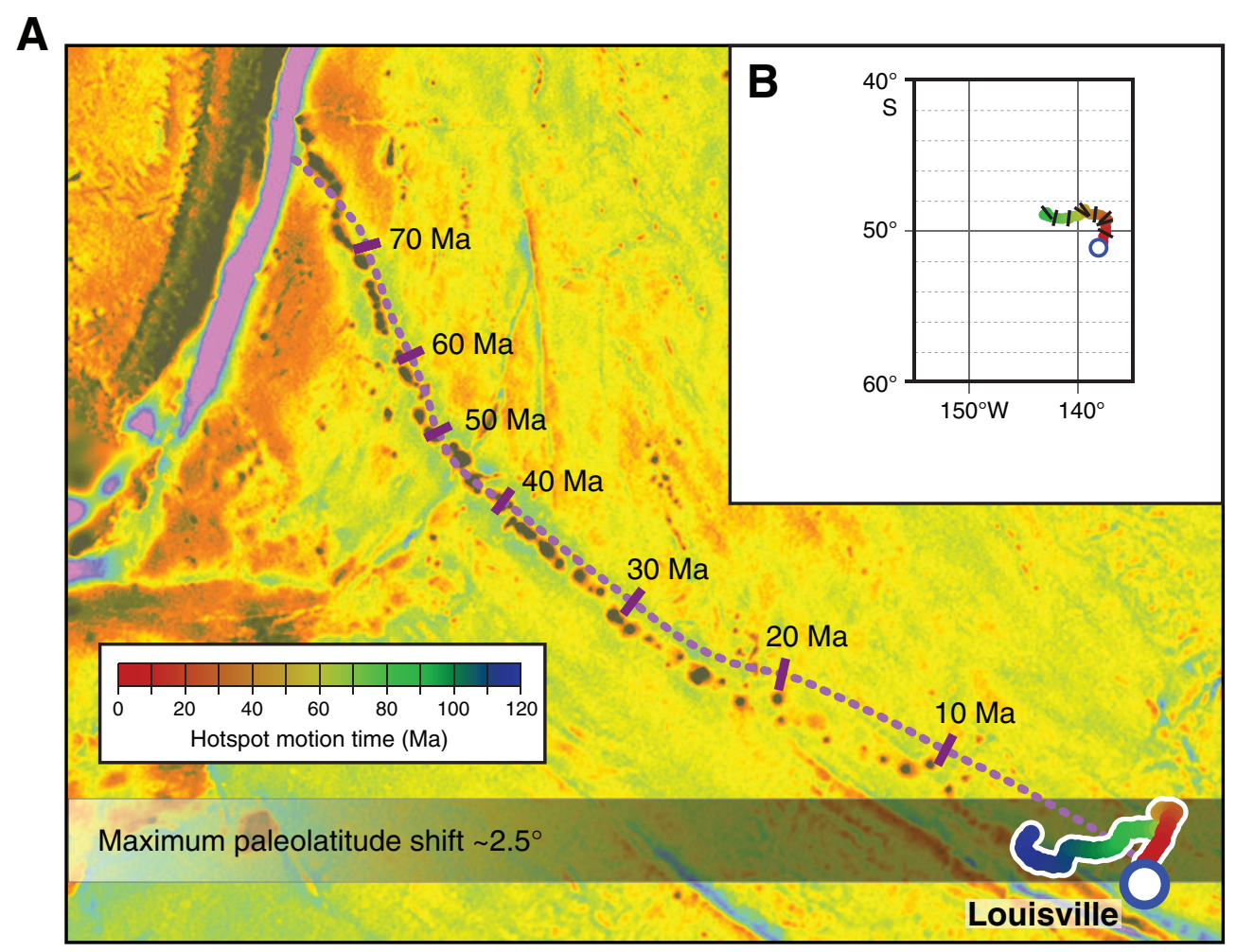

C

\begin{tabular}{|c|c|c|c|c|c|}
\hline \multicolumn{2}{|c|}{$\begin{array}{l}\text { Hotspot location } \\
138.1^{\circ} \mathrm{W}, 50.9^{\circ} \mathrm{S}\end{array}$} & \multicolumn{2}{|c|}{$\begin{array}{l}\text { Hotspot location } \\
141.2^{\circ} \mathrm{W}, 53.5^{\circ} \mathrm{S}\end{array}$} & \multicolumn{2}{|c|}{$\begin{array}{l}\text { Hotspot location } \\
138.1^{\circ} \mathrm{W}, 50.9^{\circ} \mathrm{S}\end{array}$} \\
\hline \multicolumn{4}{|c|}{$\begin{array}{c}\text { Hotspot age } \\
121 \mathrm{Ma}\end{array}$} & \multicolumn{2}{|c|}{$\begin{array}{c}\text { Hotspot age } \\
90 \mathrm{Ma}\end{array}$} \\
\hline $\begin{array}{l}\text { Viscosity } \\
\text { Model } 1\end{array}$ & $\begin{array}{l}\text { Viscosity } \\
\text { Model } 2\end{array}$ & $\begin{array}{l}\text { Viscosity } \\
\text { Model } 1\end{array}$ & $\begin{array}{l}\text { Viscosity } \\
\text { Model } 2\end{array}$ & $\begin{array}{l}\text { Viscosity } \\
\text { Model } 1\end{array}$ & $\begin{array}{l}\text { Viscosity } \\
\text { Model } 2\end{array}$ \\
\hline
\end{tabular}

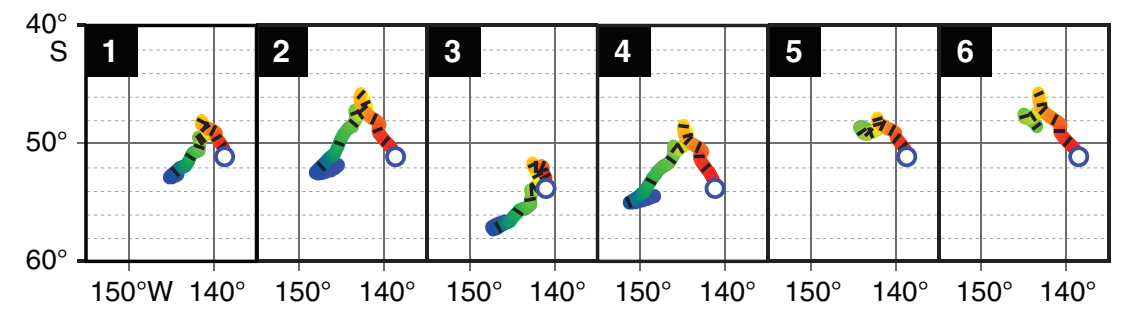


Figure F3. Predicted location of Louisville hotspot track based on Indo-Atlantic data transferred to the Pacific plate via global plate circuits. Red = standard plate circuit (i.e., Cande et al., 1995) with transfer from the Atlantic Basin through East and West Antarctica (EANT-WANT), based on present-day hotspot location at $50.9^{\circ} \mathrm{S}$, $138.0^{\circ} \mathrm{W}$ (Lonsdale, 1988); o = older end of Chron, $\mathrm{y}=$ younger end of Chron. Blue = alternate plate circuit (Steinberger et al., 2004) with transfer through the Lord Howe Rise (LHR). Gray shaded areas = older seamounts in the Louisville Seamount Trail. Green circles = presumed locations of seamounts having ages corresponding to those drilled in the Hawaiian-Emperor Seamount Trail. Orange $=$ alternate location of present-day hotspot location at $53.5^{\circ} \mathrm{S}, 141.12^{\circ} \mathrm{W}$ (Epp, 1978; Wessel and Kroenke, 1997; no reconstruction shown for this alternate hotspot location). Reproduced from unpublished work by J. Tarduno, R. Cottrell, and P. Doubrovine (Rochester University). AUS = Australian plate.

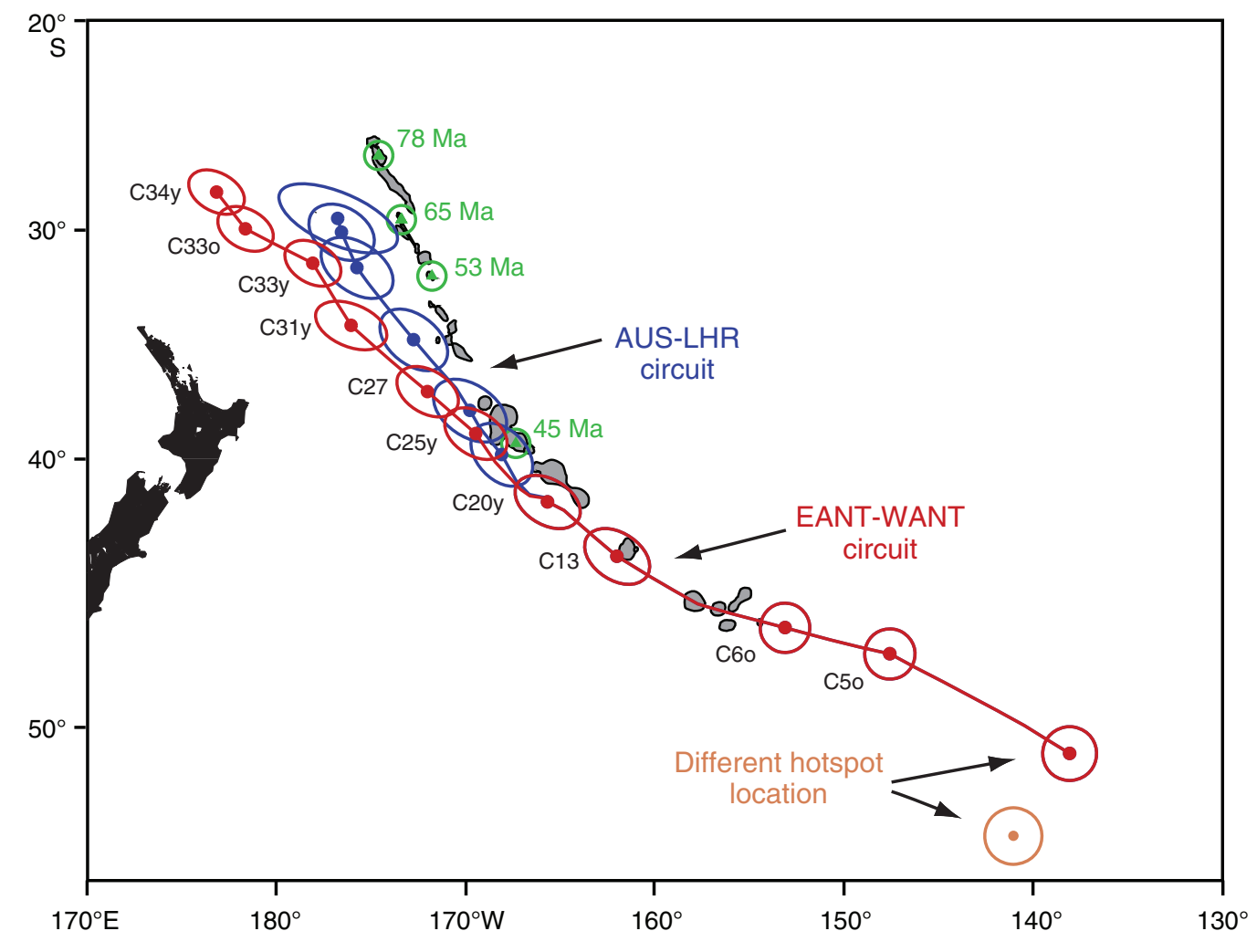


Figure F4. A. Plots of preliminary incremental heating ${ }^{40} \mathrm{Ar} /{ }^{39} \mathrm{Ar}$ ages of A.A.P. Koppers (AMAT02RR; Koppers et al., 2011) and J. O'Connor (SO167; O'Connor et al., submitted), with age data from Koppers et al. (2004) and total fusion ages after Watts et al. (1988). B. Example incremental heating diagrams on samples from the AMAT02RR site survey cruise.

A

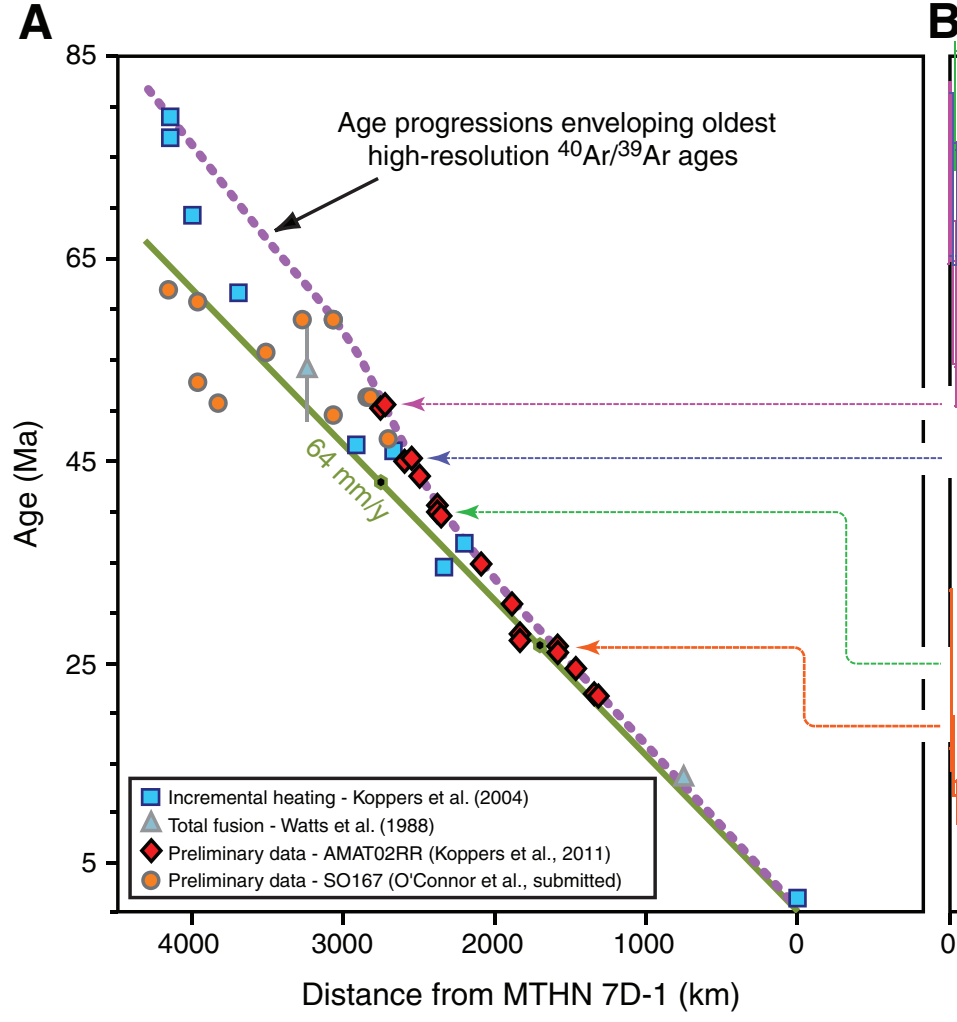

B

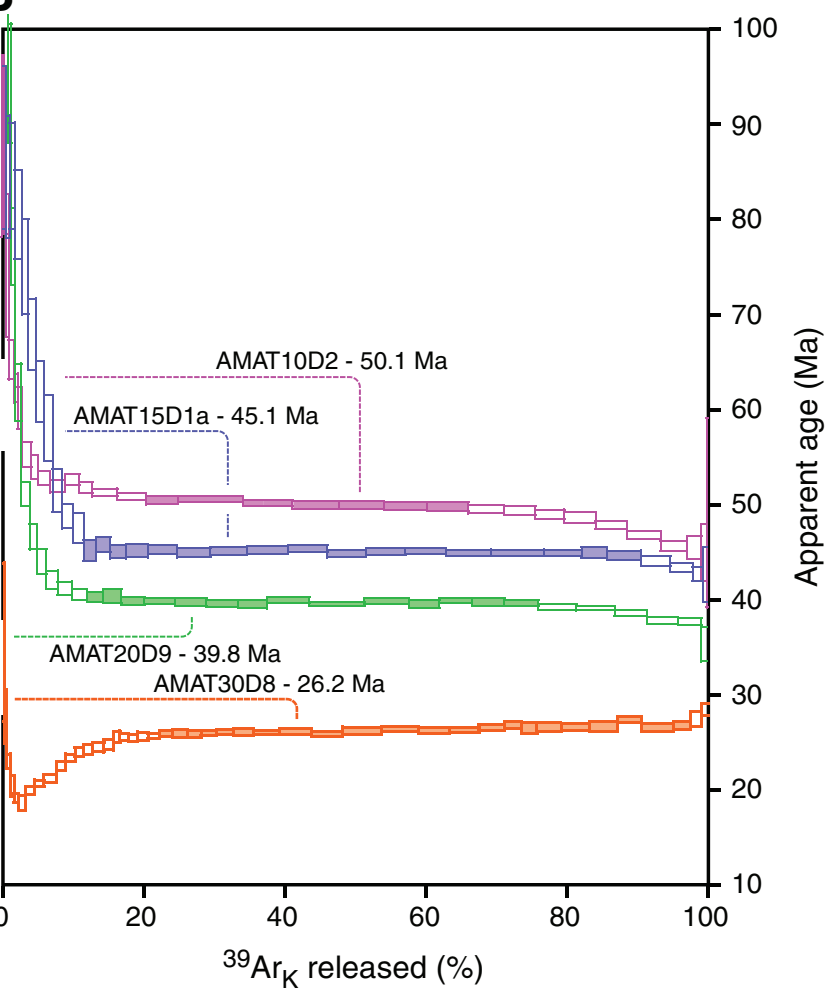


Figure F5. Results from seismic refraction experiment across Louisville Seamount Trail. A. Velocity model obtained from tomographic inversion of traveltimes from crustal and mantle phases along a single $370 \mathrm{~km}$ long seismic refraction line conducted orthogonal to the overall northwest trend of the Louisville Seamount Trail and crossing the summit of the $27.6^{\circ} \mathrm{S}$ guyot $\left(\sim 1.1^{\circ}\right.$ south of prospectus Site LOUI-1C) during the German SO195 cruise (Grevemeyer and Flüh, 2008). B. Geologic interpretation revealing some internal seamount structures based on seismic velocity values: $1.5-4.0 \mathrm{~km} / \mathrm{s}$ for volcaniclastic and mass wasting deposits, $7.2-7.6 \mathrm{~km} / \mathrm{s}$ for intracrustal magma intrusion, $8.0 \mathrm{~km} / \mathrm{s}$ for upper mantle, $5.0-6.4 \mathrm{~km} / \mathrm{s}$ for extrusive volcano, and $6.4-7.0 \mathrm{~km} / \mathrm{s}$ for intrusive core. Assumed upper and lower crustal velocity ranges are 4.0-6.4 and $6.4-7.2 \mathrm{~km} / \mathrm{s}$, respectively. Infill material is likely to be the volcaniclastic sequence directly underlying the pelagic cap that is thickening toward the edge of the guyot shelves, as seen on the AMAT02RR multichannel seismic reflection data. Both cross sections after Contreras-Reyes et al. (2010).

A

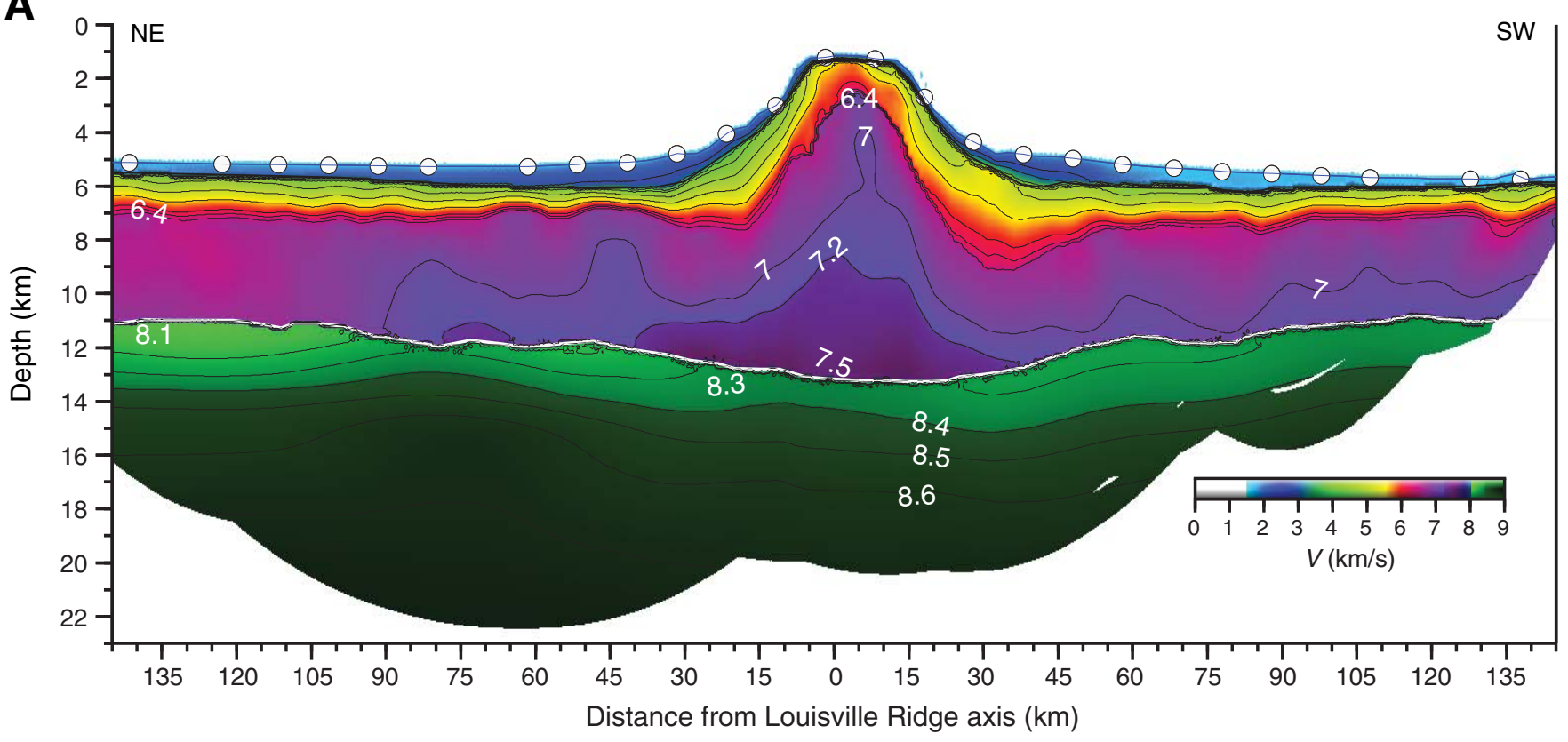

B

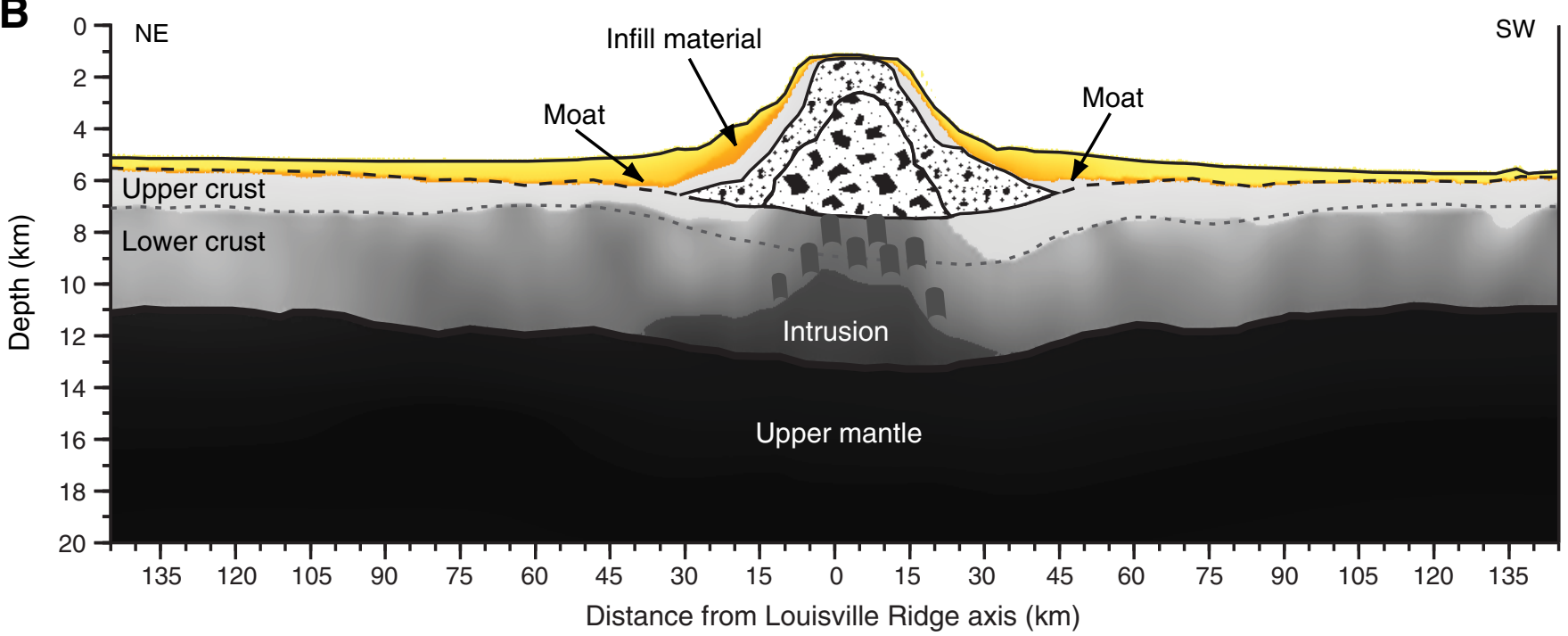


Figure F6. A. Alkalinity diagram of Le Bas et al. (1986), with division of alkaline vs. subalkaline (tholeiitic) series from MacDonald and Katsura (1964), showing an absence of tholeiitic rocks in the current sample suites for the Louisville Seamount Trail. B. Correlation plot for $\mathrm{Nd}$ and $\mathrm{Pb}$ isotopes, showing the remarkably homogeneous composition for Louisville samples spanning $80 \mathrm{~m} . \mathrm{y}$. Note the marked difference from the two Ontong Java Plateau (OJP) basalt groups. Similarly homogeneous signatures are evident in the HFSE Zr/Y and Nb/Y trace element ratios (not shown). These diagrams include published data from Hawkins et al. (1987) and Cheng et al. (1987), as well as unpublished data from the AMAT02RR site survey cruise (L. Vanderkluysen). EM= enriched mantle, HIMU = "high $\mu$ " (high, time-integrated ${ }^{238} \mathrm{U} /{ }^{204} \mathrm{~Pb}$ ratios).
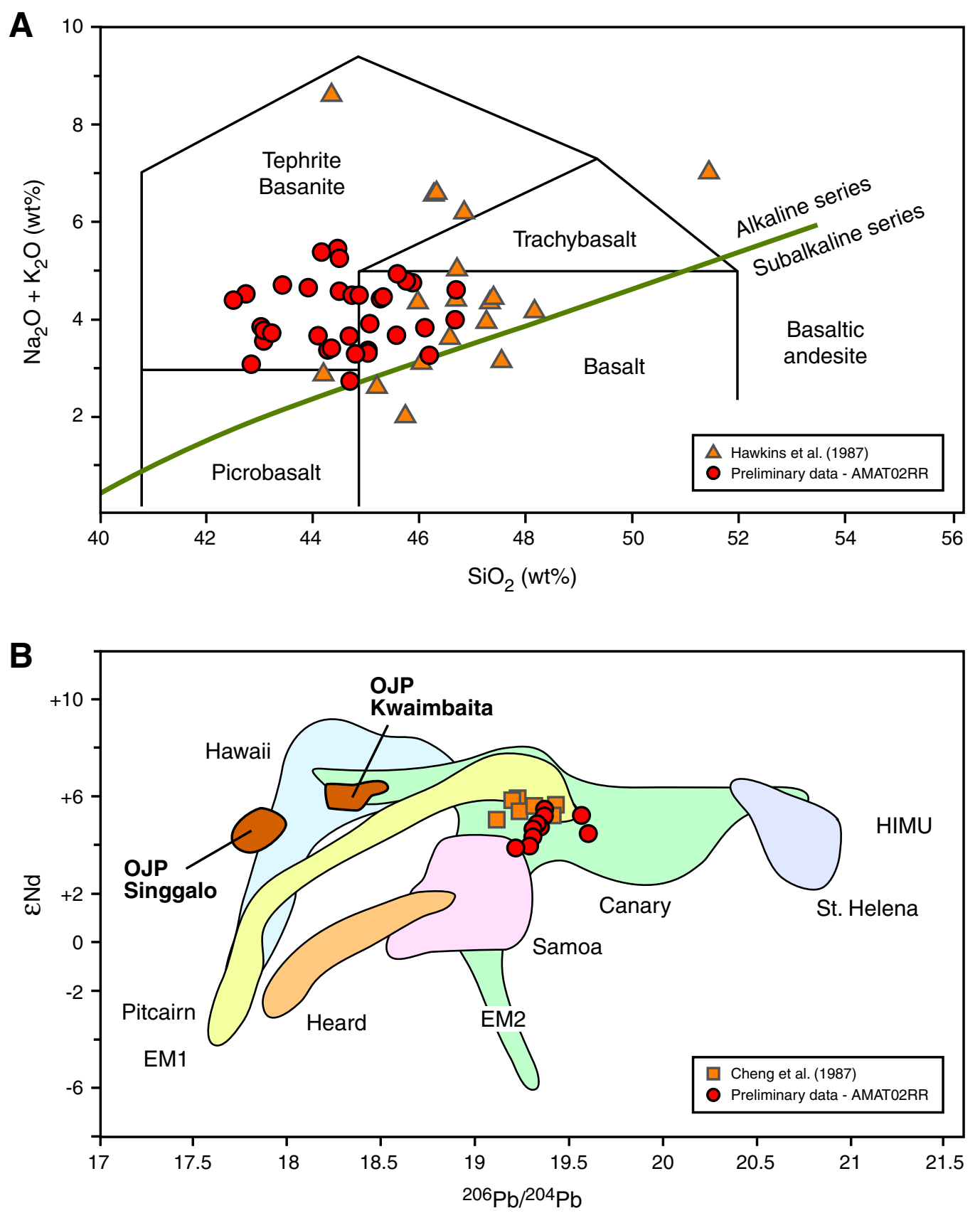
Figure F7. Magnetic anomaly pattern and paleopole positions for the $168.6^{\circ} \mathrm{W}$ seamount. A. Magnetic anomaly pattern (red/blue scale) and topography (black lines $=500 \mathrm{~m}$ contours). Survey track shown as dashed green line. B. Paleopole positions (and 95\% confidence bounds in red) derived from the uniform magnetization component for misfits of 60-20 nT with a seminorm inversion compared to Pacific poles from Sager and Pringle (1987) (black). LSQ = least-squares solution. Note that the anomaly pattern is of quite low amplitude and relatively complex, possibly suggesting the presence of dual polarities (reversed polarity dominant).

A

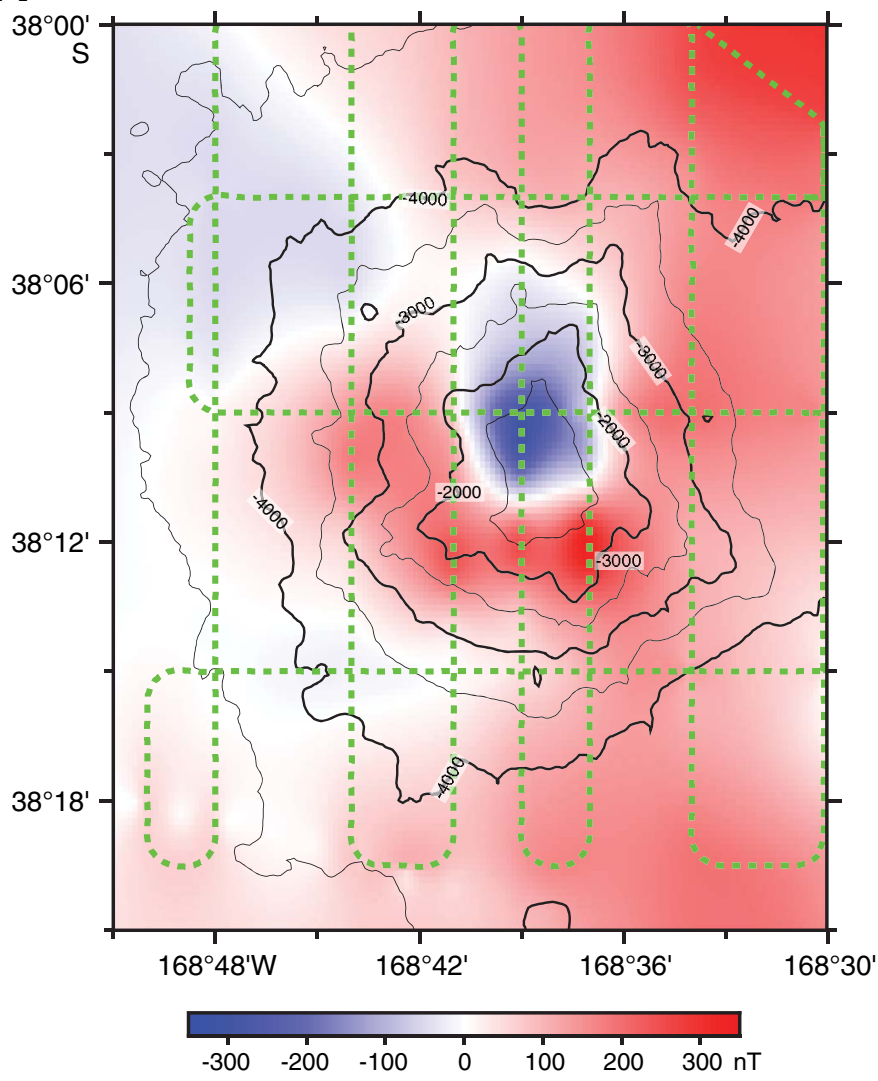

B

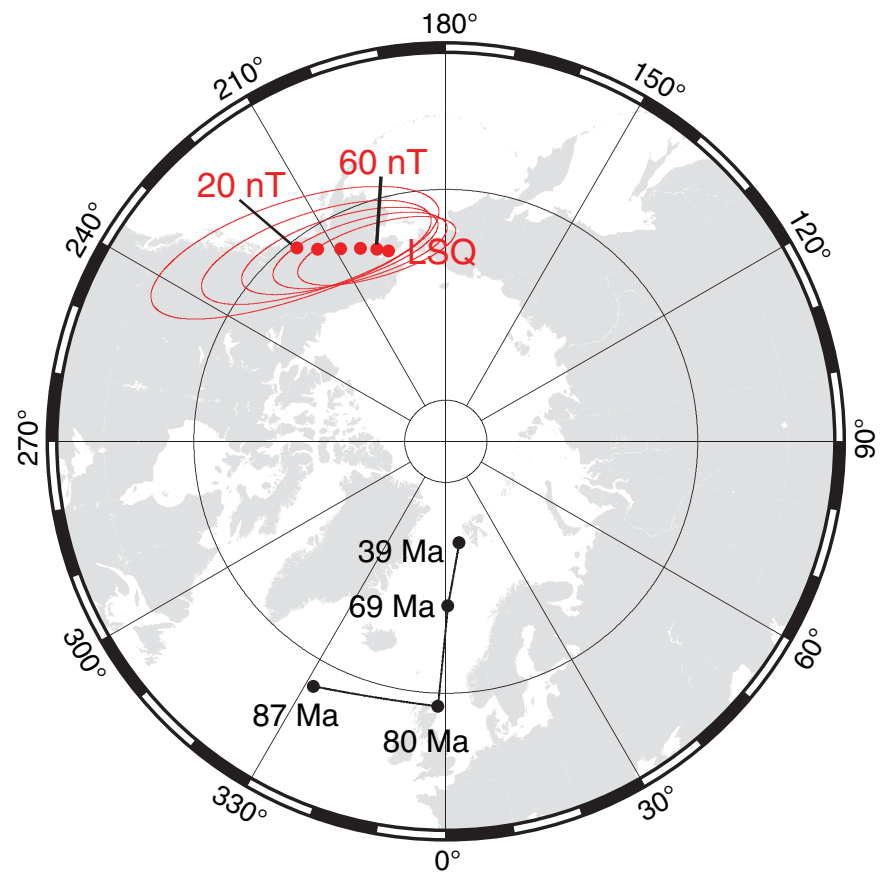


Figure F8. Magnetic anomaly pattern and paleopole positions for the $35.8^{\circ} \mathrm{S}$ seamount. A. Relatively simple magnetic anomaly pattern (red/blue scale) and topography (black lines $=500 \mathrm{~m}$ contours). Survey track shown as dashed green line. B. Paleopole positions (and 95\% confidence bounds in red) derived from the uniform magnetization component for misfits of 60-20 nT compared to Pacific poles from Sager and Pringle (1987) (black). LSQ = least-squares solution.

A

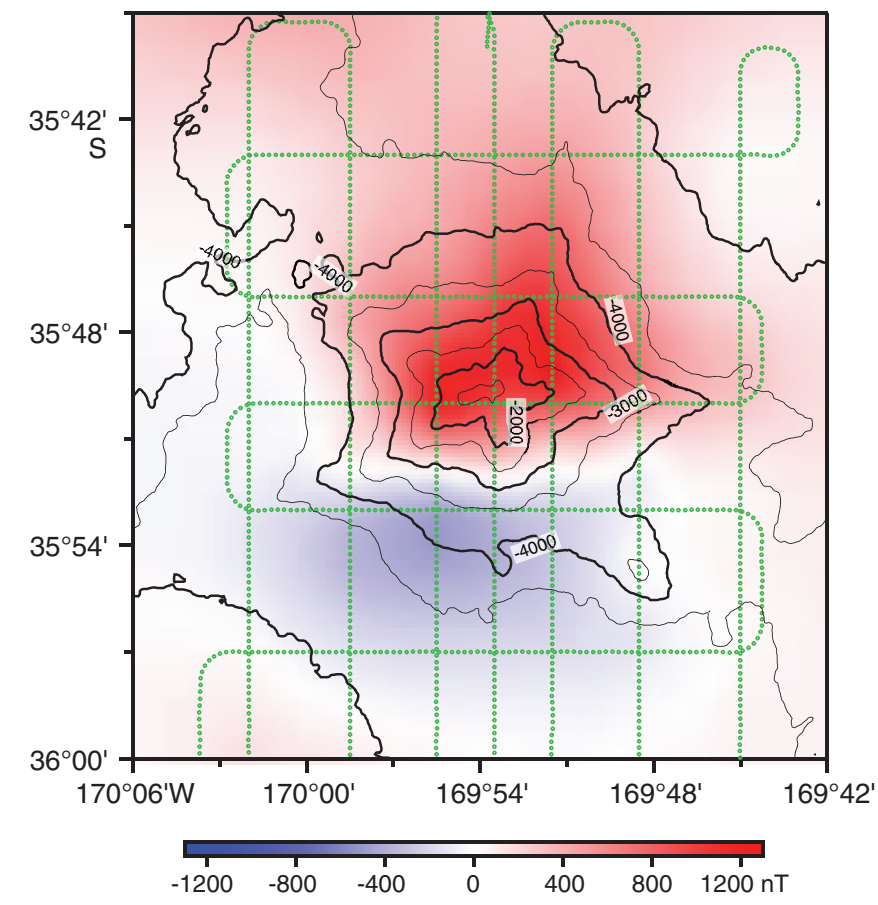

B

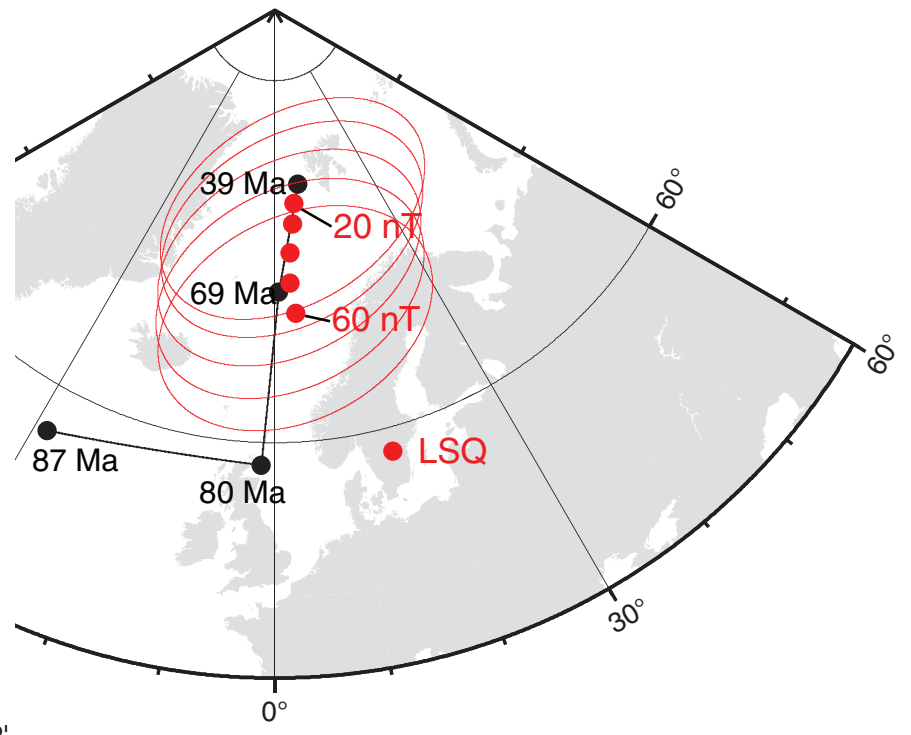


Figure F9. Plots of paleosecular variation and paleolatitude uncertainties. A. Mean and 95\% paleolatitude uncertainties at $50^{\circ} \mathrm{S}$ as a function of the number of temporally independent flow groups based on two recent paleosecular variation models. B. Number of independent flow groups from selected DSDP/ODP sites. Hawaiian-Emperor data from DSDP Leg 55 (Kono, 1980) and ODP Legs 145 (Tarduno and Cottrell, 1997) and 197 (Tarduno et al., 2003). Solid squares for Suiko and Detroit Seamounts indicate total number of flow units, including volcaniclastic units. Kerguelen-Ninetyeast Ridge data from ODP Legs 120 (Inokuchi and Heider, 1992), 121 (Klootwijk et al., 1991), and 183 (Antretter et al., 2002). Pacific atoll/guyot data from ODP Legs 143 (Tarduno and Sager, 1995) and 144 (Nakanishi and Gee, 1995). Ontong Java Plateau data from ODP Legs 130 (Mayer and Tarduno, 1993) and 192 (Riisager et al., 2003). C. Paleolatitude uncertainties vs. flow group numbers, based on same references as B.
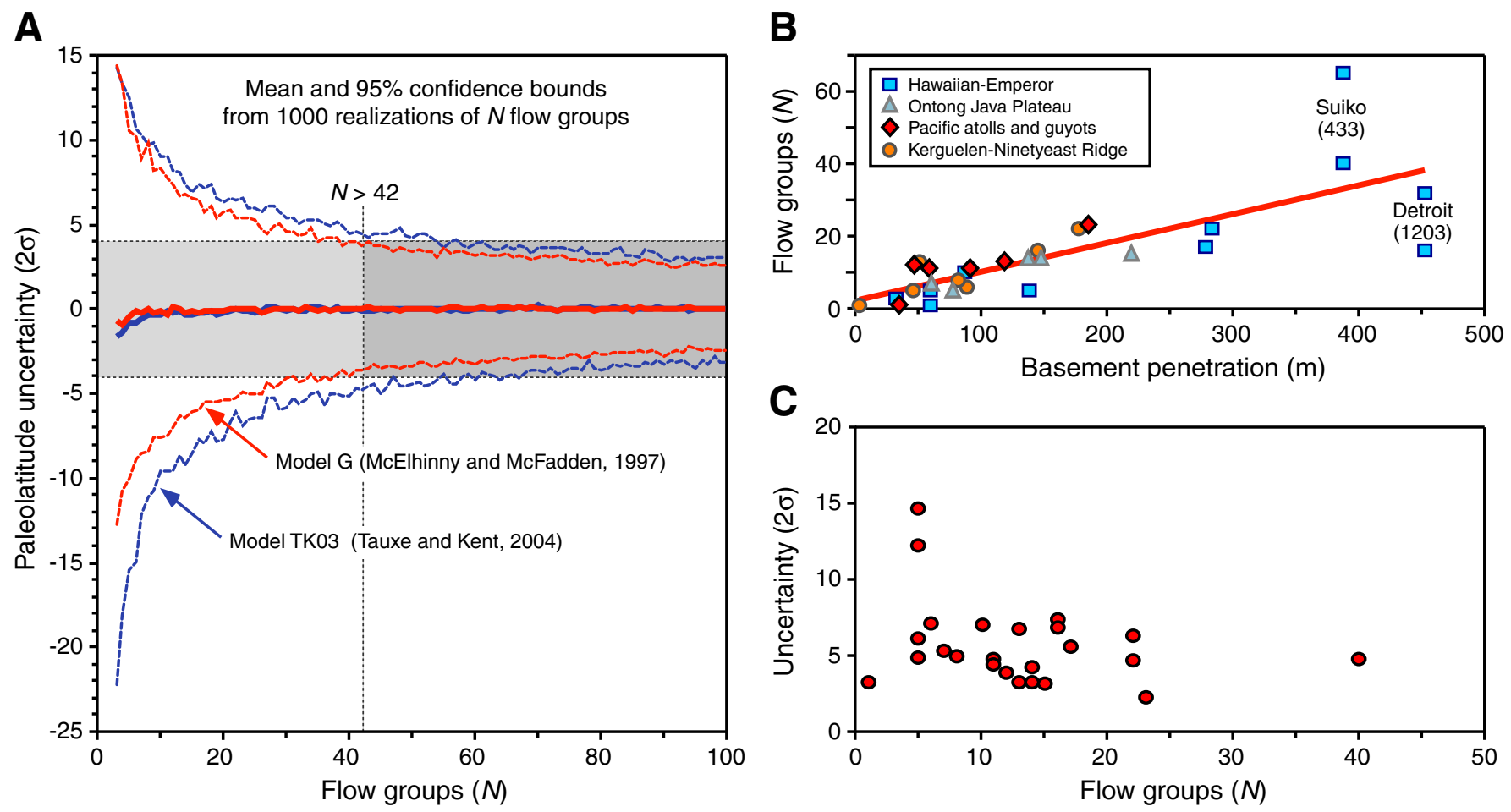
Figure F10. A. Schematic of Göttingen Borehole Magnetometer (GBM) showing inclinometer, fiber-optic gyros, and Förster-magnetometer triplet (from Virgil et al., 2010). B. Schematic drawing of GBM tool string as deployed downhole during Expedition 330, including a centralizer (to keep GBM in center of hole) and two sinker bars (made of tungsten carbide and nonmagnetic aluminum), with the nonmagnetic one positioned just above the GBM.

A

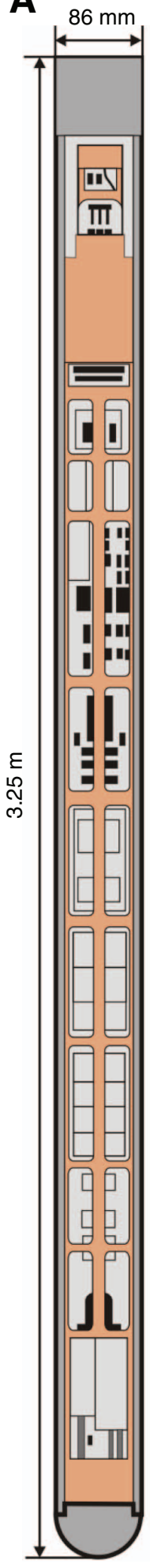

B

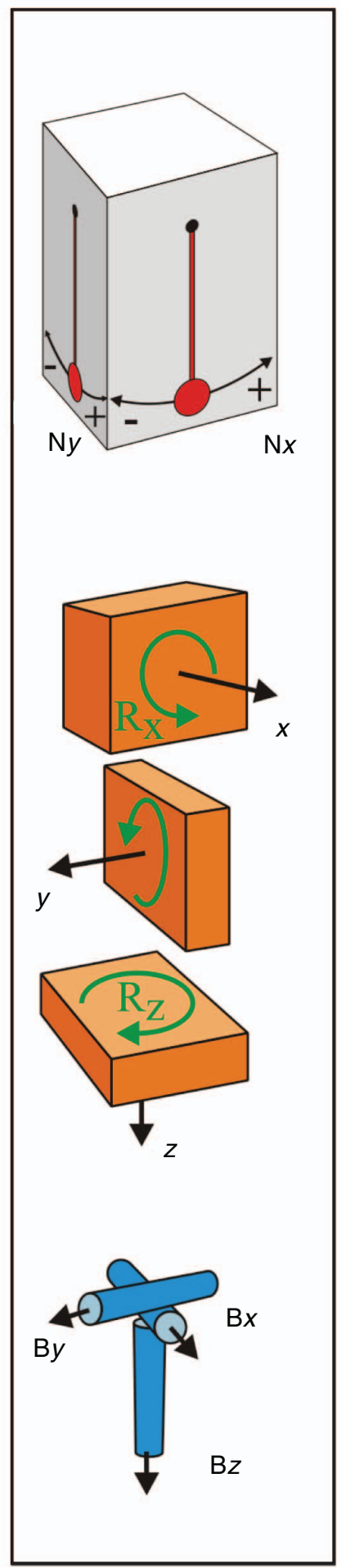

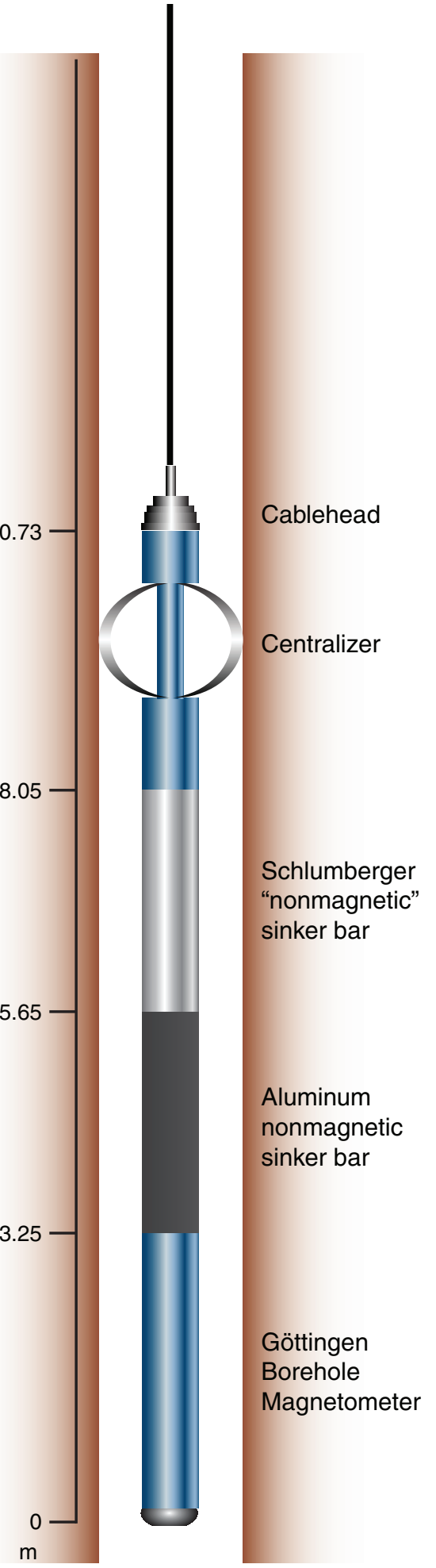


Figure F11. Detailed bathymetric map of Site U1372 (prospectus Site LOUI-1C) on Canopus Guyot, as well as Osbourn and $26.6^{\circ} \mathrm{S}$ Guyots. GMT-generated bathymetric map is based on a combination of SIMRAD EM120 multibeam data collected during the AMAT02RR site survey expedition aboard the R/V Roger Revelle and global predicted bathymetry (v8.2) from Smith and Sandwell (1997). Dredge locations from previous cruises are indicated by squares. Crossing multichannel seismic reflection lines collected during the AMAT02RR site survey are shown in blue (for details see Koppers et al., 2010). Map uses a linear projection (i.e., horizontal and vertical scales differ) based on WGS-84.

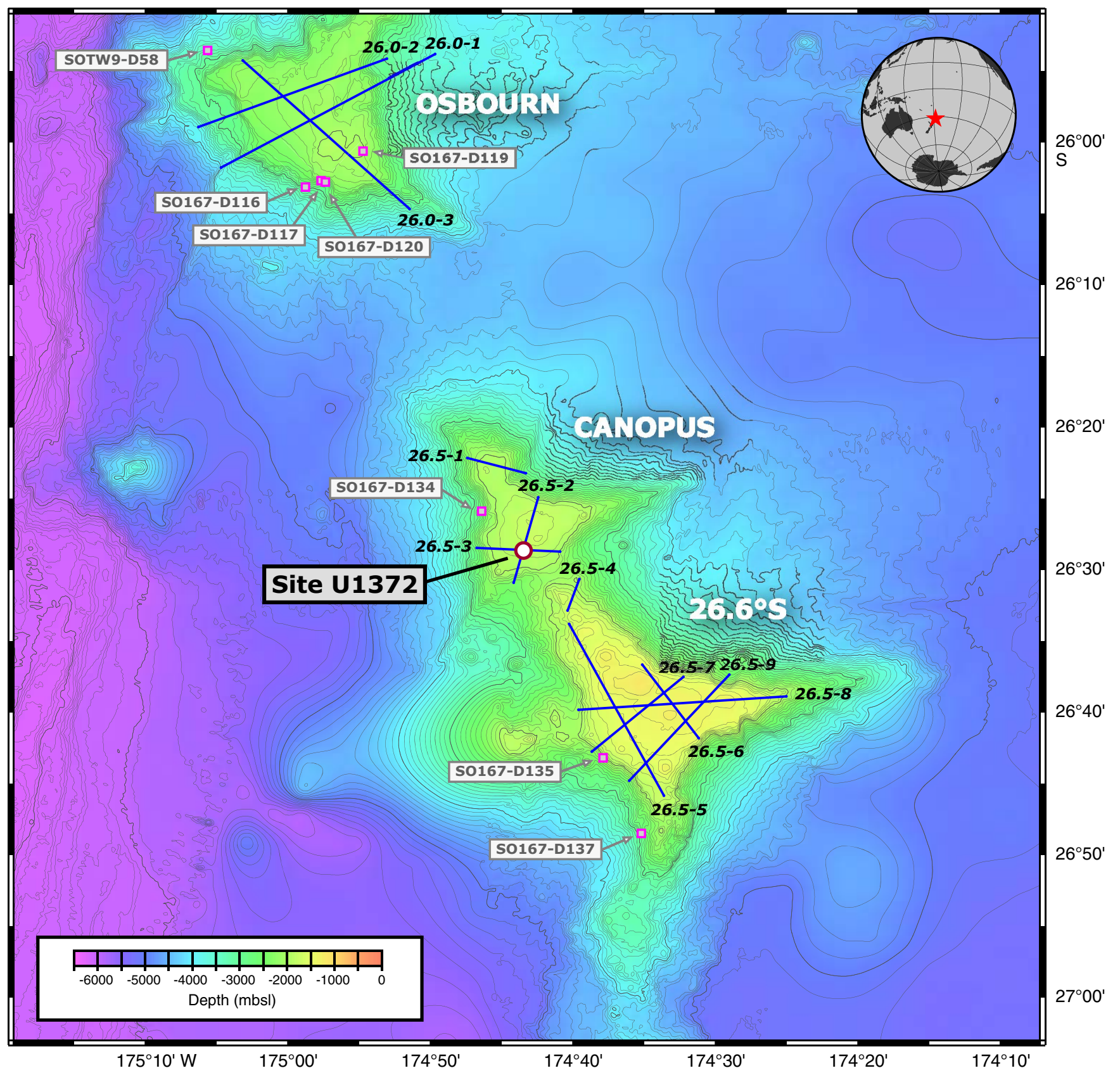


Figure F12. Stratigraphic summary, Hole U1372A. A. Sedimentary sequence. B. Lithology and volcanological features of igneous sequence.

Hole U1372A
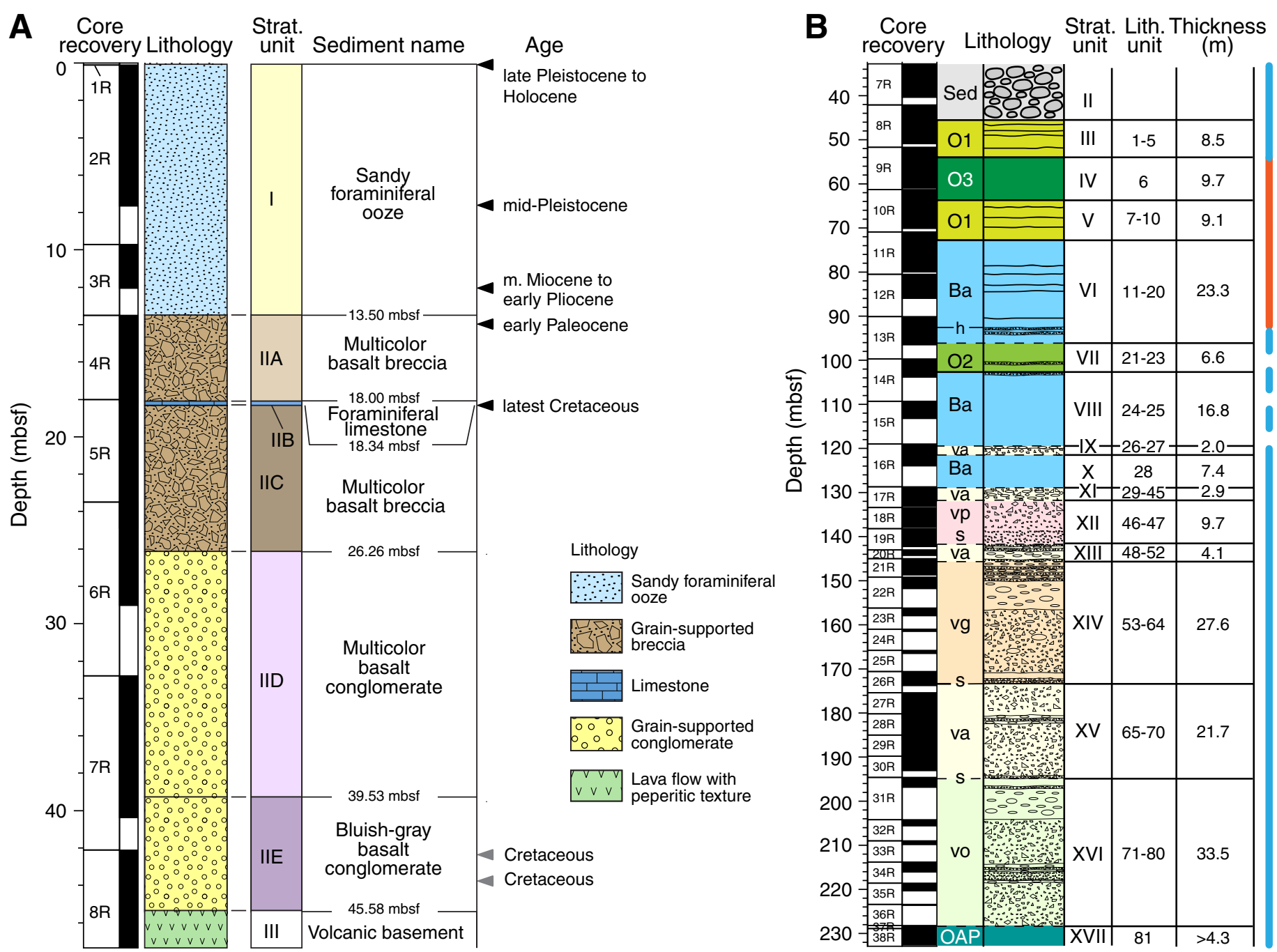
을. S Sedimentary rocks
ผ
$\bar{\sigma} \quad$ Lava flow packages
$\mathrm{O} 3$ Highly olivine-phyric
O3 basalt
O2 Moderately
01 Sparsely olivine-phyric
OAP Moderately olivine-augite-
$\mathrm{Ba}$ Aphyric basalt
Volcaniclastic rocks (based on clast types)

\begin{tabular}{|c|c} 
vp & Plagioclase-phyric basalt \\
\hline \hline $\mathrm{vg}$ & Glomerophyric basalt \\
\hline \hline $\mathrm{va}$ & Aphyric basalt \\
\hline $\mathrm{yn}$ & $\begin{array}{l}\text { Plagioclase-olivine- } \\
\text { phyric basalt }\end{array}$ \\
\hline
\end{tabular}
Volcanological features

\begin{tabular}{cl} 
& Lava flows \\
\hline S & Vitric-lithic volcanic sand \\
h & Stratigraphically highest \\
& occurrence of hyaloclastite
\end{tabular}


Figure F13. Close-up photographs of select representative lithologies and lithofacies encountered at Site U1372. A. Multicolor basalt breccia (interval 330-U1372A-4R-2, 1-14 cm). B. Lobate margin of basalt clast or small lava pod (gray) (interval 330-U1372A-28R-1, 24-34 cm).
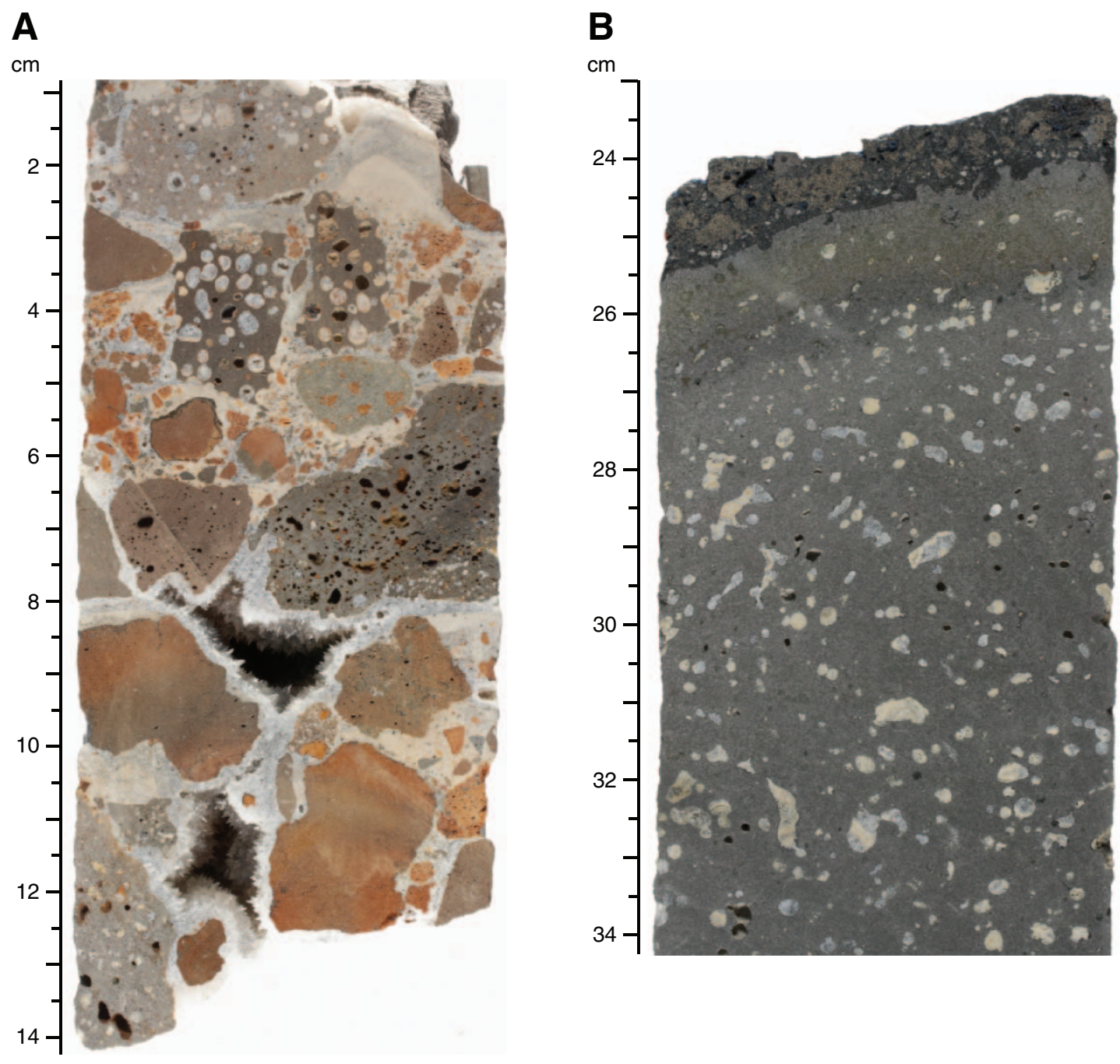
Figure F14. Thin section photomicrographs of microfossils, Site U1372. A. Annelids showing infilling of volcanic sediments and micrite and later calcite cement forming a horizontal geopetal (Sample 330-U1372A-8R1, 20-23 cm; Thin Section 20) (with crossed polars). Arrow points toward top of core. B. Planktonic foraminifers (Sample 330-U1372A-5R-4, 49-52 cm; Thin Section 53) (plane-polarized light). Most Site U1372 planktonic foraminifers observed in thin section are globular morphotypes with four or more chambers. Specimens shown here might be a group of hedbergellids. Because these specimens have not been sectioned axially, their identification awaits further onshore study.
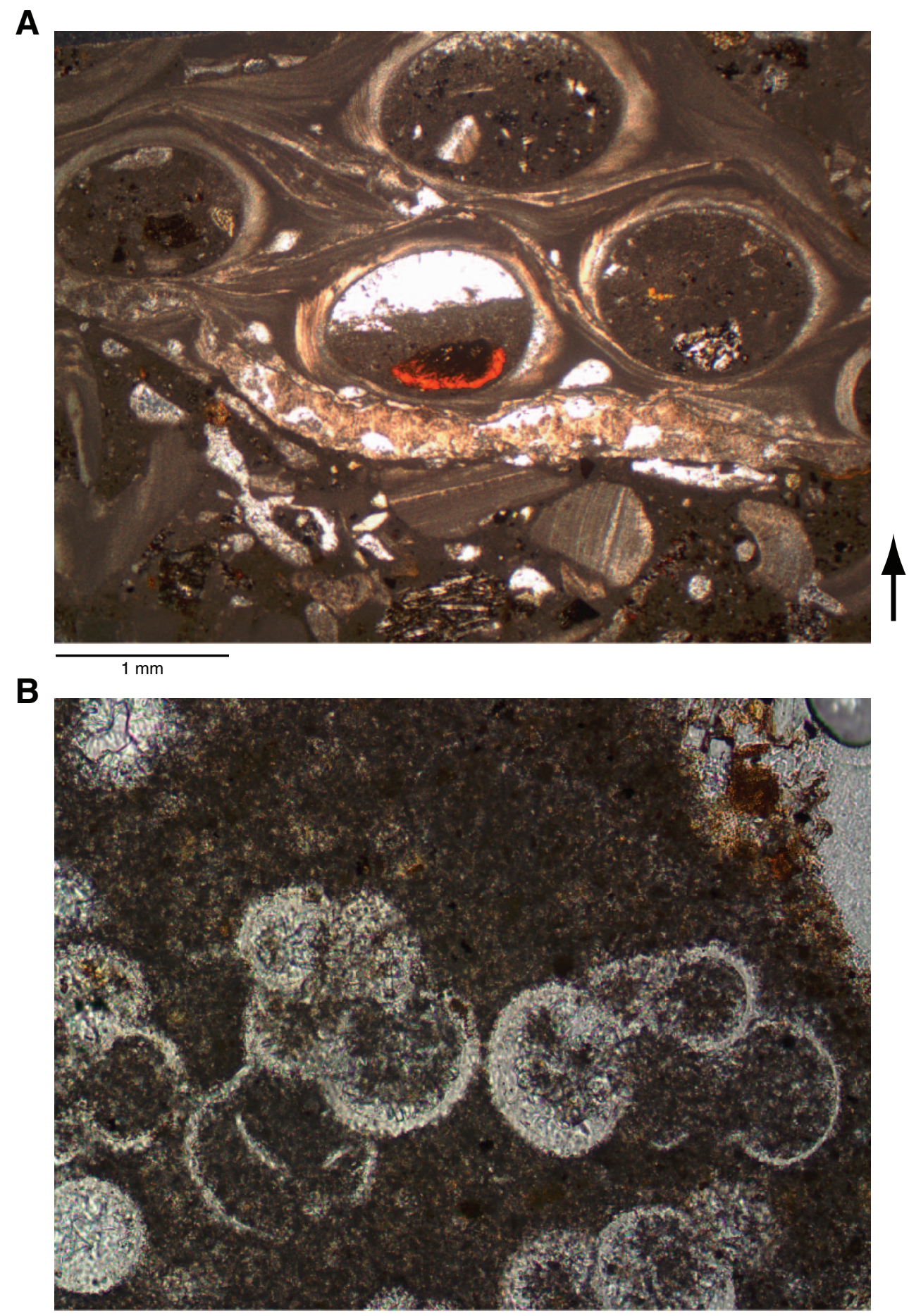

$0.1 \mathrm{~mm}$ 
Figure F15. Thin section photomicrographs of basalt, Site U1372. A. Highly olivine-phyric basalt from Unit IV (Sample 330-U1372A-9R-6, 39-41 cm; Thin Section 26) (with crossed polars). B. Olivine and plagioclase phenocrysts in glass matrix with microcrysts of plagioclase (Sample 330-U1372A-18R-3, 14-16 cm; Thin Section 51) (partly crossed polars). C. Same as B, except with crossed polars. D. Sector zoning in a titanaugite microphenocryst in an aphyric basalt clast from Unit XIV (Sample 330-U1372A-22R-1, 127-130 cm; Thin Section 60) (with crossed polars).

A

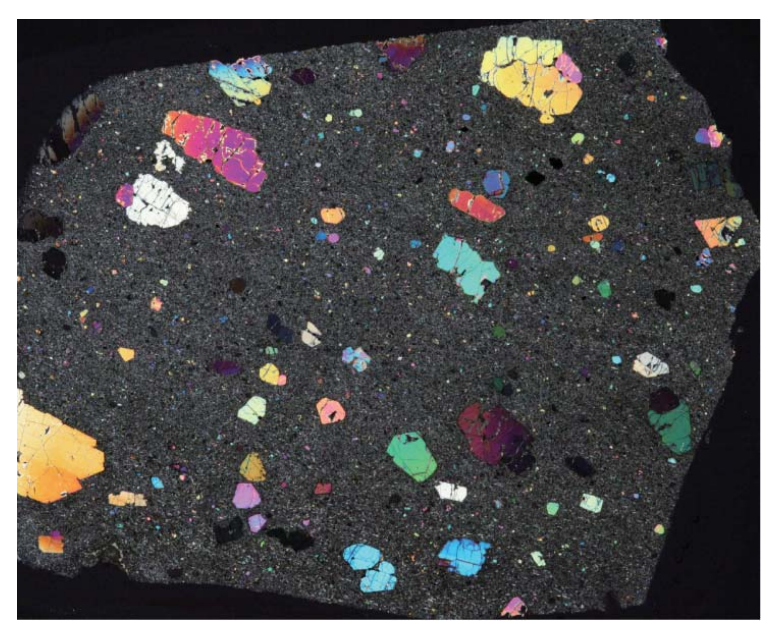

$$
5 \mathrm{~mm}
$$

C

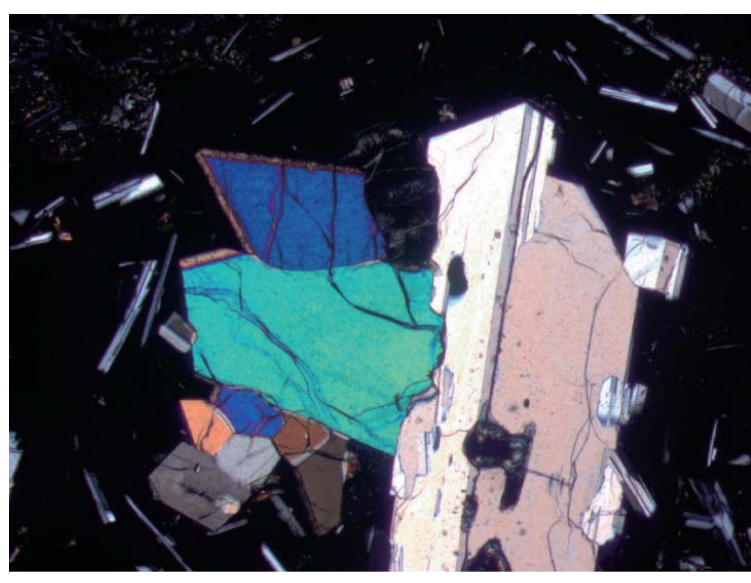

$1 \mathrm{~mm}$
B

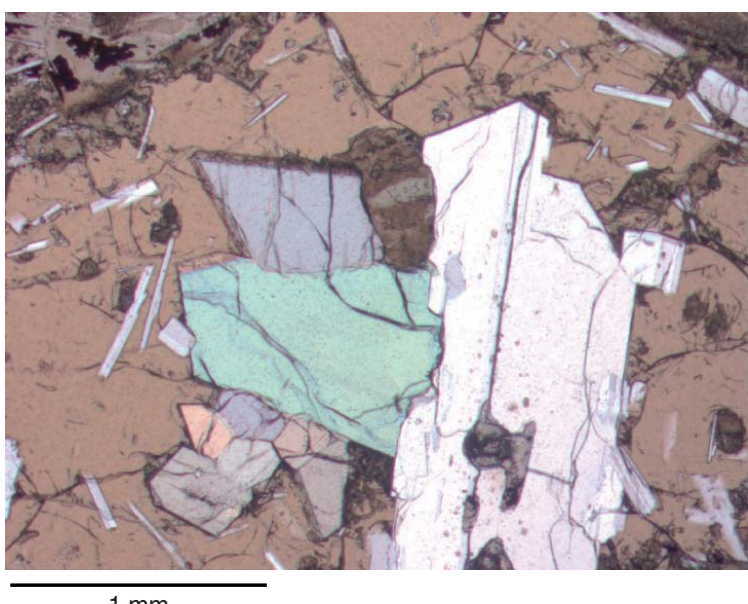

D

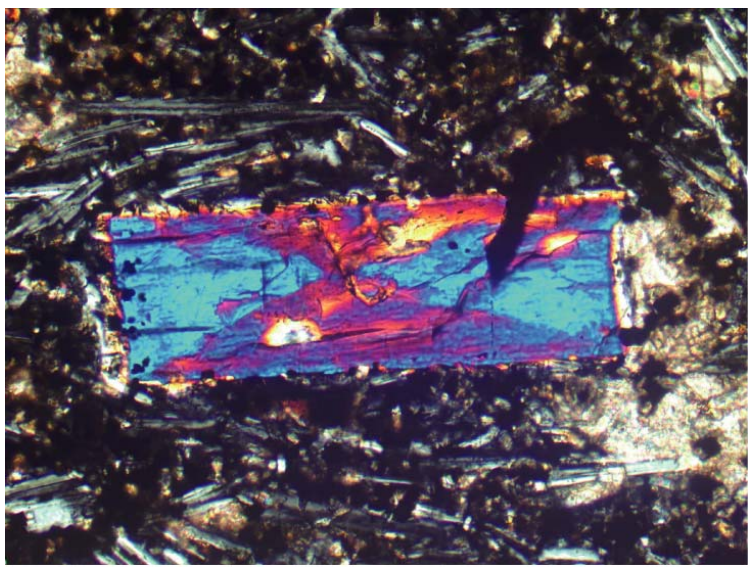

$0.2 \mathrm{~mm}$ 
Figure F16. Downhole variation of (A) color reflectance parameter $\mathrm{a}^{*}$ and (B) alteration color, Hole U1372A. Values of $\mathrm{a}^{*}$ represent relative color position between red (positive) and green (negative). For downhole alteration colors the circles are located at the center depth for each alteration interval. See Figure F12 for an explanation of lithology and stratigraphic units.

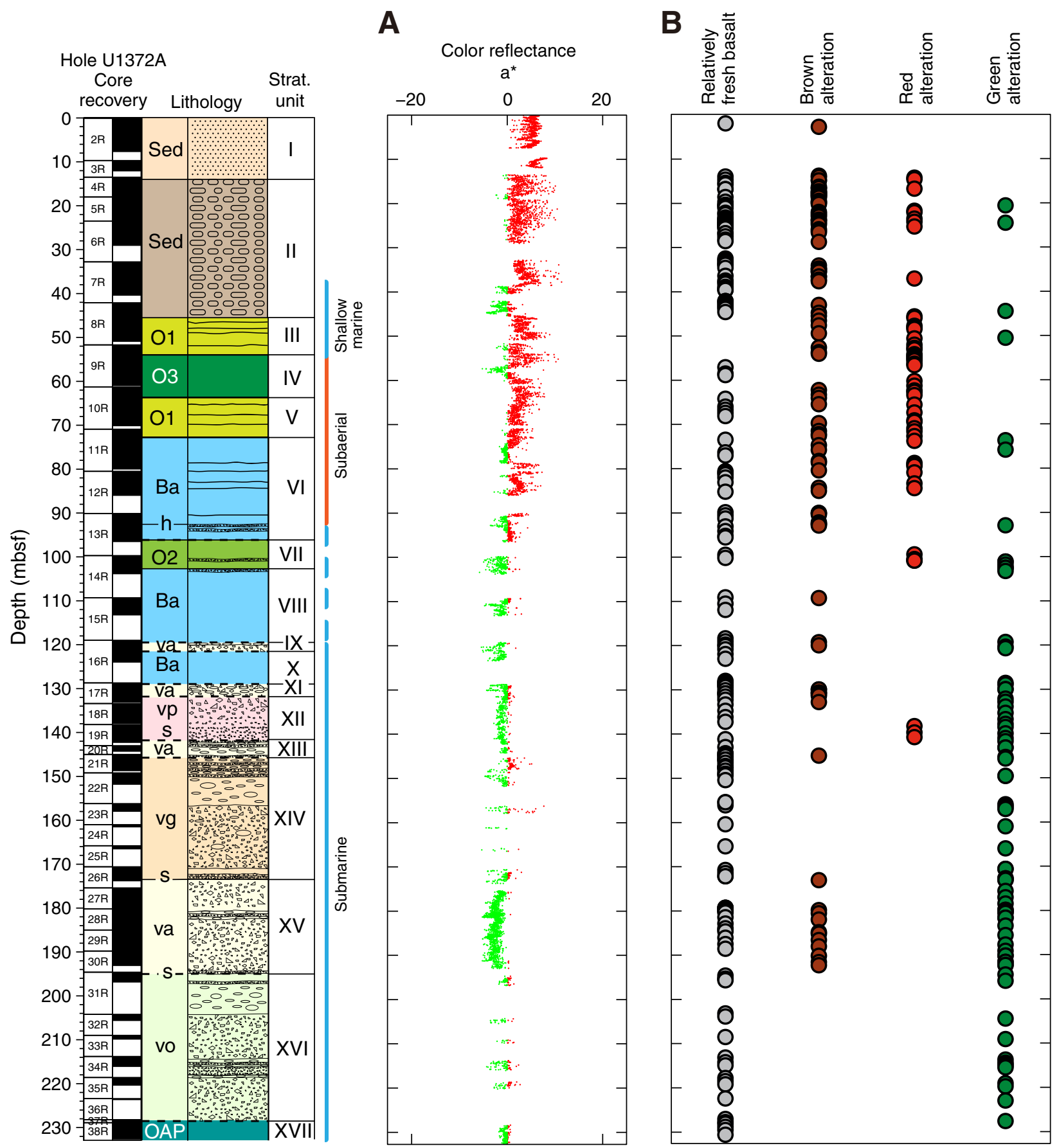


Figure F17. Downhole variation of $(\mathrm{A}) \mathrm{K}_{2} \mathrm{O}$, (B) $\mathrm{Zr} / \mathrm{Ti}$, and (C) $\mathrm{Ni}$ in Site U1372 igneous rocks. Dashed lines = stratigraphic unit boundaries. See Figure F12 for explanation of lithology and stratigraphic units. Note that Site U1372 major element data are normalized to $100 \mathrm{wt} \%$ totals.

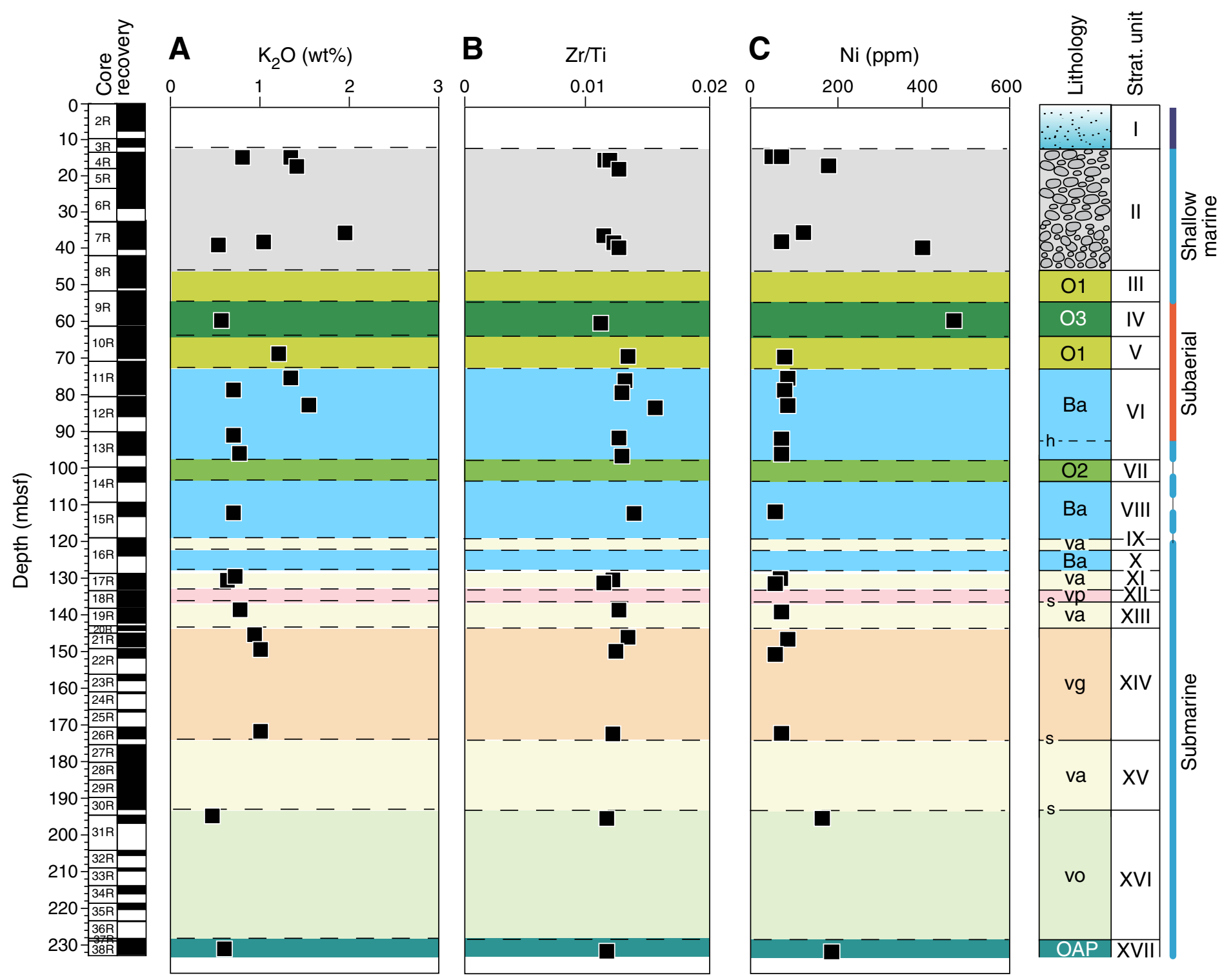


Figure F18. $\mathrm{TiO}_{2}$ vs. (A) $\mathrm{Sr}$ and (B) Y. Note that Site U1372 major element data are normalized to $100 \mathrm{wt} \%$ totals. Data for dredged samples from Louisville Seamount Trail include only samples with LOI $<6 \mathrm{wt} \%$. OJP = Ontong Java Plateau, EPR = East Pacific Rise. See Figure F6 caption for references for data other than Site U1372.

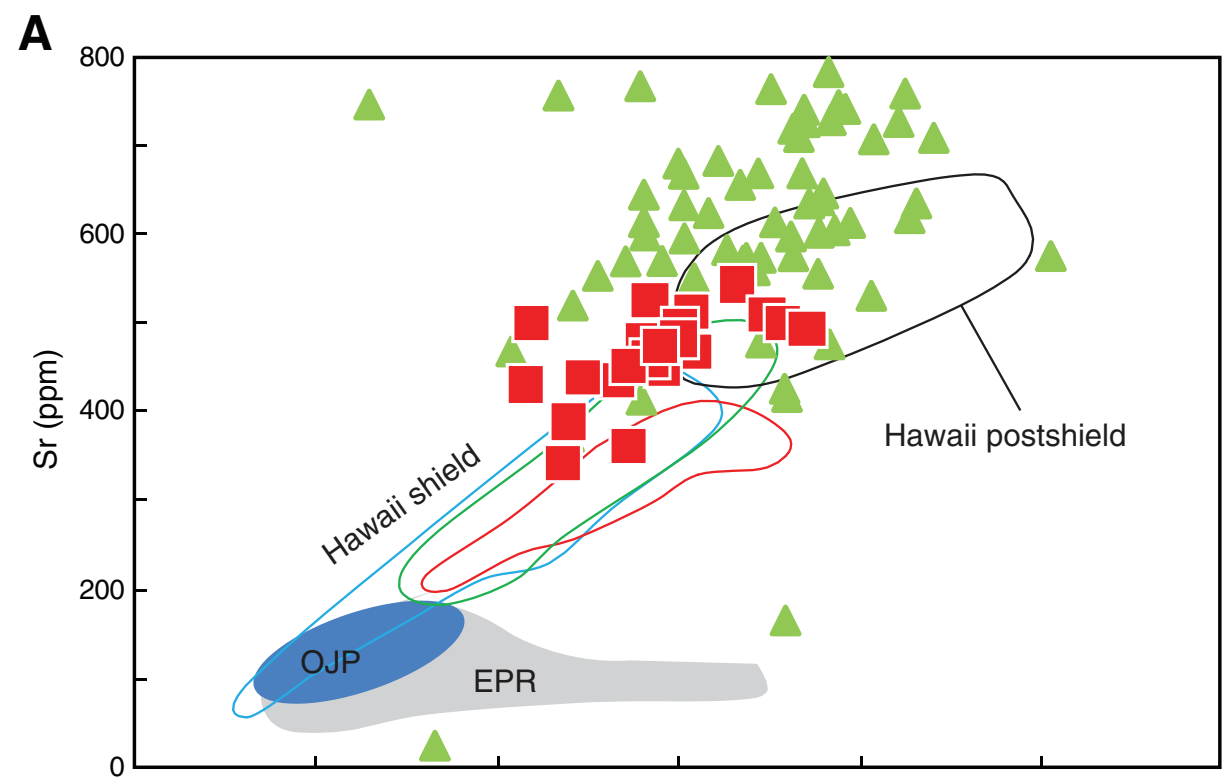

B

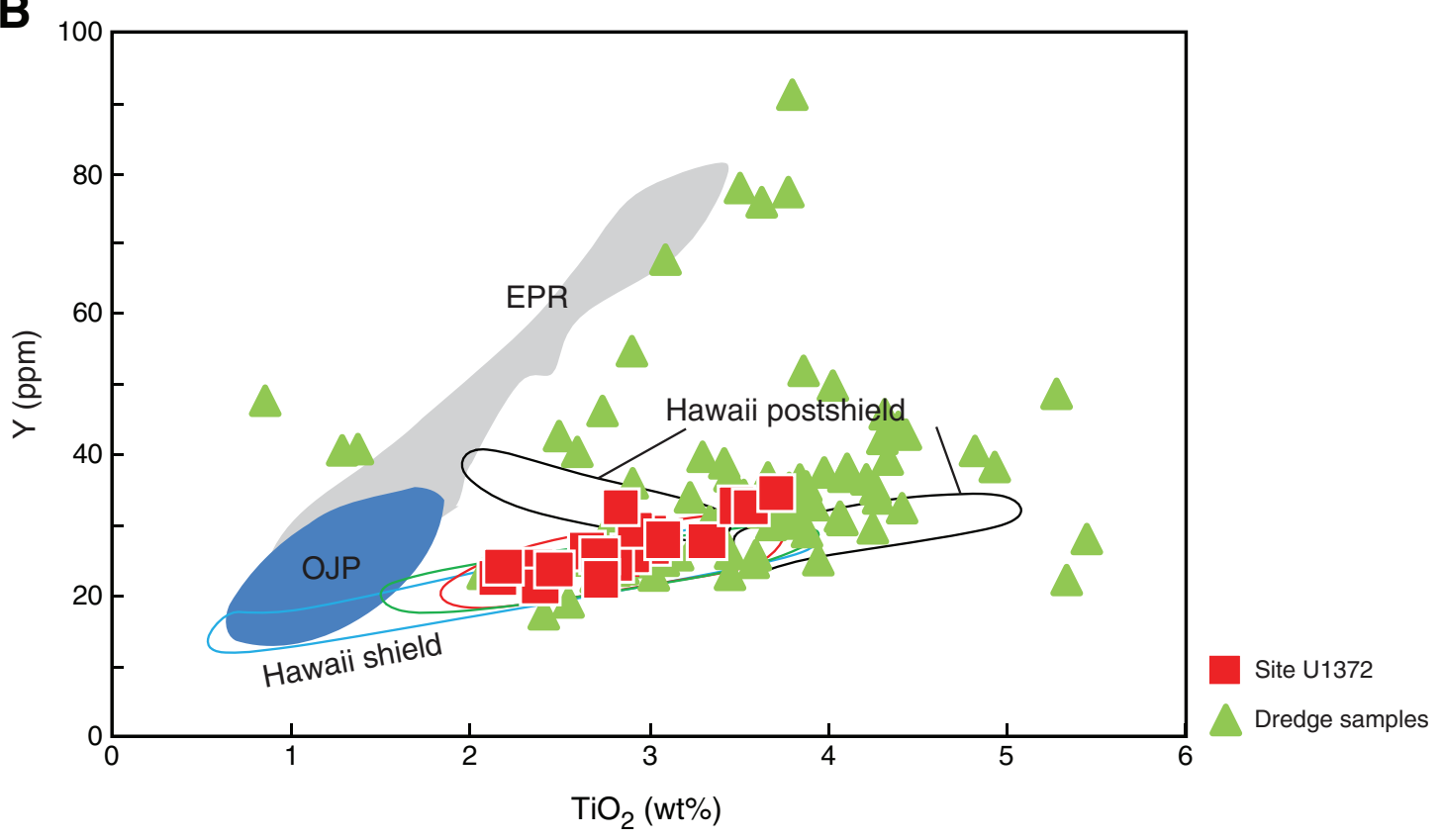


Figure F19. Downhole paleomagnetic data from archive-half cores, Site U1372. A. Core recovery and observed stratigraphy. See Figure F12 for an explanation of lithology and stratigraphic units. B. Downhole remanent intensity, showing natural remanent magnetization (purple) and principal component analysis (PCA) directions below (black) and above (gray) a threshold of fitting quality. C. WRMSL magnetic susceptibility. D. Median destructive field of the vector difference sum $\left(\mathrm{MDF}^{\prime}\right)$, shown only for the more reliable intervals below the threshold of PCA fitting quality.

A

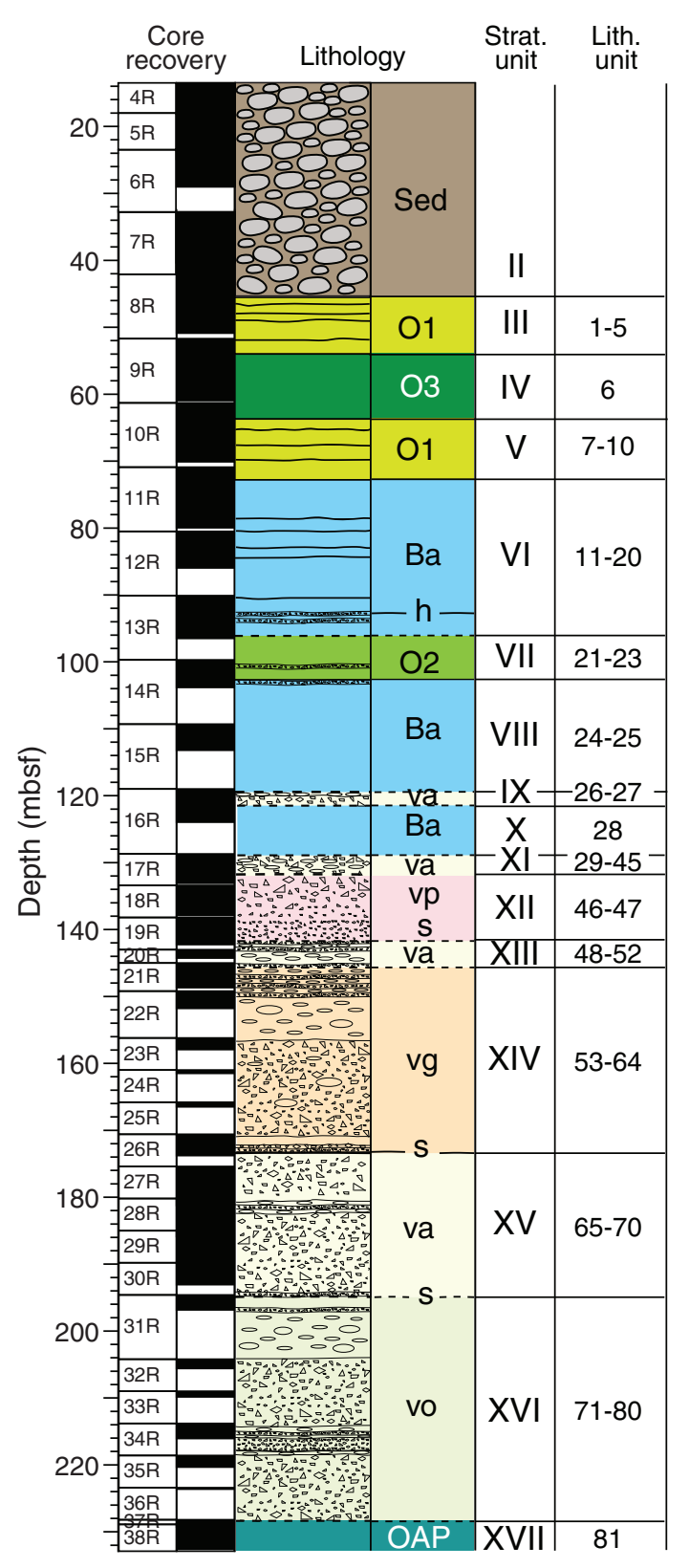

B

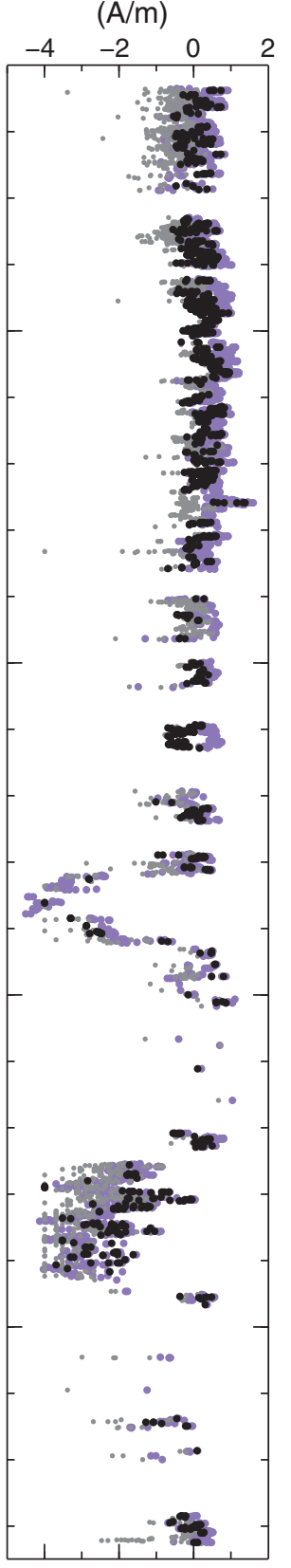

C Log susceptibility $\left(10^{-5} \mathrm{SI}\right)$

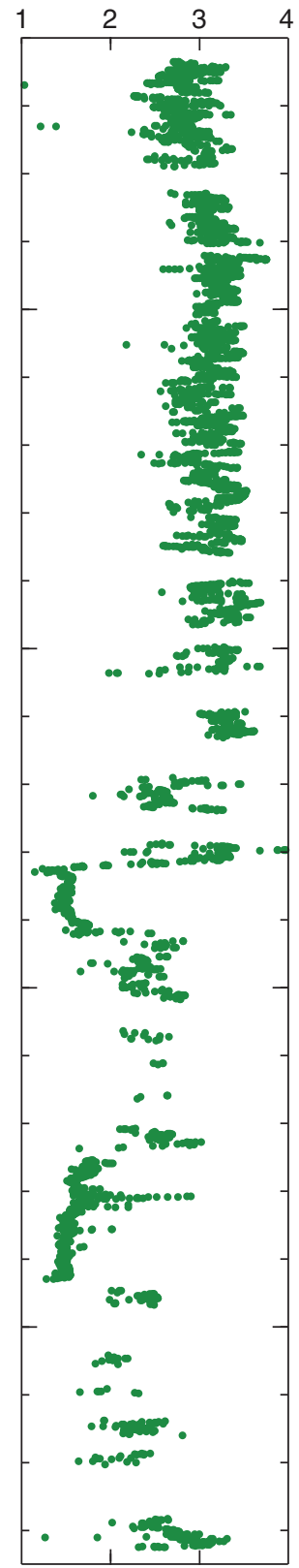

D $\mathrm{MDF}^{\prime}$

(mT)

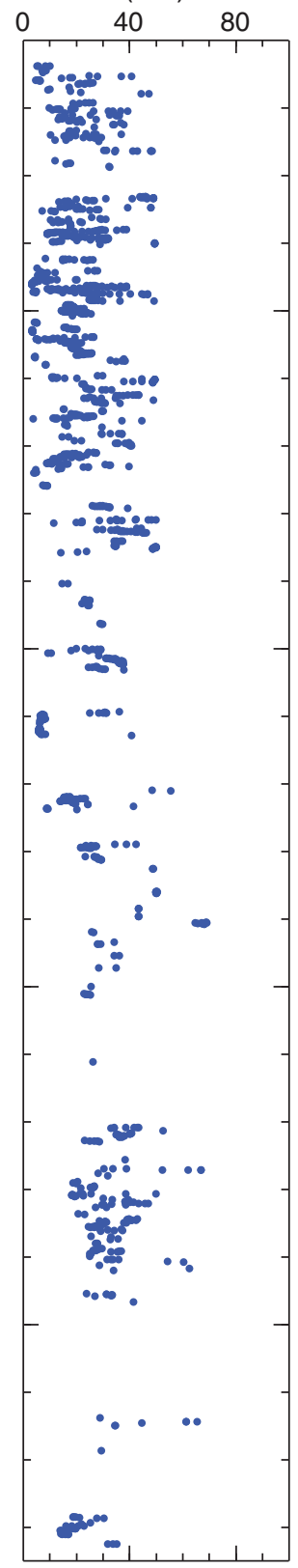


Figure F20. Example of remanent magnetization directions from AF demagnetization of archive half of Section 330-U1372A-14R-2. Directions were determined using principal component analysis (PCA). All PCA directions for this section have misfits below the threshold of PCA fitting quality. Open circles with error bars = pieceaverage directions, triangle = inclination from AF-demagnetized discrete sample. To avoid edge effects, data acquired within $4.5 \mathrm{~cm}$ of either piece end were filtered out.

Section 330-U1372A-14R-2

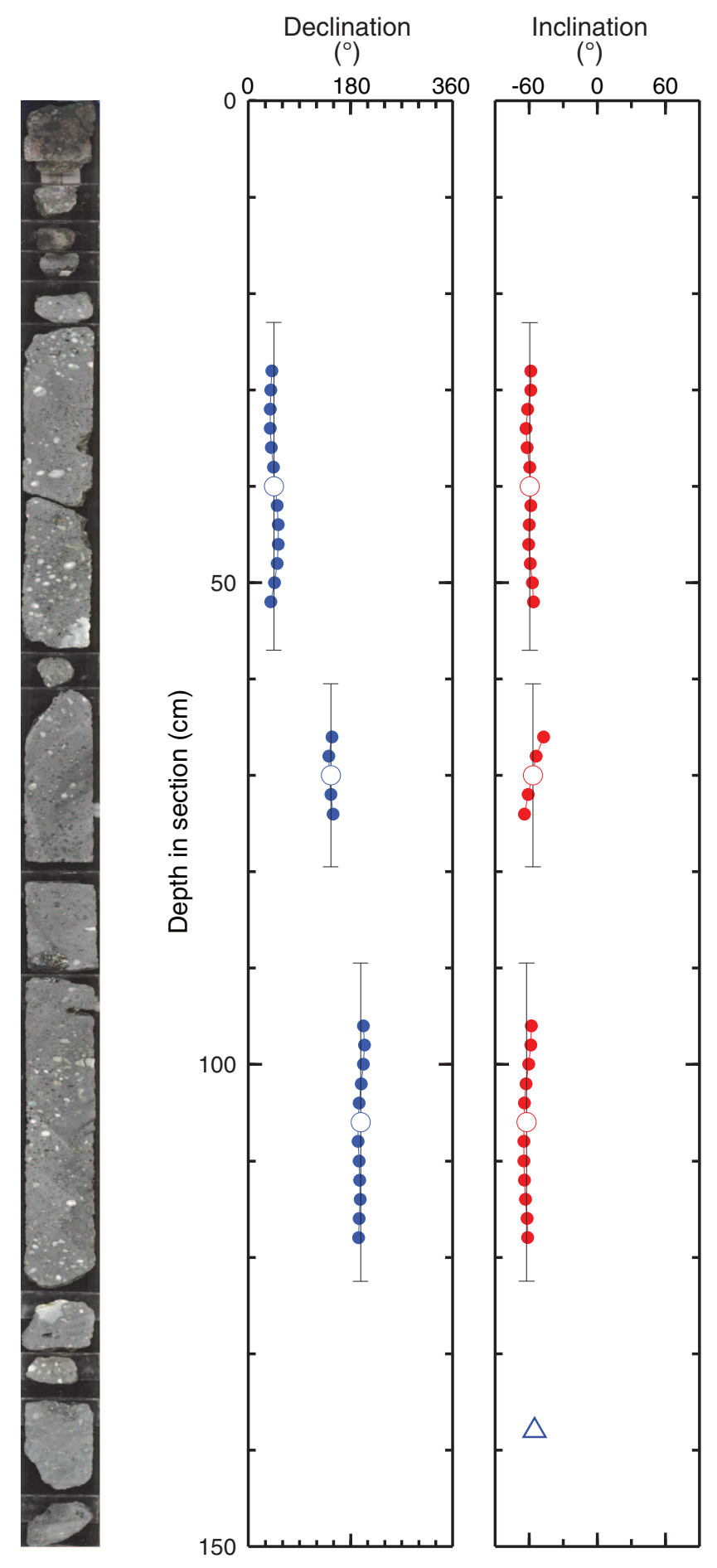


Figure F21. Representative Zijderveld plots of stepwise AF (left) and thermal (right) demagnetization results from adjacent discrete samples within Sections (A) 330-U1372A-13R-4 and (B) 330-U1372A-22R-2. Solid and open circles indicate projections of vector endpoints onto the horizontal and vertical planes, respectively. Red arrows indicate direction derived from principal component analysis. NRM = natural remanent magnetization.

A

Aphyric basaltic lava flow

Sample 330-U1372A-13R-4, 115-117 cm

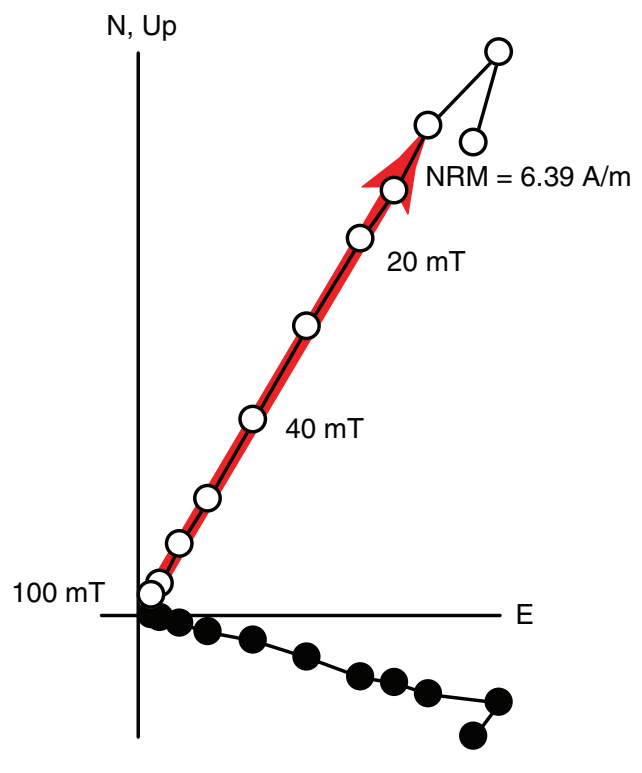

B
Sample 330-U1372A-13R-4, 118-120 cm

$\mathrm{N}$, Up

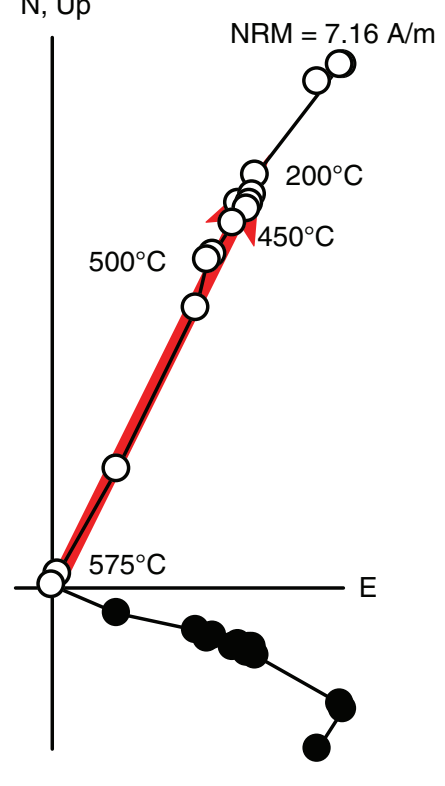

B Aphyric basaltic lava flow within hyaloclastite

Sample 330-U1372A-22R-2, 108-110 cm

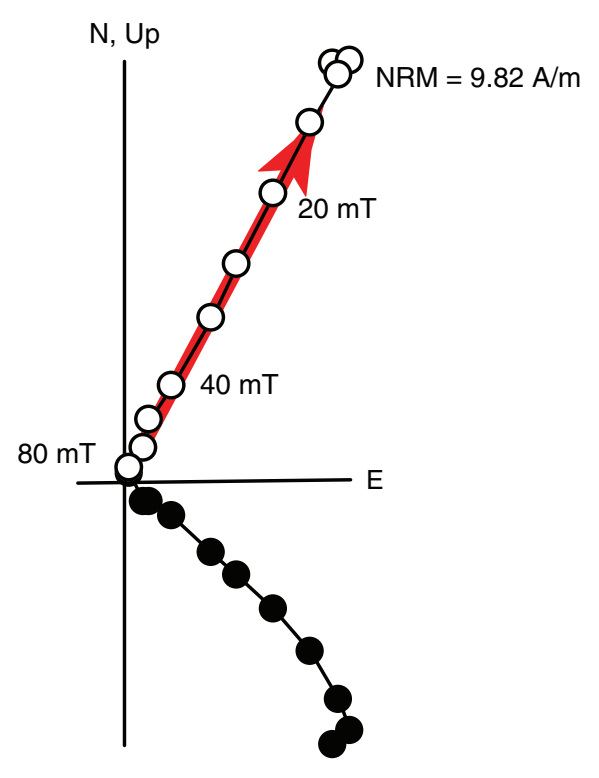

Sample 330-U1372A-22R-2, 105-107 cm

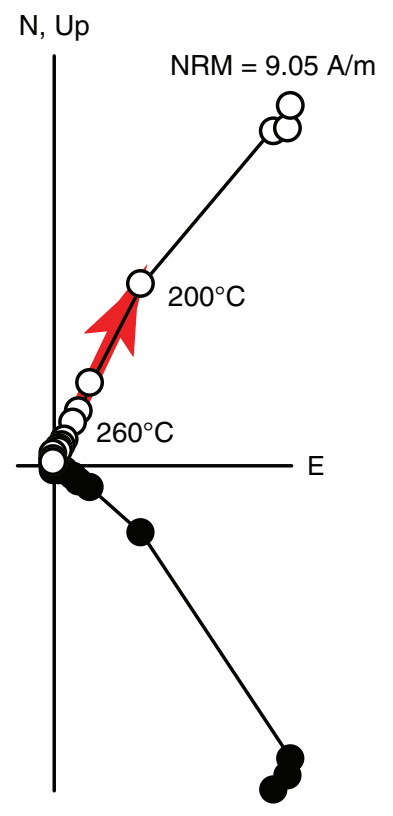


Figure F22. Detailed bathymetric map of Sites U1373 and U1374 on Rigil Guyot and three neighboring guyots or seamounts at $28.2^{\circ} \mathrm{S}, 28.7^{\circ} \mathrm{S}$, and $28.8^{\circ} \mathrm{S}$. GMT-generated bathymetric map is based on SIMRAD EM120 multibeam data collected during the AMAT02RR site survey expedition aboard the R/V Roger Revelle and is merged with global predicted bathymetry (v8.2) from Smith and Sandwell (1997). Dredge locations from previous cruises are indicated by open squares. Crossing multichannel seismic reflection lines collected during the AMAT02RR site survey are shown in blue (for details see Koppers et al., 2010). Map uses a linear projection (i.e., horizontal and vertical scales differ) based on WGS-84.

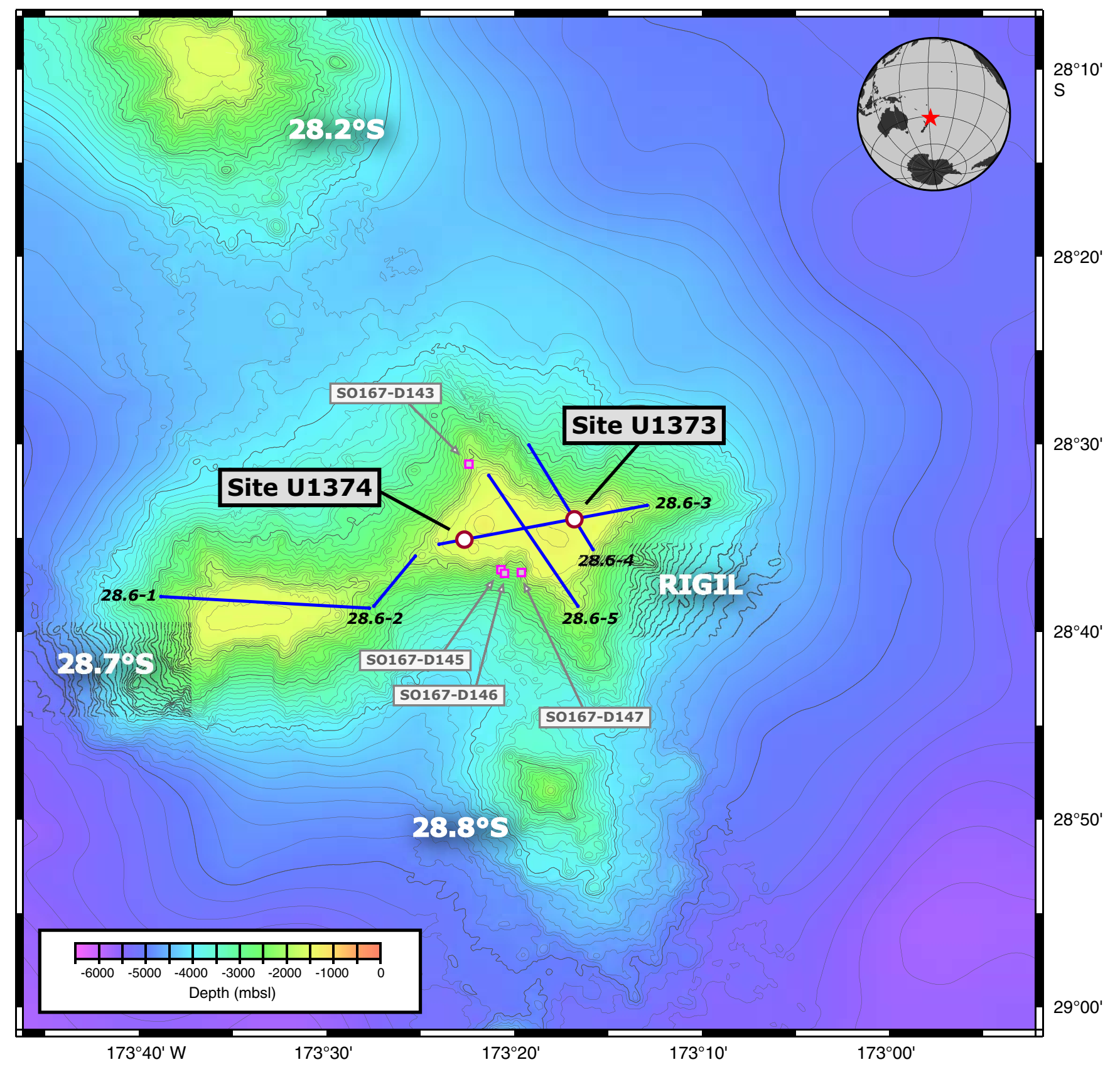


Figure F23. Stratigraphic summary, Hole U1373A. A. Sedimentary sequence. B. Lithology and volcanological features of igneous sequence.

Hole U1373A
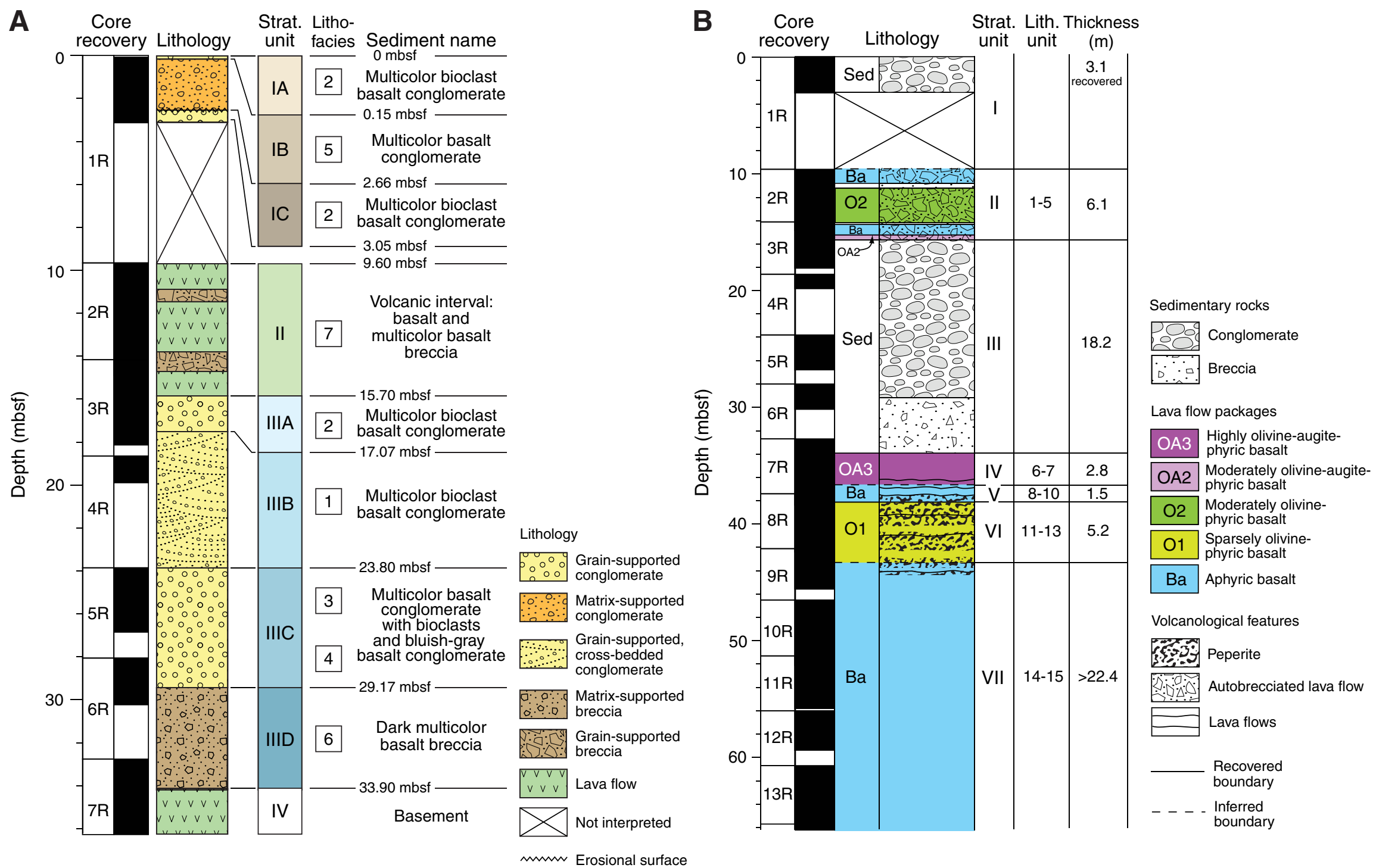
Figure F24. Close-up photographs of select representative lithologies and lithofacies, Site U1373. A. Multicolor basalt breccia (interval 330-U1373A-3R-3, 86-107 cm). B. Peperitic flow top (uppermost $2 \mathrm{~cm}$ ) at upper boundary of $\sim 23 \mathrm{~m}$ thick massive aphyric basalt flow of stratigraphic Unit VII (interval 330-U1373A-9R-2, 83$105 \mathrm{~cm})$.
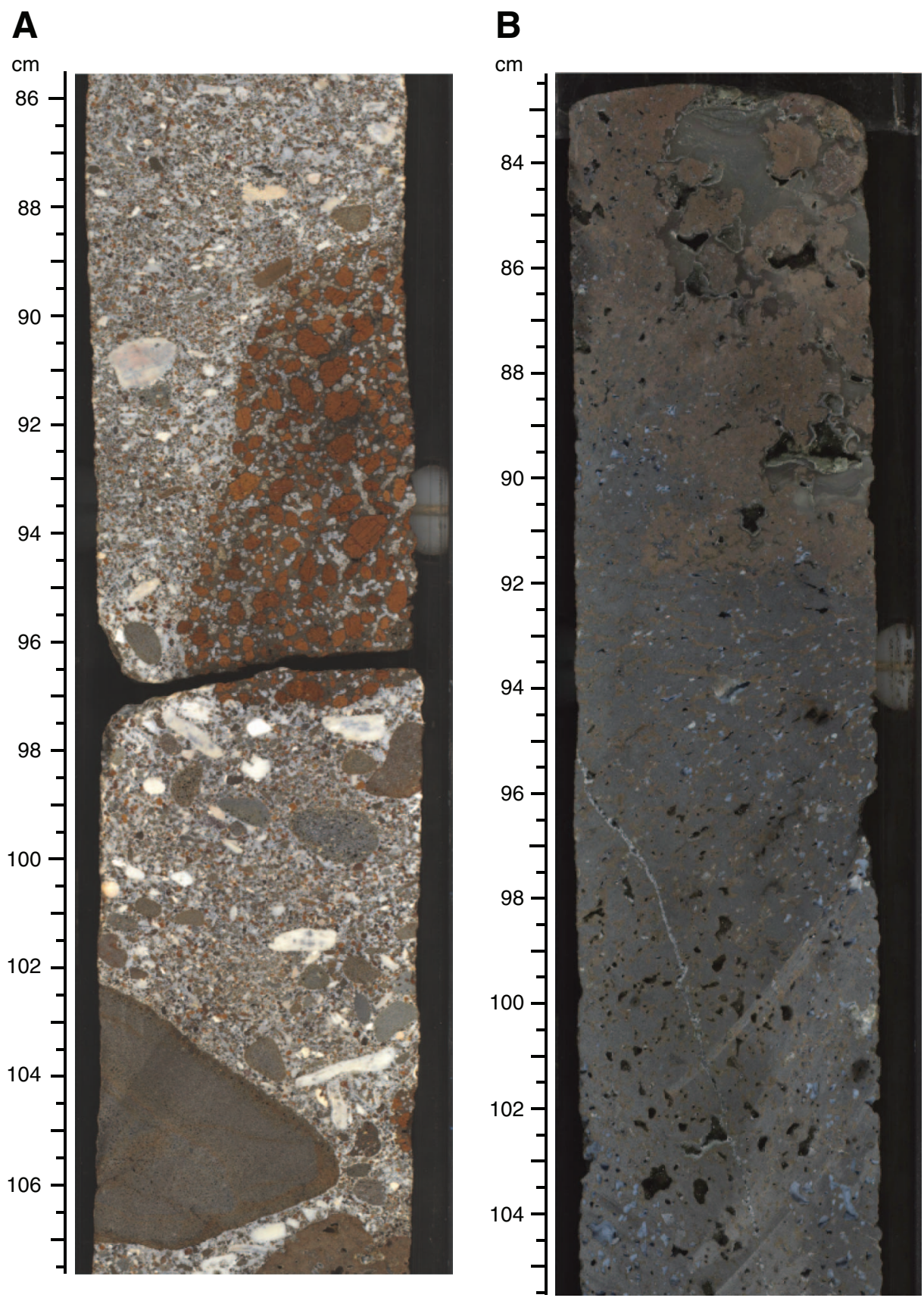
Figure F25. Thin section photomicrographs of microfossils, Site U1373. A. Section of Flemingostrea sp. in Subunit IIIB (Sample 330-U1373A-4R-1, 86-89 cm; Thin Section 85) (plane-polarized light). B. Beach rock including bioclasts and rim cements (Sample 330-U1373A-4R-1, 72-74 cm; Thin Section 84) (with crossed polars). Arrows indicate (1) calcareous algae, (2) bryozoans, and (3) foraminifers.

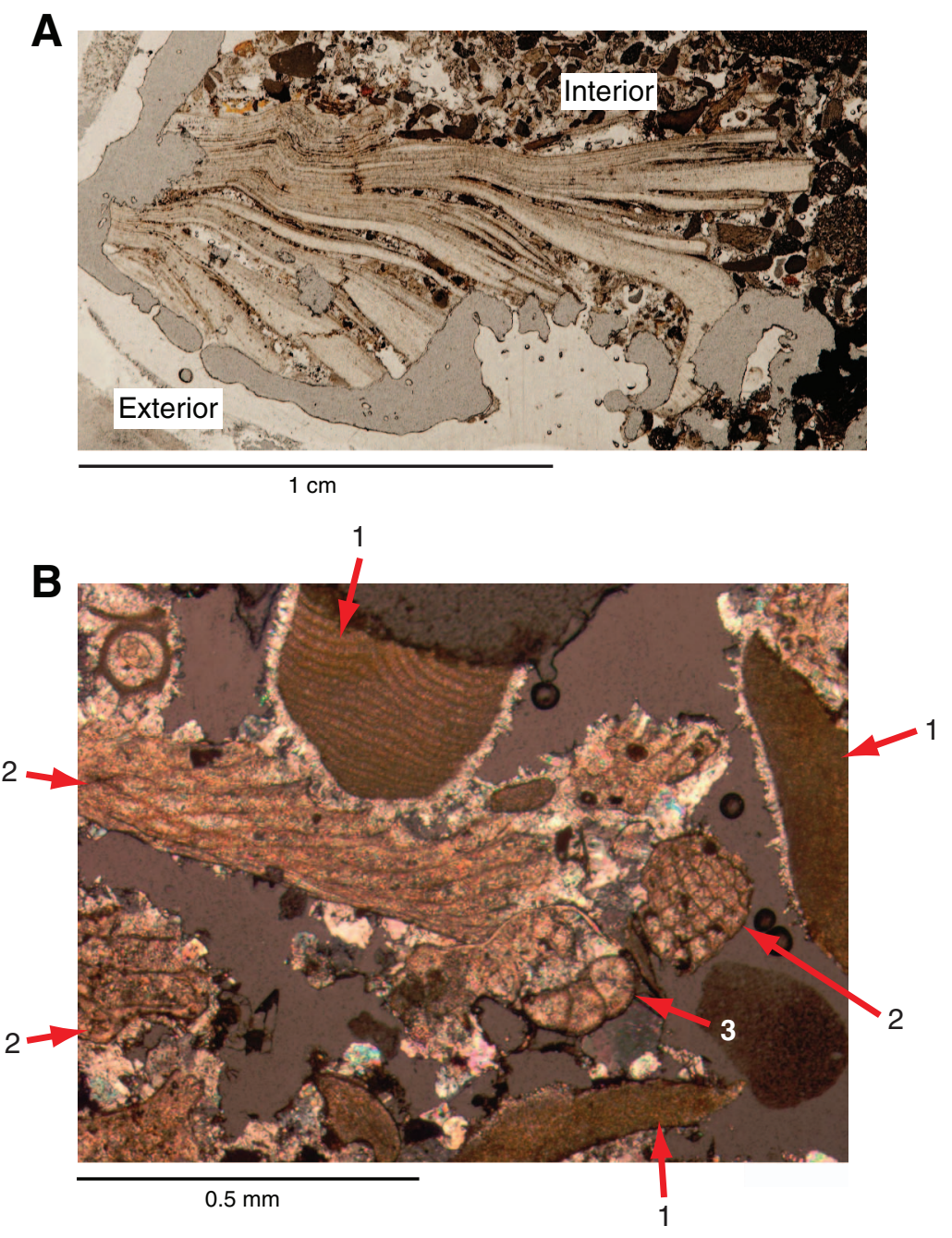


Figure F26. Thin section photomicrographs of basalt, Site U1373. A. Aphyric basalt in $23 \mathrm{~m}$ thick massive flow of Unit VII (Sample 330-U1373A-11R-2, 96-98 cm; Thin Section 104) (with crossed polars). B. Highly olivinetitanaugite-plagioclase-phyric basalt from a Type 7 clast in conglomerate forming Subunit IB (Sample 330U1373A-1R-2, 123-125 cm; Thin Section 76) (with crossed polars). C. Strained olivine crystal (Sample 330U1373A-1R-2, 123-125 cm; Thin Section 76) (with crossed polars). D. Ti-augite phenocryst in highly olivineaugite phyric basalt recovered from the middle of Unit II (Sample 330-U1373A-7R-1, 84-86 cm; Thin Section 89) (with crossed polars).

A

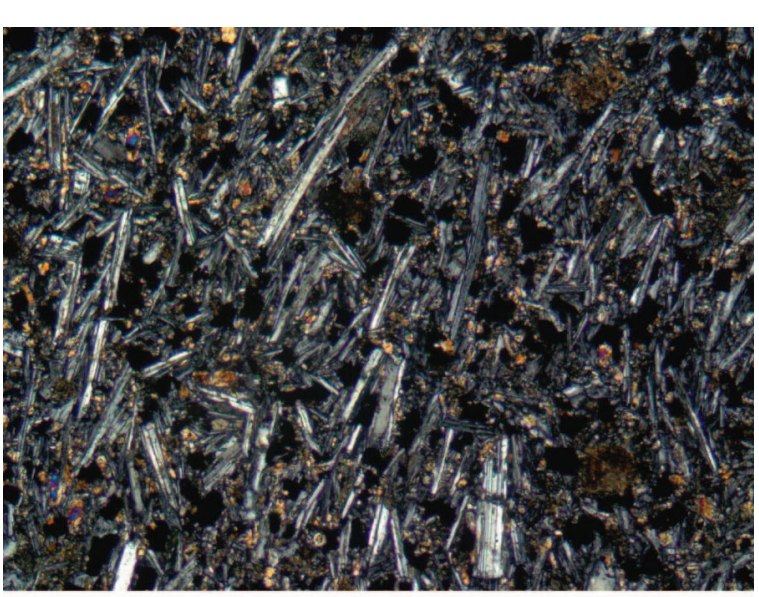

$0.5 \mathrm{~mm}$

\section{C}

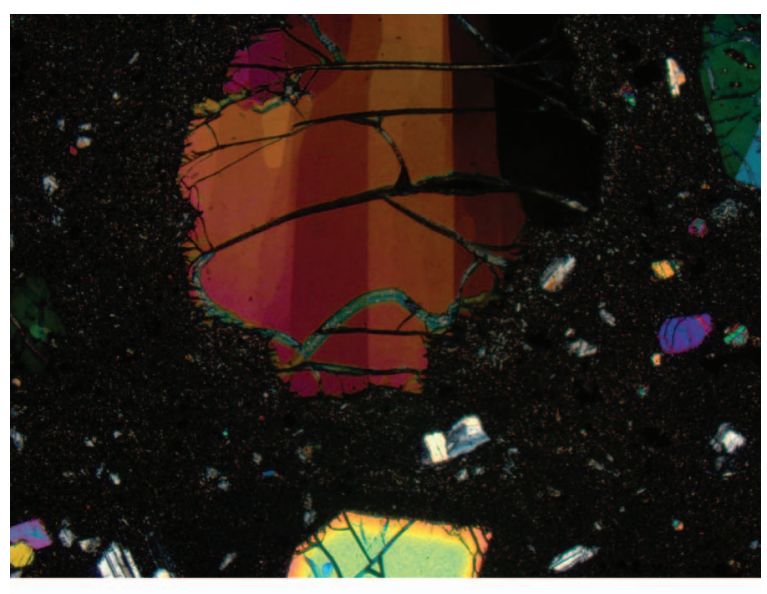

$0.5 \mathrm{~mm}$
B

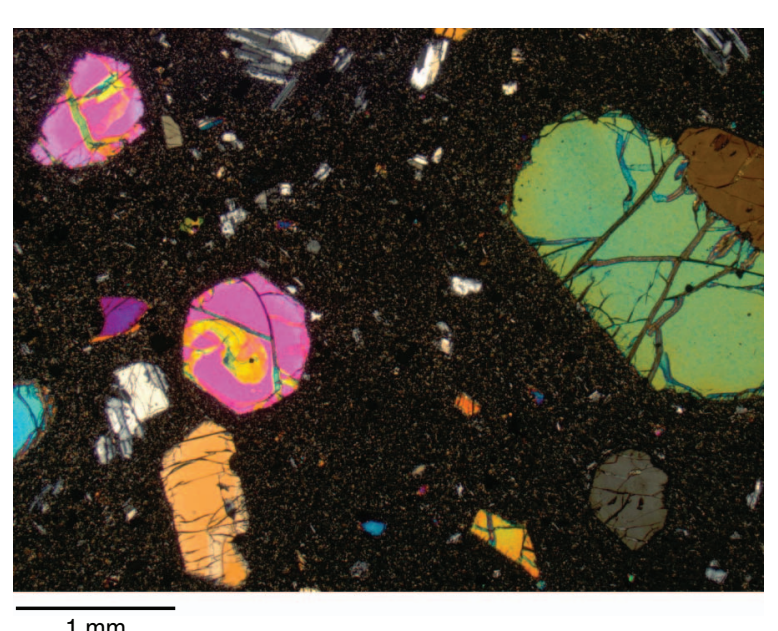

D

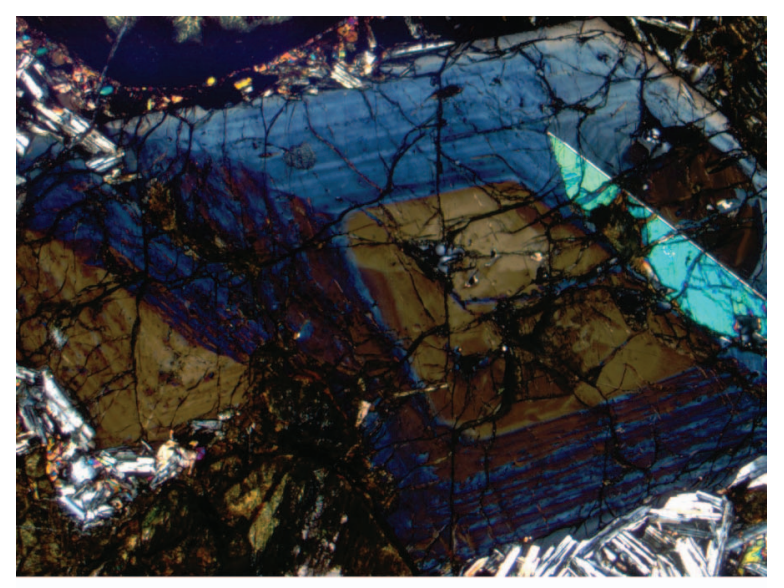

$1 \mathrm{~mm}$ 
Figure F27. Downhole variation of (A) color reflectance parameter $a^{*}$ and (B) alteration color, Hole U1373A. Values of $\mathrm{a}^{*}$ represent relative color position between red (positive) and green (negative). For downhole alteration colors the circles are located at the center depth for each alteration interval. See Figure F23 for an explanation of lithology and stratigraphic units.

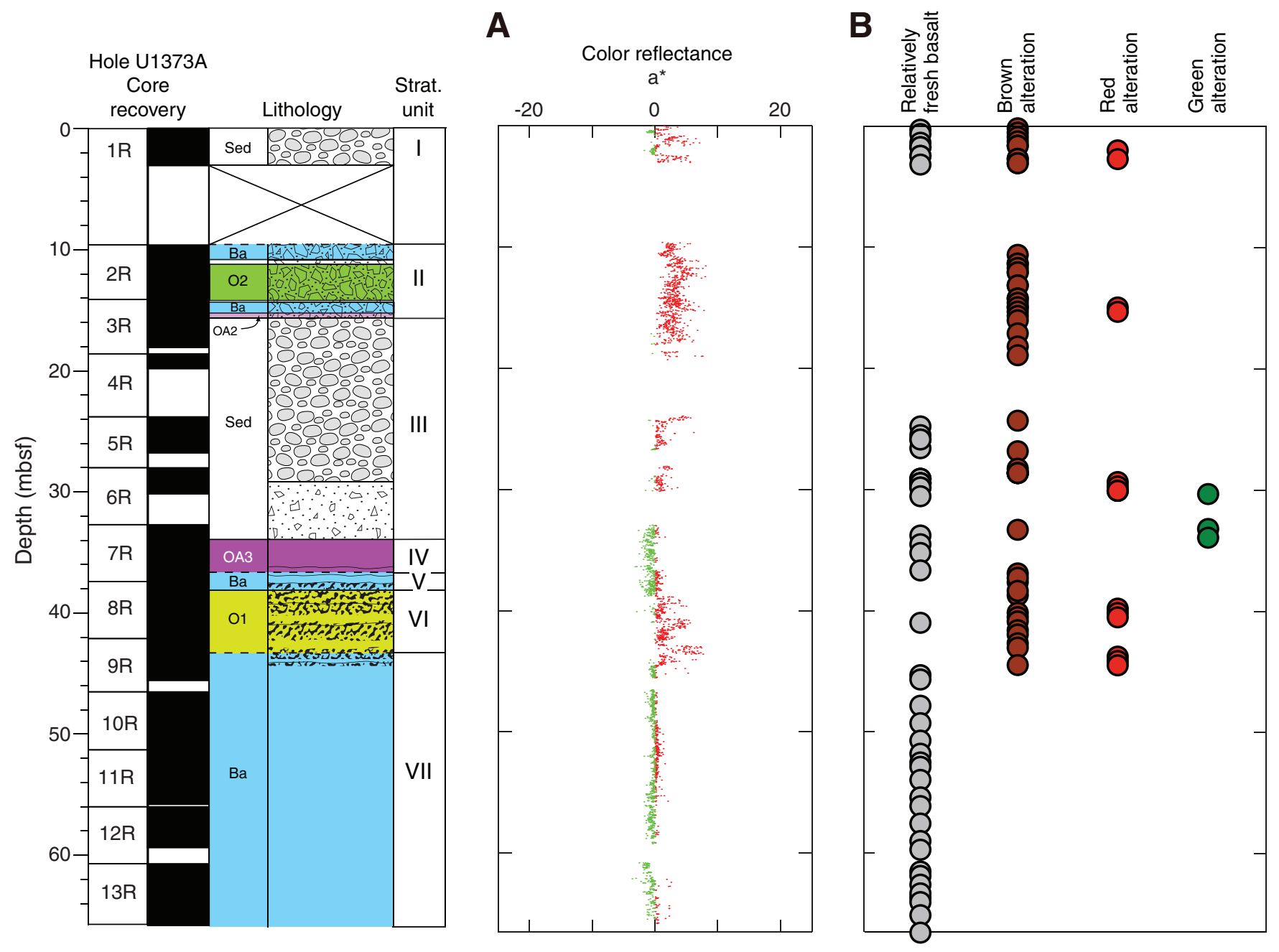


Figure F28. Downhole variation of (A) Mg\#, (B) Ni, and (C) Zr/Ti in Site U1373 igneous rocks. Dashed lines = stratigraphic unit boundaries. See Figure F23 for explanation of lithology and stratigraphic units. Note that Site U1373 major element data are normalized to $100 \mathrm{wt} \%$ totals.
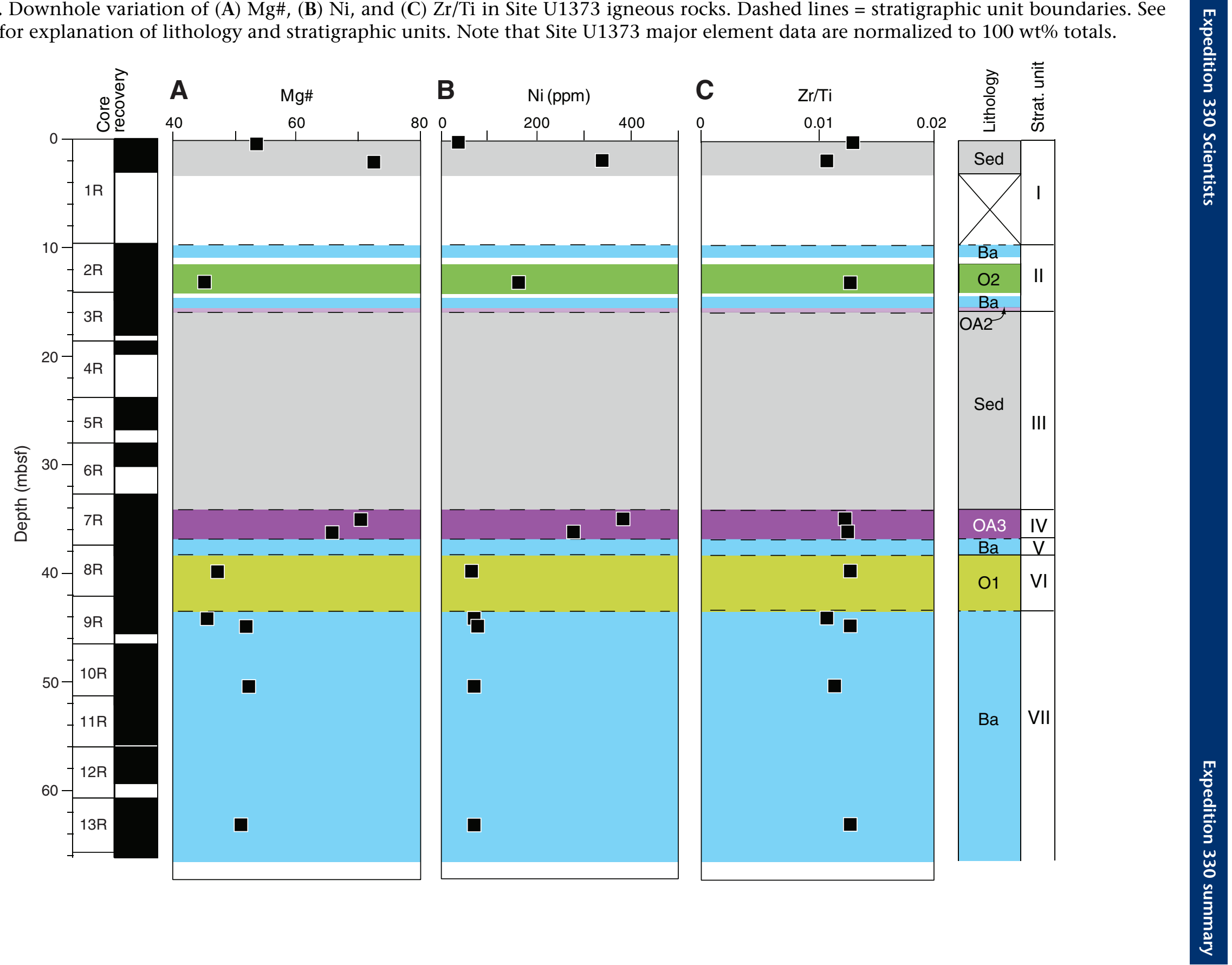
Figure F29. $\mathrm{TiO}_{2}$ vs. (A) Sr and (B) Y. Note that Site U1373 major element data are normalized to 100 wt $\%$ totals. Data for dredged samples from Louisville Seamount Trail include only samples with LOI $<6 \mathrm{wt} \%$. OJP = Ontong Java Plateau, EPR = East Pacific Rise. See Figure F6 caption for references for data other than Site U1373.
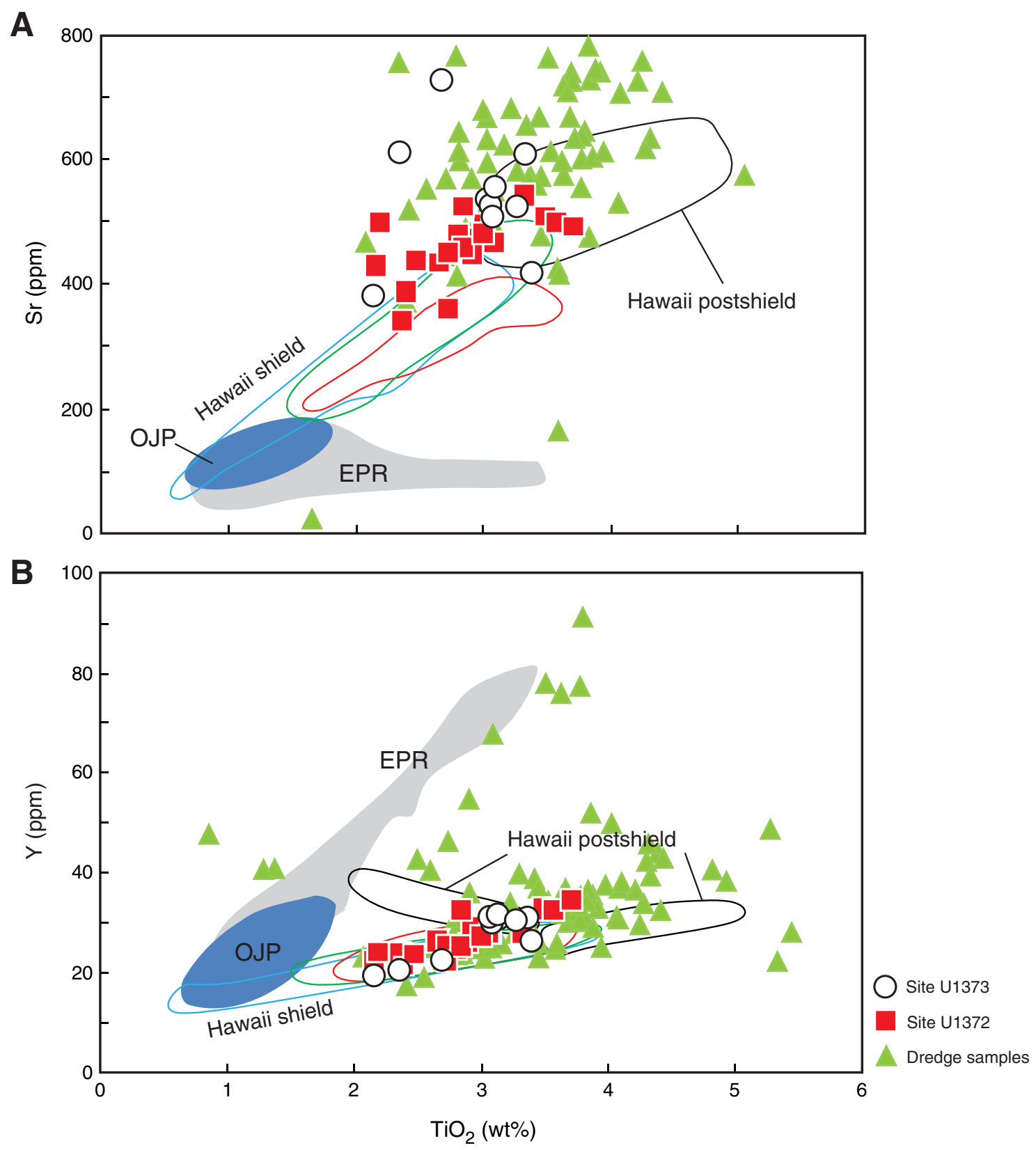
Figure F30. Downhole paleomagnetic data from archive-half cores, Site U1373. A. Core recovery and observed stratigraphy. See Figure F23 for explanation of lithology and stratigraphic units. B. Downhole remanent intensity, showing natural remanent magnetization (purple) and principal component analysis (PCA) directions below (black) and above (gray) threshold of PCA fitting quality. C. WRMSL magnetic susceptibility. D. Median destructive field of the vector difference sum $\left(\mathrm{MDF}^{\prime}\right)$.

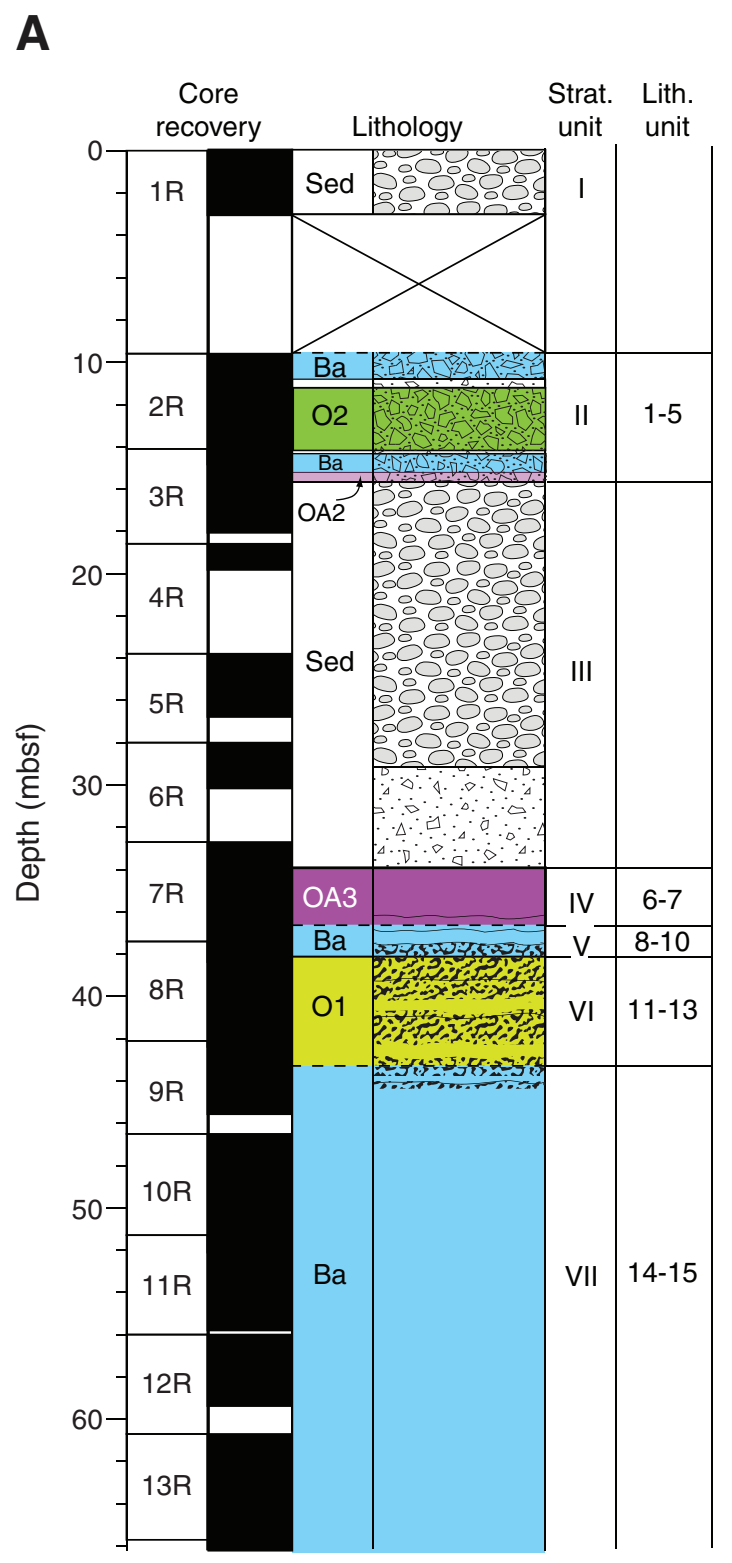

B $\underset{(\mathrm{A} / \mathrm{m})}{\log \text { intensity }}$

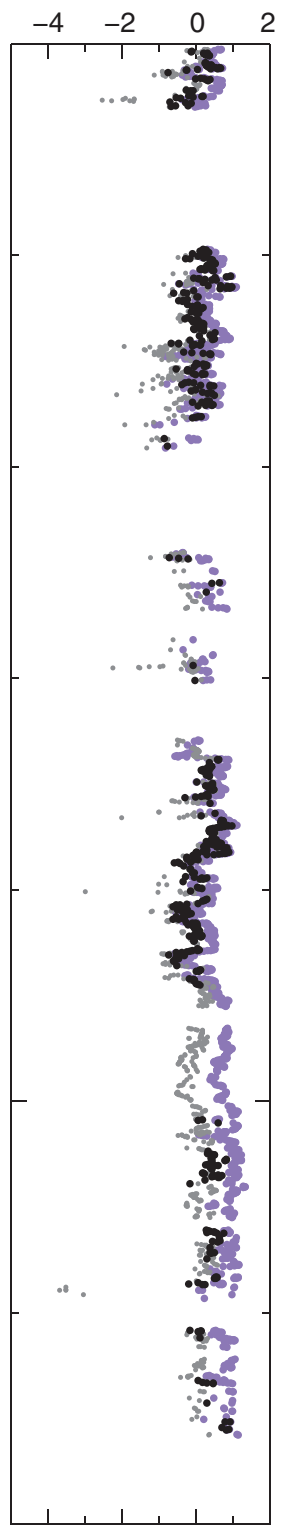

C Log susceptibility

$\left(10^{-5} \mathrm{SI}\right)$

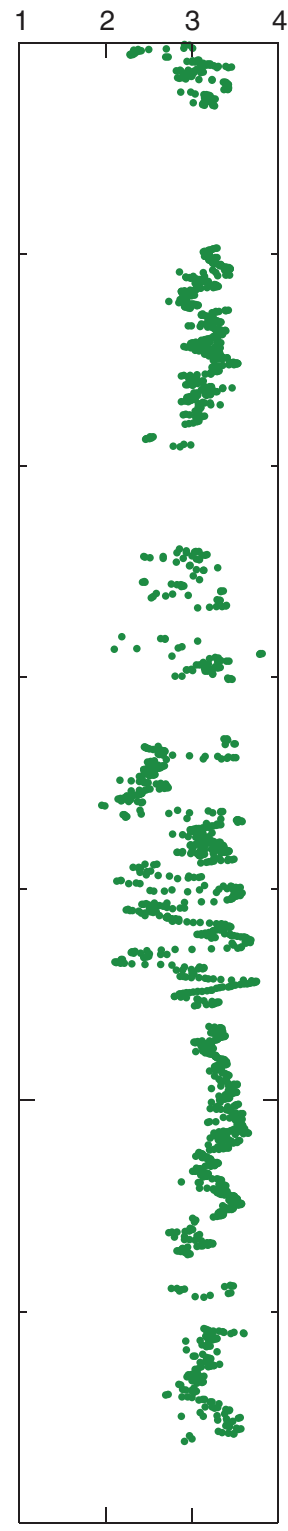

D $\mathrm{MDF}^{\prime}$

(mT)

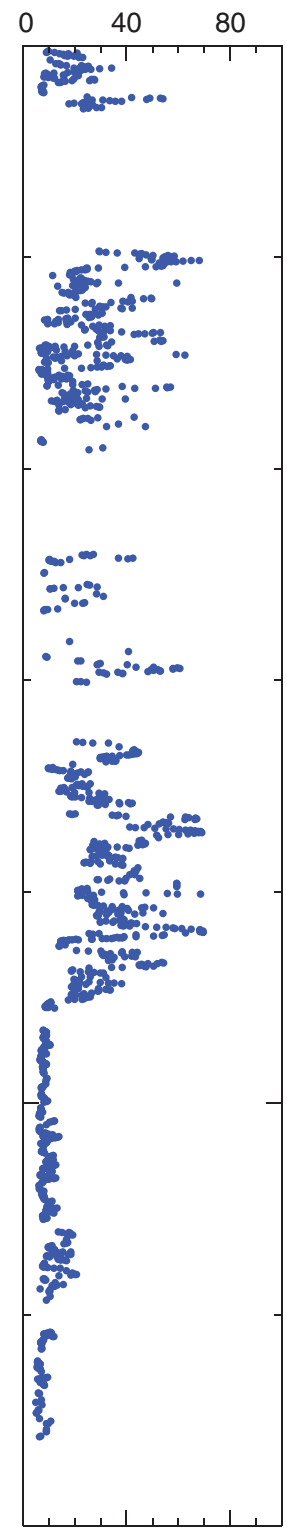


Figure F31. Example of remanent magnetization directions from AF demagnetization of archive half of Section 330-U1373A-7R-2. Directions were determined using principal component analysis (PCA). Dark blue = declinations for PCA directions with misfits below threshold of PCA fitting quality, light blue = declinations with misfits above threshold. Dark red = inclinations for PCA directions with misfits below threshold of PCA fitting quality, light red = inclinations with misfits above threshold. Open circles with error bars = piece-average directions, triangle = inclination from AF-demagnetized discrete sample, square = inclination from thermally demagnetized discrete sample. To avoid edge effects, data acquired within $4.5 \mathrm{~cm}$ of either piece end were filtered out.

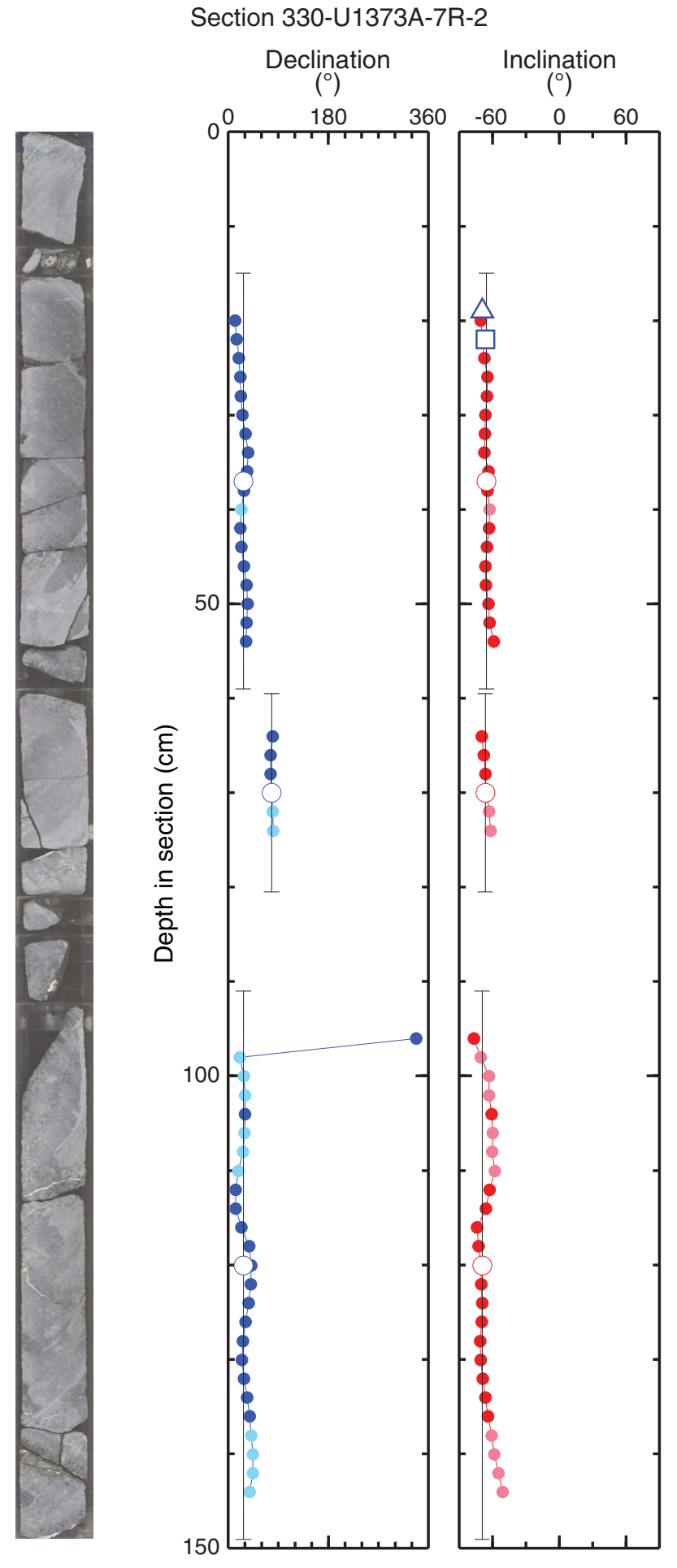


Figure F32. Representative Zijderveld plots by rock type for stepwise (A, C) thermal and (B, D) AF demagnetization results of discrete samples taken from stratigraphic Units II and IV-VI, Hole U1373A. Solid and open circles indicate projections of vector endpoints onto the horizontal and vertical planes, respectively. Red arrows indicate direction derived from principal component analysis. NRM = natural remanent magnetization.

A

Unit II: Volcanic breccia

Sparsely olivine-phyric basalt breccia Sample 330-U1373A-3R-1, 55-57 cm

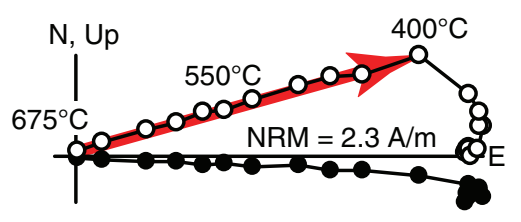

C Unit V: Aphyric basalt peperite

Sample 330-U1373A-7R-4, 128-130 cm

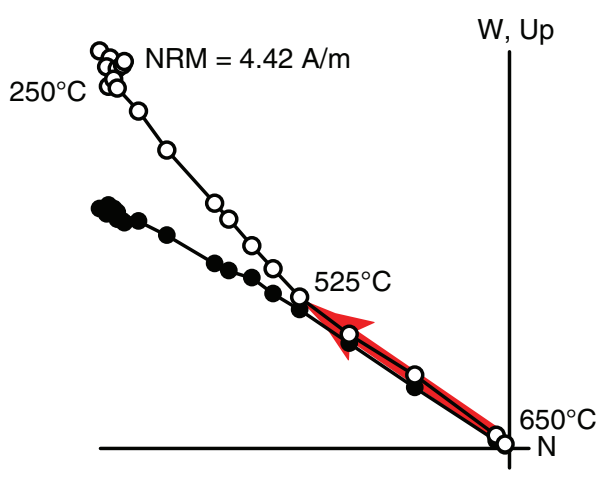

B Unit IV: Massive lava flow

Sample 330-U1373A-7R-3, 5-7 cm

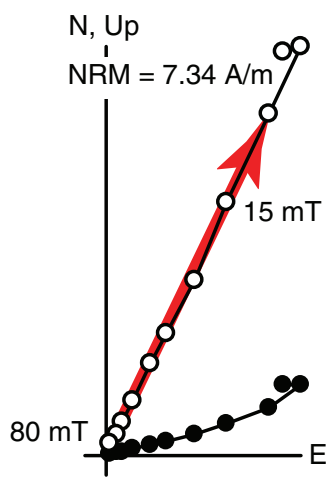

Unit VI: Peperitic lava flow

Sample 330-U1373A-8R-2, 67-69 cm

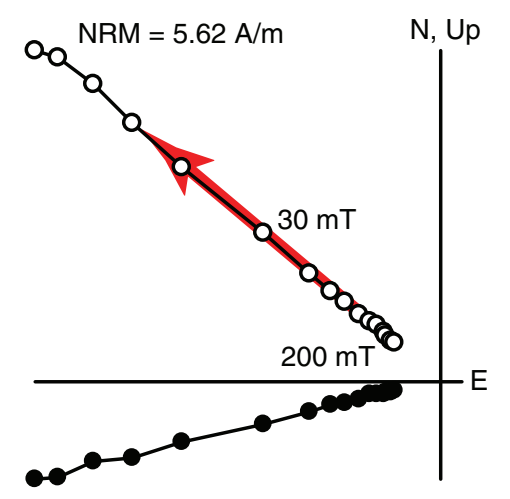



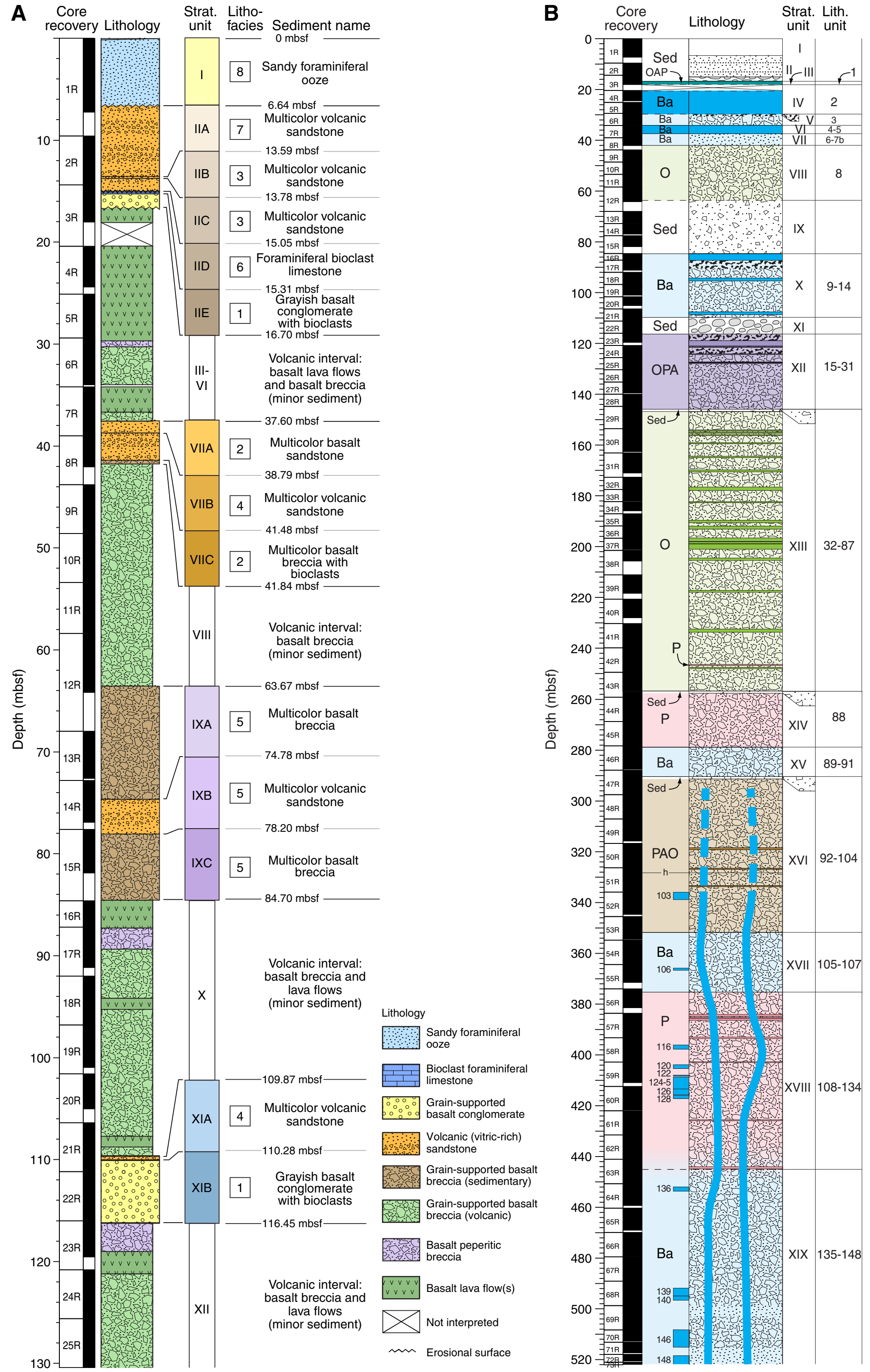
Figure F34. Close-up photographs of selected representative lithologies and lithofacies, Site U1374. A. Multicolor volcanic sandstone in Subunit IIA interpreted as air-fall volcanic products emplaced in a submarine environment with limited postdepositional reworking (interval 330-U1374A-2R-2, 89-129 cm). B. Grayish basalt conglomerate with bioclasts in Subunit IIE deposited in an intertidal to subtidal environment and believed to represent the first sedimentary record after or during the flattening of the top of Rigil Guyot at Site U1374 (interval 330-U1374A-3R-2, 25-65 cm). C. Multicolor volcanic sandstone in Subunit VIIB interpreted to have been emplaced on a shallow-marine slope as a hyperconcentrated flow (interval 330-U1374A-8R-1, 10-50 cm). D, E. Examples of magma-sediment (peperitic) interaction observed in Hole U1374A: (D) interval 330-U1374A17R-3, 20-40 cm, and (E) interval 330-U1374A-23R-2, 107-127 cm. F. Poorly sorted breccia with irregular scoriaceous clasts that probably formed in a hydrovolcanic eruption (interval 330-U1374A-29R-1, 76-90 cm). G. Angular aphyric basalt clasts in hyaloclastite matrix (interval 330-U1374A-66R-6, 55-69 cm). H. Example of dike margins recovered in Hole U1374A: peperitic sheet margin in contact with hyaloclastite breccia (interval 330-U1374A-60R-1, 91-129 cm). (Figure shown on next page.) 


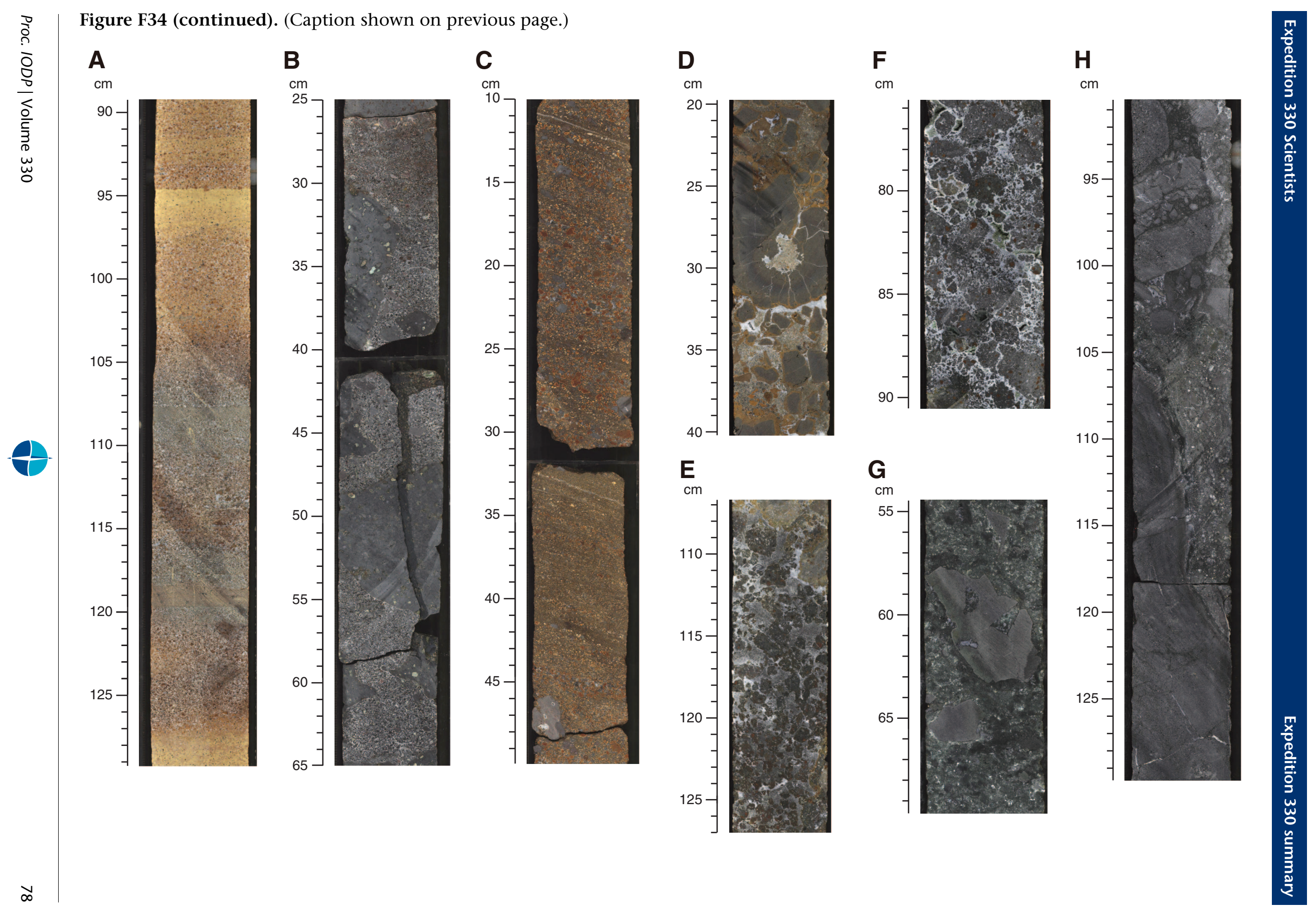


Figure F35. Thin section photomicrographs of microfossils, Site U1374. A. Planktonic foraminifer Globotruncanita cf. conica (Sample 330-U1374A-2R-4, 27-32 cm; Thin Section 111). B. Geopetal structure in foraminiferal bioclast limestone (Sample 330-U1374A-3R-1, 70-72 cm; Thin Section 113) (plane-polarized light). Mold of dissolved shell fragment can be seen, including (1) vadose silt and (2) dogtooth and granular cements. Dissolution of shells and vadose cements occurred probably after the lithification of the limestone. Arrow points toward top.

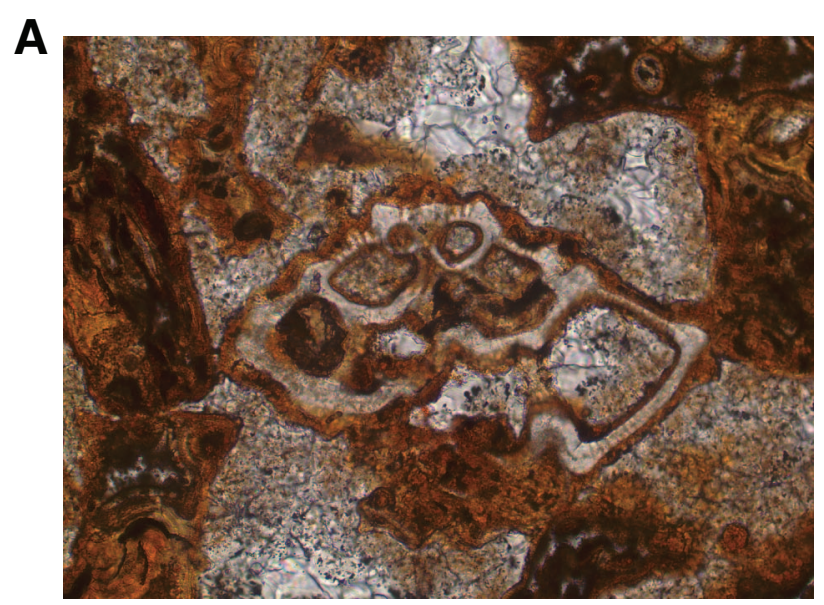

$100 \mu \mathrm{m}$
B

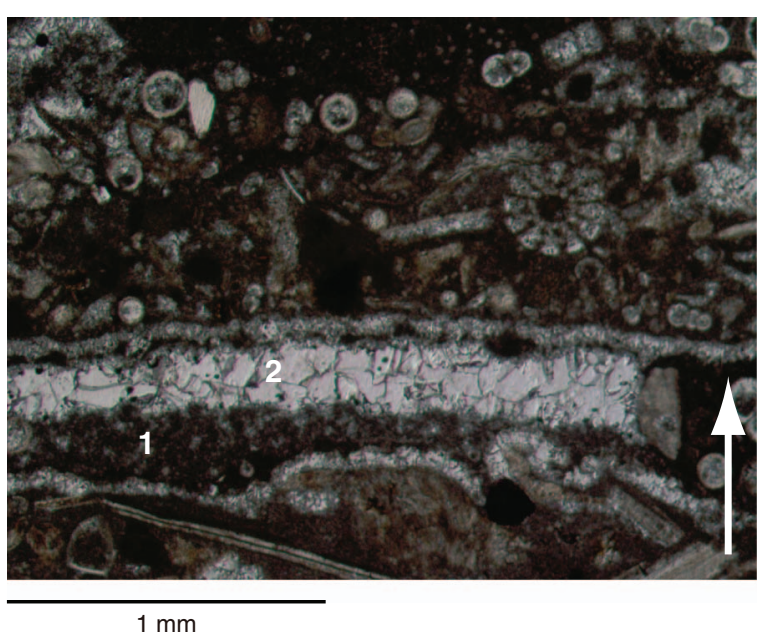


Figure F36. Thin section photomicrographs of basalt, Site U1374. Highly olivine-augite-plagioclase-phyric basalt from Unit III showing large olivine, titanaugite, and small plagioclase phenocrysts (A) under plane-polarized light and (B) with crossed polars (Sample 330-U1374A-3R-2, 108-110 cm; Thin Section 118). C. Aphyric basalt from Unit $X$ showing glassy groundmass, unaltered groundmass olivine, and flow-aligned plagioclase laths (Sample 330-U1374A-19R-1, 50-53 cm; Thin Section 147) (plane-polarized light). D. Highly olivine-plagioclase-augite-phyric basalt from Unit XII. Large plagioclase phenocrysts are abundant in this unit and are often partly resorbed and filled with interconnecting inclusions of dark glass (Sample 330-U1374A-24R-1, 77$80 \mathrm{~cm}$; Thin Section 158) (plane-polarized light).
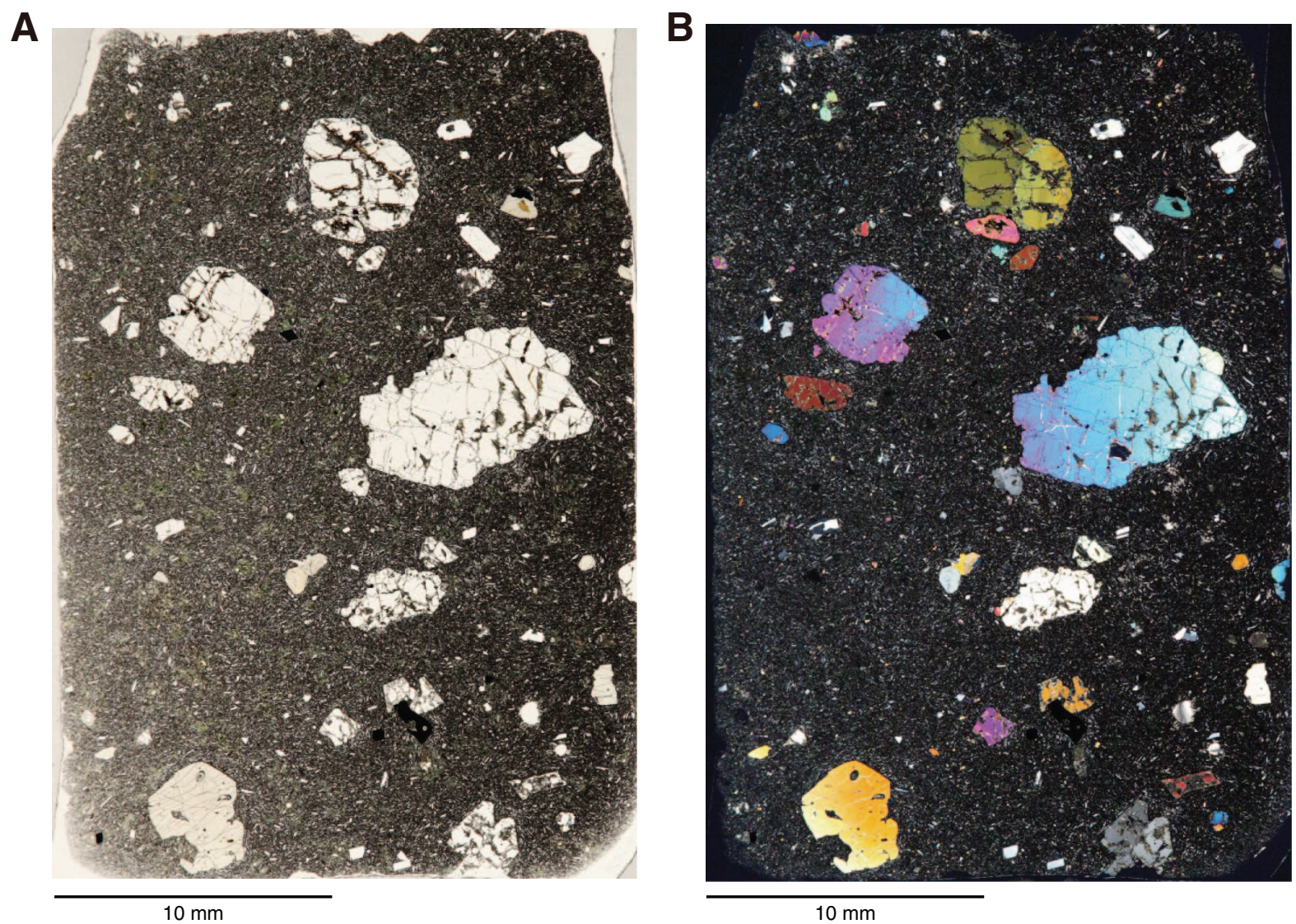

$10 \mathrm{~mm}$

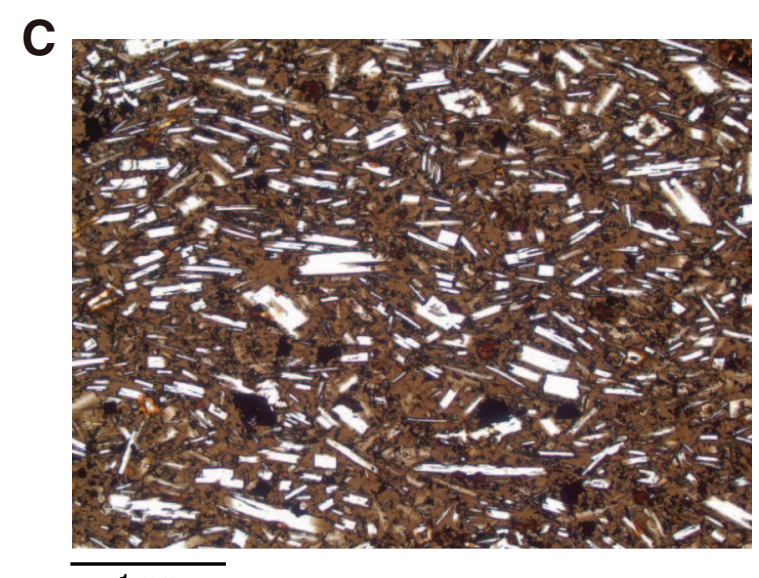

D

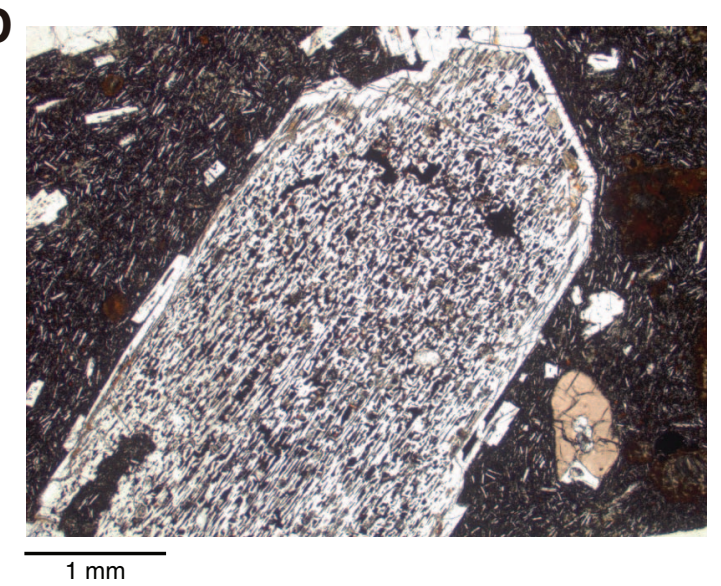


Figure F37. Downhole variation of (A) color reflectance parameter $\mathrm{a}^{*}$ and (B) alteration color, Hole U1374A. Values of $\mathrm{a}^{*}$ represent relative color position between red (positive) and green (negative). For downhole alteration colors the circles are located at the center depth for each alteration interval. See Figure F33 for an explanation of lithology and stratigraphic units.

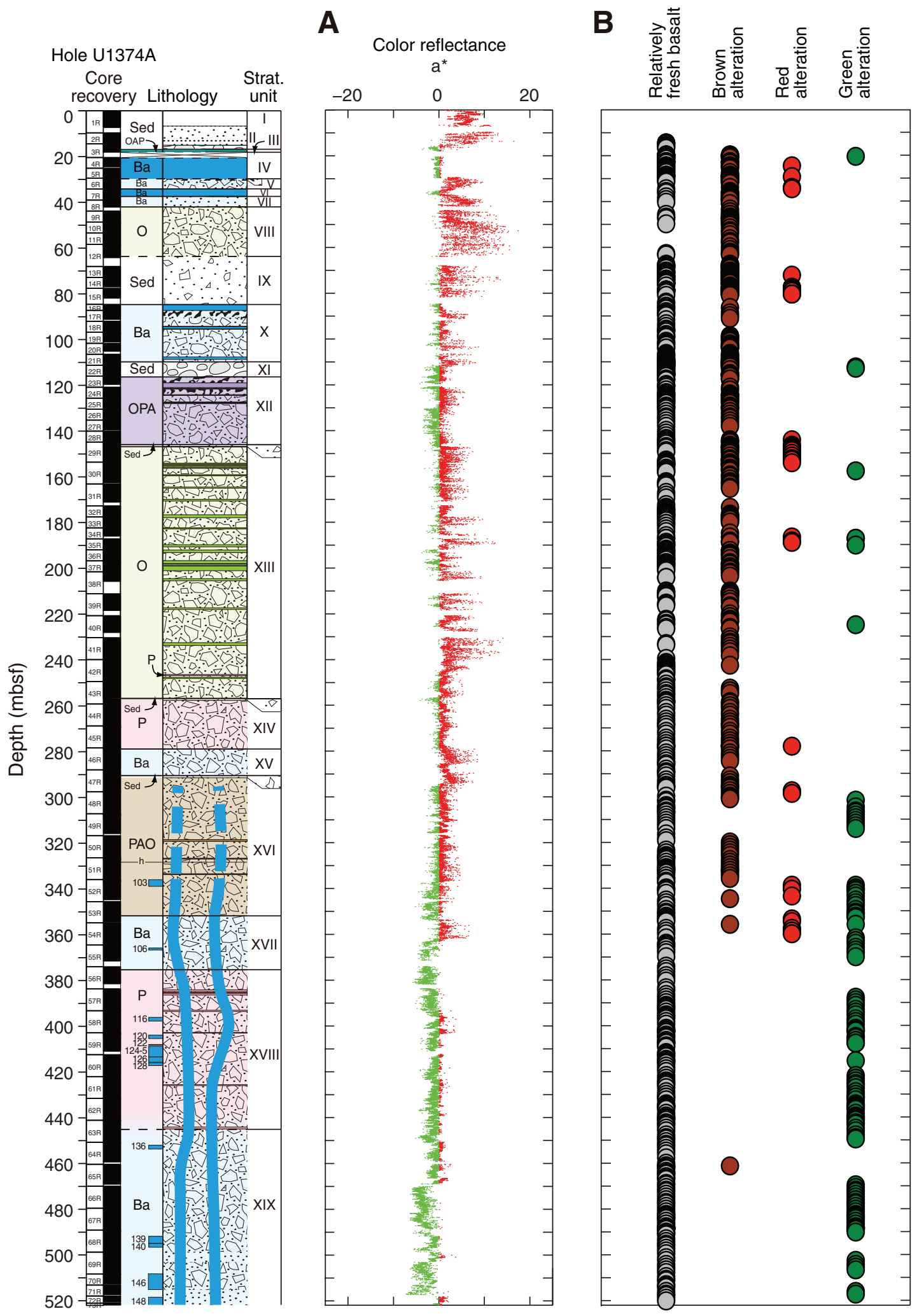


Figure F38. Downhole variation of (A) Mg\#, (B) Ba/Y, and (C) Zr/Ti in Site U1374 igneous rocks. Dashed lines $=$ stratigraphic unit boundaries. See Figure F33 for explanation of lithology and stratigraphic units. Note that Site U1374 major element data are normalized to $100 \mathrm{wt} \%$ totals.

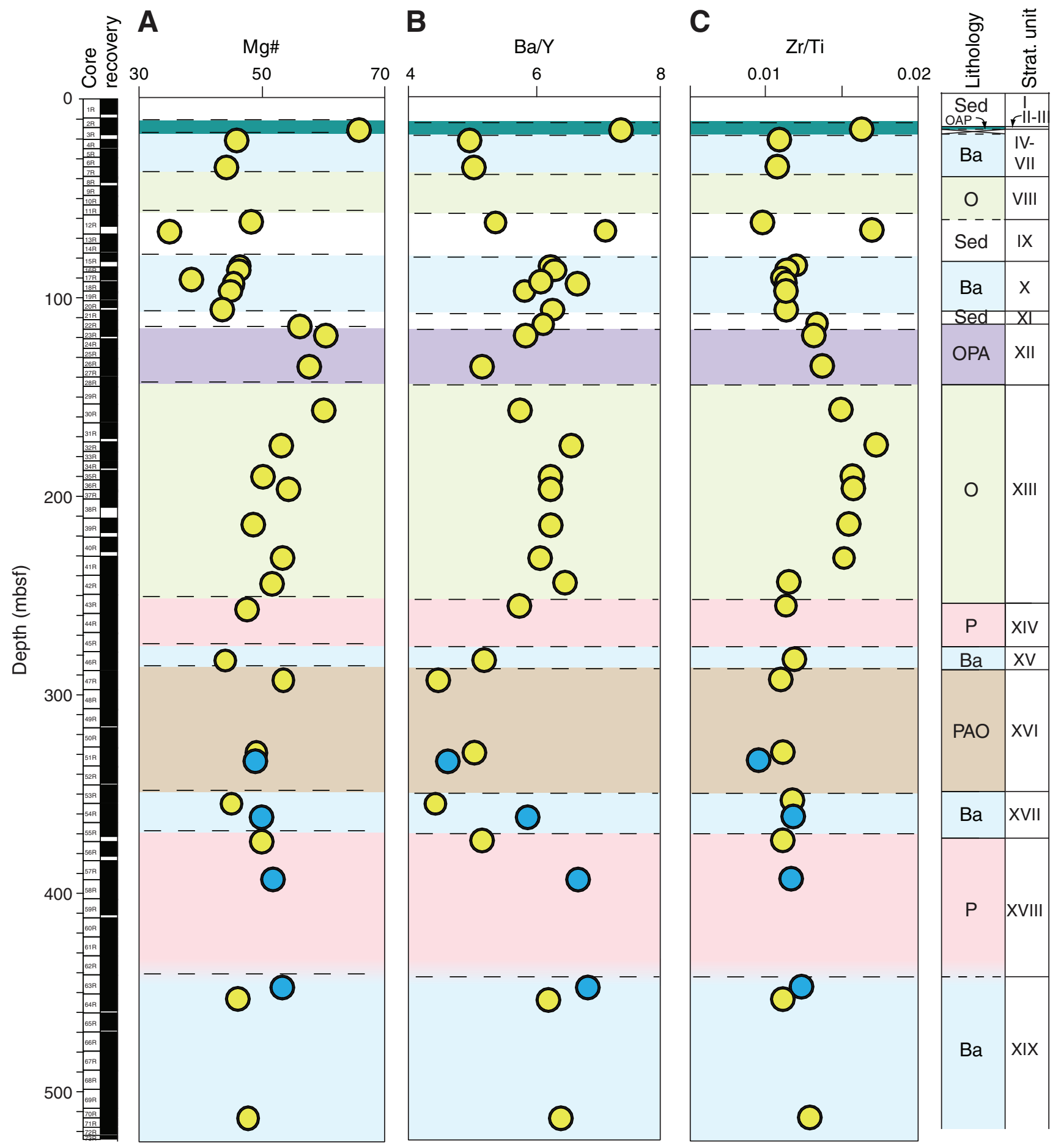


Figure F39. $\mathrm{TiO}_{2}$ vs. (A) $\mathrm{Sr}$ and (B) Y. Note that Site U1374 major element data are normalized to 100 wt $\%$ totals. Data for dredged samples from the Louisville Seamount Trail include only samples with LOI $<6$ wt $\%$. OJP $=$ Ontong Java Plateau, EPR = East Pacific Rise. See Figure F6 caption for references for data other than Site U1374.
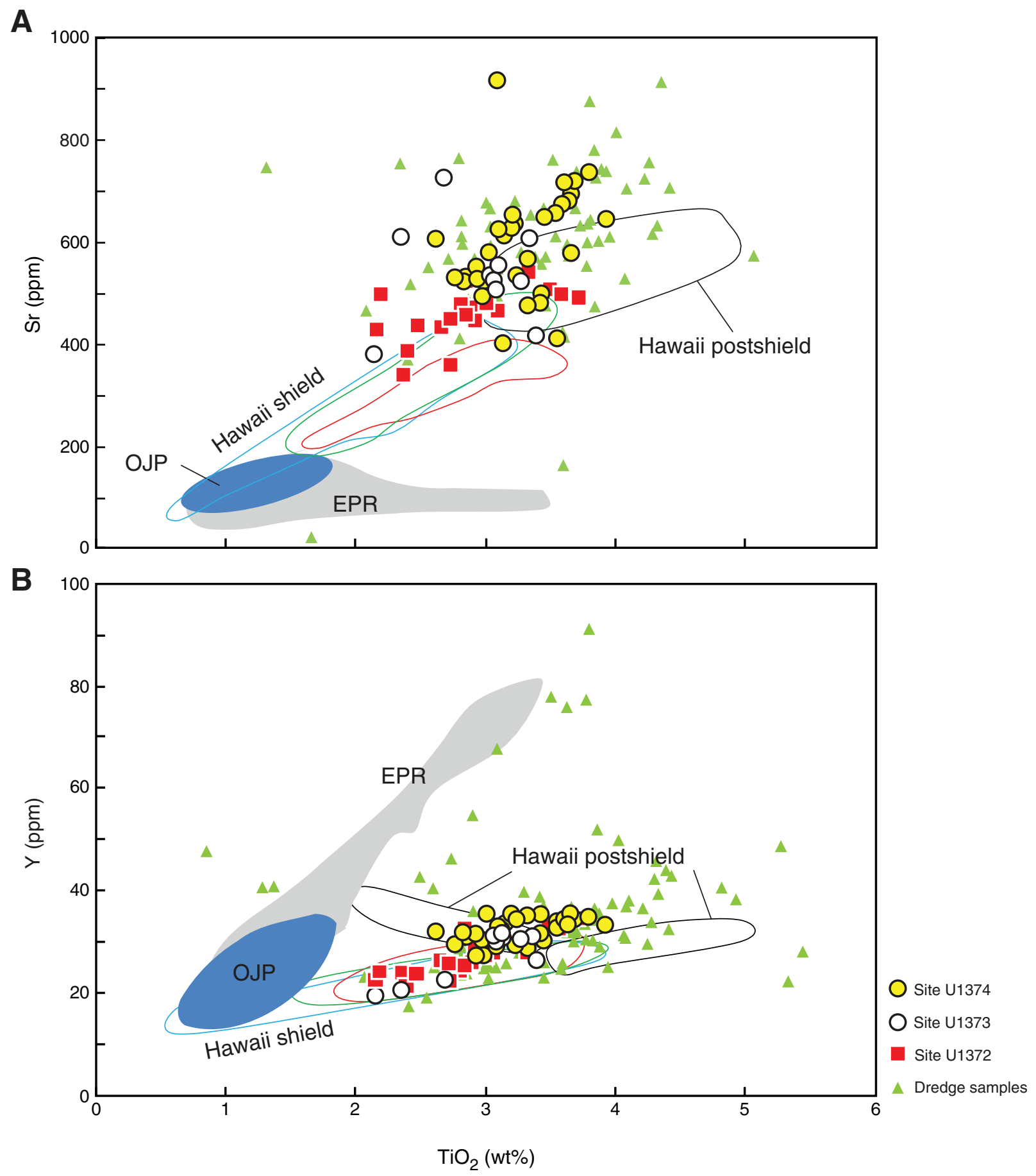
Figure F40. Downhole paleomagnetic data from archive-half cores, Site U1374. A. Core recovery and observed stratigraphy. See Figure F33 for an explanation of lithology and stratigraphic units. B. Downhole remanent intensity, showing natural remanent magnetization (purple) and principal component analysis (PCA) directions below (black) and above (gray) a threshold of PCA fitting quality. C. WRMSL magnetic susceptibility.

D. Median destructive field of the vector difference sum $\left(\mathrm{MDF}^{\prime}\right)$, shown only for intervals below threshold of PCA fitting quality.

A

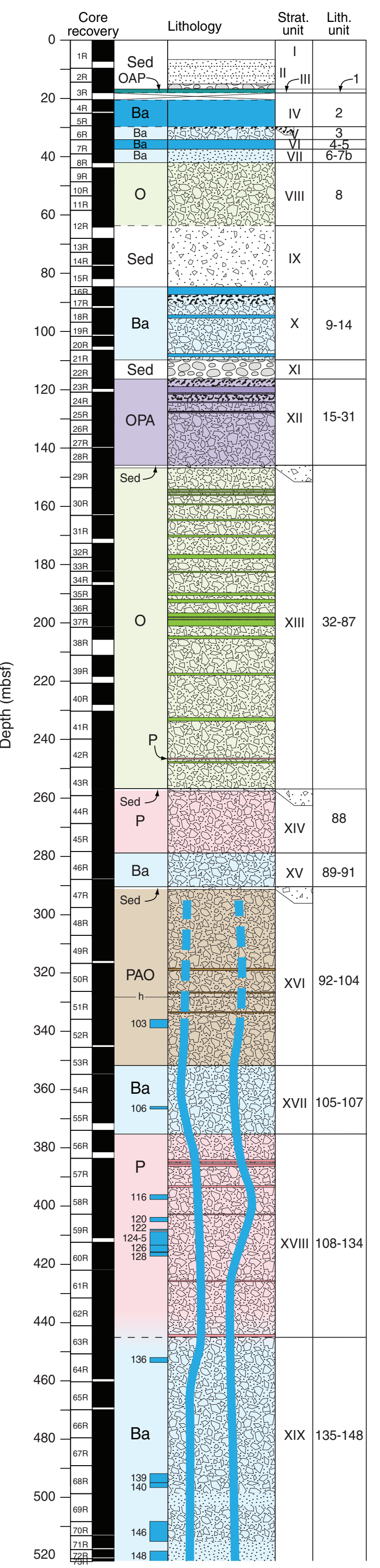

B Log intensity $(\mathrm{A} / \mathrm{m})$

C Log susceptibility

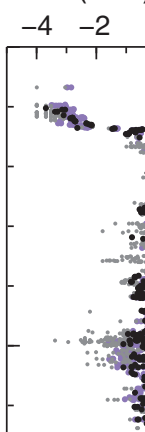

$\begin{array}{lll}1 & 2 & 3\end{array}$

D $\mathrm{MDF}^{\prime}$

$=$

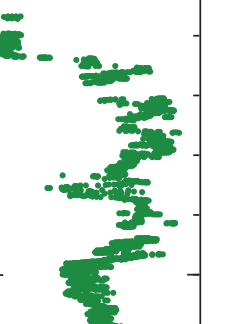

\begin{tabular}{l}
$40 \quad 80$ \\
$0 \quad 40$ \\
\hline \\
\hline
\end{tabular}

\&

.

E.

耧

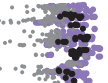

.

\%

-

$\frac{3}{3}$

to

3

?

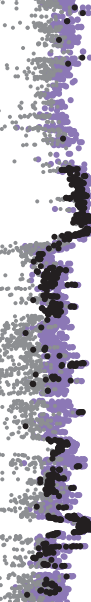

$\frac{3}{3}$

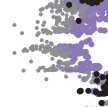

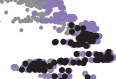

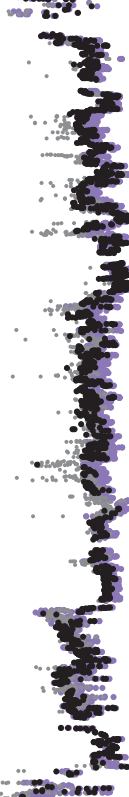

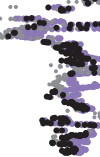

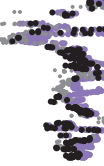


Figure F41. Example of remanent magnetization directions from AF demagnetization of archive half of Section 330-U1374A-59R-2. Directions were determined using principal component analysis (PCA). Dark blue = declinations for PCA directions with misfits below threshold of PCA fitting quality, light blue = declinations with misfits above threshold. Dark red = inclinations for PCA directions with misfits below threshold of PCA fitting quality, light red = inclinations with misfits above threshold. Open circles with error bars = piece-average directions, triangle = inclination from AF-demagnetized discrete sample, square = inclination from thermally demagnetized discrete sample. To avoid edge effects, data acquired within $4.5 \mathrm{~cm}$ of either piece end were filtered out.
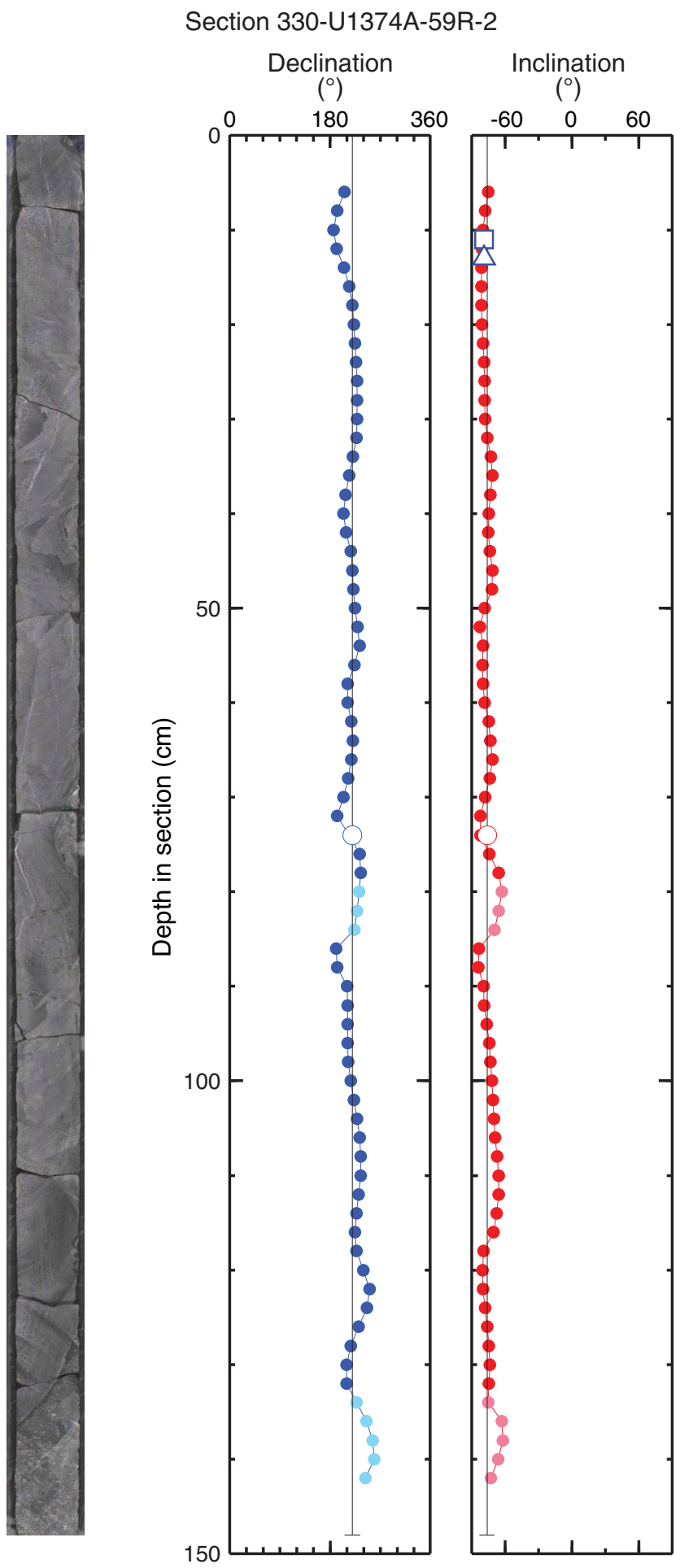
Figure F42. Representative Zijderveld plots for stepwise (A) alternating-field and (B-D) thermal demagnetization results of discrete samples. Solid and open circles indicate projections of vector endpoints onto the horizontal and vertical planes, respectively. Red arrows indicate direction derived from principal component analysis. $\mathrm{NRM}=$ natural remanent magnetization.

A

Sample 330-U1374A-21R-2, 55-57 cm Lava lobe

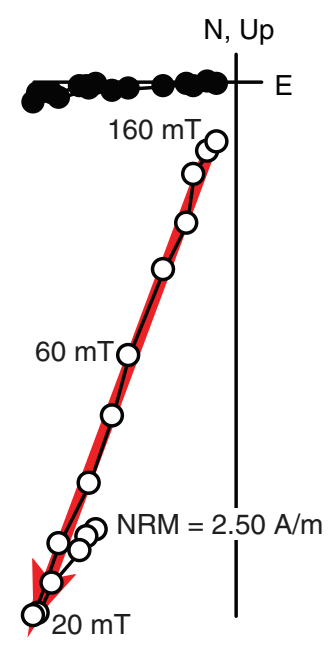

C

Sample 330-U1374A-58R-3, 124-126 cm Intrusive sheet

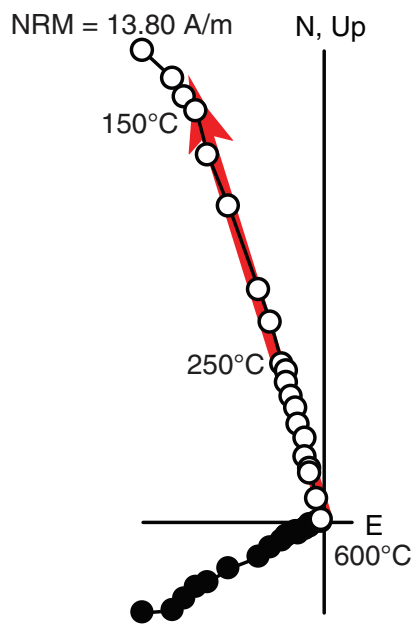

B Sample 330-U1374A-21R-2, 58-60 cm Lava lobe

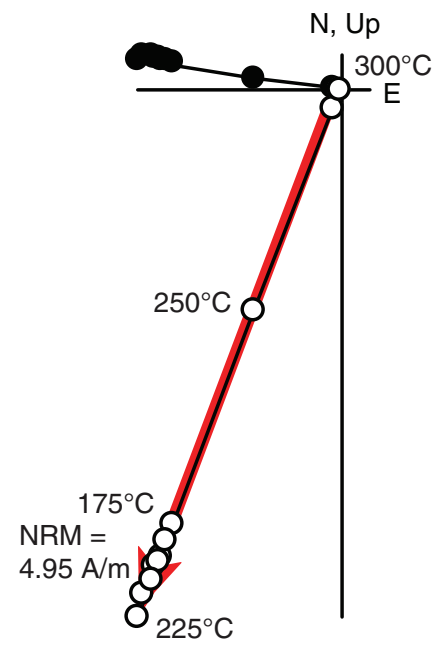

D Sample 330-U1374A-61R-2, 49-51 cm Volcaniclastic breccia

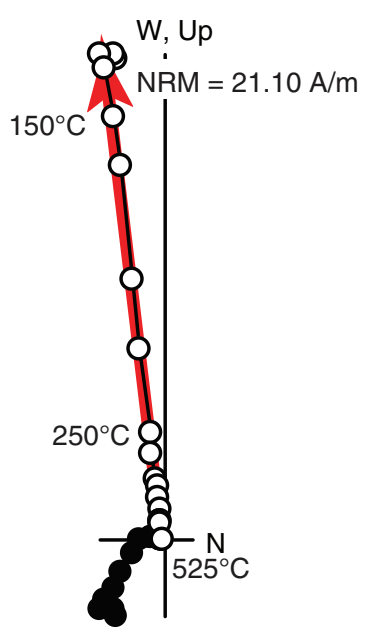


Figure F43. Plots of downhole logs and log unit divisions, Hole U1374A. A. Gamma ray (UBId = Ultrasonic Borehole Imager downlog, $\mathrm{TCm}=$ triple combo main pass) and caliper. B. Density (open circles = onboard moisture and density [MAD] measurements on discrete samples, plotted in mbsf). C. Resistivity (IMPH = medium induction phasor-processed resistivity, IDPH = deep induction phasor-processed resistivity).

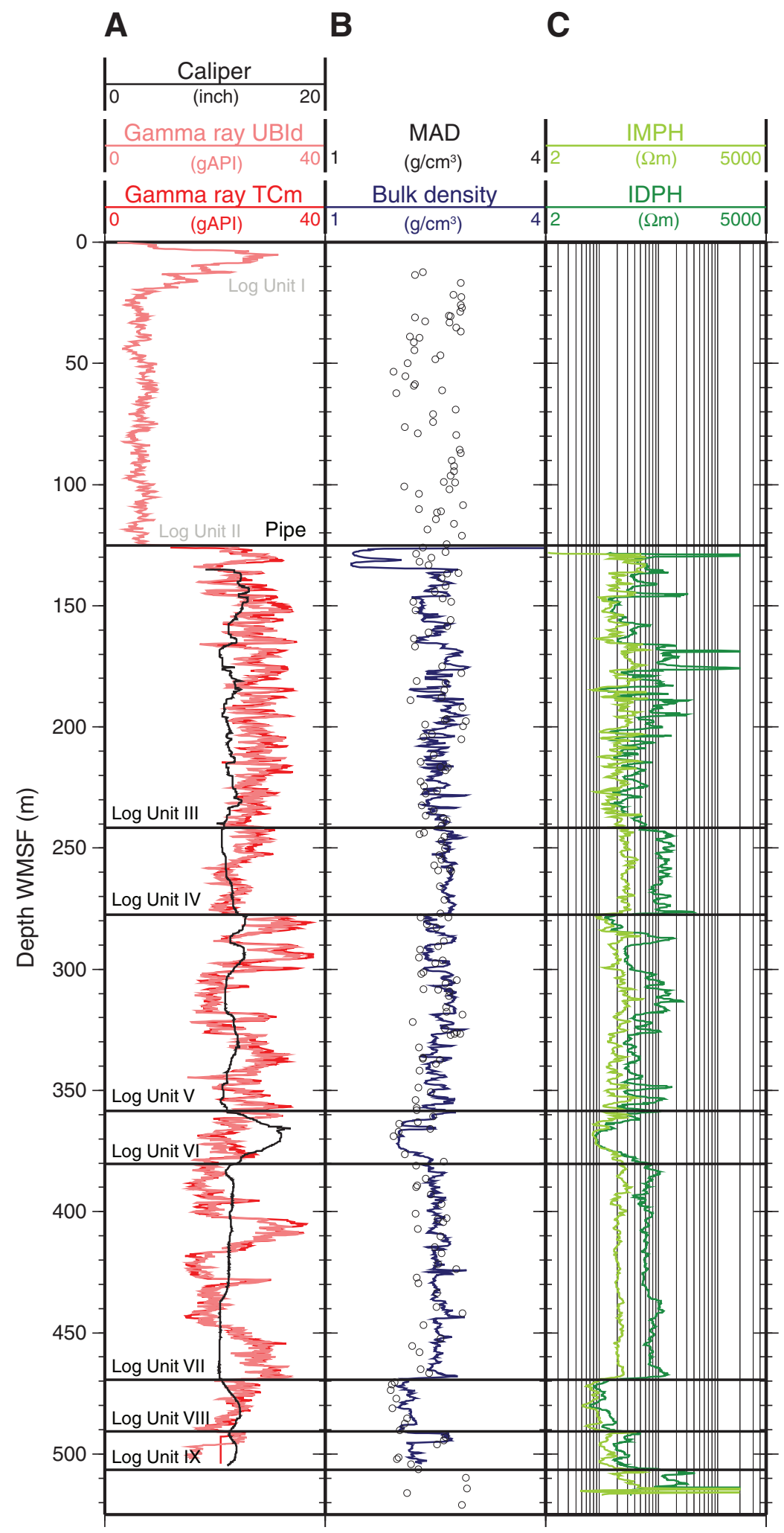


Figure F44. Comparison of raw magnetic field vertical-component data (not corrected for tool inclination) from Run 1 with the Göttingen Borehole Magnetometer (GBM) with lithology, Hole U1374A. See Figure F33 for explanation of stratigraphic units.

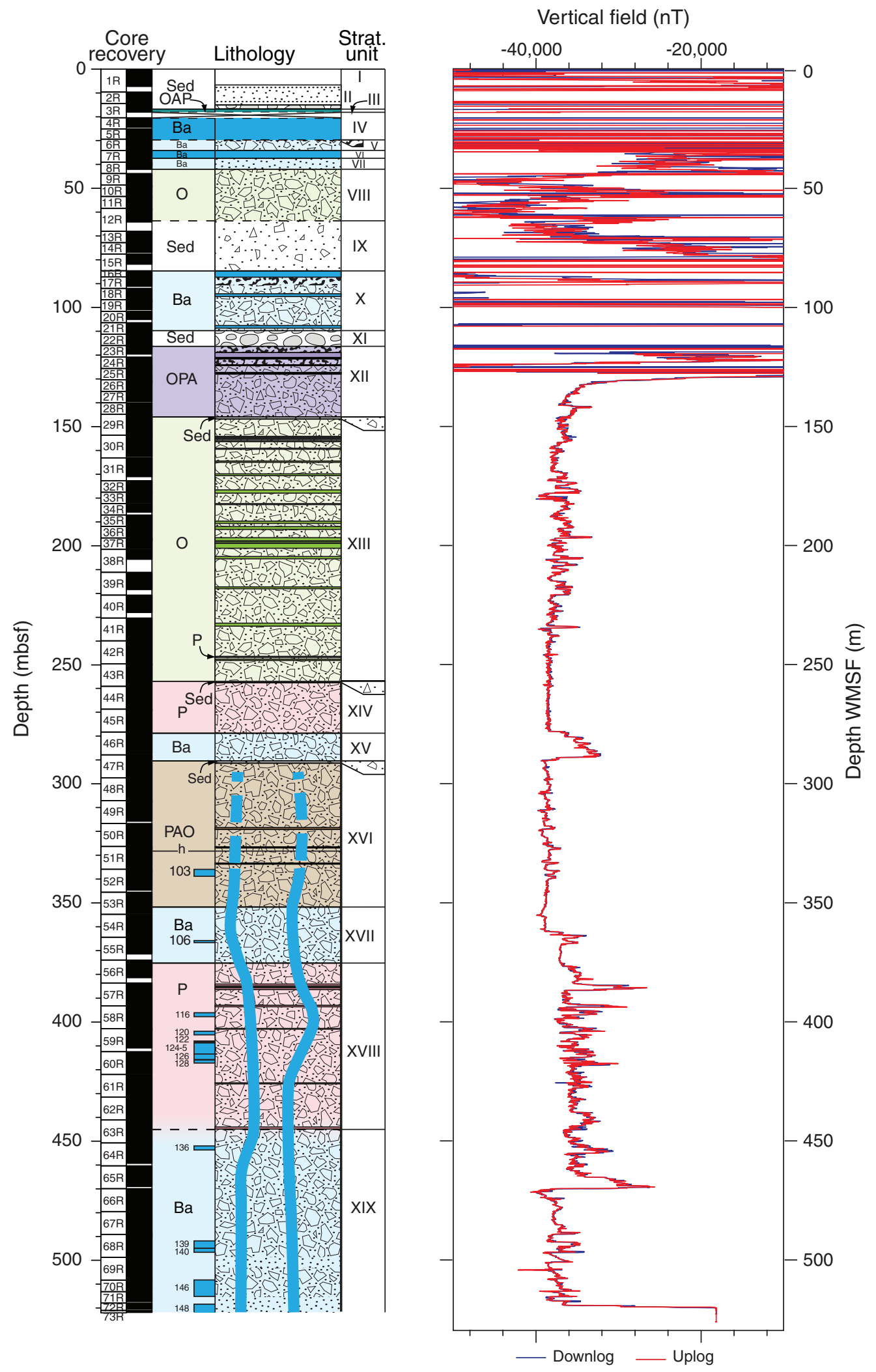


Figure F45. Detailed bathymetric map of Site U1375 on Achernar Guyot. GMT-generated bathymetric map is based on a combination of SIMRAD EM120 multibeam data collected during the AMAT02RR site survey expedition aboard the R/V Roger Revelle and global predicted bathymetry (v8.2) from Smith and Sandwell (1997). Dredge locations from previous cruises are indicated by open squares. Crossing multichannel seismic reflection lines collected during the AMAT02RR site survey are shown in blue (for details see Koppers et al., 2010). Map uses a linear projection (i.e., horizontal and vertical scales differ) based on WGS-84.

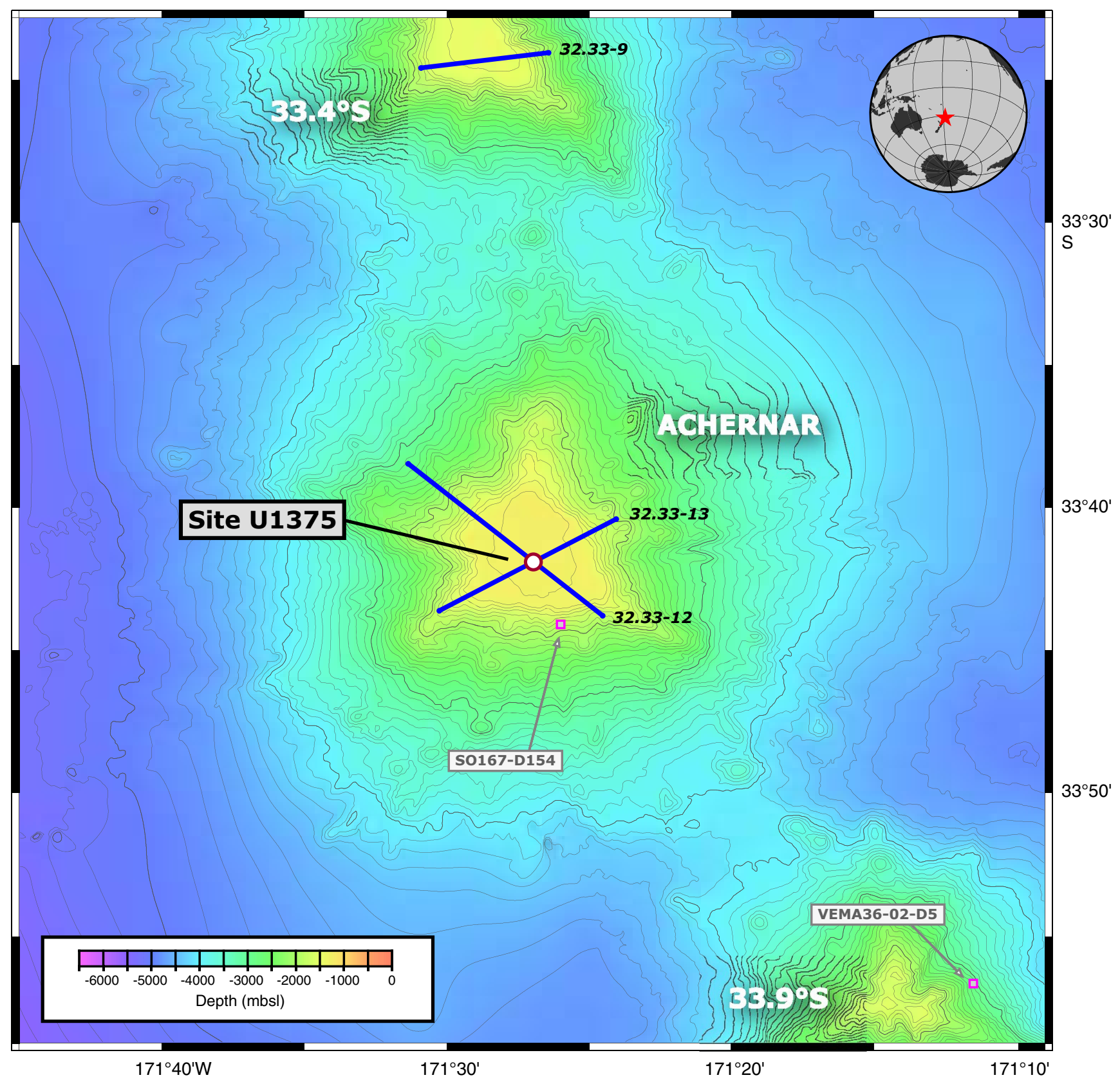


Figure F46. Close-up photographs of select representative lithologies, Hole U1375A. A. Multicolor basalt conglomerate from Subunit IIA (interval 330-U1375A-2R-1, 1-41 cm), topped by (1) ferromanganese encrustation. The interpebble and intercobble spaces are composed of foraminiferal limestone, finer grained volcaniclastic sediments, cement, and voids, with (2) bioturbations and (3) geopetal structures. This sediment is interpreted as a hemipelagic interval in the sedimentary cover of Achernar Guyot. B. Multicolor basalt breccia from Subunit IIB (interval 330-U1375A-2R-1, 79-119 cm), including (1) an erosional surface, (2) a basalt cobble with a jigsaw-fit texture including calcite cement in its upper border, and (3) sediment infills in some cracks. This subunit is interpreted as a debris flow deposit from the sedimentary cover.

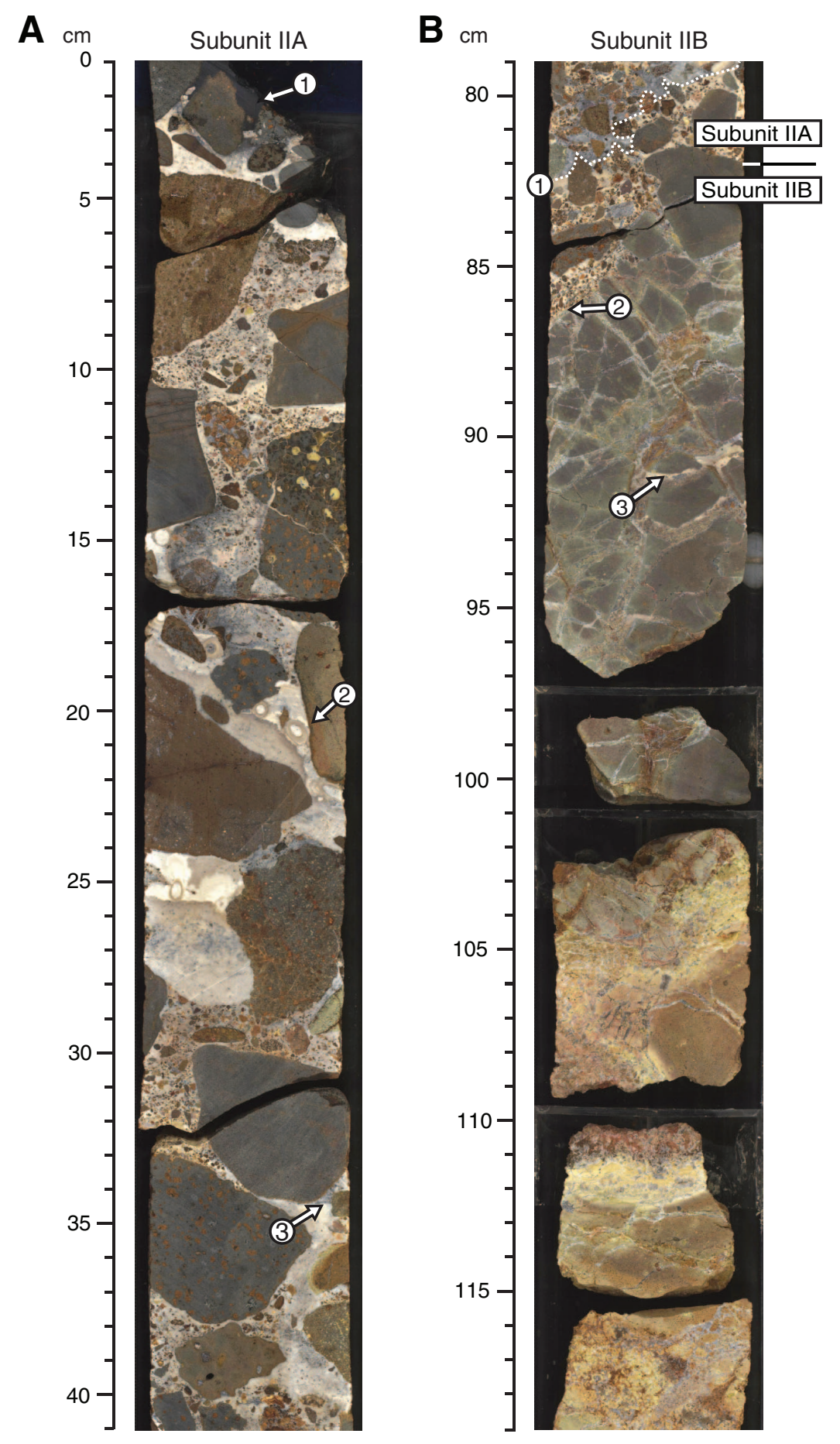


Figure F47. Thin section photomicrographs of micritic limestone, Site U1375. Arrows point toward top of core. A. Micritic limestone from Subunit IIA containing a few planktonic foraminifers (top) overlying volcaniclastic sandstone fragment (bottom) (Sample 330-U1375A-2R-1, 67-70 cm; Thin Section 225) (plane-polarized light). Volcanic glass in the volcaniclastic sandstone is cemented by calcite. B. Micritic limestone from Subunit IIA containing (1) benthic foraminiferal, (2) bryozoan, (3) echinoderm, and (4) planktonic foraminiferal fragments (Sample 330-U1375A-2R-1, 26-29 cm; Thin Section 224) (plane-polarized light). This highly fossiliferous limestone including foraminifers overlies a less fossiliferous one containing macrofossil and volcaniclastic fragments.
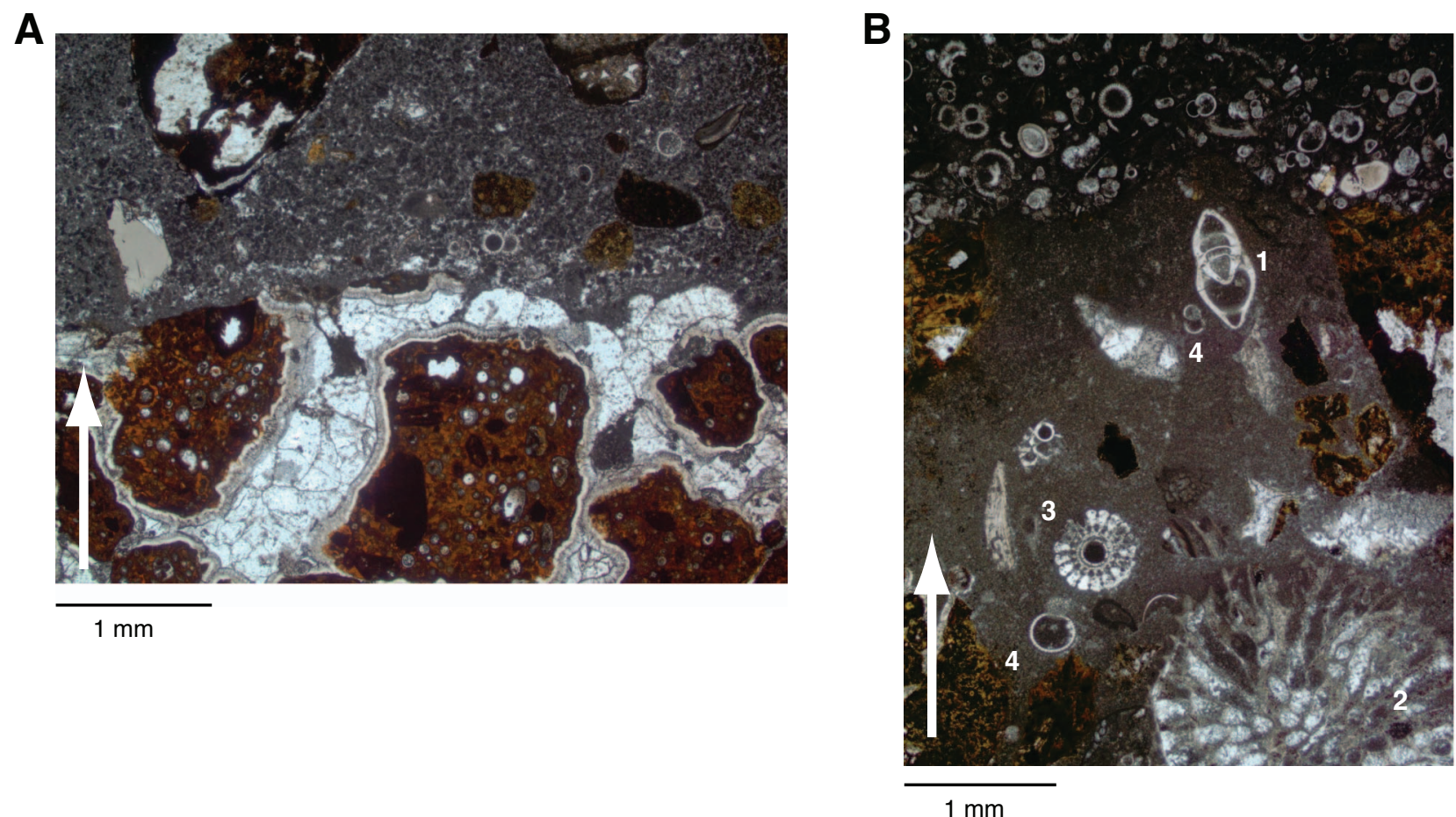
Figure F48. Thin section photomicrographs, Site U1375. A. Moderately olivine-augite-phyric microgabbro from Unit I (Sample 330-U1375B-1R-1, 1-3 cm; Thin Section 227) (with crossed polars). B. Close-up of moderately porphyritic intergranular holocrystalline texture (Sample 330-U1375B-1R-1, 56-57 cm; Thin Section 228) (with crossed polars). Groundmass texture is characterized by tabular plagioclase with anhedral crystals of augite in the interstices.

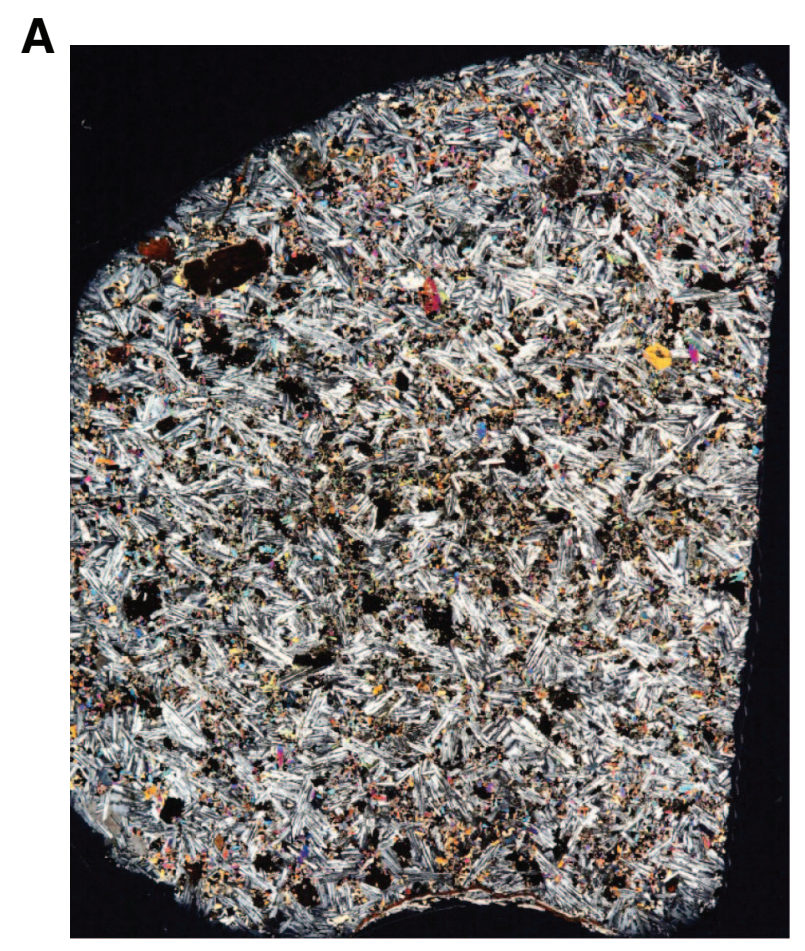

B

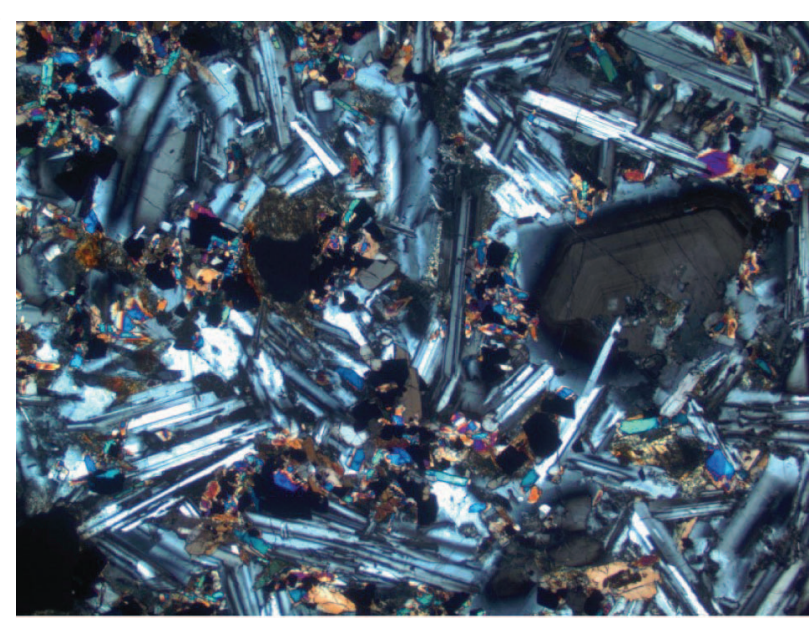

$1 \mathrm{~mm}$

$10 \mathrm{~mm}$ 
Figure F49. Detailed bathymetric map of Site U1376 on Burton Guyot. GMT-generated bathymetric map is based on a combination of SIMRAD EM120 multibeam data collected during the AMAT02RR site survey expedition aboard the R/V Roger Revelle and global predicted bathymetry (v8.2) from Smith and Sandwell (1997). Crossing multichannel seismic reflection lines collected during the AMAT02RR site survey are shown in blue (for details see Koppers et al., 2010). Map uses a linear projection (i.e., horizontal and vertical scales differ) based on WGS-84.

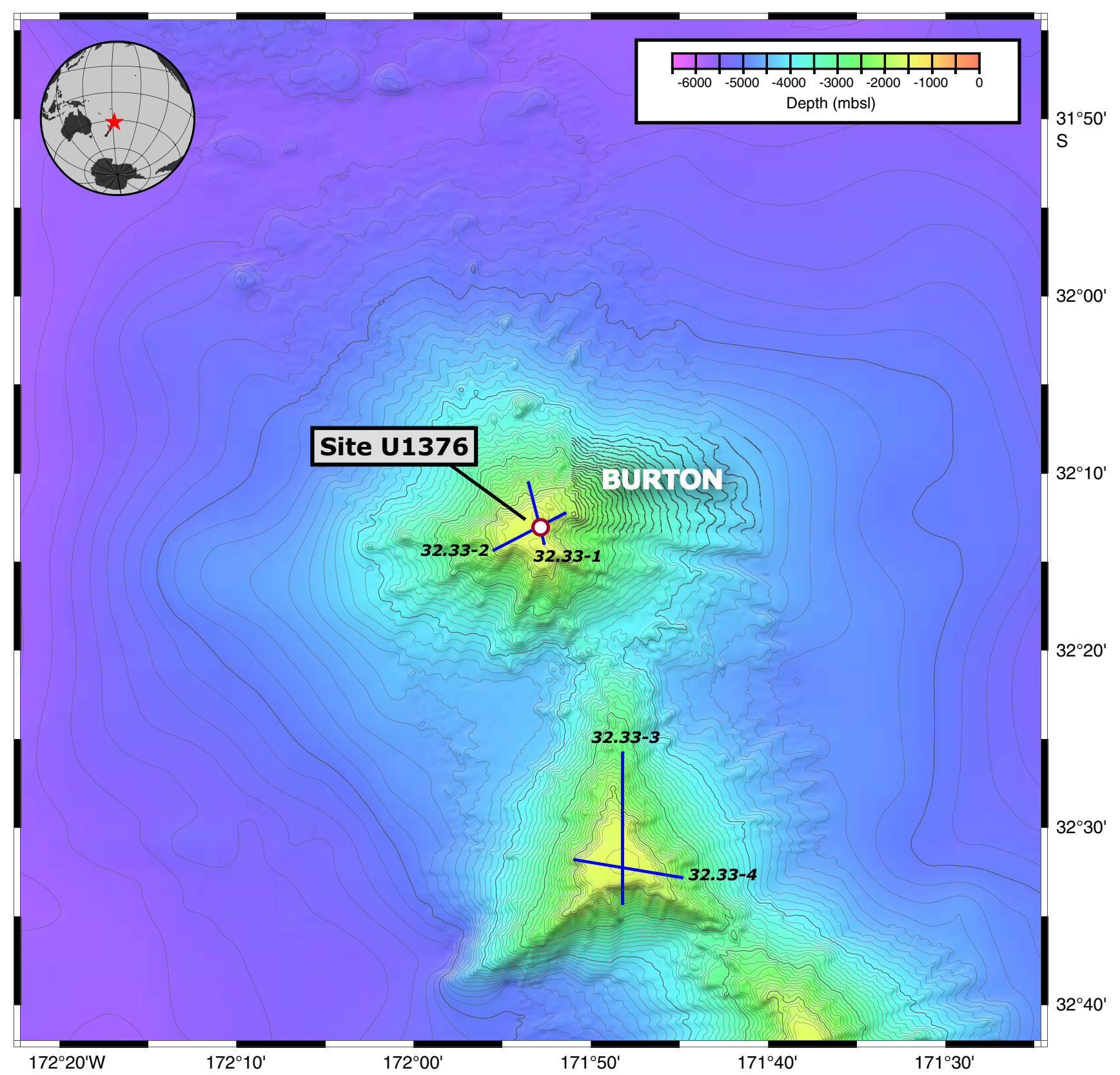


Figure F50. Stratigraphic summary, Hole U1376A. A. Sedimentary sequence. B. Lithology and volcanological features of igneous sequence.
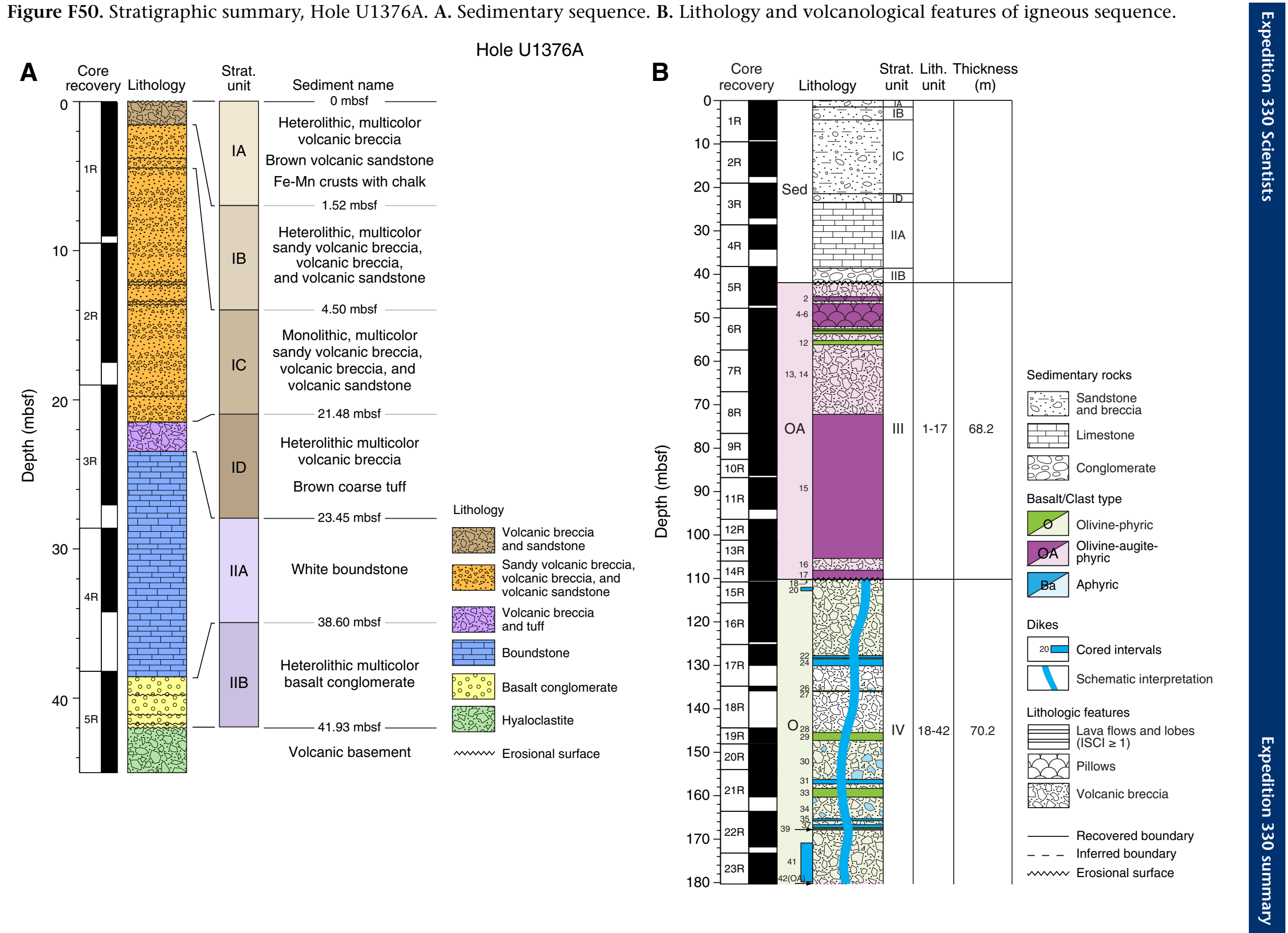
Figure F51. Scanned core images of select representative lithologies, Hole U1376A. A. Heterolithic layered multicolor basalt breccia (top and bottom) and heterolithic bioturbated volcanic sandstone (middle) from Subunit IA (interval 330-U1376A-1R-1, 15-55 cm). Arrows show (1) ferromanganese crusts and (2) nannofossil foraminiferal chalk in a ferromanganese crust. Subunit IA likely consists of several hyperconcentrated flow deposits (layered breccia) and turbidites (bioturbated sandstone) emplaced in a pelagic or hemipelagic environment. B. Monolithic bioturbated brown coarse tuff (top and bottom) and heterolithic multicolor volcanic sandstone (center) from Subunit ID (interval 330-U1376A-3R-4, 1-41 cm). Compaction features observed were (1) loadcasts and (2) a small synsedimentary fault. Subunit ID likely consists of turbidites and coarse tuff deposited in a hemipelagic or pelagic environment. C. Algal boundstone with a branching growth form of alga from Subunit IIA interpreted as an algal reef (interval 330-U1376A-3R-5, 10-29 cm). D. Basalt conglomerate with shallowmarine bioclasts from Subunit IIB showing erosional contacts in (1) basalt conglomerate and (2) underlying volcanic basement from Unit III (interval 330-U1376A-5R-3, 106-125 cm). E. Volcanic breccia composed of angular basalt clasts cemented with calcite from Subunit IC (interval 330-U1376A-1R-4, 37-49 cm; see also Fig. F53D). F. Hyaloclastite breccia from lithologic Unit 21 in stratigraphic Unit IV (interval 330-U1376A-16R$4,45-57 \mathrm{~cm}$ ). The yellowish-gray color in the clasts indicates the presence of fresh glass. G. Scanned core image (left) and interpretation (right) of aphyric dike margin from lithologic Unit 20 (interval 330-U1376A-15R-2A, $22-95 \mathrm{~cm}$ ). Rows of dark blue dots = vesicle trains. (Figure shown on next page.) 

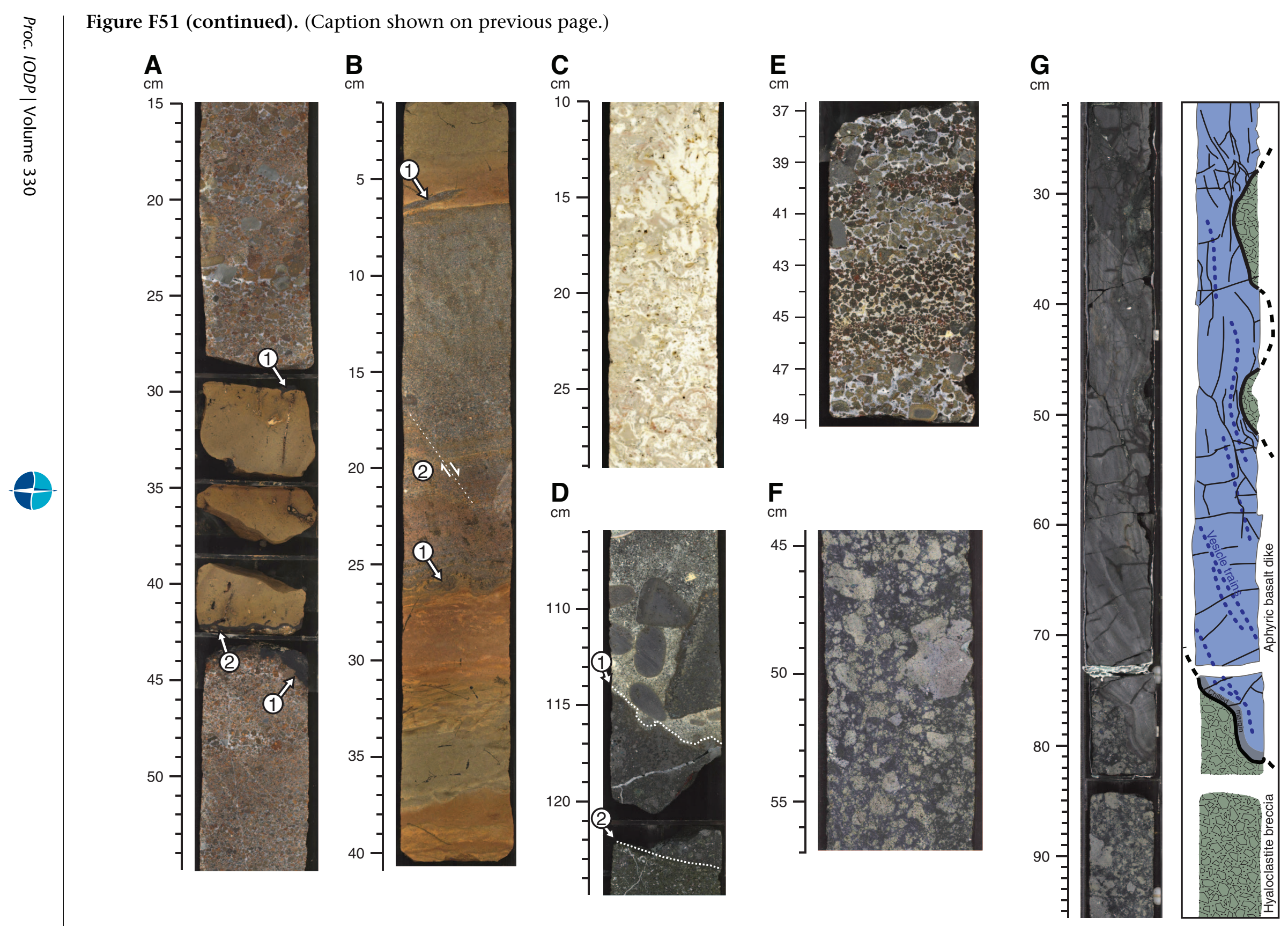
Figure F52. Thin section photomicrographs of sedimentary rocks, Site U1376. A. Volcanic tuff from Subunit ID with shards of fresh volcanic glass (Sample 330-U1376A-3R-3, 113-117 cm; Thin Section 238) (planepolarized light). B. Basalt conglomerate from Subunit IIB with (1) dogtooth cement and (2) geopetal structure defined by vadose silt and sparry calcite cement (Sample 330-U1376A-5R-1, 65-67 cm; Thin Section 244) (plane-polarized light). Cement and structure are indicative of a vadose cementation environment. Arrow points toward top.

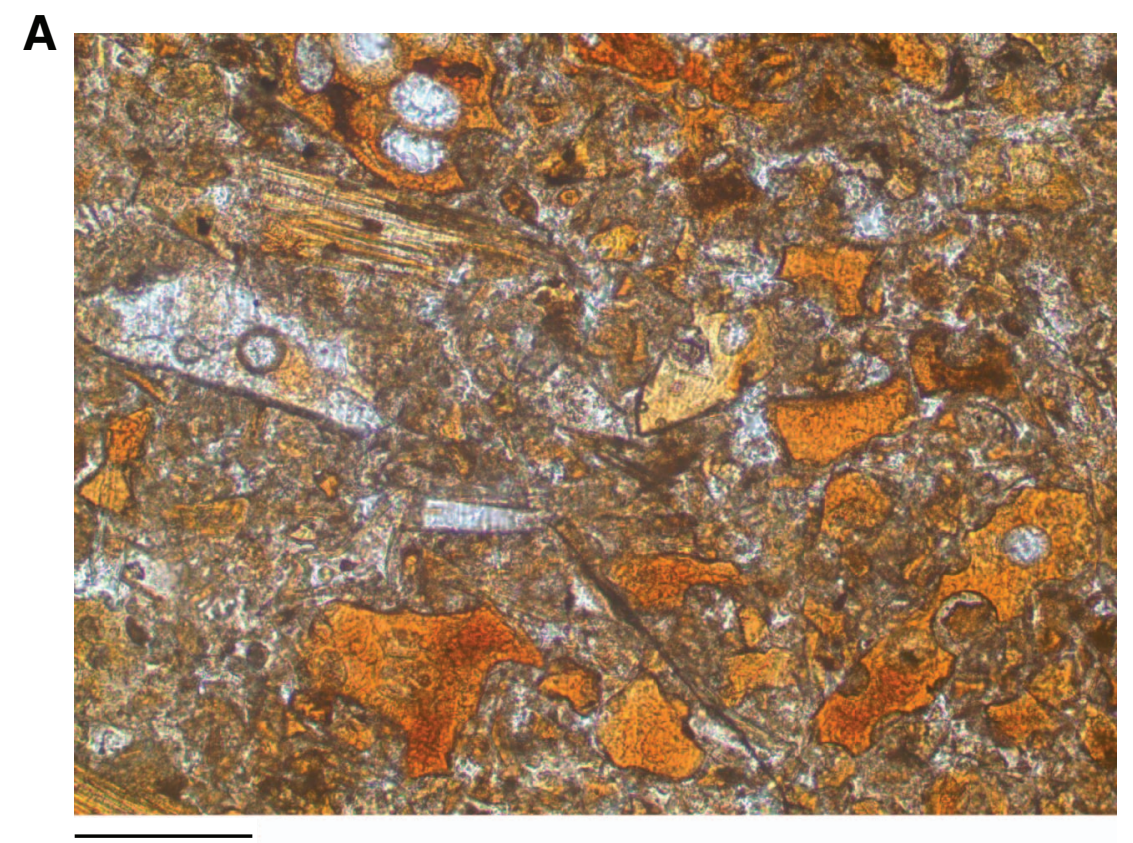

$0.1 \mathrm{~mm}$

B

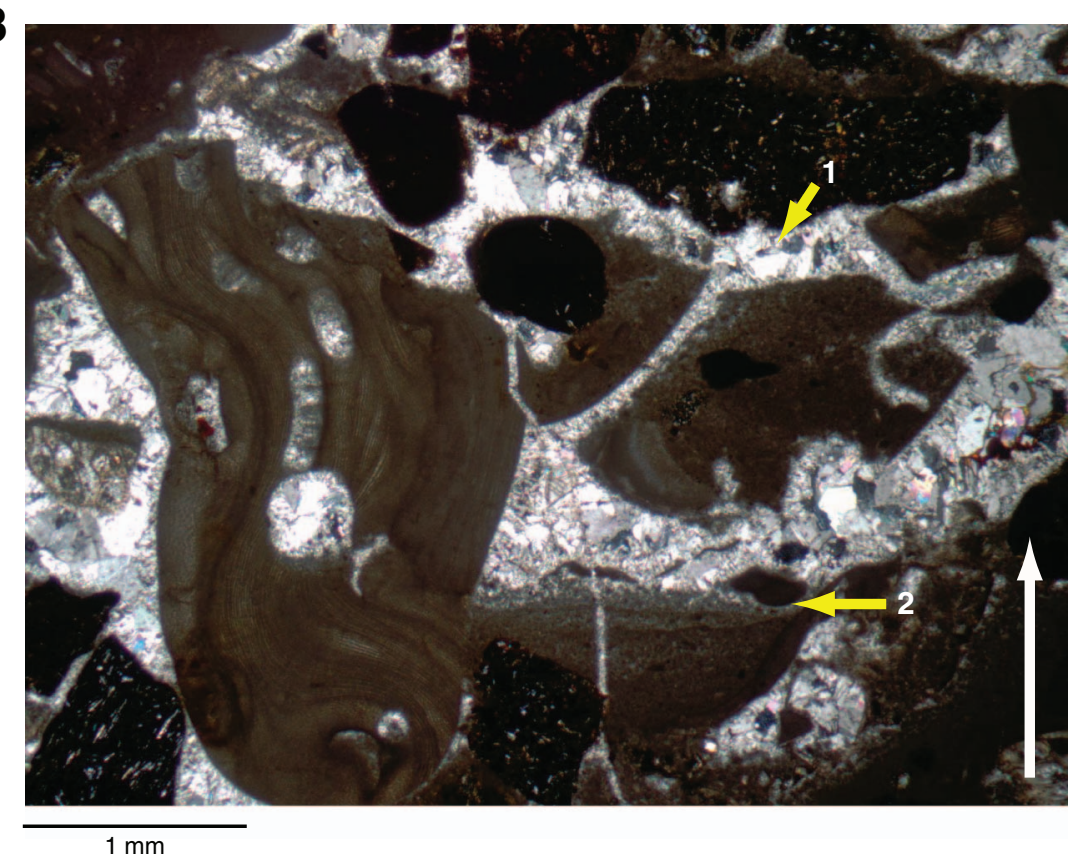


Figure F53. Thin section photomicrographs of basalt, Site U1376. Highly olivine-augite-phyric basalt from lithologic Unit 15 (A) under plane-polarized light and (B) with crossed polars (Sample 330-U1376A-8R-6, 136-140 $\mathrm{cm}$; Thin Section 255). C. Hyaloclastite breccia from lithologic Unit 21 showing fresh basaltic glass shards with curved edges (Sample 330-U1376A-17R-1, 140-143 cm; Thin Section 262) (plane-polarized light). Homogeneity of the glass suggests fragments quenched very rapidly, and shape of shards suggests they are bubble-walled fragments. Voids between glass shards are unfilled. Darkening of glass around shard edges is due to numerous minute tubes formed by microorganisms. D. Orthopyroxene xenocryst surrounded by reaction corona composed of tiny crystals of clinopyroxene (Sample 330-U1376A-1R-4, 39-42 cm; Thin Section 234) (plane-polarized light). See Figure F51E for scanned image of archive-half interval shown here. (Figure shown on next page.) 
Figure F53 (continued). (Caption shown on previous page.)

A

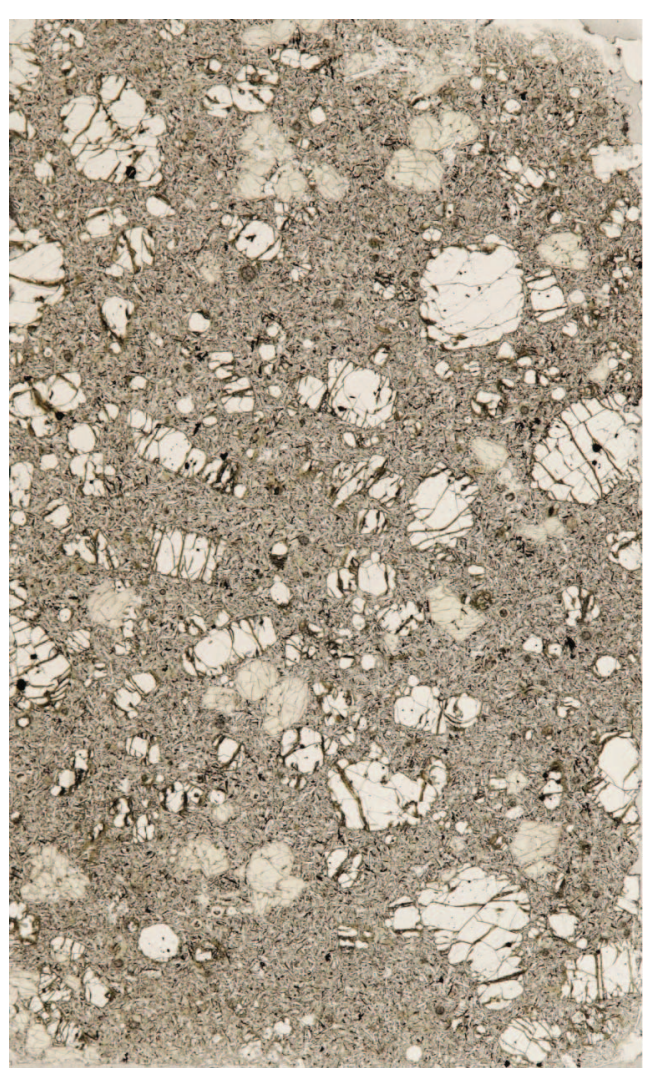

$10 \mathrm{~mm}$

C

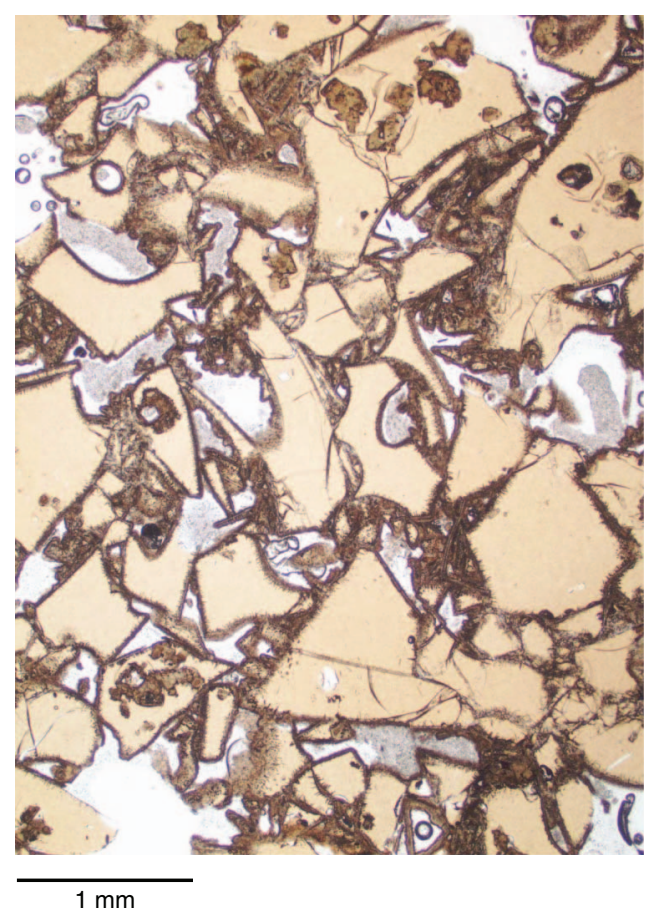

B

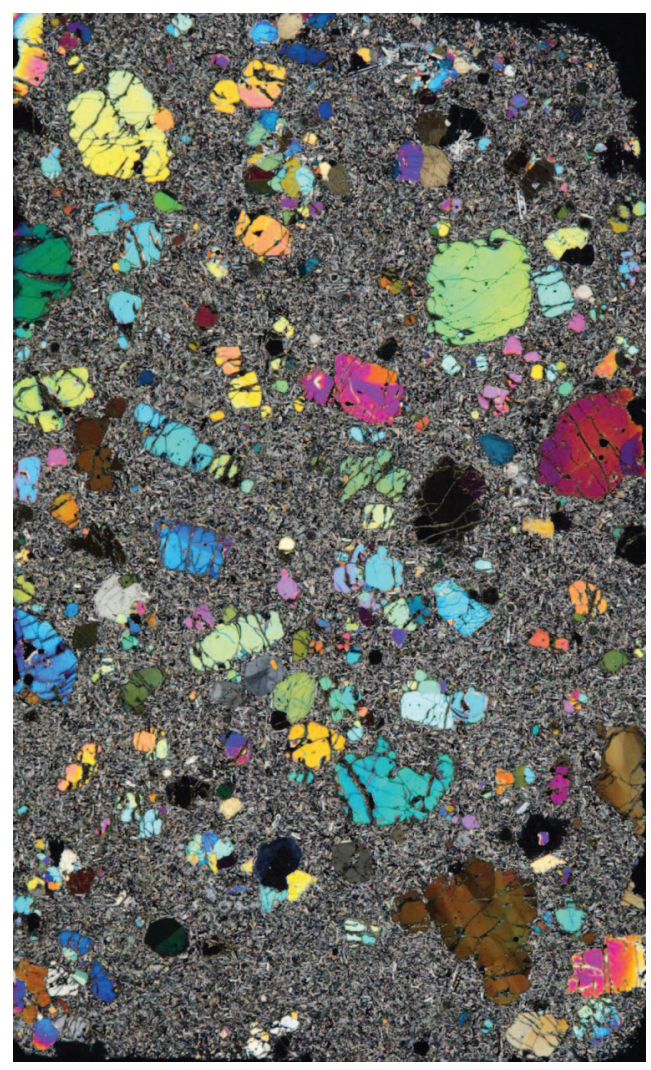

$10 \mathrm{~mm}$

D

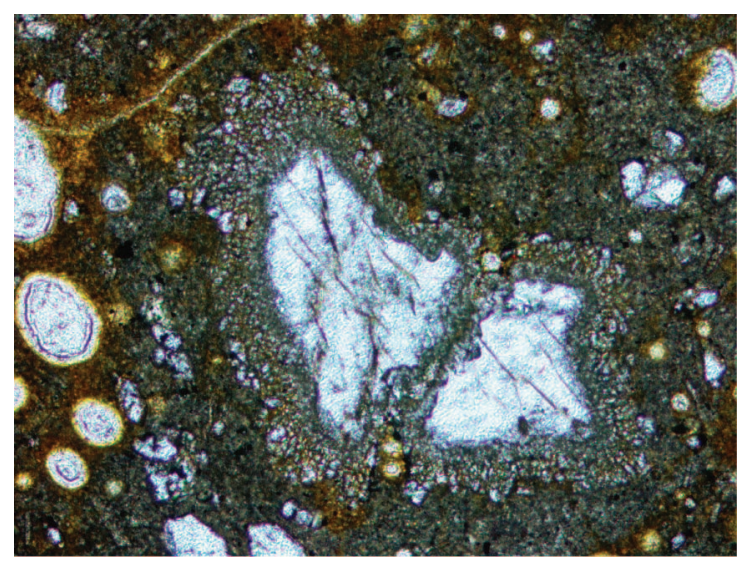

$0.5 \mathrm{~mm}$ 
Figure F54. Downhole variation of (A) color reflectance parameter $\mathrm{a}^{*}$ and (B) alteration color, Hole U1376A. Values of $\mathrm{a}^{*}$ represent relative color position between red (positive) and green (negative). For downhole alteration colors the circles are located at the center depth for each alteration interval. See Figure F50 for explanation of lithology and stratigraphic units.

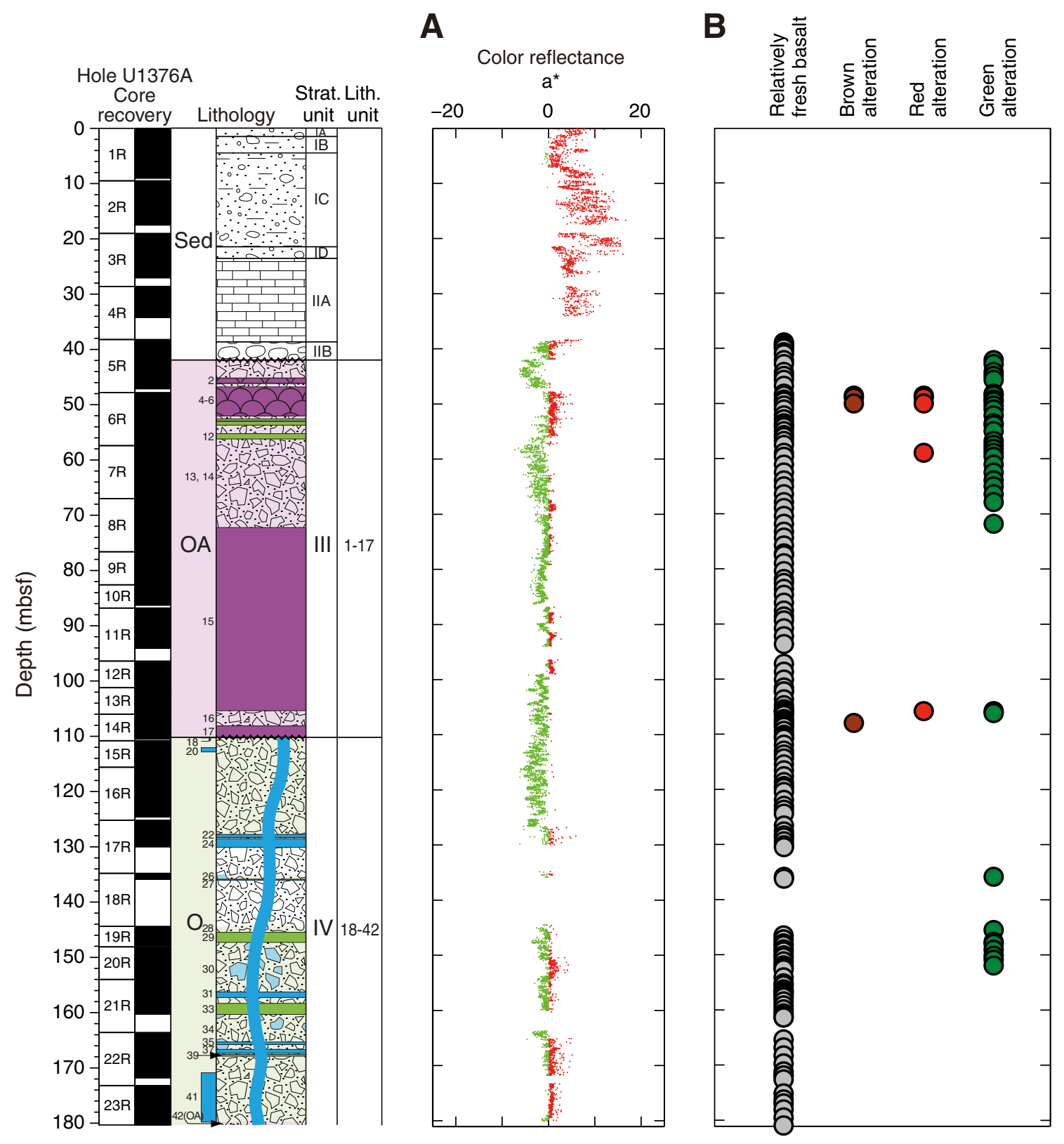


Figure F55. Downhole variation of (A) Mg\#, (B) Zr/Y, and (C) Ba/Y in Site U1376 igneous rocks. Dashed lines = stratigraphic unit boundaries. See Figure F50 for explanation of lithology and stratigraphic units. Note that Site U1376 major element data are normalized to $100 \mathrm{wt} \%$ totals.

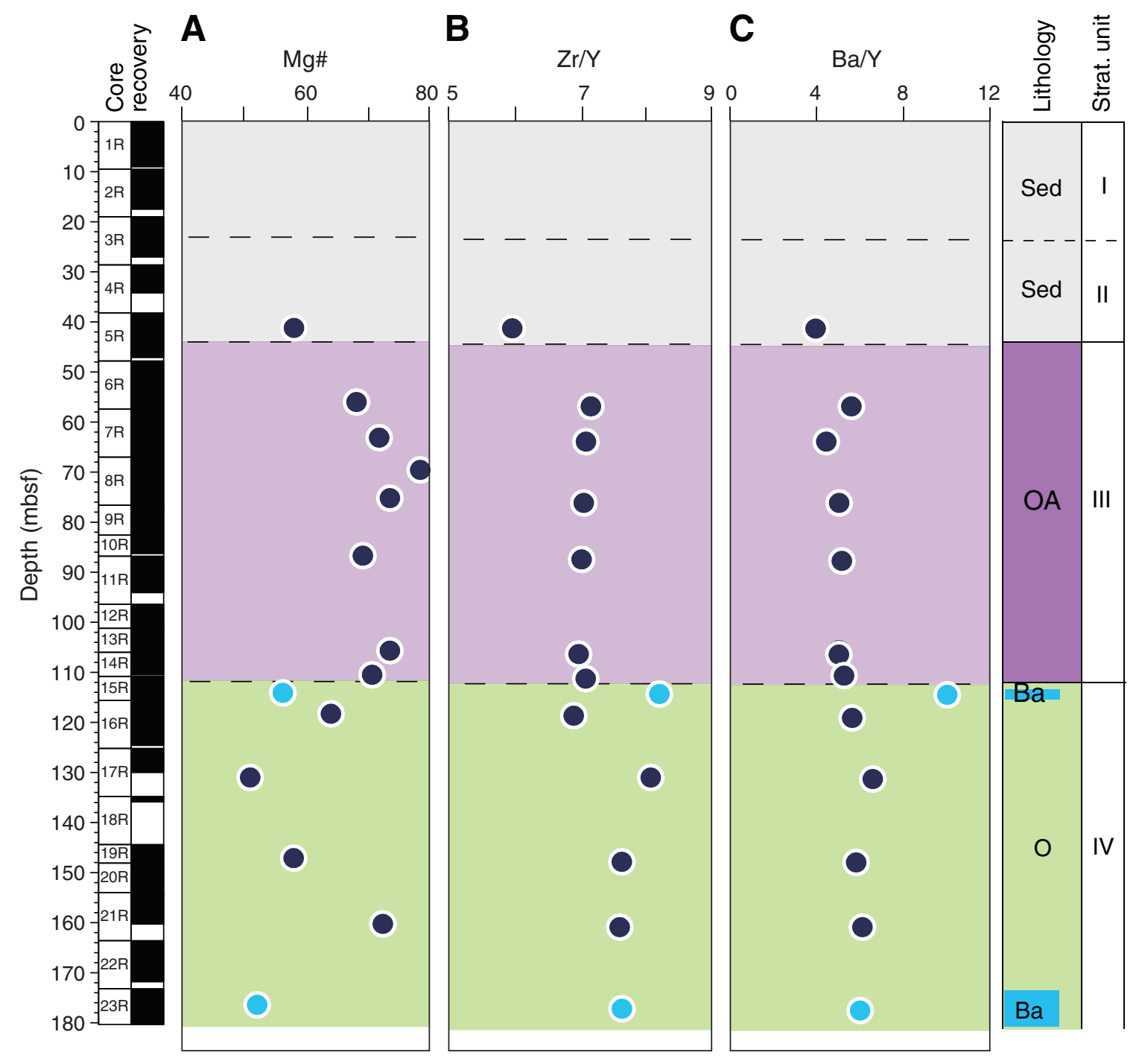


Figure F56. $\mathrm{TiO}_{2}$ vs. (A) Sr and (B) Y. Note that Site U1376 major element data are normalized to $100 \mathrm{wt} \%$ totals. Data for dredged samples from Louisville Seamount Trail include only samples with LOI $<6 \mathrm{wt} \%$. OJP = Ontong Java Plateau, EPR = East Pacific Rise. See Figure F6 caption for references for data other than Site U1376.
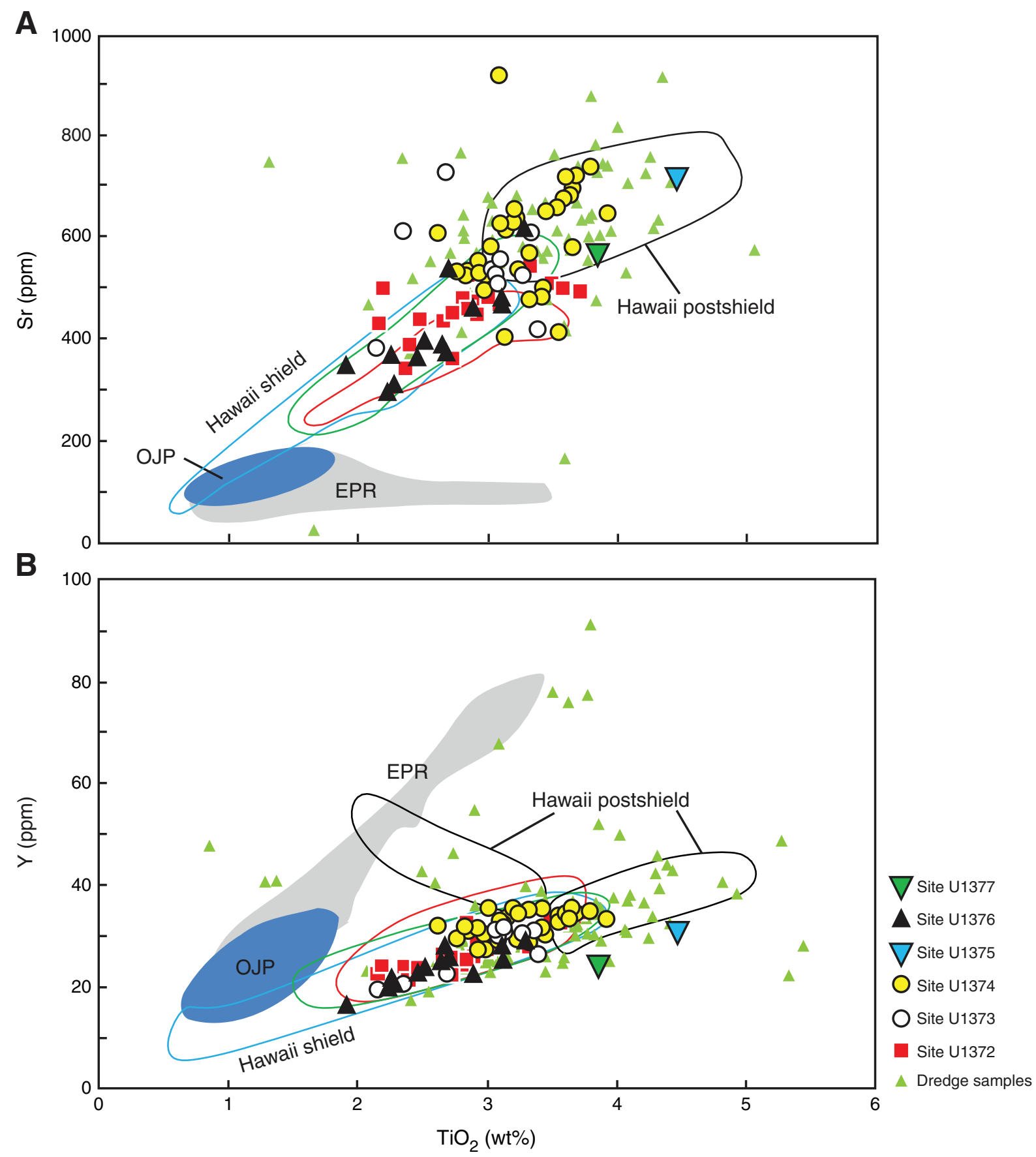
Figure F57. Downhole paleomagnetic data from archive-half cores, Site U1376. A. Core recovery and observed stratigraphy. See Figure F50 for explanation of lithology and stratigraphic units. B. Downhole remanent intensity, showing natural remanent magnetization (purple) and principal component analysis (PCA) directions below (black) and above (gray) a threshold of PCA fitting quality. C. WRMSL magnetic susceptibility. D. Median destructive field of the vector difference sum $\left(\mathrm{MDF}^{\prime}\right)$, shown only for intervals below threshold of PCA fitting quality.

A

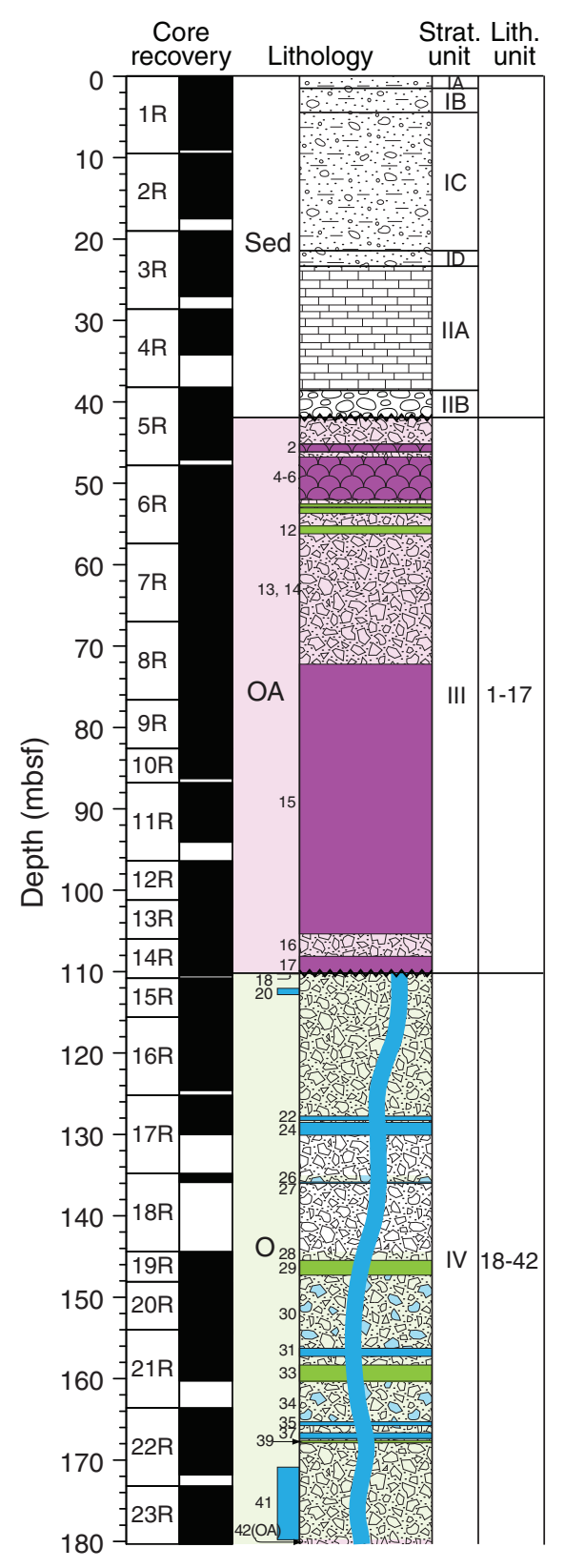

B Log intensity

$(\mathrm{A} / \mathrm{m})$

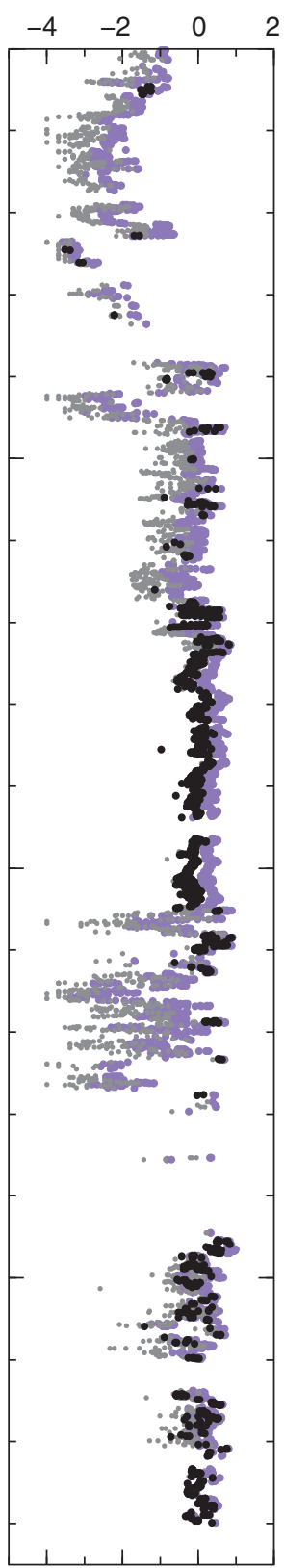

C Log susceptibility

$\left(10^{-5} \mathrm{SI}\right)$

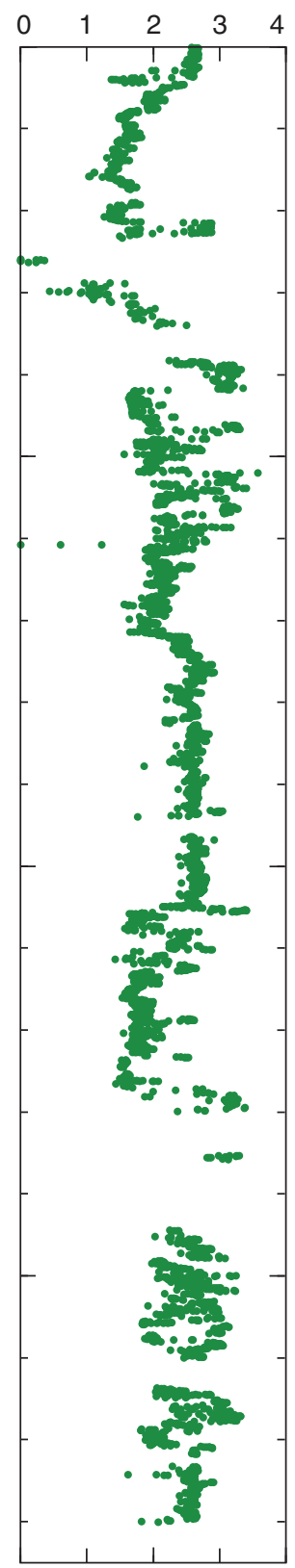

D $\mathrm{MDF}^{\prime}$

(mT)

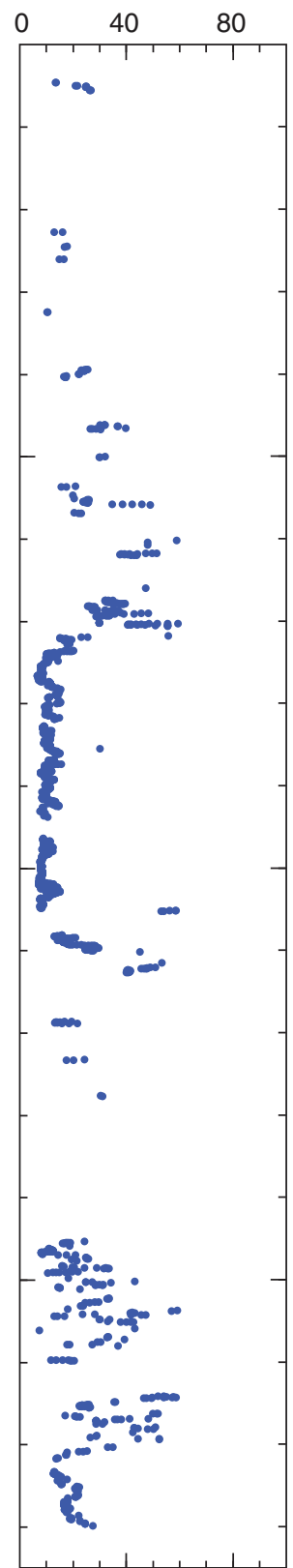


Figure F58. Example of remanent magnetization directions from AF demagnetization of archive half of Section 330-U1376A-12R-4. Directions were determined using principal component analysis (PCA). All PCA directions for this section have misfits below the threshold of PCA fitting quality. Open circles with error bars = pieceaverage directions, triangle = inclination from AF-demagnetized discrete sample. To avoid edge effects, data acquired within $4.5 \mathrm{~cm}$ of either piece end were filtered out.

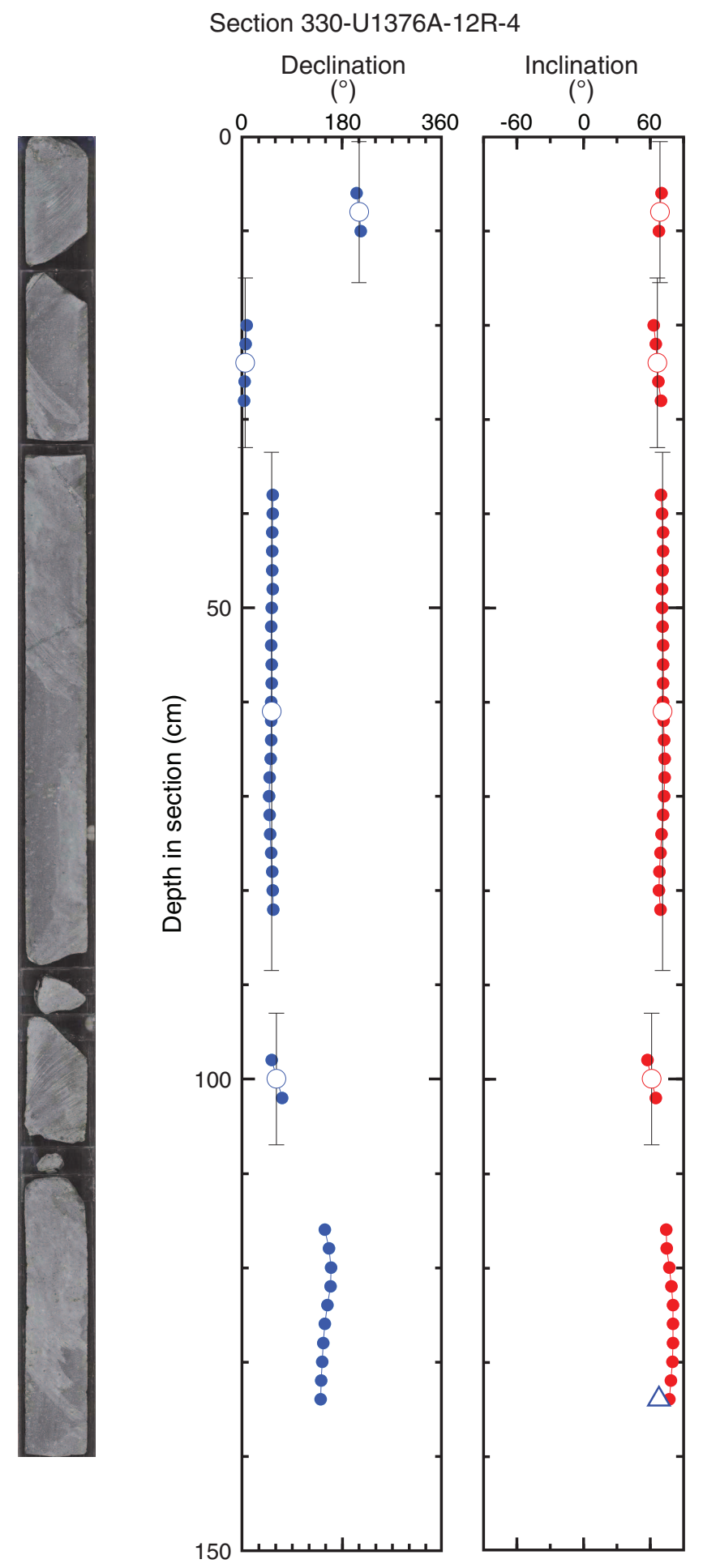


Figure F59. Representative Zijderveld plots of stepwise AF (left) and thermal (right) demagnetization results from adjacent discrete samples in Sections (A) 330-U1376A-5R-6 and (B) 330-U1376A-10R-2. Solid and open circles indicate projections of vector endpoints onto the horizontal and vertical planes, respectively. Red arrows indicate the direction derived from principal component analysis. NRM = natural remanent magnetization.

A

Sample 330-U1376A-5R-6, 77-79 cm

Vesicular pillow basalt

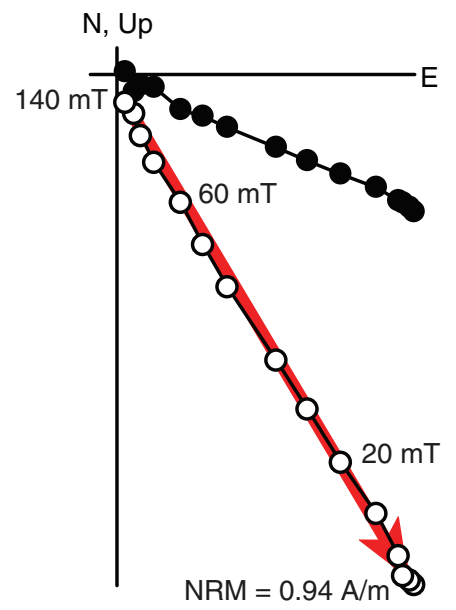

B

Sample 330-U1376A-10R-2, 94-96 cm Massive basalt

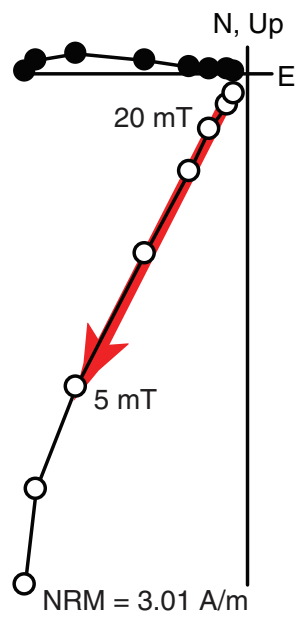

Sample 330-U1376A-5R-6, 82-84 cm

Vesicular pillow basalt

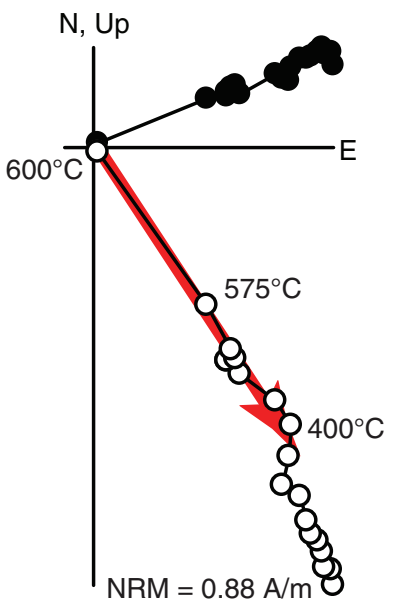

Sample 330-U1376A-10R-2, 92-94 cm Massive basalt

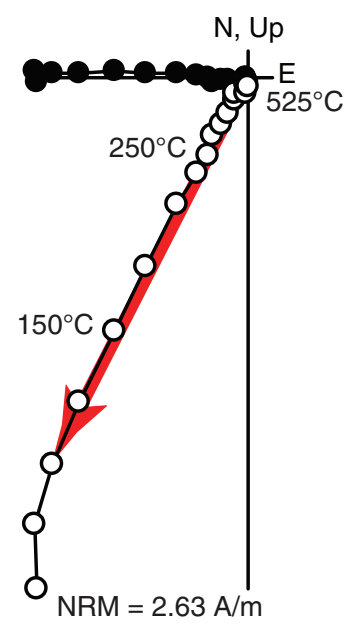


Figure F60. Plots of downhole logs and log unit divisions, Hole U1376A. A. Gamma ray (pass $1=$ triple combo first uphole pass, pass $2=$ triple combo repeat control pass) and caliper. B. Density (pass $1=$ triple combo first uphole pass, pass $2=$ triple combo repeat control pass, open circles $=$ onboard moisture and density [MAD] measurements on discrete samples, plotted in mbsf). C. Resistivity (IMPH = medium induction phasor-processed resistivity, IDPH = deep induction phasor-processed resistivity).

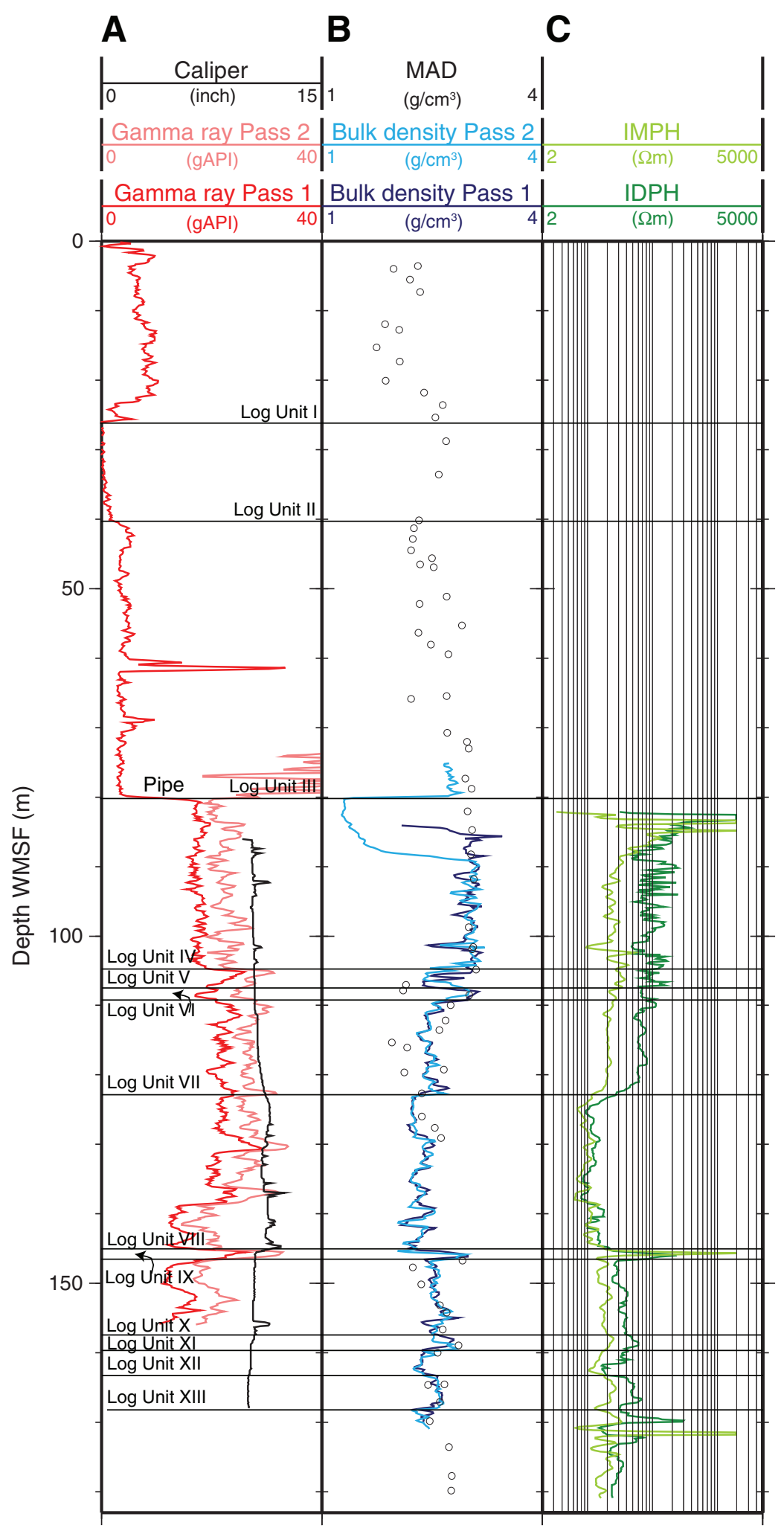


Figure F61. Comparison of raw magnetic field vertical-component data (not corrected for tool inclination) from the Göttingen Borehole Magnetometer with lithology, Hole U1376A. See Figure F50 for explanation of lithology and stratigraphic units.

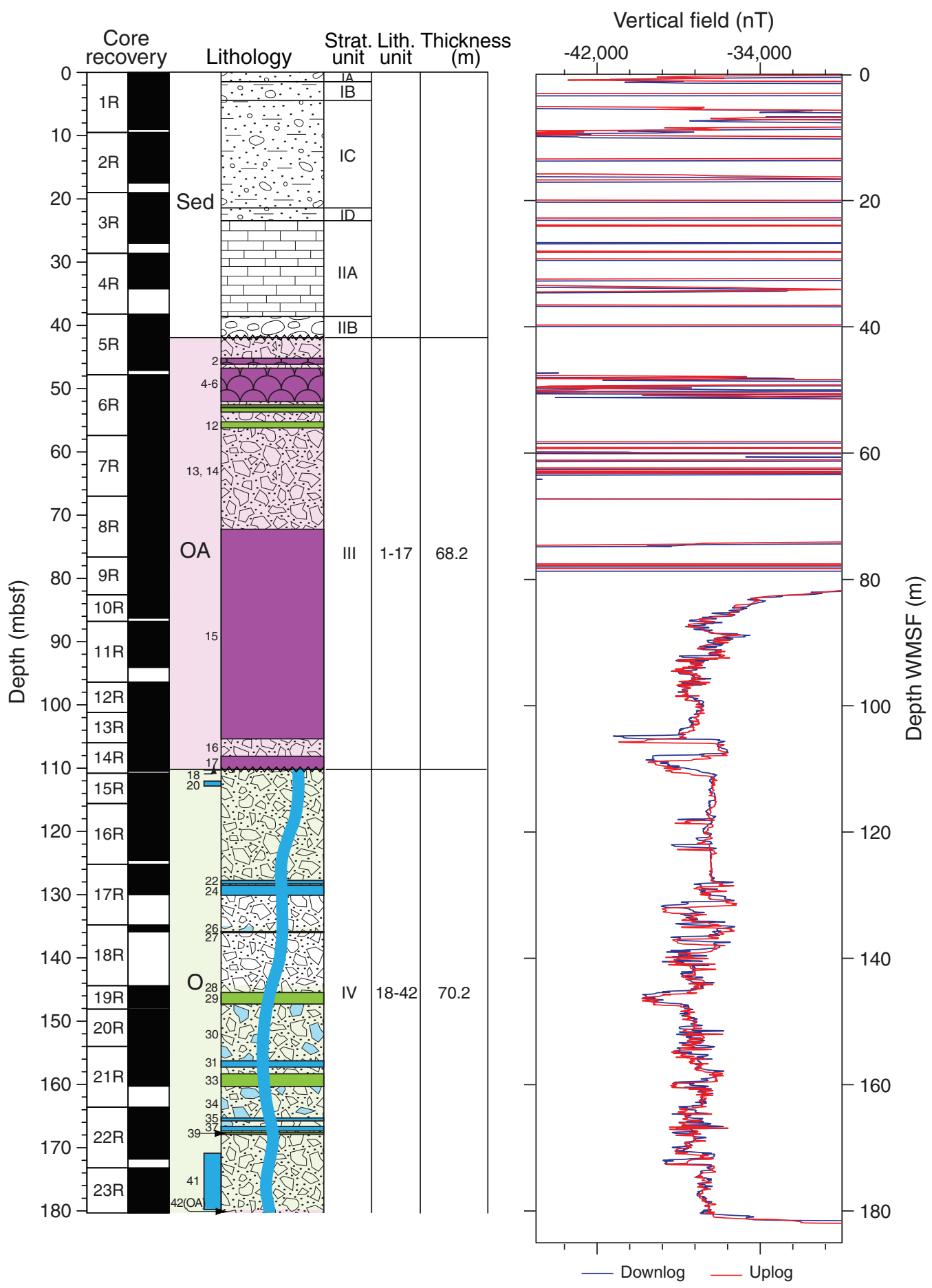


Figure F62. Detailed bathymetric map of Site U1377 on Hadar Guyot. GMT-generated bathymetric map is based on a combination of SIMRAD EM120 multibeam data collected during the AMAT02RR site survey expedition aboard the R/V Roger Revelle and global predicted bathymetry (v8.2) from Smith and Sandwell (1997). A single dredge location from a previous site survey cruise is indicated by an open square. Crossing multichannel seismic reflection lines collected during the AMAT02RR site survey are shown in blue (for details see Koppers et al., 2010). Map uses a linear projection (i.e., horizontal and vertical scales differ) based on WGS-84.

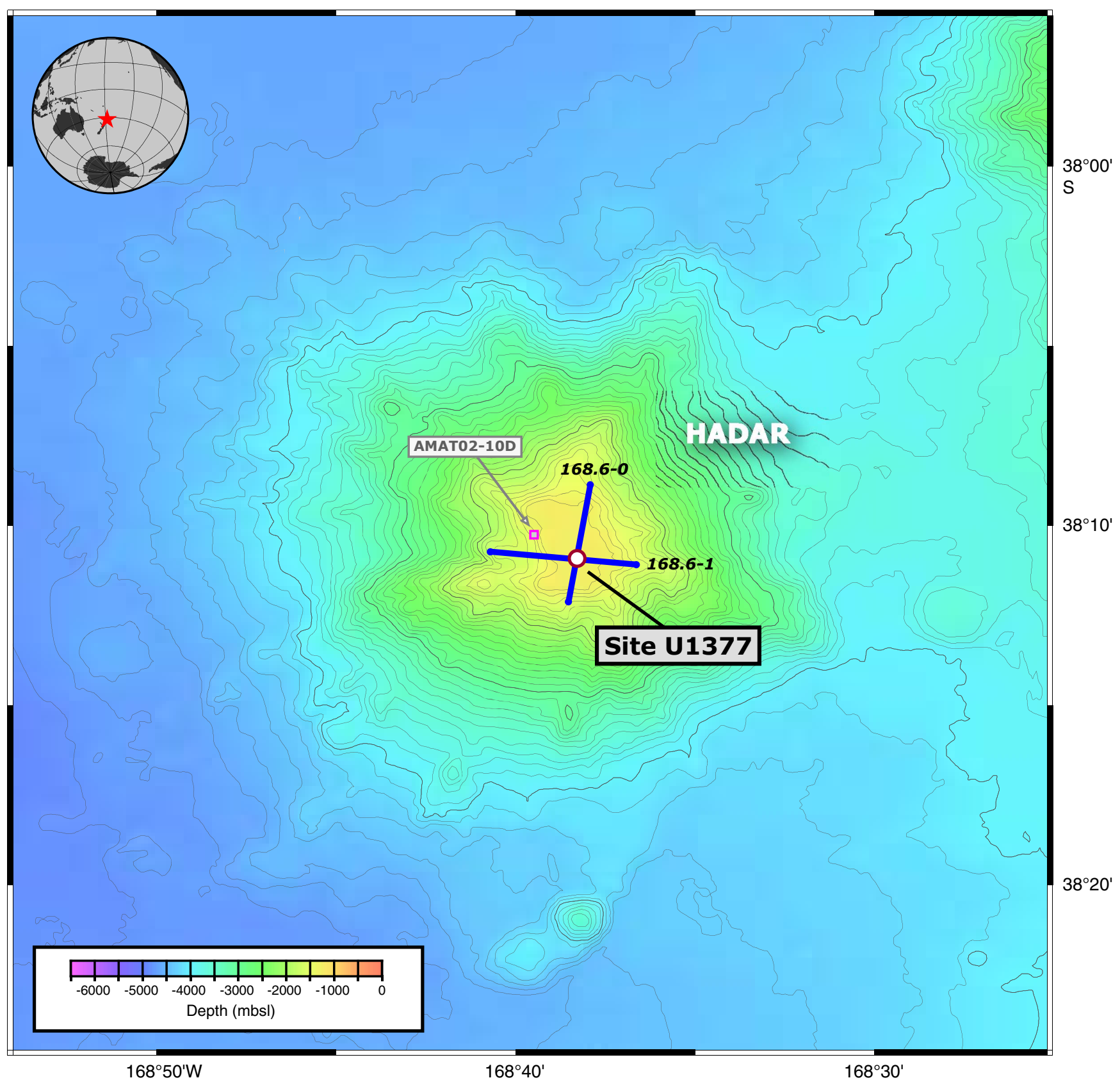


Figure F63. Stratigraphic summary, Site U1377. A. Sedimentary sequences. B. Lithology and volcanological features of igneous sequences.
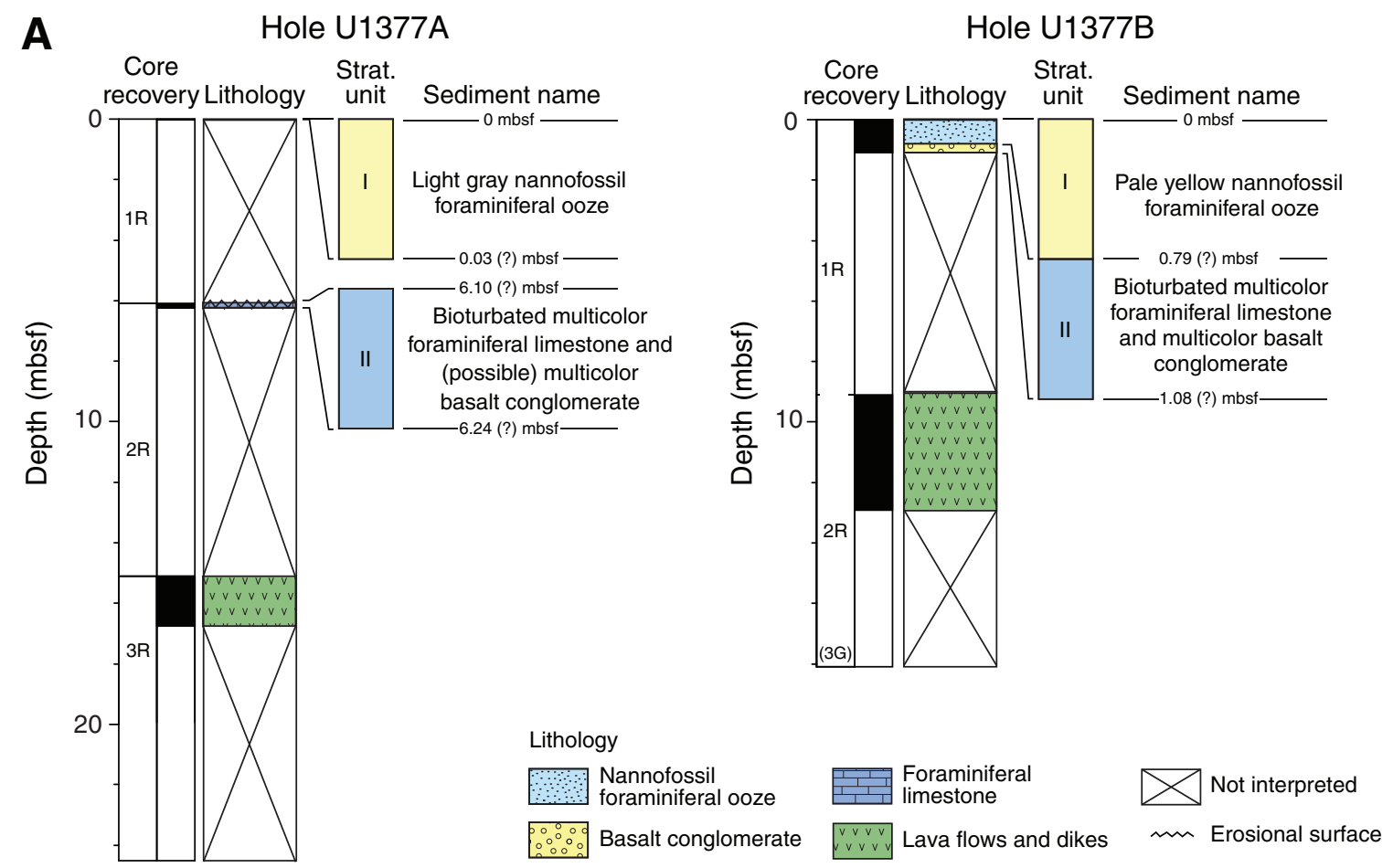

B
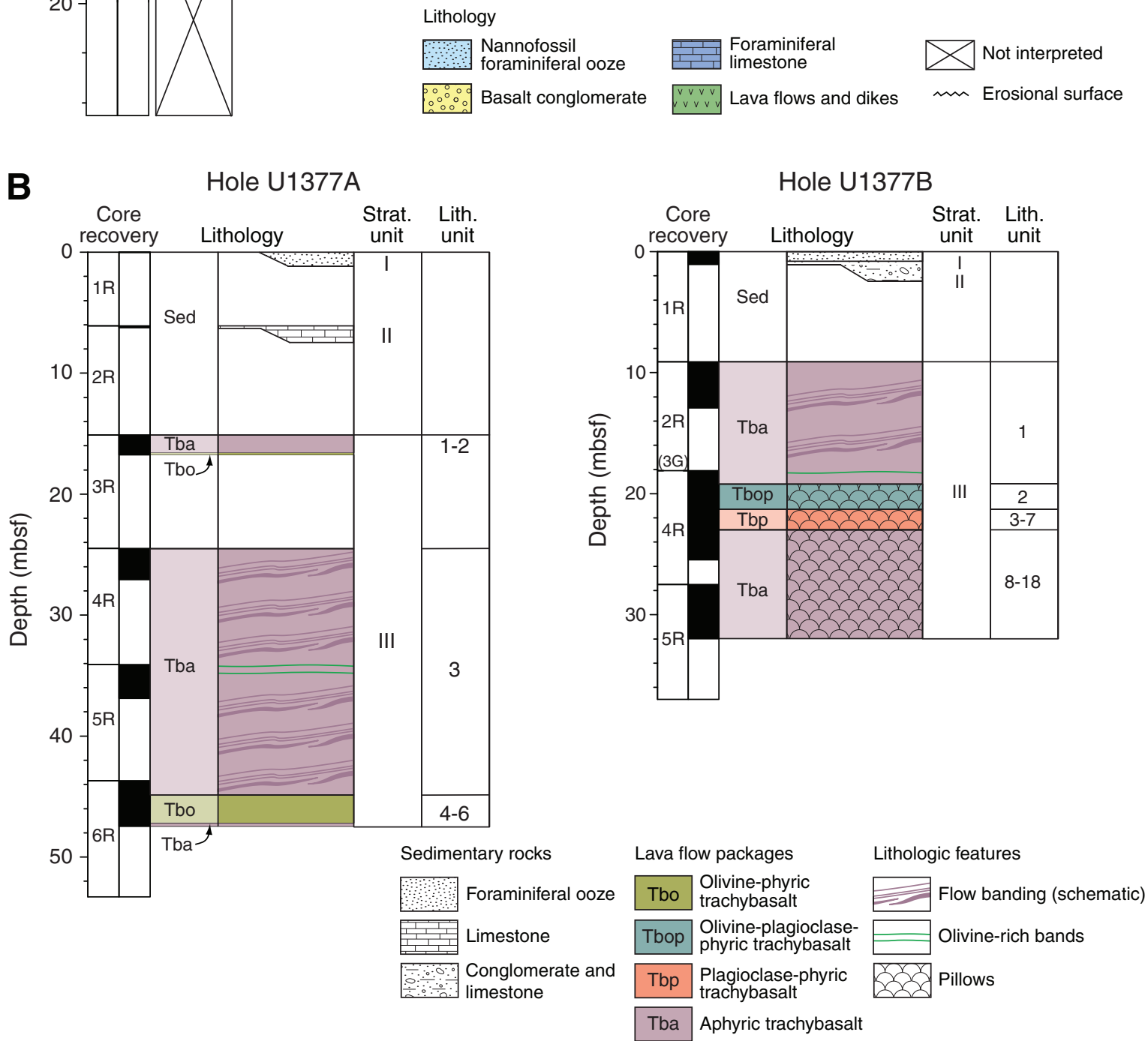
Figure F64. Scanned core images of representative lithologies, Site U1377. A. Foraminiferal limestone with ferromanganese-phosphate encrustation in stratigraphic Unit II (interval 330-U1377A-2R-1, 0-17 cm). B. Flow banding in trachybasalt of lithologic Unit 3 (interval 330-U1377A-4R-2, 63-77 cm). C. Flow banding in trachybasalt of lithologic Unit 1 (interval 330-U1377B-2R-2, 77-94 cm). D. Scanned core image (left) and interpretation (right) showing contacts between lithologic Units 2, 3, and 4 (interval 330-U1377B-4R-3, 102-140 cm). Lithologic Units 2 and 4 are pillows with glassy margins. Lithologic Unit 3 also has glassy margins and appears to have intruded into the space between Units 2 and 4.
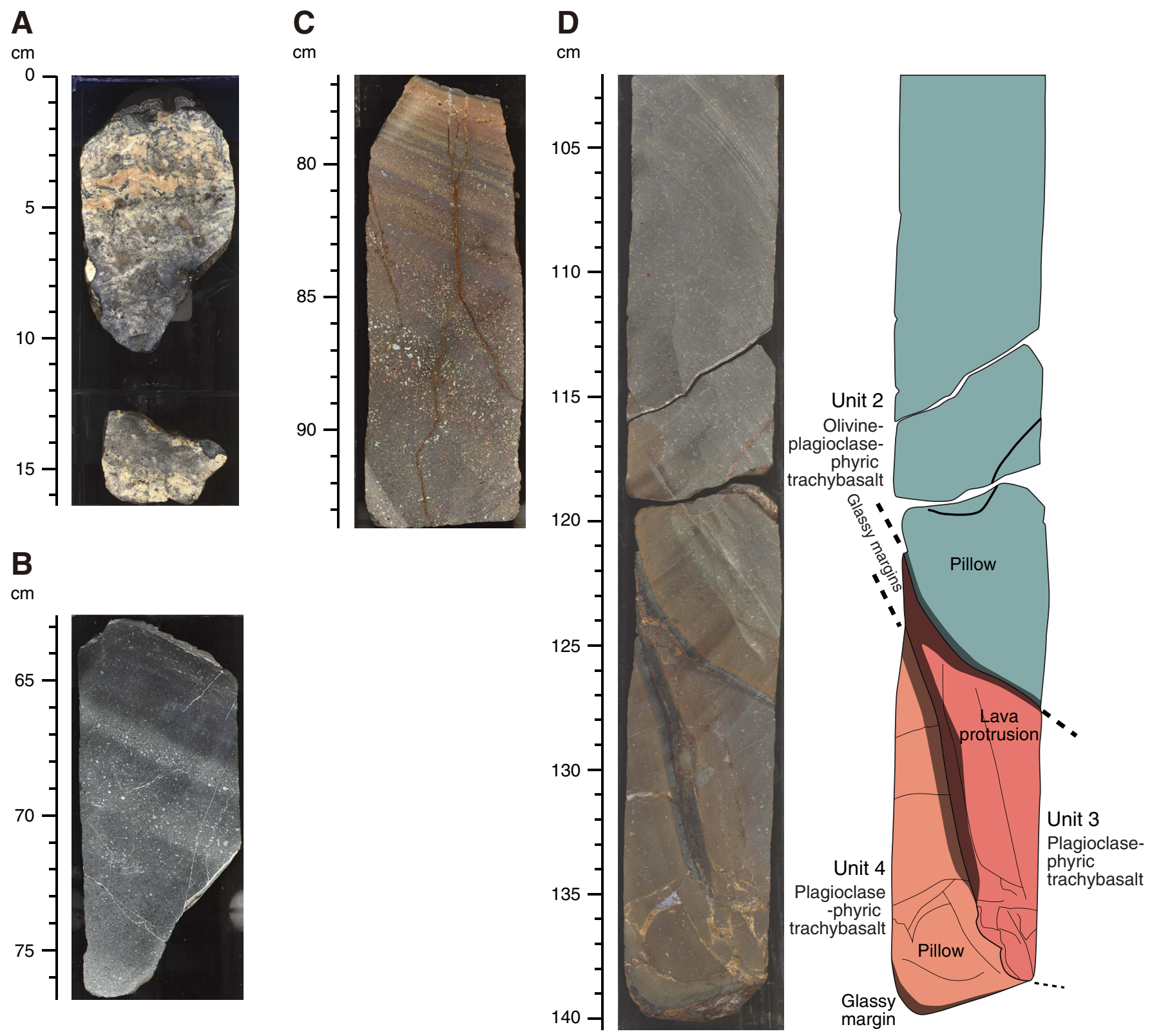
Figure F65. Thin section photomicrographs of planktonic foraminifers, Site U1377. A. Globigerinatheka sp. (Sample 330-U1377A-2R-1, 15-17cm; Thin Section 269). B. Acarina sp. (Sample 330-U1377B-1R-2, 8-12 cm; Thin Section 276). Both are under transmitted light.

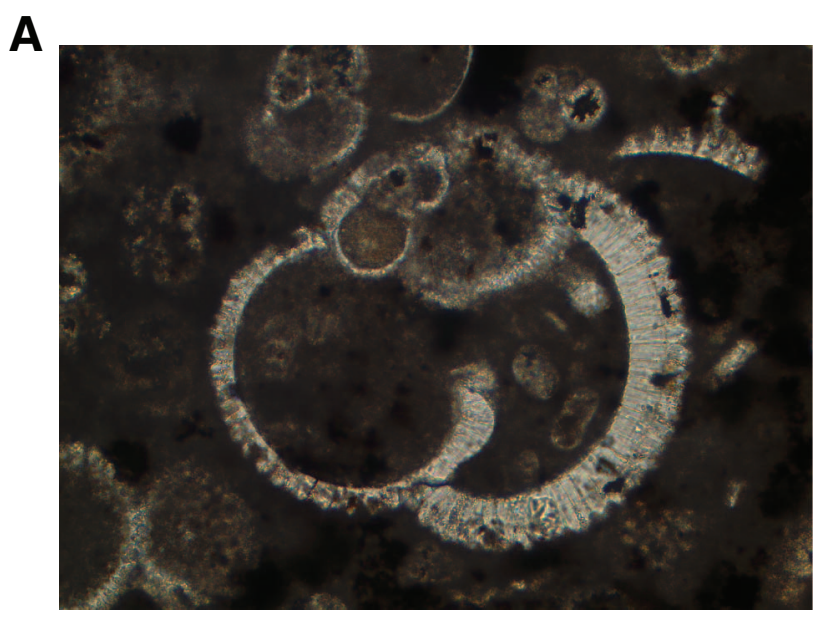

$100 \mu \mathrm{m}$

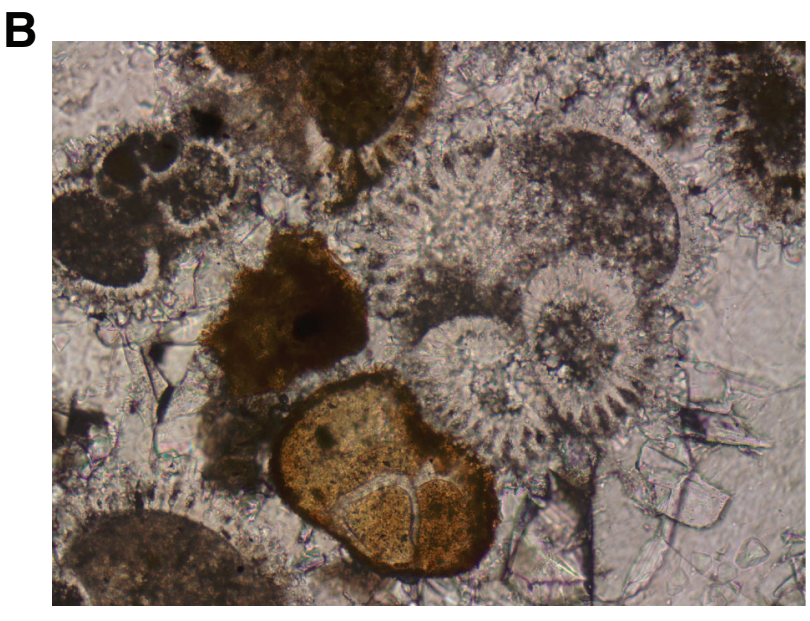

$100 \mu \mathrm{m}$ 
Figure F66. Thin section photomicrographs of altered olivine and groundmass. A. Phenocryst of olivine completely altered to green clay (outer part) and calcite in moderately olivine-phyric lava lobe. (Sample 330U1377A-6R-2, 64-66 cm; Thin Section 275) (with crossed polars). B. Groundmass highly altered to green and brown clay and slightly altered phenocrysts of plagioclase in aphyric basalt lava body or intrusive sheet (Sample 330-U1377A-3R-1, 68-70 cm; Thin Section 270) (with crossed polars). C. Vesicles (sparsely olivine-phyric lava lobe) filled with thin layer of brown clay at rim and later by white clay and carbonates (Sample 330-U1377A6R-2, 13-15 cm; Thin Section 274) (with crossed polars). D. Vuggy vein filled with mix of clay minerals, Fe oxyhydroxides, and goethite in aphyric basalt lava body or intrusive sheet. (Sample 330-U1377A-3R-1, 68-70 cm; Thin Section 270) (plane-polarized light).

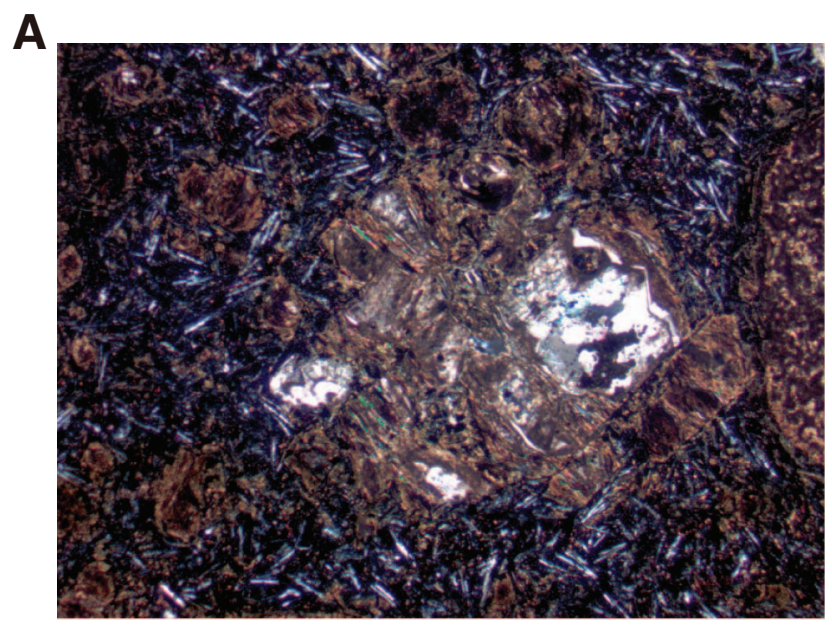

$1 \mathrm{~mm}$

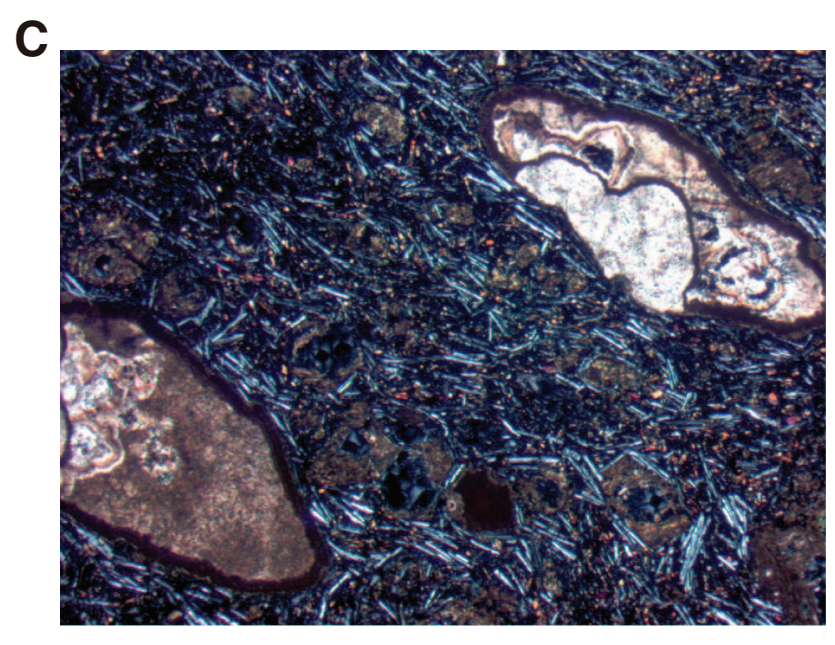

$1 \mathrm{~mm}$
B

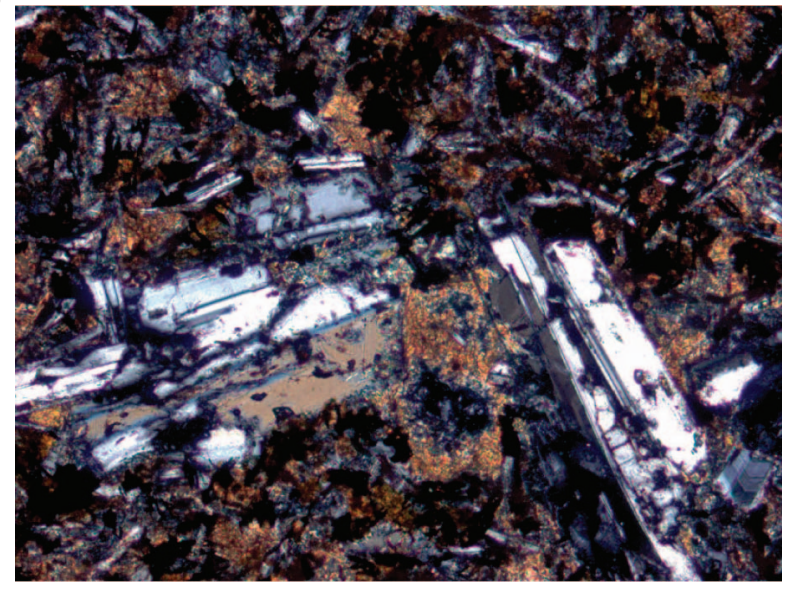

$1 \mathrm{~mm}$

D

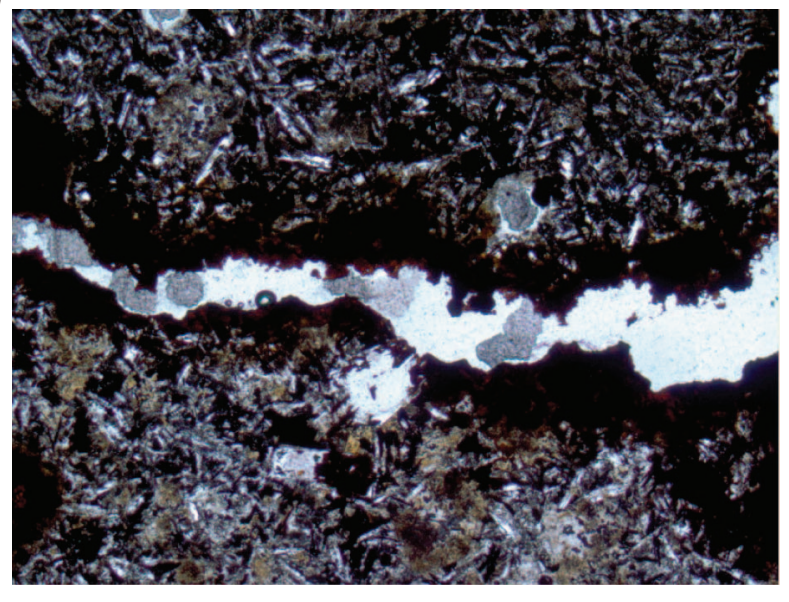

$1 \mathrm{~mm}$ 
Figure F67. Representative Zijderveld plots of stepwise alternating-field (left) and thermal (right) demagnetization results from adjacent discrete samples within Sections (A) 330-U1377A-5R-2 and (B) 330-U1377A-6R-1. Solid and open circles indicate projections of vector endpoints onto the horizontal and vertical planes, respectively. Red arrows indicate direction derived from principal component analysis. NRM = natural remanent magnetization.

A Sample 330-U1377A-5R-2, 94-96 cm Lava lobe or pillow

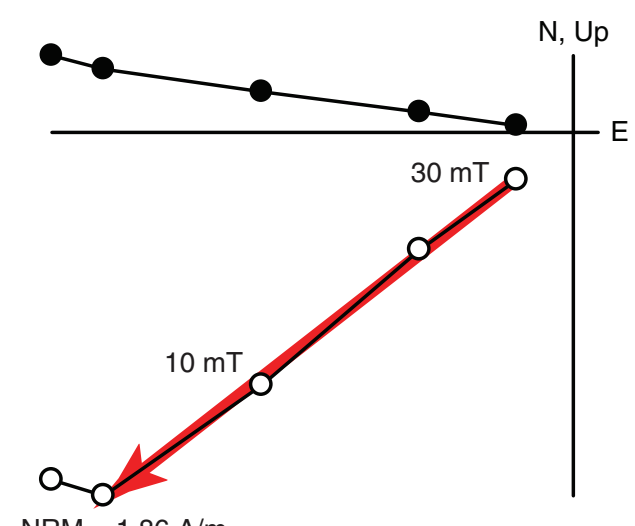

$\mathrm{NRM}=1.86 \mathrm{~A} / \mathrm{m}$

B

Sample 330-U1377A-6R-1, 49-51 cm Lava lobe or pillow

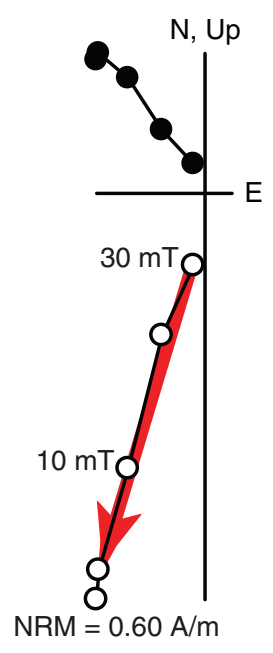

Sample 330-U1377A-5R-2, 96-98 cm Lava lobe or pillow

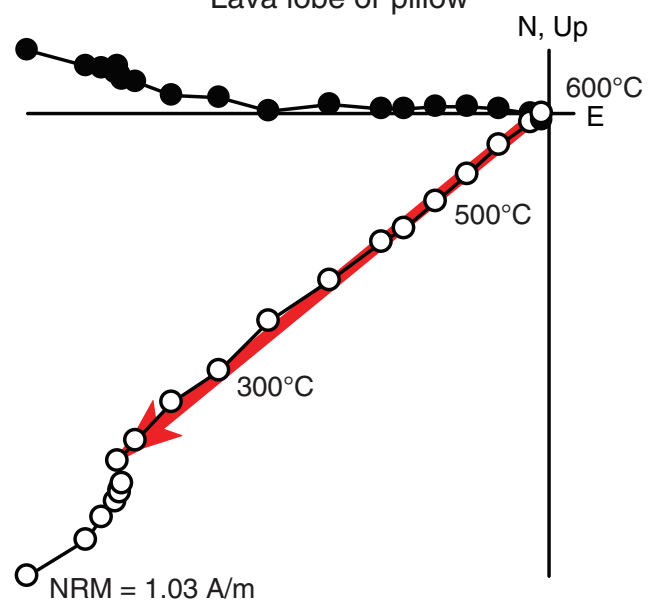

Sample 330-U1377A-6R-1, 51-53 cm Lava lobe or pillow

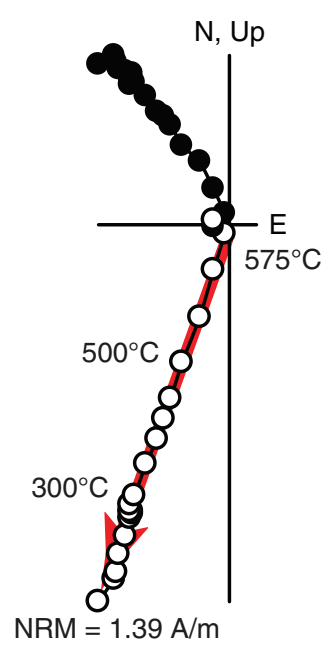


Table T1. Primary drill sites, Expedition 330.

\begin{tabular}{|c|c|c|c|c|c|c|c|c|c|}
\hline Approved site & Drilled site & Seamount name & Latitude & Longitude & $\begin{array}{l}\text { Estimated age } \\
\text { (Ma) }\end{array}$ & $\begin{array}{l}\text { Depth } \\
\text { (mbsl) }\end{array}$ & $\begin{array}{l}\text { Pelagics } \\
\text { (m) }\end{array}$ & $\begin{array}{l}\text { Clastics } \\
(\mathrm{m})\end{array}$ & $\begin{array}{l}\text { Basement } \\
(\mathrm{m})\end{array}$ \\
\hline LOUI-1C & U1372 & Canopus Guyot $26.5^{\circ} \mathrm{S}$ & $26^{\circ} 29.60^{\prime} \mathrm{S}$ & $174^{\circ} 43.75^{\prime} \mathrm{W}$ & $75-77^{*}$ & 1950 & 15 & 40 & $>350$ \\
\hline LOUI-2B & U1375 & Achernar Guyot $33.7^{\circ} \mathrm{S}$ & $33^{\circ} 41.90^{\prime} \mathrm{S}$ & $171^{\circ} 26.94^{\prime} \mathrm{W}$ & $58.5^{\dagger}$ & 1259 & 15 & 44 & $>350$ \\
\hline LOUI-3B & & $36.9^{\circ} \mathrm{S}$ & $36^{\circ} 54.26^{\prime} \mathrm{S}$ & $169^{\circ} 47.91^{\prime} \mathrm{W}$ & $54^{*}$ & 982 & 10 & 55 & $>350$ \\
\hline LOUI-4B & U1376 & Hadar Guyot $168.6^{\circ} \mathrm{W}$ & $38^{\circ} 10.98^{\prime} \mathrm{S}$ & $168^{\circ} 38.26^{\prime} \mathrm{W}$ & $50.1^{\dagger}$ & 1248 & 8 & 52 & $>350$ \\
\hline
\end{tabular}

* = interpolated, $\dagger=$ new ${ }^{40} \mathrm{Ar} /{ }^{39} \mathrm{Ar}$ age. All latitudes, longitudes, and water depths conform with data presented in the Expedition 330 Scientific Prospectus (see Koppers et al., 2010, for details). For actual drill site locations and water depths, refer to Table T3.

Table T2. Alternate drill sites, Expedition 330.

\begin{tabular}{|c|c|c|c|c|c|c|c|c|c|}
\hline $\begin{array}{l}\text { Approved } \\
\text { site }\end{array}$ & $\begin{array}{l}\text { Drilled } \\
\text { site }\end{array}$ & Seamount name & Latitude & Longitude & $\begin{array}{c}\text { Estimated age } \\
\text { (Ma) }\end{array}$ & $\begin{array}{l}\text { Depth } \\
\text { (mbsl) }\end{array}$ & $\begin{array}{l}\text { Pelagics } \\
\text { (m) }\end{array}$ & $\begin{array}{l}\text { Clastics } \\
(\mathrm{m})\end{array}$ & $\begin{array}{l}\text { Basement } \\
(\mathrm{m})\end{array}$ \\
\hline LOUI-1B & & Canopus Guyot $26.5^{\circ} \mathrm{S}$ & $26^{\circ} 28.66^{\prime} \mathrm{S}$ & $174^{\circ} 43.46^{\prime} \mathrm{W}$ & $75-77^{*}$ & 1840 & 10 & 40 & $>350$ \\
\hline LOUI-6A & U1373 & Rigil Guyot $28.6^{\circ} \mathrm{S}$ & $28^{\circ} 33.93^{\prime} \mathrm{S}$ & $173^{\circ} 16.78^{\prime} \mathrm{W}$ & $72-73^{*}$ & 1440 & 10 & 110 & $>350$ \\
\hline LOUI-6B & U1374 & Rigil Guyot $28.6^{\circ} \mathrm{S}$ & $28^{\circ} 35.75^{\prime} \mathrm{S}$ & $173^{\circ} 22.83^{\prime} \mathrm{W}$ & $72-73^{*}$ & 1545 & 10 & 110 & $>350$ \\
\hline LOUI-7A & & $32.3^{\circ} \mathrm{S}$ & $32^{\circ} 12.99^{\prime} \mathrm{S}$ & $171^{\circ} 52.84^{\prime} \mathrm{W}$ & $64^{*}$ & 1550 & 10 & 110 & $>350$ \\
\hline LOUI-7B & & $32.3^{\circ} \mathrm{S}$ & $32^{\circ} 13.44^{\prime} \mathrm{S}$ & $171^{\circ} 53.87^{\prime} \mathrm{W}$ & $64^{*}$ & 1560 & 10 & 110 & $>350$ \\
\hline LOUI-8A & & $36.9^{\circ} \mathrm{S}$ & $36^{\circ} 54.31^{\prime} \mathrm{S}$ & $169^{\circ} 47.91^{\prime} \mathrm{W}$ & $54^{*}$ & 970 & 40 & 80 & $>350$ \\
\hline LOUI-8B & & $36.9^{\circ} \mathrm{S}$ & $36^{\circ} 56.64^{\prime} \mathrm{S}$ & $169^{\circ} 45.76^{\prime} \mathrm{W}$ & $54^{*}$ & 960 & 50 & 80 & $>350$ \\
\hline LOUI-9A & & $168.3^{\circ} \mathrm{W}$ & $37^{\circ} 59.72^{\prime} \mathrm{S}$ & $168^{\circ} 17.11^{\prime} \mathrm{W}$ & $48-50^{\dagger}$ & 1150 & 10 & 105 & $>350$ \\
\hline
\end{tabular}

* = interpolated, $\dagger=$ new ${ }^{40} \mathrm{Ar} /{ }^{39} \mathrm{Ar}$ age, $\ddagger=$ site added and approved during Expedition 330. All latitudes, longitudes, and water depths conform with data presented in the Expedition 330 Scientific Prospectus (see Koppers et al., 2010, for details). For actual drill site locations and water depths, refer to Table T3. 
Table T3. Expedition 330 drilling operations.

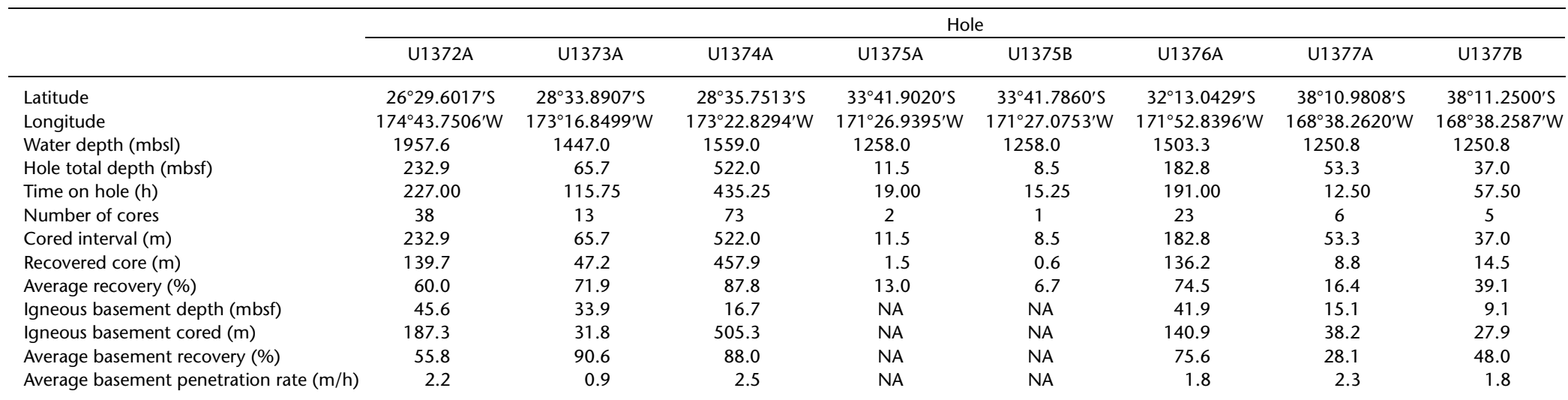

$\mathrm{NA}=$ not applicable 